\author{
UNIVERSIDADE DE SÃO PAULO \\ FACULDADE DE FILOSOFIA, LETRAS E CIÊNCIAS HUMANAS \\ DEPARTAMENTO DE LINGÜÍSTICA \\ ÁREA DE CONCENTRAÇÃO: SEMIÓTICA E LINGÜÍSTICA GERAL
}

\title{
PROCESSOS SEMIÓTICOS DA CONSTRUÇÃO DO SENTIDO NO ENSINO-APRENDIZAGEM \\ DA LÍNGUA INGLESA
}

Ana Claudia Marra

Tese apresentada na Área de
Concentração de Semiótica e
Lingüística Geral do Departamento de
Lingüística da Faculdade de Filosofia,
Letras e Ciências Humanas da
Universidade de São Paulo, para a
obtenção do título de Doutor em
Lingüística.

Orientador: Prof. Dr. Cidmar Teodoro Pais

São Paulo

2007 
BANCA EXAMINADORA 
Q Dedico, in memoriam, à minha mãe Qluiza B. Sharra que esteve sempre presente; uma participasãa ativa em minha educasão, me incentivando para que fosse em busca dos meus sonhos, de outros saberes, especialmente, em minha formasão artística e acadèmica. 
OSos meus mentores espirituais e terrenos, estes mostrando um caminho para os diversos saberes a serem sempre cullivados e aqueles por terem me inspirado no processo de amadurecimento das ideias contidas, neste trabalho. 


\section{AGRADECIMENTOS}

Cumpre agradecer, de modo especial, meu orientador e Professor Cidmar Teodoro Pais, que acreditou neste trabalho e percebeu que, de alguma maneira, as idéias nele contidas poderiam fazer diferença. Um educador que demonstra em cada gesto o quanto ama o que faz, notadamente, na formação de profissionais da área de lingüística e semiótica. Obrigada por ter visto algo a mais nesta pesquisa, sobremaneira, a postura sensível de um orientador com o seu orientando.

Ao colega de palco, grande artista Rogério Maia, que sempre acreditou em meu trabalho e me ajudou a dar o primeiro passo para a realização desta Tese. Parceiro de reflexão, sempre com uma palavra amiga e encorajadora para continuar minhas pesquisas de linguagem, neste contexto tão difícil em que está inserida a nossa cultura.

Aos professores Doutores Cidmar Teodoro Pais, Maria Aparecida Barbosa, Leny Magalhães Mrech, Débora Maria Befi Lopes e José Jeremias de Oliveira Filho, por terem dividido e dialogado comigo saberes tão diversos e relevantes para o processo de elaboração desta Tese.

Às professoras Doutoras Sandra Maria Silvia Palomo e Aurora de Jesus Rodrigues que participaram de minha banca de qualificação, sugerindo algumas considerações valiosas para a minha Tese, sobretudo incentivando-me a pensar sobre uma futura publicação.

Ao amigo Denis Canal Mendes que trouxe a este trabalho contribuições valorosas sobre a psicologia e a psique humana. Obrigada pelo estímulo, pelos ouvidos e voz amiga nos momentos mais difíceis desta minha trajetória.

Aos meus educandos que, indiretamente, colaboraram para a elaboração e concretização desta Tese, sem os quais não haveria um diálogo, apenas uma idéia. Thank you very much. 
"Mh, mas para se chegar à mudez, que grande esforso da vog. Minha vaz é a modo como vou buscar a realidade; a realidade, antes de minha linguagem, existia como um pensamento que não se pensa, mas por fatalidade fui e sou impelida a precisar saber a que o pensamento pensa. OA vealidade antecede a vaz que a procura, mas como a terra antecede a áruore, mas como o mundo antecede o homem, mas como o mar antecede a visáa do mar, a vida antecede o amor, a matéria do corpo antecede o corpo, e por sua vez a linguagem um dia terá antecedido a passe do silêncio.

EEu venho a medida do que designo - e este é o csplendor de se ter uma linguagem. Thas eu tenho muito mais à medida que nãa consigo designar. OA realidade é a matéria-prima, a linguagem é a modo como vou buscá-la - e como não acho. Shas é do buscar que nasce a que eu nã conhecia, e que instantaneamente reconheso. As linguagem é meu esforso humano. OPor destino tenho que ir buscar e por destino volto com as mãos vagias. MSas - volto com o indizúvel. O indizúvel só me paderá ser dado através do fracasso de minha linguagem. Ofó quando fallha a construsãa é que obtenho o que ela não conseguiu".

Glarisse Qlispector. "Apaixão segundo G.Y." 


\section{RESUMO}

MARRA, A.C. Processos semióticos da construção do sentido no ensinoaprendizagem da língua inglesa. 2007. 277 f. Tese (Doutorado). Faculdade de Filosofia, Letras e Ciências Humanas,Universidade de São Paulo, São Paulo,2007

Esta Tese situa-se na área de Semiótica e Lingüística Geral do Departamento de Lingüística da Faculdade de Filosofia, Letras e Ciências Humanas da Universidade de São Paulo. Tem por tema os processos semióticos da construção do sentido no ensino-aprendizagem da Língua Inglesa (L2) com vistas à interação educador-educando. Está fundamentada nos pressupostos teóricos da Semiótica Discursiva Greimasiana (1979), complementados por alguns aspectos da Psicanálise Lacaniana (1966), incluindo a teoria da comunicação de Jakobson (1969). A hipótese que orienta o estudo realizado considera que o discurso pedagógico viabiliza um modo de aplicação metodológico adequado às necessidades do educando adulto, bem como um olhar sensível às dificuldades encontradas, por ele, em seu processo de aquisição de uma língua estrangeira. Assim, tanto um quanto outro constroem percursos possíveis para chegarmos ao objeto de valor (Ov) dos sujeitos envolvidos nesse processo, em especial, o educando. O corpus desta pesquisa é constituído pela parte teórica, que sustenta a argumentação desta Tese, e pela parte observacional, que se refere à análise dos problemas do educando no processo de aquisição da L2. O procedimento metodológico adotado foi teórico-analítico e descritivo durante o processo de ensino-aprendizagem. Os passos seguidos, para esse procedimento, basearamse no modelo lingüístico-pedagógico, proposto pela pesquisadora: $1^{\text {a }}$ etapa entrevista (needs analysis), testes oral e escrito; $2^{\mathrm{a}}$ etapa - revisão dos conteúdos lingüísticos e exercícios escritos e orais; e $3^{a}$ etapa - desenvolvimento e aprofundamento dos conteúdos lingüísticos. O objetivo principal deste trabalho é contribuir para uma postura diferenciada na relação que se estabelece entre educador e educando, e os objetivos específicos são: 1) identificar sistemas de significação verbais, não verbais e sincréticos e verificar como se dá, nesses sistemas e no processo de enunciação, a conversão dos modelos mentais, em estruturas semióticas e sua manifestação em discurso; 2) buscar as possibilidades de aplicação desses processos ao ensino de língua inglesa para falantes do português como língua materna; e 3) examinar em que medida os modelos mentais e os processos de semiotização desses modelos podem ser transpostos para outra semiótica-objeto, em fase de aquisição de competência pelo mesmo sujeito. Os resultados obtidos indicaram que a hipótese foi adequada e os objetivos atingidos, satisfatoriamente. Além disso, os resultados provaram que o mal-estar do educando, advindo de um processo falho na interação entre educador e educando, na transmissão de um saber lingüístico, pode ser superado não só por um olhar sensível, mas também pela instauração de um processo de ensino-aprendizagem eficaz e adequado às necessidades do educando adulto.

Palavras-Chave: 1-Ensino-Aprendizagem; 2- Língua Inglesa; 3- Aquisição da L2; 4- Metodologia; 5- Semiótica 


\begin{abstract}
MARRA, A.C. Semiotical Processes of the Construction of Meaning in the Teaching-Learning of English Language. 2007. 277 p. Thesis (Doctoral). Faculdade de Filosofia, Letras e Ciências Humanas, Universidade de São Paulo, São Paulo,2007
\end{abstract}

This Thesis is set in the field of Semiotics and General Linguistics of the Department of Linguistics of Faculdade de Filosofia, Letras e Ciências Humanas da Universidade de São Paulo [School of Philosophy, Arts and Human Sciences of the University of São Paulo]. Its theme is the semiotical processes of the construction of meaning in the "teaching-learning" of English Language (L2) aiming at the "teacher-learner" interaction. It is based on the theoretical premises of Greimasian Discursive Semiotics (1979), supplemented by some aspects of the Lacanian Psychoanalysis (1966), including the communication theory of Jakobson (1969). The hypothesis that guides the accomplished studies considers that the pedagogical discourse enables a methodological way of application appropriated to the needs of the adult learner, as well as a sensitive look at the difficulties found by him/her in his/her acquisition process of a foreign language. Therefore, both teacher and learner create possible paths for us to get to the object of value (Ov) of the individuals involved in this process, especially the learner. The corpus of this research is constituted by the theoretical part, that supports the argumentation of this Thesis, and by the observational part, that refers to the analysis of the learner's problems, in the L2 acquisition process. The adopted methodological procedure was a theoretical analytical and descriptive one, during the process of "teaching-learning". The steps followed for this procedure were based on the linguistic pedagogical model proposed by the researcher: $1^{\text {st }}$ stage - interview (needs analysis), oral and written tests; $2^{\text {nd }}$ stage - review of the linguistic contents and oral and written exercises; and $3^{\text {rd }}$ stage - development and profound study of the linguistic contents. The main purpose of this project is to contribute to a different attitude in the relationship established between the teacher and the learner, and the specific purposes are: 1) to identify verbal, non-verbal and syncretic meaning systems and to verify how, in these systems and in the enunciation process, the conversion of mind models into semiotic structures and its manifestation into discourse happen; 2) to seek the possibilities of applying these processes to the teaching of English language for the speakers of Portuguese as the mother tongue; and 3) to study to what extent the mind models and the semiotization processes of such models can be transposed to another semiotic object, in the competence acquisition phase by the same individual. The results obtained showed that the hypothesis was appropriate and the purposes were satisfactorily reached. In addition, the results proved that the learner uneasiness, arising from an ineffective process of the interaction between the teacher and the learner in the transmission of the linguistic knowledge, can be overcome not only by a sensitive look, but also by the establishment of a "teaching-learning" process that is effective and appropriate to the needs of an adult learner.

Keywords:1 - Teaching-Learning; 2 - English Language; 3 - L2 acquisition; 4 Methodology; 5 - Semiotics. 


\section{ÍNDICE DE FIGURAS}

1- Níveis do Percurso Gerativo do Sentido.......................33

2- Quadrado Semiótico...........................................33

3- Esquema da Comunicação de Jakobson.......................73

4- Esquema Elementar do Processo de Comunicação............75

5- Signo lingüístico (Saussure e Hjelmslev) .....................79

6- Função semiótica aplicada ao ensino da L2 ...................84

7- Quadrado Semiótico - Ser vs Parecer......................154

8- Octógono semiótico do educando numa relação com o Objeto de Valor............................................156

9- Teoria dos Conjuntos: Educador e Educando................184

10-Percursos no Processo de Ensino-Aprendizagem: Educador e Educando................................................... 205

11- Aspectos das estruturas narrativas nas relações entre destinadores e destinatários e programas narrativos (Educador/Educando)...................................238

12- Octógono Semiótico da Competência e Capacitação de S1 no mercado de trabalho....................................245 


\section{SUMÁRIO}

INTRODUÇÃO

CAPÍTULO I .28

\section{I - FUNDAMENTAÇÃO TEÓRICA}

1.1 Aspectos da semiótica discursiva aplicados ao ensino de língua inglesa.

1.2 Aspectos da psicanálise lacaniana aplicados ao ensino de língua inglesa.

CAPÍTULO II

II - CONSIDERAÇÕES SOBRE A TEORIA DA LINGUAGEM

2.1 Uma breve reconstrução da aquisição de linguagem e do fenômeno lingüístico. 62

2.2 O processo da comunicação. .72

2.3 O ensino de língua estrangeira: breve histórico e aplicações metodológicas

CAPÍTULO III. 123

\section{III - CONSIDERAÇÕES ACERCA DO SABER}

3.1 Postura do educador na transmissão de um saber: implicações pedagógicas. 129

3.2 Relação do educando com o saber. 154

3.3 Relação com o domínio da cultura. 161

3.4 Considerações acerca do Sistema de Ensino de Língua Inglesa para 
adultos 168

3.5 Transmissão de um saber: mediação e motivação

3.6Transmissão e aquisição de um saber numa língua estrangeira.

CAPÍTULO IV 206

\section{LEVANTAMENTO E ANÁLISE DE DADOS}

4.1 Análise semiótica dos dados levantados. 237

4.2 Modelo semiótico da competência e capacitação do Educando no Mercado de trabalho 245

CAPÍTULO V. 247

PROPOSTA DE UM MODELO LINGÜÍSTICO-PEDAGÓGICO NO ENSINO DE LÍNGUA INGLESA

CONCLUSÃO 258

REFERÊNCIAS .270

REFERÊNCIA DE MATERIAIS ESPECIAIS ......................................276 REFERÊNCIA DE DOCUMENTOS ELETRÔNICOS...............................276

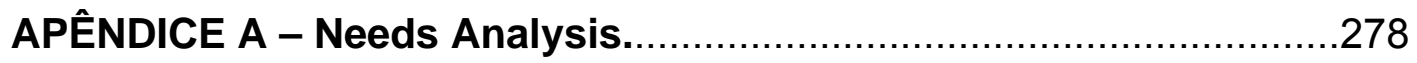

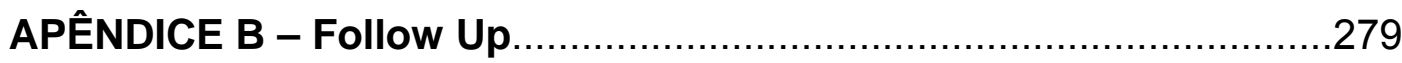

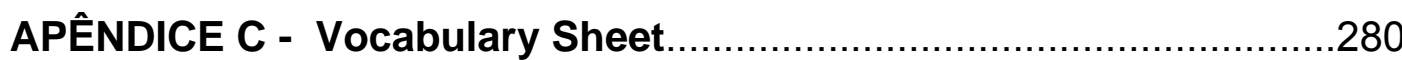

INTRODUÇÃO 
Esta Tese situa-se na área de concentração de Semiótica e Lingüística Geral do Departamento de Lingüística da Faculdade de Filosofia, Letras e Ciências Humanas da Universidade de São Paulo. Tem por tema os processos semióticos da construção do sentido no ensino-aprendizagem da Língua Inglesa com vistas à interação educador-educando, sendo que o tema proposto aponta para a complexidade no tratamento de significação da língua inglesa em uso, nos contextos sócio-cultural-comunicativoempresarial.

Essa complexidade advém, numa primeira instância, acerca da observação do mal-estar discente, devido a uma possível incompreensão das necessidades individuais.

$\mathrm{Na}$ fase inicial desta investigação, verificamos que os processos de construção de sentido para a aquisição de uma língua estrangeira não era eficiente para alguns discentes, uma vez que tanto o percurso metodológico quanto o de aprendizagem são relevantes para uma construção significativa da língua inglesa.

Nesse sentido, delimitamos a pesquisa ao tratamento entre as relações dos sujeitos envolvidos no processo de ensino-aprendizagem. Com relação a esse tratamento, entendemos que deve haver um vínculo necessário entre educador e educando, que responde pela construção de sentido da língua a ser estudada, considerando o universo sóciolingüístico-cultural e histórico do indivíduo adulto.

Temos por pressuposto que o processo de ensino-aprendizagem se explica pela interação educador-educando para que se instaure uma aprendizagem eficiente. Por essa razão, propomos a Tese, segundo a qual 
o mal-estar do discente provém não apenas do fato de julgar-se incapaz, mas também pela exigência de um mercado de trabalho competitivo, além da busca de uma aprendizagem satisfatória às suas necessidades.

Os pressupostos teóricos e metodológicos desta pesquisa contemplaram o percurso gerativo de sentido da semiótica discursiva Greimasiana, complementados por uma leitura da psicanálise Lacaniana (semântica cognitiva), incluindo a teoria de comunicação de Jakobson, para que possamos entender a maneira pela qual a comunicação se instaura entre os indivíduos.

Na mesma linha de raciocínio, esta Tese foi orientada pela seguinte hipótese: o discurso pedagógico viabiliza um modo de aplicação metodológica adequada às necessidades do educando, bem como um 'olhar sensível'1 às dificuldades encontradas pelo educando em seu processo de aquisição de uma língua estrangeira. Assim, tanto um quanto o outro constroem percursos possíveis para chegarmos ao objeto de valor dos sujeitos envolvidos neste processo, em especial, o educando.

Esta Tese tem por objetivo principal contribuir para uma postura diferenciada na relação que se estabelece entre educador e educando, em busca de um modelo lingüístico-pedagógico individual e adequado para a construção do processo cognitivo do sujeito, na aquisição de uma língua estrangeira e, dessa maneira, possa ele concluir com sucesso um /podersaber-fazer/, em sua trajetória do "novo saber".

Quanto aos objetivos específicos, esta pesquisa propõe-se a:

1- identificar sistemas de significação verbais, não verbais e sincréticos e verificar como se dá, nesses sistemas e no processo de enunciação, a

Olhar sensível: expressão criada pela pesquisadora. 
conversão dos modelos mentais, em estruturas semióticas e sua manifestação em discurso;

2- buscar as possibilidades de aplicação desses processos ao ensino de língua inglesa para falantes do português como língua materna; e

3- examinar em que medida os modelos mentais e os processos de semiotização desses modelos podem ser transpostos para outra semióticaobjeto, em fase de aquisição de competência pelo mesmo sujeito.

Justificamos a escolha desse tema pelo fato de termos observado que havia um descontentamento do discente, de um modo geral, com relação à aprendizagem da língua inglesa e ao papel do docente, nesse processo, que envolve fatores psicológicos e metodológicos, fato que ocasionou desistências do curso, mudança de docentes, bem como um possível retorno, após um longo período de afastamento do curso.

Desde a conclusão da graduação em licenciatura plena e bacharelado, em tradução e interpretação (1992) na Faculdade IberoAmericana, já nos preocupávamos com o rumo que o ensino de línguas estava tomando. Durante o curso, fomos formando uma consciência mais amplificada do que seria ensinar e a maneira que o ensino de uma língua deveria ser tratado. Todavia, quando fizemos estágios em língua inglesa e portuguesa, em escolas particulares, estaduais e, até mesmo, em escolas de idiomas, causou-nos espanto a maneira pela qual a língua era ensinada, pois o real tratamento que aqueles docentes ofereciam aos seus educados, não condizia com o que aprendíamos em nossas aulas ou com a literatura que líamos. Com o passar do tempo, tivemos oportunidades de trabalhar com metodologias diversificadas, aplicadas ao ensino de língua inglesa, para estudantes brasileiros e para indivíduos de outras nacionalidades, participando ativamente de palestras, cursos e workshops de língua inglesa. 
Dos estudos teóricos, seguimos uma pesquisa de observação e experimentação que foram realizadas no Brasil e no exterior, viabilizando um levantamento de dados que contribuíram para a elaboração desta Tese. A partir de então, fomos em busca de um caminho em que pudéssemos não só analisar a forma como ministramos a aula, mas também encontrar uma maneira de fazer com que o educando pudesse se tornar mais ativo, em seu processo de aprendizagem. Assim, preocupados com a questão da aquisição de uma nova língua e o processo relacional entre o educando e seu educador, resolvemos analisar os decursos da aprendizagem em nossos próprios educandos.

O tema em questão pode, também, interessar às pessoas envolvidas com o ensino de língua estrangeira para adultos, em especial, aos que lecionam língua inglesa e que procuram tornar cognoscível um saber lingüístico durante uma relação de ensino-aprendizagem. Acreditamos que esta Tese seja de grande valia para aqueles que se preocupam em não apenas transferir conhecimento, mas entender esse processo e ir além, propiciando meios para que seu educando seja capaz de discernir, construir e produzir por si só, a partir do momento em que ele passe a compreender um novo código lingüístico, no decorrer da transmissão e constituição de um "novo saber", dentro do circuito relacional entre destinador-educador e destinatário-educando.

Como sempre, trabalhamos com linguagens distintas, tais como a música, a dança, o teatro e as línguas naturais (inglês e português para estrangeiros), resolvemos, então, agregar a esta pesquisa, as nossas vivências acerca dessas significações verbais, não verbais e sincréticas, como elementos mediadores, na transmissão de um saber, ou seja, a utilização de instrumentais variados que trouxessem informações outras, mais ricas, distintas das que o docente está acostumado a lidar no seu diaa-dia, em sala de aula. 
Os procedimentos metodológicos para esta Tese foram os seguintes:

1. método dedutivo-indutivo e o método qualitativo;

2. procedimento teórico-analítico e descritivo;

3. análise dos procedimentos da aula de língua inglesa e descrição das necessidades do educando;

4. leituras nas áreas de língua inglesa, lingüística geral e aplicada, semiótica greimasiana, psicanálise lacaniana e alguns textos científicos que sustentaram a argumentação desta Tese;

5. entrevistas, testes (oral e escrito), gravações, registros escritos dos educandos;

6. elaboração individual de planos de aula; e

7. aplicação de um modelo lingüístico-pedagógico.

O corpus desta pesquisa é constituído pela parte teórica e observacional. O corpus teórico compõe-se de textos selecionados para sustentar a argumentação; esses textos foram extraídos de livros, sites e artigos científicos sobre semiótica Greimasiana, psicanálise Lacaniana, pedagogia do ensino de línguas, psicolingüística e lingüística e encontramse relacionados na bibliografia deste trabalho.

Quanto ao corpus observacional, há uma análise com descrição dos problemas enfrentados pelo educando na aquisição e desenvolvimento de uma língua estrangeira. Assim, analisaremos o seu processo cognitivo durante o desenvolvimento lingüístico da L2 (língua inglesa), a partir dos saberes do educando, para compreendermos a maneira que ele depreende a língua de uma outra cultura. 
Analogamente, iremos analisar e discutir sobre 0 discurso pedagógico, que é fundamental no decorrer da transmissão e constituição de um "novo saber", dentro de um circuito relacional entre destinadoreducador e destinatário-educando.

A observação em sala de aula permitirá a descrição do comportamento do educando na aquisição da L2, além de podermos registrar as dificuldades encontradas no processo de ensino-aprendizagem, sobretudo, para o discente adulto que se depara com um novo idioma, o qual possui estruturas sintáticas, semânticas, morfológicas e fonológicas distintas do português do Brasil.

Após o levantamento dos problemas e/ou dificuldades, será feita uma análise e buscaremos possíveis abordagens de ensino, propondo ao educando meios para sanar tais dificuldades. Dessa forma, teremos um corpus observacional pautado em observações empíricas, portanto em dados que foram coletados, analisados e registrados durante o período em que os educandos estiveram sob a nossa tutela. São dados reais de sala de aula, do comportamento e produção dos educandos, nesse processo de aquisição da língua inglesa.

Os dados, que foram levantados no estágio inicial do curso e no decorrer do mesmo, auxiliarão na elaboração de planos de aula mais adequados às necessidades do educando ou de um grupo de educandos. Além disso, os registros escritos e orais (exercícios, testes e gravações), desses educandos, também, servirão de base para mensurar o progresso na aquisição da língua.

Os instrumentos utilizados para a coleta de dados foram, além das literaturas científicas, os registros escritos e orais do desenvolvimento cognitivo dos discentes, num período de cinco anos. Quanto ao registro escrito, temos os exercícios do educando, as nossas observações que 
foram realizadas ao longo desse processo com relação ao comportamento do sujeito-aluno e de sua relação com seu Objeto de Valor (Ov), mediante ao que era solicitado, além de analisarmos o desenvolvimento lingüístico que ele adquiriu de seu maior ou menor envolvimento nesse processo. Da mesma forma, foram colhidos os registros orais, por meio de gravações de som e imagem do educando (individuais e grupos), que nos ajudaram a mensurar o grau de aquisição da L2 e serviram de referência para o próprio sujeito-aluno, visto que ele teria a oportunidade de reconhecer suas dificuldades na L2 e observar seu desenvolvimento lingüístico.

Os dados de cada indivíduo foram devidamente separados e analisados para que pudéssemos ter um perfil de seu desenvolvimento no período em que ele esteve sob nossa tutela. Ao final de cada estágio, foi solicitado ao educando que avaliasse seu próprio processo, descrevendo, sobretudo, seu olhar a respeito da língua inglesa e comparando o momento atual com o que havia vivenciado no passado na aprendizagem da L2.

Os educandos recebem uma planilha de acompanhamento (Follow Up) trimestralmente e são dadas pontuações nos seguintes itens: Reading, Writing, Listening, Pronunciation, Fluency, Grammar, Vocabulary, Homework, Written Test Grade, Oral Test Grade, On Going Process, General Interest e Frequency, cujos conceitos são discutidos com o educando para sabermos se ele concorda ou discorda da avaliação. O sistema adotado para avaliação além de ser "on going", ou seja, processo de avaliação continuada do discente, terá também a aplicação de um teste escrito e uma redação, um listening (material de áudio) e um teste oral (apresentação da leitura de um livro ou de um texto selecionado pelo educando ou educador). A planilha de acompanhamento é dada também ao departamento de Recursos Humanos $(\mathrm{RH})$ da empresa, quando for solicitada uma avaliação do progresso de seu funcionário, uma vez que, em muitos casos, é a própria empresa que paga o curso de língua inglesa, 
dessa forma, a empresa acompanha o desempenho e aproveitamento desse funcionário.

Os sujeitos selecionados para esta pesquisa são indivíduos que fizeram o curso de inglês (aulas individuais e em pequenos grupos) e estiveram sob nossa responsabilidade e orientação durante o período de 2001 a 2006. Consideramos tanto os educandos da escola de idiomas, onde trabalhamos, quanto os nossos educandos das aulas particulares que são o objeto de estudo principal desta pesquisa. Convém ressaltar que a metodologia da escola de idiomas é diferenciada da que é proposta para os educandos de aulas particulares, que seguem o modelo lingüísticopedagógico proposto pela pesquisadora desta Tese.

Esses sujeitos estão entre a idade de 27 e 56 anos e alguns deles começaram desde o nível elementar, outros apenas revisaram o nível básico e começaram no nível pré-intermediário, dando prosseguimento aos seus estudos em língua inglesa. Os sujeitos observados e analisados já haviam tido alguma experiência anterior com a língua inglesa, em aulas particulares ou em escolas de idiomas. Consideramos, ainda, o fato de as pessoas já terem estudado um pouco de inglês no ensino médio e terem o português do Brasil como língua materna, além de trabalharem para grandes corporações nacionais e internacionais, na cidade de São Paulo. De maneira geral, o objetivo desses sujeitos é a aquisição de uma competência escrita e oral, sobretudo a última, para que possam comunicar-se com seus clientes ou para uma inserção no mercado ou melhores oportunidades de conseguir cargos elevados e, conseqüentemente, melhor colocação e salário na sua empresa.

Infelizmente alguns dos educandos que estavam sendo observados, para esta pesquisa, interromperam-na por razões diversas: falta de tempo ou recursos financeiros, problemas familiares, demissão ou transferências para outra filial da empresa à qual pertenciam. Embora não tenhamos 
podido continuar um estudo observacional longitudinal com esses sujeitos, foi possível levantarmos alguns dados pelo período em que ali permaneceram. Visamos, dessa forma, a um estudo qualitativo do processo de aquisição de uma língua, em indivíduos adultos, observando o comportamento desses sujeitos-alunos, diante de uma nova língua e mediante ao que era proposto pelo educador, atribuindo às sugestões um modo diferente de pensar e estudar a língua inglesa. De qualquer forma, apenas oito indivíduos (aulas particulares) têm sido objeto de observação e constatações empíricas do método proposto, com um alto grau de satisfação e desempenho lingüístico tanto do ponto de vista do educador quanto do educando, até este momento.

Durante o período desta pesquisa foram, também, observadas as relações de ensino-aprendizagem entre docente e discente da instituição da qual fazemos parte para que pudéssemos ampliar o nosso olhar sobre esse processo e, assim, fôssemos capazes de detectar os sintomas que são instaurados, durante esse processo e, conseqüentemente, acabam por levar a uma desmotivação e afastamento do discente. Todas as aulas desenvolvidas foram ministradas em língua inglesa, sem a intervenção da língua portuguesa; entretanto, em algumas ocasiões, houve a necessidade de explicações em português, que eram prontamente vertidas para o inglês, já que o discente deve familiarizar-se com a L2 e entender o sentido construído pela língua em estudo.

O primeiro contato com o sujeito-aluno sempre se inicia com uma entrevista em português, para que possamos levantar as possíveis dificuldades que o próprio discente reconheça ter e/ou precisar aprender e, posteriormente, são aplicados testes de proficiência escrita, oral e de percepção auditiva para elencarmos as dificuldades de ordem lingüística e identificarmos o nível do discente. 
Nesse sentido, optamos por uma entrevista semi-dirigida, com a finalidade de podermos levantar alguns dados sobre a pessoa com quem trabalhamos e, mais tarde, ajudar a construir um caminho possível e motivador para o educando estudar, pensar e articular a L2.

A partir dessa análise das necessidades (needs analysis), podemos trabalhar com assuntos que são interessantes para o discente e o que ele, provavelmente, irá precisar não só no trabalho, mas também em outras situações de comunicação.

Além disso, essa entrevista permite um conhecimento do educando, ou seja, compreender seu histórico sociocultural e, assim sendo, podemos prever a melhor maneira de lidar com ele naquele momento de sua aprendizagem, com seus valores, crenças e a maneira que ele se coloca perante a língua a ser aprendida. Essa entrevista auxilia no mapeamento do perfil desse educando, para uma aula mais personalizada, que atenda às reais necessidades e interesses do sujeito, motivando-o a se envolver cada vez mais, em seu próprio processo de aprendizagem.

As primeiras aulas foram gravadas (vídeo e áudio) para que pudéssemos observar, de maneira mais criteriosa, as necessidades do discente, seu comportamento corporal e sua fala. Com o passar do tempo, foram apenas gravadas as falas do discente para que ele pudesse se autoavaliar na produção oral. Convém lembrar que essas gravações foram guardadas para que, posteriormente, se o educando continuasse no curso, pudéssemos comparar e avaliar sua expressão oral do passado com a do presente.

A expressão escrita também foi importante nesse processo, pelo fato de os testes e exercícios escritos terem sido guardados para o levantamento de uma taxionomia de problemas e, posteriormente, 
comparados a outros novos exercícios, para a verificação da persistência ou não de falhas que haviam sido constatadas, anteriormente.

O livro didático contemplado para o curso de língua inglesa tem como abordagem principal a comunicação (Communicative Approach) na L2. Todavia, agregamos a esse material algumas lições dos livros de Business English, com assuntos relacionados ao conteúdo programático do curso a serem aplicados ao mundo dos negócios. Posteriormente, outros materiais, relevantes ao curso, são agregados ao processo de aprendizagem do educando, de acordo com seu desenvolvimento lingüístico ou problemas detectados, em particular artigos técnicos ou literários, pertinentes à profissão e/ou universos de interesse, para serem trabalhados em casa e discutidos em aula. O material audiovisual acompanha o procedimento metodológico para facilitar as necessidades específicas do educando.

Além disso, são propostas leituras de livros e/ou artigos para o discente. Também, são propostos temas relacionados a filmes ou assuntos de interesse do educando, incluindo alguns clássicos das literaturas inglesa e americana. Essas leituras estão no nível lingüístico do sujeito-aluno e são solicitadas mensalmente ou com intervalo de dois meses, dependendo da disponibilidade do mesmo. Ao final do prazo, para a leitura do livro, o educando deverá estar pronto para narrar, relatar ou expor o que foi lido, além de ter de entregar um resumo da leitura realizada e as palavras ou expressões desconhecidas, classificando-as em categorias. Todas as apresentações de leituras são gravadas e os resumos guardados para que possamos mensurar o progresso do educando e ele próprio avaliar seu desempenho, por meio do áudio.

Após a correção do discurso escrito e/ou falado, é realizado um feedback dos registros escritos e orais, sendo que os "erros" são discutidos com o educando, além de sugestões para solucioná-los. Geralmente, são solicitados exercícios do livro de gramática e sua aplicabilidade para que 
ele possa compreender e expressar-se de acordo com as regras gramaticais da L2. Se as dificuldades detectadas forem de ordem fonológica, serão necessários exercícios de pronúncia e um treino mais sistemático com o áudio do livro didático ou de outros materiais que amplifiquem e melhorem o listening, ou seja, a acuidade auditiva.

Convém ressaltar que essa acuidade é variável, por isso após um determinado período de tempo são solicitados, também, filmes por ele apreciados, com legendas em inglês, escolhendo algumas cenas para serem estudadas. Ainda dentro dessa proposta, temos um estudo criterioso do vocabulário e das expressões, sugerimos ao educando que assista novamente ao filme, mas sem legendas.

No que diz respeito aos cds-rom e às músicas, esses são materiais complementares e agradáveis no processo de aprendizagem; o primeiro por ser interativo e apresentar atividades diversificadas, além de estarem relacionados a alguns links na internet, contendo jogos ou testes e um material audiovisual no seu conteúdo programático; o segundo, por ser um material que diverte o educando, estimulando-o a querer entender as músicas por ele apreciadas.

O material citado acima é trabalhado anteriormente, em sala de aula, para que ele tenha um exemplo do como trabalhar sozinho, dando-lhe, assim, maior autonomia em seu processo. Estimulamos o discente a criar outras maneiras para trabalhar com o mesmo material e, até mesmo, ir em busca de outros meios para estudar a L2. Diante disso, solicitamos ao educando trazer as dúvidas que possam surgir, durante seu processo de aprendizagem, para discutirmos em aula. O material complementar é sempre coerente e consistente ao que está sendo estudado, além de ir ao encontro das necessidades do educando. 
Com o advento da internet, outro material complementar é inserido nas aulas, além dos links de língua inglesa que colaboram com o educando para o estudo on line com exercícios, textos ou testes, considerando, também, os chats on line que propiciam ao discente uma comunicação tanto no código escrito como no oral. O software utilizado pelos sujeitosalunos dessa pesquisa é o "Skype", um serviço de telefonia gratuita, utilizado em quase todos os países, via internet, e que permite comunicação de voz e vídeo entre os usuários. Esse programa possibilita uma comunicação entre usuários Skype, podendo ser utilizado tanto por meio de um microfone com fones de ouvido para conversar e ouvir o outro usuário quanto digitar o texto e ler na tela do computador o que a outra pessoa está digitando, além de opções de vídeo e conferências com participantes de um grupo.

Outra prática metodológica utilizada com os educandos são os encontros em lugares distintos de uma sala de aula como cafés, pubs, pinacotecas, restaurantes, dentre outros para que haja interação entre os sujeitos de turmas diferentes e possam reconhecer, no outro e em si mesmo, o seu próprio processo de aprendizagem, além de podermos ampliar questões relativas ao capital ou acervo cultural do indivíduo. (Cf. Bourdieu)

Assim como o código oral é importante, o código escrito deve ser considerado também para que o educando possa se comunicar por meio de emails, que é uma prática comum no mundo dos negócios. Dessa forma, pedimos a ele que escreva sobre os livros lidos, como foi comentado anteriormente, e escreva sobre textos ou filmes que foram lidos ou vistos. Propomos, ainda, que escreva emails para os colegas de seu grupo ou de outros e, esses emails são analisados e comentados, posteriormente. Entretanto, essa prática é sempre solicitada como tarefa, para que ele tenha tempo de pensar, estudar e analisar o que escreveu, 
trazendo, assim, um feedback na aula seguinte. Durante as aulas, ele desenvolverá apenas a prática oral e auditiva que é muito mais importante para a grande maioria dos discentes.

Desse modo, há uma ênfase maior no significante oral, isto é, percepções dos sons, cadeia de palavras, pronúncia, discurso na L2, listening, entre outros, que são planejados, anteriormente, de acordo com os problemas detectados nas aulas ou para as necessidades imediatas do educando.

Contudo, é importante que o educando saiba da diferença do significante oral e significante escrito, diferentes entre si, sobretudo se comparados com a língua portuguesa. O educando terá de praticar tanto a escrita como a leitura para conseguir chegar a um domínio da habilidade verbo-motora. Essa habilidade será mais bem desenvolvida por meio de pequenos ditados feitos pelo educador ou o próprio educando transcreve os diálogos do áudio de seu livro didático.

Diante disso, é importante sempre emparelhar segmentos fônicos com seus respectivos grafemas para que o educando adquira autonomia na discriminação tanto oral como escrita do ato comunicativo. Por existir uma ênfase maior no significante oral, o curso é ministrado em inglês; conseqüentemente, faz-se necessário a utilização de métodos e técnicas que propiciem ao educando entender o outro código lingüístico.

Logo, para que haja um suporte que vincule sentido ao que enunciamos em inglês, utilizamos imagens, encenações, ou seja, outras semióticas-objeto que chamaremos de 'elementos correlatos' ou 'significações correlatas'2 para que o educando construa um sentido daquilo que está escutando e, possa, assim, relacionar idéias ou conceitos

2 Elementos Correlatos ou Significações Correlatas: expressão criada pela pesquisadora. 
da L2 ao que foi explanado por meio de um material visual ou uma atividade encenada.

Os procedimentos para essa pesquisa visaram primeiramente leituras na área de ensino de língua inglesa, lingüística geral e aplicada, semiótica greimasiana e psicanálise lacaniana, bem como outros textos científicos que sustentaram a argumentação desta Tese e encontram-se citados ao final do trabalho.

As entrevistas, os testes, as gravações, os registros escritos dos educandos e a forma que procedemos com cada sujeito-aluno, além dos planos de aulas, foram devidamente guardados para que, posteriormente, servissem como contra ponto entre a fase inicial do curso e a atual. Dessa forma, poderíamos mensurar o desenvolvimento cognitivo do sujeito-aluno na L2, o qual será discutido com mais propriedade no Capítulo IV no item Levantamento e Análise de Dados.

A Tese será configurada por cinco capítulos, além desta introdução, assim teremos:

O primeiro capítulo discorrerá sobre a fundamentação teórica, dividida em: Aspectos da Semiótica Discursiva e Aspectos da Psicanálise Lacaniana aplicados ao ensino de língua inglesa, para que possamos entender o princípio da construção de sentido de uma língua estrangeira.

O segundo capítulo abordará a teoria da linguagem que será subdividida em três itens: Uma breve reconstrução da aquisição de linguagem e do fenômeno lingüístico; O processo da comunicação; e 0 ensino de língua estrangeira: breve histórico e aplicações metodológicas. Esse capítulo tem a finalidade de mostrar que o processo de ensinoaprendizagem necessita de uma comunicação efetiva para que a 
aprendizagem seja instaurada, assim como, métodos e técnicas que possam auxiliar, na construção de um saber em outra língua.

O terceiro capítulo tratará de questões relativas ao saber: A postura do educador na transmissão de um saber lingüístico e as implicações ocorridas, durante e após esse processo; a relação do educando com o saber lingüístico; relação do educando com o domínio da cultura; considerações acerca do sistema de ensino da língua inglesa para adultos, e ao final do capítulo, serão apresentadas questões relativas à transmissão do saber mediação e motivação; e a transmissão e aquisição de um saber numa língua estrangeira.

O quarto capítulo apresentará o corpus observacional, Levantamento e Análise dos Dados, que é a produção discursiva do educando e o comportamento do mesmo perante a L2. Pretendemos fazer uma análise a partir dos dados colhidos do corpus observacional, ou seja, do material levantado das entrevistas com os educandos e das observações das aulas, tendo como ponto de partida os problemas encontrados por eles durante a aquisição da língua inglesa. O quarto capítulo será dividido da seguinte maneira: Análise semiótica dos dados levantados e um modelo semiótico da competência e capacitação do educando num mercado de trabalho.

O quinto e último capítulo apresentará uma proposta de Modelo lingüístico-pedagógico para o ensino de língua inglesa que discorrerá sobre questões relativas ao processo de ensino-aprendizagem sob um outro olhar, uma outra possibilidade de desvendamento desse processo de transmissão de um saber, dentro de um contexto sócio-histórico-lingüístico e cultural em que se encontram os sujeitos envolvidos, no ato do processo de ensino-aprendizagem.

Segue-se a esses capítulos a parte final de nosso trabalho que apresentará a conclusão, a bibliografia e o apêndice. 


\section{CAPÍTULO I}

\section{I- FUNDAMENTAÇÃO TEÓRICA}

Hors du texte, point de salut. Tout le texte, rien
que le texte et rien hors du texte.

A.J . Greimas

Nós somos os produtores de nossos discursos e somos os resultados dos nossos discursos.

J acques Lacan

\subsection{Aspectos da semiótica discursiva aplicadas ao ensino de}

\section{língua inglesa}

O ponto de vista semiótico contemplado nesta Tese é da Escola de Paris, que tem como objeto de estudo a construção do sentido em todas as formas de manifestação discursiva. A teoria semiótica surge dentro de um projeto semiótico da escola de Paris com Greimas e Fontanille. A semiótica discursiva tem seu início nos anos 60 , é uma ferramenta metodológica usada para compreender a significação ou semiose em ato. Essa ciência da significação foi constituída num período que se convencionou denominar de "pré-estruturalista", tendo como continuadores das proposições de Hjelmlev (1943), A.J.Greimas e outros importantes seguidores como Rastier, Courtés, Coquet, Parret, Landowski, Pais, dentre outros.

Podemos dizer que a semiótica Greimasiana é uma teoria da significação ou uma teoria geral da linguagem, pois enfoca a construção de sentido nos diversos textos, sendo essa significação estudada à luz de três teorias: da fenomenologia de Merleau-Ponty sobre a relação do sujeito com 
o mundo que o rodeia (sentidos que são convocados nos textos), da lingüística de Hjelmslev (possibilidade de uma metalinguagem teórica) e da antropologia de Lévi-Strauss e Dumézil de cujas idéias Greimas compartilhava.

A semiótica é uma ciência que tem por objeto de investigação todas as linguagens possíveis, sendo elas verbais (artigos científicos, textos literários, etc.), não verbais (música, dança, pintura, escultura, etc.) ou sincréticas (teatro, filmes, ópera, etc.). Essa ciência define-se pela relação de pressuposição recíproca entre significante e significado, num jogo estabelecido entre forma de expressão e a forma de conteúdo, examinando a maneira pela qual um texto é construído, observando, desse modo, o fenômeno de produção de significação e de sentido.

A semiótica divide um texto em planos e níveis. Temos, portanto, um plano de expressão que vem a ser o meio em que comunicamos algo e um plano do conteúdo que é a maneira que comunicamos esse algo. No plano do conteúdo, encontramos os níveis fundamental, narrativo e discursivo. São essas estruturas gramaticais da semiótica discursiva, cada qual com seus componentes sintáticos e semânticos, que constroem a noção de percurso gerativo do sentido. A leitura semiótica procura conhecer a maneira que o sentido é construído ao olharmos uma determinada situação, pessoas, gestos, comportamentos, etc. Dessa forma, essa leitura estabelece um significado do objeto que se está estudando, analisando-o sob um novo ângulo.

Essa ciência é um instrumento para explicar e interpretar os discursos dos indivíduos na sociedade, observando alguns aspectos que não foram vislumbrados anteriormente ou ignorados pelos produtores dos discursos, mostrando, assim, suas origens e conseqüências ou efeitos desejados ou, ainda, algo que estava oculto, revelando aspectos mais sutis de um discurso ou texto; podemos, por meio dela, raciocinar analiticamente, 
ajudando a identificar ou reconstruir um texto, fazendo o caminho inverso da produção discursiva, preocupando-se em entender como o sentido é construído e, conseqüentemente, produzido. A partir de uma visão mais analítica, podemos entender melhor as operações mentais do indivíduo e, dessa maneira, seremos capazes de construir ou reconstruir a significação de um objeto de estudo, reorientando e nos levando a fazer perguntas certas e/ou escolher métodos mais eficazes. Interpretando os discursos dos indivíduos, podemos identificar e reconhecer os problemas nesses discursos, o que possibilitará melhor desenvolvimento argumentativo no processo discursivo.

Entendemos, assim, que a semiótica aplicada ao ensino de línguas procura compreender a maneira que o sentido é construído ao vivenciarmos situações do dia-a-dia do indivíduo, já que o objeto de investigação da semiótica são as diversas linguagens e o modo pelo qual elas se constituem num "texto" que é uma unidade de sentido, um espetáculo semiótico. Assim sendo, a semiótica busca, filtra, formaliza e define modos de exploração do conhecimento, auxiliando-nos em uma estratégia metodológica mais bem elaborada ao diagnosticar o perfil de nosso educando e suas produções discursivas na L2. Ao ensinarmos a L2, estamos mostrando a visão de mundo de uma cultura (saber sobre um mundo = episteme e cognição) para o educando, atribuindo um sentido a ela; cabe ao educador fazer com que essa visão de mundo faça sentido para o sujeito-aluno. Todavia, o educador precisa produzir uma significação para esse sujeito, bem como entender a maneira pela qual esse educando trabalha a L2 e a atualiza (alimentação e realimentação do sistema lingüístico), além de identificar os problemas que possam surgir durante esse processo de aprendizagem.

Sabemos que toda semiose precisará de outra ou outras semioses para produzir uma significação. Se tomarmos o ensino de língua 
estrangeira como sendo o "texto" a ser analisado, precisaremos usar as palavras para produzir uma semiose, uma significação. Contudo, essas palavras necessitam também de imagens, gestos e outras linguagens (semióticas-objeto) que agreguem um sentido para o que está sendo explicado e, dessa forma, possam produzir uma significação e um sentido. Ao utilizarmos apenas as palavras, ou seja, um discurso falado, restringimos as operações cognitivas do educando e acabamos por tornar a aula enfadonha, sobretudo se estivermos lidando com indivíduos em início de aprendizagem da língua inglesa.

As imagens são mais dinâmicas e acabam levando o sujeito-aluno a uma participação mais ativa e entusiasmada, pois exigem dele menos esforço para compreender a L2 durante a aula. Por outro lado, somente as palavras, ou seja, a explicação do educador acaba não sendo suficiente e, algumas vezes, o discurso pedagógico de alguns docentes é monocórdico, acarretando um maior esforço na compreensão e menor envolvimento do sujeito-aluno, conseqüentemente, um distanciamento e/ou falta de motivação pela aula.

Isso posto, a semiótica analisa o objeto: um "texto". Texto, numa acepção semiótica, tem um sentido mais amplo, não deve ser entendido apenas como um texto verbal. As manifestações textuais podem ser verbais, não verbais e sincréticas, ou seja, é qualquer objeto que signifique, como um quadro, uma poesia, um filme, uma música, uma aula, dentre outras linguagens. Uma narrativa é estabelecida nesse "texto" e essa narrativa pressupõe uma sucessão de estados e transformações desses estados para que seja cumprido um percurso. Além disso, é necessário que o sujeito, que faz parte dessa narrativa, adquira uma ou mais competências modais para realizar uma ação. Os valores modais são os seguintes: /querer/, /dever/, /poder/ e /saber/ e, por meio da análise 
semiótica, podemos notar essas modalizações no sujeito, durante o seu percurso.

Qualquer "texto" possui uma lógica que lhe é subjacente, isto é, existe uma organização que será comum a qualquer um desses "textos". A narrativa desse "texto" sempre trará consigo noções de sujeito, anti-sujeito e objeto de valor (Ov). O sujeito é aquele que vai em busca de seu objeto, que representa algo para ele, possuindo um valor. Esse objeto é o que o sujeito almeja, algo ou alguém que ele deseja alcançar. Esse sujeito possui a necessidade de ir ao encontro de seu objeto, portanto ele quer ou deseja entrar em conjunção com esse objeto de valor que podem ser eufóricos (valorizados positivamente) ou disfóricos (valorizados negativamente). As ações que acompanharemos, durante a construção dessa narrativa, é que sancionarão positiva ou negativamente esse objeto de valor, transformando esse percurso numa narrativa de vitória ou fracasso. Quando nos remetemos ao anti-sujeito, estamos falando de qualquer coisa que dificulte essa trajetória de busca, isto é, os obstáculos com que o sujeito se depara.

A organização de uma narrativa também utiliza outros conceitos como o de destinador, adjuvante, actante e ator. O destinador torna um sujeito competente para que ele possa ir em busca de seu objeto de valor, e esse destinador poderá utilizar-se de quadro tipos de manipulação, a saber, tentação, intimidação, sedução e provocação, que serão aceitas ou não pelo sujeito-destinatário. Desse modo, esse sujeito será dotado ou de um saber, ou de um dever, ou de um querer ou de um poder (valores modais) permitindo-Ihe agir em busca de sua meta. O adjuvante ajuda o sujeito a transpor os obstáculos nessa trajetória ou ajudará o anti-sujeito a colocar empecilhos na ação do sujeito, sendo um antiadjuvante do sujeito. $O$ sujeito, anti-sujeito e objeto de valor são actantes, uma vez que eles organizam a narrativa e, cujos papéis podem estar preenchidos de diferentes maneiras pela figura do ator. Esses conceitos estão dispostos 
numa organização hierárquica dividida em níveis: nível fundamental (nível mais profundo, mais abstrato e mais simples), nível narrativo (nível intermediário) e o nível discursivo (nível mais superficial, mais concreto e mais complexo). Os actantes estão no nível narrativo e os atores no nível discursivo. Então, teremos o seguinte diagrama:

\section{PLANO DE EXPRESSÃO}

(nível textual/manifestação)

\section{PLANO DO CONTEÚDO}

\begin{tabular}{|l|l|}
\multicolumn{2}{|c|}{ (imanente) } \\
\begin{tabular}{|l|l|} 
Nível Discursivo (estrutura \\
de superfície)
\end{tabular} & \multicolumn{1}{|c|}{ Atores } \\
\hline $\begin{array}{l}\text { Nível Narrativo (estrutura } \\
\text { intermediária) }\end{array}$ & $\begin{array}{l}\text { Actantes (sujeito, } \\
\text { objeto, destinador, } \\
\text { destinatário, adjuvante, } \\
\text { oponente) }\end{array}$ \\
\hline $\begin{array}{l}\text { Nível Fundamental } \\
\text { (estrutura profunda) }\end{array}$ & $\begin{array}{l}\text { Oposições Semânticas } \\
\text { (quadrado semiótico) }\end{array}$ \\
\hline
\end{tabular}

Figura 1: Níveis do percurso gerativo do sentido

O quadrado semiótico pertence ao nível fundamental e, nesse nível, podemos observar os elementos contraditórios e complementares (as oposições semânticas). Temos então:

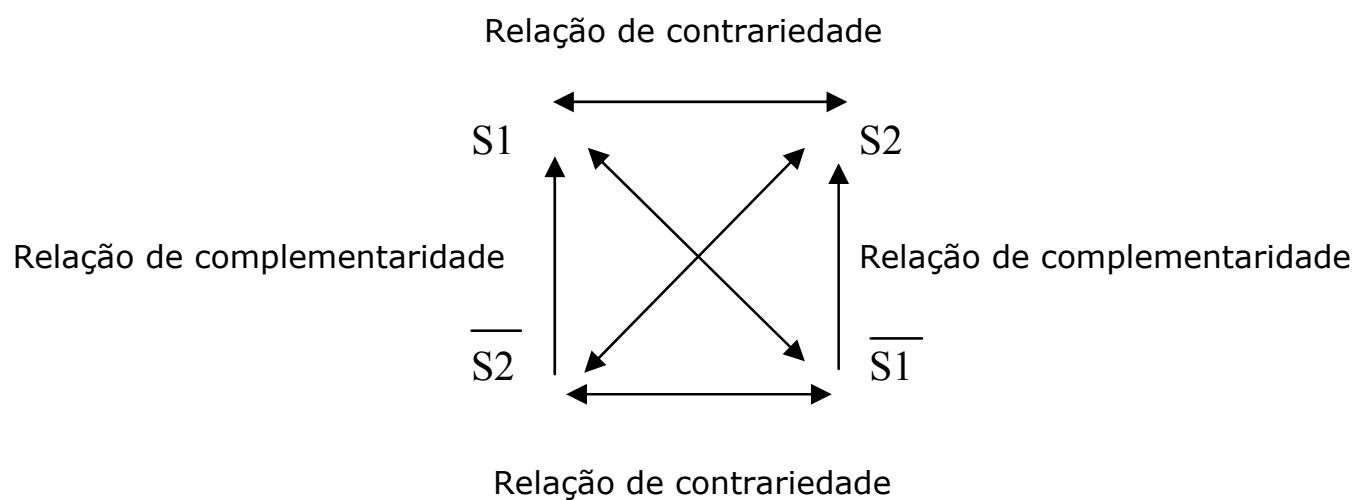

Figura 2: Quadrado Semiótico 
Quanto ao contrato fiduciário ${ }^{3}$ estabelecido entre destinador e destinatário no início de um percurso, poderemos ter um contrato que se estabeleça via manipulação ${ }^{4}$ por tentação ou intimidação (o manipulador mostra poder) ou por provocação ou sedução (manipulador mostra saber), tendo em mente que é o destinador-manipulador que faz o sujeito fazer. 0 destinador pode ser figurativizado por três atores no nível discursivo, numa situação que exige um percurso tematizado pela busca de um saber lingüístico, assim teremos o destinador-educador, quando falamos em ensino-aprendizagem e um destinador-mercado de trabalho ou chefe de departamento, quando num ambiente de trabalho, cada qual aparecendo em situações distintas da vida do sujeito destinatário, que também é figurativizado por dois atores, ora educando ora funcionário, dependendo da situação que ele estiver vivenciando.

Quando identificamos as estruturas gramaticais da semiótica conjuntamente com seus componentes sintáticos ou semânticos num "texto", poderemos enfocar na maneira pela qual esse texto constrói o que ele diz e, dessa forma, isentamo-nos de nossas opiniões ou ideologias, pois temos um instrumental metodológico que permite olharmos para o "texto" sem distorções ou preconceitos. Logo, a leitura semiótica procura mostrar o como se dá a construção do sentido ao olharmos o mundo, ou seja, uma imagem, uma situação, pessoas ou lugar, observando o mundo como um texto. O educador poderá partir desses conceitos teóricos de

3

Contrato fiduciário: as relações que se estabelecem entre os sujeitos (enunciador e enunciatário) estabelecem contratos no nível discursivo que podem ou não adquirir um caráter veridictório se houver coerência e consistência na maneira pela qual o discurso vai sendo construído. Esse contrato pode ser considerado falso, mentiroso, verdadeiro ou secreto. A interpretação desse contrato veridictório dependerá da interpretação do enunciatário que poderá ou não aceitar a manipulação feita pelo enunciador num discurso.

4

Manipulação: para a semiótica a manipulação não deve ser entendida negativamente como o senso comum compreende, o destinador propõe uma ação e essa poderá vir em forma de tentação, provocação, sedução ou intimidação e poderão ser aceitas ou não pelo sujeito destinatário dessa manipulação. 
uma análise semiótica para analisar seu educando e sua própria aula, construindo ou reconstruindo estratégias para a construção de sentido de uma língua estrangeira. Assim, o educador poderá fazer uma leitura do processo de ensino-aprendizagem, analisando e compreendendo a construção do sentido desse mesmo processo.

Essas estruturas gramaticais da semiótica greimasiana aplicadas a um processo de ensino-aprendizagem são representados pelas figuras do discente, mercado de trabalho e do docente. Todos os atores envolvidos nesse processo assumem diferentes papéis actanciais durante o percurso. O ator-educador poderá assumir papéis actanciais distintos em um percurso de ensino-aprendizagem como, por exemplo, o de destinador ou anti-sujeito, o de adjuvante ou antiadjuvante, pois dependerá da relação que o docente estabelecer durante esse processo. $O$ ideal, nessa situação, seria um ator-educador que fosse um sujeito-destinador e adjuvante de um saber lingüístico e, assim, pudesse orientar o sujeito-aluno na aquisição da L2, levando-o a entrar em conjunção com o seu objeto de valor, ou seja, a língua inglesa.

Podemos notar que durante esse processo é comum que o sujeitodestinatário, discente ou funcionário, construa simulacros ${ }^{5}$ sobre um sujeito-destinador, docente ou mercado de trabalho, e esses simulacros irão, em princípio, nortear a atitude do sujeito-destinatário com relação à L2. O destinador-mercado de trabalho impõe ao seu funcionário, sujeitodestinatário, um agir, isto é, procurar uma instituição de ensino ou professor particular para aprender a língua inglesa. Analogamente, o destinador-educador transmite e gera em seu destinatário-educando um outro agir que é da ordem de um /saber-fazerl. Todavia, esse mesmo sujeito-destinador de um saber poderá gerar uma situação de insatisfação

5 Simulacros: são imagens que o sujeito constrói a respeito de algo ou de alguém partindo de suas crenças e saberes e, acabam por orientar sua visão de mundo e suas relações com outros sujeitos ou objetos. 
e, dessa forma, um mal-estar em seu destinatário e, por isso, afastará esse sujeito-destinatário de seu objeto de valor, desmotivando-o ou, até mesmo, poderá perder sua confiança, levando-o a desistir de aprender a L2.

Diante dessas situações, o destinador-educador poderá assumir dois papéis actanciais, ou seja, ou ele será coadjuvante do sujeito-destinatário (educando) ou ele será anti-coadjuvante nesse processo de ensinoaprendizagem. Esses destinadores fazem o sujeito fazer por meio das classes de manipulação (tentação, provocação, intimidação ou sedução). No caso de um destinador-mercado de trabalho teríamos uma manipulação por meio da intimidação e, algumas vezes, por tentação, ou seja, um discurso de persuasão via poder ou saber. $\mathrm{O}$ destinador-educador procura manipular seu destinatário ora por meio de uma sedução ora por meio de uma tentação. Voltaremos a essas questões de manipulação mais detalhadamente no Capítulo $\vee$ deste trabalho.

Esse processo ocorre da seguinte maneira: o destinador (educador) manipula o destinatário (educando) a um fazer, persuadindo-o a amplificar o seu saber lingüístico, por exemplo, ler, estudar, fazer as tarefas, dentre outras atividades. Essa manipulação é dada de formas diferentes, pois dependem das crenças e valores do docente. A performance do educando será proporcional à abordagem de seu educador tanto no modo como ele se relaciona com o educando, como no modo de transmitir o saber, que são dois aspectos da educação completamente diferentes. Entretanto, eles precisariam complementar-se para surtir um efeito positivo no educando, levando-o a agir positivamente em relação ao seu Ov.

Em contrapartida, o educando deverá envolver-se em seu processo de ensino tanto quanto possível para que obtenha um discernimento maior da língua e, para que isso ocorra, ele precisará ter em mente o motivo pelo qual quer aprender aquela língua. Assim, esse educando não poderá perder de foco seu objetivo durante seu processo de aprendizagem, pois 
será esse objetivo que o motivará para continuar estudando e empenhando-se cada vez mais.

Os traços perceptivos de uma cultura, comparados com uma outra, são distintos entre si e, assim, são os indivíduos também, pois possuem percepções e experiências diferentes, que uma vez selecionadas, são acionadas pelo educando para identificar e serem reconhecidas ou não. A interpretação dessas percepções e experiências dependerá da forma como o sujeito-aluno percebe e, nesse caso, é o educador quem facilitará essas experiências para que ele - educando - possa identificar a idéia/conceito, ou melhor, o sentido dos signos lingüísticos da L2. Nesse sentido, identificamos apenas o que reconhecemos, portanto pressupõe-se uma representação anterior daquilo que foi experienciado ou vivido. O educando precisará representar ou simbolizar o que lhe é falado em uma outra língua, distinta da sua e para isso o educador precisará ter uma boa estratégia e aparatos metodológicos coerentes e consistentes para tornar a L2 passível de reconhecimento tanto para o significante oral/auditivo quanto para o significante escrito.

Por conseguinte, precisará utilizar de outras linguagens que possam representar ao educando algo do mundo natural, colocando-as em situações pragmáticas e, por sua vez, ele poderá atualizar esse novo código não só na memória de curto prazo, mas também na de longo prazo que será importante para que se estabeleça qualquer forma de expressão em outra língua e, assim, o educando poderá identificar, reconhecer, interpretar e, conseqüentemente, semiotizar a $L 2$, tornado-a um mundo semioticamente possível.

A análise semiótica Greimasiana permite-nos ter uma visão mais profunda e acurada das relações entre o enunciador-destinador e do enunciatário-destinatário, pois o sentido é construído a partir do discurso do educador que pode ser uma manipulação por meio da sedução/tentação 
(querer) ou pela ameaça/provocação (poder), partindo disso, o educando constrói o seu saber mas, em contrapartida, o sujeito-aluno precisará ir ao encontro de seu Ov, para construir um sentido, também.

O docente trabalha o /fazer-crer/ no educando, mas precisa de um Isaber-fazerl que leve o educando a um /querer-fazer/ e /crerl na possibilidade de aprender algo que considera difícil ou acredita ser incapaz de aprender. $O$ educador construirá um discurso que faça o educando /fazer-crerl e /fazer-fazerl desde que tenha competência, ou melhor, um /poder-saber-fazer/ o outro construir um novo saber lingüístico, dotando-o de um /saber-fazerl e /poder-fazer/.

O sujeito-aluno foi, de alguma forma, manipulado pela sociedade que $\mathrm{o}$ fez lquererl entrar em conjunção com seu Ov - a língua inglesa - para que ele tenha acesso a esse saber lingüístico e possa, dessa forma, fazer parte de um mercado de trabalho.

O papel do educador, nesse processo de ensino-aprendizagem, é o de destinador desse saber por meio de seu conhecimento, fazendo o educando ter um outro saber acerca do mundo; o educador desencadeia o agir do sujeito-aluno, destinatário desse conhecimento. Ambos os sujeitos são modalizados por um querer, o discente querendo um saber e o docente querendo transmitir esse saber. Em princípio, essa seria uma situação "ideal" ou desejada, é o que esperamos de uma relação de ensino-aprendizagem, mas nem sempre é o que ocorre mediante a realidade em que o sujeito-aluno está inserido.

Além disso, não basta o conhecimento do educador (competência), seu desempenho em fazer o outro entender é tão importante quanto o processo em si de ensino-aprendizagem. A performance (desempenho) pressupõe uma competência, mas o inverso não é verdadeiro. Enquanto para o educando a sua competência será sancionada positivamente se 
houver um comprometimento do educador e do próprio educando nesse processo. Por outro lado, poderá ser sancionada negativamente se houver um ensino falho ou um não envolvimento com o processo de aprendizagem por parte do educando, isto é, um desempenho não satisfatório durante o seu processo, podendo também ocorrer em ambos os casos (ensino falho + não participação do educando).

Assim visto, a semiótica coloca-se a serviço de outras ciências como as sociais e humanas, procurando entender a construção do sentido em qualquer "texto", já que ele possui uma estrutura subjacente que nos diz algo ou remete a alguma coisa, ou seja, relaciona a expressão e conteúdo de uma determinada linguagem dentro de um contexto. Essa teoria constrói uma relação não só entre sujeitos, mas entre seus objetos, também. Tanto o sujeito como o objeto estão em relação, pois estar em uma aula de idiomas é construir uma relação entre sujeito-aluno e sujeitoeducador e construir também uma relação entre sujeito-aluno e seu objeto de valor e sujeito-educador e seu objeto de valor. Tanto o sujeito quanto o objeto não estão separados nessa teoria, o sujeito aproxima-se de seu Ov. Apesar de estarem numa relação de contrariedade, também teremos uma relação de complementaridade para que ocorra uma transformação dos sujeitos envolvidos nessa relação de ensino-aprendizagem.

Ao educador cabe a tarefa de observar a lógica de significação daquele sujeito, a quem a semiótica discursiva passará a auxiliar em sua trajetória, na busca de um /saber-fazerl e produzir no indivíduo, mesmo que o sentido geral da maneira pela qual o sujeito recorta o mundo e o reestrutura escape de nossa compreensão, pois existe uma impossibilidade de captar o todo, mas as estruturas narrativas e modais que sustentam aquela lógica de cognição estão sempre presentes nos mecanismos de comunicação dos seres humanos, auto-regulando-se e auto-alimentando-se, nas relações com o mundo que cerca o sujeito, 
produzindo sentidos, significações sobre seus valores e visão epistêmica desse mundo. Esse destinador-educador doa uma competência ao sujeitoaluno e zela para que a performance desse sujeito-destinatário de um saber seja otimizada.

O discurso do educador, sobre o objetivo da aprendizagem de uma língua, deve também ser muito claro para que ele sempre possa mostrar ao sujeito-aluno o motivo pelo qual o educando está fazendo o curso, relembrando o contrato firmado no início do curso. A manipulação do educador leva o sujeito-aluno a /fazer-fazer/ e com o tempo ele passará a lquerer-fazerl e /saber/ por si mesmo, sobretudo quando tiver de cumprir algumas tarefas que envolvam a língua inglesa em seu trabalho ou em suas viagens, até mesmo em momentos de lazer como assistir a um filme ou escutar uma música. Todavia, para realizar seu desejo e ir ao encontro de seu Ov, o educando precisará realizar um percurso que não será fácil, pois para que esse percurso transcorra de forma eficaz, é necessário um grande esforço de sua parte e tempo de dedicação.

Assim sendo, o saber será análogo ao tempo estudado, otimizado e amplificado, dependendo da ação investida no Ov. Ao final do percurso, a sanção será positiva ou negativa, dependendo da forma como foi trabalhada a relação do sujeito com seu objeto. Para que a ação desse sujeito sobre seu Ov seja sancionada positivamente é desejável que o educando saiba como utilizar o seu tempo de forma produtiva, o que significa deixar de fazer o que ele realmente gosta de fazer ou prefere fazer em seus horários livres, gerenciando assim, o tempo disponível, apesar das dificuldades que cada indivíduo adulto possa encontrar nesse percurso. Fazer o educando entender esse processo é uma condição para um entrosamento melhor e maior com a língua inglesa, e muitos deles acabam tomando gosto pelo idioma, algo que em princípio era /dever/, transforma-se em /querer-saber/ mais, pois é seduzido pelo saber. 
Procuramos sempre incitar no educando um olhar mais atento em vez de simplesmente "ver um saber lingüístico". A idéia é fazer com que o sujeito-aluno desperte para um 'olhar sensível' e reflita sobre a língua inglesa, observando a maneira pela qual ela é construída. Não basta o docente transmitir uma série de informações acerca dessa língua, uma vez que ele precisa da mediação para representá-la, ou seja, simbolizar o que está sendo ensinado ao educando, e este possa relacionar essas novas informações com o que elas representam no mundo e, assim, acabe por construir um sentido para tais informações. O educador parte de um significante (ou representamen) no mundo exterior para mediar a L2 e levar o sujeito-aluno a construir suas imagens mentais que são organizadas pelas percepções sensoriais. Como diria Landowski (2001):

\begin{abstract}
O universo inteiro é uma espécie de texto que lemos continuamente, não só com os olhos, mas com os cinco sentidos. O problema é então conceber as categorias suficientemente gerais que nos permitam reconstruir, em toda a sua variedade e riqueza, a maneira pela qual $o$ mundo se apresenta a nós - e pela qual ele significa para nós - ao mesmo tempo como mundo inteligível e como mundo sensível. (doc. eletrônico, 28 de fev. 2003)
\end{abstract}

Nesse contexto, a semiótica é um instrumento que permitirá uma leitura mais objetiva, fornecendo meios para analisar o que é dito, por meio de um modelo de previsibilidade. É possível, então, depreender os efeitos de sentido em qualquer texto e de forma mais rápida por meio da imanência. Sendo assim, a semiótica irá empenhar-se em descrever a maneira de as coisas significarem no mundo, ou seja, seu objetivo é procurar descrever e explicar o que um "texto" diz e como ele fará para dizê-lo. 


\subsection{Aspectos da psicanálise Lacaniana aplicadas ao ensino de}

\section{língua inglesa}

Jacques-Marie Émile Lacan (1901-1981) foi um psicanalista polêmico que fez uma releitura das idéias de Freud, repensando-as à luz da lingüística estrutural. Dessa forma, inspira-se nos trabalhos de Saussure (1969), Jakobson (1969) e Lévi-Strauss (1955), criando o aforismo que o inconsciente está estruturado como uma linguagem (1966), dentre outros.

Todavia, além do conhecimento da lingüística, Lacan também utiliza do conhecimento da matemática, da lógica e da topologia em seus estudos da psicanálise. Esse autor insere a psicanálise no campo da linguagem e a enfoca na função da "fala". Com relação à lingüística estruturalista, Lacan ancora-se na idéia das relações entre os elementos. Quando falamos em um inconsciente estruturado como uma linguagem, Lacan quer dizer que esse inconsciente irá se organizar da mesma maneira que uma linguagem se estabelece, ou seja, pelas constantes articulações combinatórias de seus elementos significantes que ocorrem de maneira sincrônica, contingente e casual.

Em vista disso, acreditamos ser importante trabalhar com a questão do inconsciente, já que lidamos com o outro ou o pequeno outro (do francês autre). Esse outro, segundo o ponto de vista Lacaniano, é aquele indivíduo que se encontra em uma posição de inferioridade ou de menos saber ou menos poder, que está contrário à figura do Grande Outro ou Outro (Autre) que por sua vez detém um saber, conseqüentemente, um poder.

O educando olha para o Grande Outro (educador, chefe ou mercado de trabalho) esperando aprovação, um olhar que o autorize a fazer o melhor possível. O olhar do Outro nos devolve a imagem de quem somos. Dependendo de como o pequeno outro constrói essa imagem, ele terá uma 
identificação maior ou menor com o objeto de estudo. Esse pequeno outro (educando/funcionário) procura identificar-se com o Grande Outro para suprir suas faltas, suas carências e quando não as encontra, um conflito será instaurado, causando um sintoma.

Tal sintoma, sob o ponto de vista Lacaniano (1953, Seminário I), é algo que mascara o desejo, sutura um problema inconsciente, e o indivíduo não consegue relacionar sua angústia ou sofrimento com sua fantasia, ou seja, algo que não é da ordem do real. $\mathrm{O}$ sintoma só será desatado quando o próprio indivíduo perceber a sua falta e o que the incomoda a esse respeito. Geralmente, o sintoma ocorre quando o sujeito se encontra em uma situação que advém do desejo do Grande Outro e não necessariamente de seu próprio desejo; por isso sujeita-se ao discurso do Outro para poder ser inserido e aceito em um contexto específico.

Diante desse quadro, temos uma sociedade que compele um indivíduo ao seu desejo e o manipula, por meio de uma coação ou tentação a ir ao encontro das necessidades específicas de um mercado de trabalho extremamente competitivo. Logo, o sujeito encontra-se obrigado a saber a língua inglesa, levando-o a procurar uma instituição de ensino ou um professor com trabalho individualizado e/ou em grupo.

Quando esse sujeito do desejo do Outro iniciar suas aulas, dando, assim, o primeiro passo, o papel do educador, nesse momento, é procurar fazer com que o sujeito-aluno entre em conjunção com seu Ov, levando-o não só a entender uma outra língua, mas também a transformar esse estado inicial do /não-desejar/ ou Inão-querer/ aprender uma língua, em um lquererl verdadeiro, que tenha partido de sua própria vontade, pois essa atitude poderá melhorar e ampliar seu conhecimento mais rapidamente. No entanto, algumas vezes, esse Inão-desejar/ ou Inãoquererl aprender uma língua, encontra-se velado, por receio de ser mal- 
interpretado por outras pessoas ou devido àquelas tentativas frustradas do seu passado para aprender a L2.

Caberá ao educador propor um outro ponto de vista acerca da língua, distinta do que foi vivenciado no passado e ao mesmo tempo prazeroso, pois vai ao encontro de assuntos que interessam ao educando e, dessa forma, o desejo do Outro é transformado em seu desejo, pois passará a fazer sentido o aprendizado de uma nova língua. Contudo, devemos partir da demanda do outro, considerando que esse outro precisará assumir uma ação e envolver-se em seu próprio processo, uma vez que o educando precisa perceber a necessidade de aprender cada vez mais a respeito da L2, tendo o educador como um facilitador nesse processo de ensinoaprendizagem.

Além disso, Lacan (1993 apud Hassan, p.99) ${ }^{6}$ afirma que 0 inconsciente é o discurso do Outro, quando se refere ao registro de relação do sujeito com o Outro, uma vez que temos um sujeito que se regula pelo desejo do Outro e as relações entre os indivíduos acabam sendo reguladas por desejos. O desejo pressupõe a falta de algo, assim sendo, no ponto de vista de Lacan (informação verbal) ${ }^{7}$, o desejo é a necessária relação do ser com a falta. Dessa maneira, esse Outro toma um lugar simbólico que será uma referência para o pequeno outro, como se fosse uma Lei ou castração a que o sujeito está submetido.

O inconsciente é algo que não podemos ver, mas produz efeitos visíveis na forma de sintomas, dentre outras ocorrências. O sujeito se entrelaça em seu sintoma, pois acredita nele. Para Lacan, o sintoma é uma mensagem cifrada em significantes, cujo significado reprimido está à espera de ser esclarecido ou decifrado pelo outro. No Seminário I (1983,

6 RAPPORT, C.R. , HASSAN, S.E. e MOLLOY, C.S. Psicanálise - Introdução à práxis Freud e Lacan,1992.

Anotação das aulas de Psicanálise e Educação Inclusiva, ministradas pela Profa. Dra. Leny M. Mrech na Faculdade de Educação da Universidade de São Paulo, em 2003. 
p.85), Lacan assegura que o sintoma é um indício da história do sujeito. $O$ Sintoma é a defesa contra o real, um modo de lidar com a falta e ocorre quando um indivíduo não consegue gerenciar ou lidar com uma situação.

O conhecimento de um saber é transmitido por esse Outro com quem o educando começa a identificar-se e, assim, o objeto de estudo que antes poderia ser de pouco interesse passa a ser de seu interesse devido à relação que se estabelece entre educador e educando. É dado ao educador o lugar de sujeito suposto saber que é atribuído a alguém que tenha um saber suposto, ou seja, o pequeno outro (educando) atribui ao Outro (educador) esse saber suposto. O discurso pedagógico estabelecerá um vínculo com seu educando, instaurando um percurso possível para a interlocução entre a língua e educando através do Outro, possibilitando, assim, fazer com que o sujeito-aluno desate os nós que foram atados anteriormente em uma situação de ensino-aprendizagem, pois o que é manifestado pelo educando - com relação à língua ou pela maneira que ele percebe o papel do educador nesse percurso - é uma defesa em forma de recusa e descontentamento de tentar aprender ou envolver-se mais em seu próprio processo.

Sendo assim, teremos uma tensão dialética entre consciente vs inconsciente, saber vs não saber, ou melhor, um dever-saber vs querersaber e, muitas vezes, o /dever-saber/ acaba levando ao /querer-saber/, dependendo do percurso metodológico que o educador escolher para transmitir esse saber. $O$ que antes era uma obrigação poderá vir a ser um prazer. A passagem do /dever-saberl ao lquerer-saberl ocorre gradualmente e torna-se mais eficaz quando o saber lingüístico é construído de forma a levar o educando a lquerer-saber/ mais sobre a L2. O educando é levado a conhecer um outro mundo e é inserido nele de maneira "sedutora". O discurso do educador promove nesse discente um 
movimento, uma ação que será realizada pelos esforços do educando por meio da expressão oral e escrita da língua-objeto.

O investimento desse saber será visto pelo Outro, nesse caso o mercado de trabalho ou o chefe de departamento, como algo positivo para a empresa e pelo próprio educando como um elemento motivador e, assim, poderá expressar-se em uma outra língua, sobretudo, preencher os requisitos de um mercado competitivo. O que antes parecia ser impossível passará a ser possível e prazeroso, incentivando-o a continuar em seus estudos. O educando passará a ter uma imagem mais confiante de si próprio e acabará organizando-se melhor nos estudos, enfocando mais em seu objeto, conseqüentemente, na recompensa que virá com o novo saber. O olhar do Outro, que antes era da não aceitação, da não possibilidade e do não poder, passa a ser de aceitação e inserção no mercado de trabalho.

Uma falta que o sujeito percebeu ter, pois foi levado a crer que sem aquele saber ele não seria parte de um mercado de trabalho, já que não poderia comunicar-se com outros em suas viagens internacionais de negócios ou, até mesmo, pelo simples fato de querer compreender uma música, fez esse sujeito ressentir-se dessa situação de falta e que só poderia ser preenchida se ele fosse em busca de um saber lingüístico. $O$ discurso do Grande Outro fez com que ele buscasse o que fosse necessário para ser inserido, mesmo que, inicialmente, ele ainda não pudesse perceber a aprendizagem de uma nova língua como um fator positivo. É nesse instante que o sujeito-aluno é caracterizado pela falta; um "sujeito em falta" que busca um saber, entretanto, não partiu de sua vontade, veio pré-determinado por um /dever-fazerl do Outro (mercado de trabalho ou o chefe de departamento da companhia).

Provavelmente, essa necessidade do mercado de trabalho (saber a L2), diante de uma era globalizada, configura-se em um empecilho na carreira profissional do indivíduo. Para que esse indivíduo seja inserido no 
mercado, será preciso que ele busque uma maneira de ir ao encontro de seu Ov, para conseguir seu objetivo, mesmo que precise negar suas próprias vontades. O desejo de um Sujeito do inconsciente é distinto do sujeito psicológico (1992 apud MOLLOY, p.139) ${ }^{8}$ e quando esse inconsciente se abre ou se mostra virá sob a forma de sintomas, sonhos ou lapsos, pois o verdadeiro desejo está disfarçado nesses sintomas, como por exemplo uma resistência em /não-querer/ ou /não-desejar/ fazer algo (natureza vs cultura); todavia, os fatores externos compelem o indivíduo a agir e, portanto, existir nessa sociedade, fazendo, assim, parte dessa globalização que possui uma língua hegemônica dominante no mercado internacional.

Segundo levantamento das entrevistas realizadas com os discentes, a resistência do educando ao saber lingüístico está associada, na maioria dos casos, aos problemas provenientes do passado, seja com idioma ou com a postura do docente, quanto à transmissão da L2 e na maneira pela qual ele lida com seu educando, não desconsiderando a possibilidade do domínio das pulsões, já que alguns educandos não gostam ou não querem aprender a língua inglesa, mas o fazem por obrigação, ou seja, para o cumprimento de uma ordem ou necessidade exigida no mercado de trabalho e, conseqüentemente, uma inserção nesse mesmo mercado.

A sociedade exige uma sujeição do indivíduo pela demanda do mercado de trabalho; por essa razão instaura-se o mal-estar com relação à língua estudada e, mediante esse sintoma, o professor-educador busca uma outra forma de lidar com o educando, levando-o a crer na possibilidade de aprendizagem, resgatando, assim, sua confiança que

$8 \quad$ Molloy diz que o Sujeito Psicológico é "a pessoa, sede de afetos, vivências e sentimentos, aquele que sabe a respeito de si, é causador de sentidos e significações. $O$ Sujeito do Inconsciente, pelo contrário, é efeito da relação entre significantes e se expressa na descontinuidade, aparece na consciência como um desconhecimento". 
havia sido minada e agora será retomada por um educador mais consciente desse mal-estar.

No entanto, comunicar-se é importante nesta sociedade globalizada, cujas notícias e negociações exigem a mediação de uma língua comum para atender as necessidades do mundo atual, bem como nos comunicarmos com outras culturas on line, propiciando também, a participação em eventos internacionais, cursos no exterior ou a leitura de artigos científicos nos diversos campos da ciência, além de ajudar na comunicação numa viagem a lazer. Dessa forma, o indivíduo não tem outra opção senão aceitar o que o mercado lhe impõe como condição de inserção, não só de mercado, mas também para outros papéis sociais que ele queira ocupar nessa sociedade.

O sujeito-aluno, por vezes resistente e ressabiado, é o produto dos discursos dominantes em nossa sociedade, ou seja, da voz que critica ou que manifesta por meio do olhar e das reações corporais um distanciamento ou, até mesmo, um desdém na maneira de ensinar ou de lidar com o outro, os quais não passam despercebidos pelo discente. Nesse caso, tratamos de um discurso sem palavras e mesmo que não digamos nada no momento de uma relação de aprendizagem, o educando pode inferir algo, já que está inserido numa relação, em que os atos importam tanto quanto ou mais que palavras. Lacan retoma a idéia de Freud (informação verbal) ${ }^{9}$, ao dizer que a maior fonte de sofrimento é a relação entre pessoas, por isso Lacan fala do mal-estar como um sintoma que é observado no educando e, até mesmo no educador, este com relação à profissão e aquele com relação à língua.

\footnotetext{
$9 \quad$ Palestra de Benilton Bezerra da Silva sobre o tema Corpo, Mente e Mundo: Psicanálise e Budismo. A construção da identidade no mundo atual, apresentado na TV Cultura no programa Café Filosófico no dia 25/05/2006
} 
O fato de alguns indivíduos terem verdadeira aversão ou, até mesmo, receio de aprender um idioma, leva-nos a pensar numa espécie de recalque, do qual o sujeito não tem consciência do real motivo de não gostar da língua inglesa. O recalcamento é um processo, segundo Freud, exercido pelo Eu e que afastará da consciência a representação de algo que tenha sido ruim ou penoso para o sujeito. Assim sendo, esse sujeito mantém distância daquilo que lhe causa um desafeto ou um desprazer relativo a algo ou alguém. $O$ sujeito-aluno verá em seu Ov ou no docente a representação desse desafeto, do qual ele quer manter-se distante, apesar de precisar entrar em conjunção com esse objeto de valor, o que significaria termos de modalizar esse /não-quererl, que, em alguns casos, encontra-se velado em um /quererl.

No caso daqueles que aceitam o fato de não gostarem da L2, mas terem de aprender por razões das quais eles têm consciência, o trabalho do educador será diferente, pois podemos levá-los a pensar e a lidar de outra forma com seu Ov. Contudo, se o docente colocar a aprendizagem da L2 como norma obrigatória, ou seja, como um discurso impositivo no qual o discente não tem direito a uma escolha na maneira de trabalhar em seu próprio processo ou não existe um diálogo entre educador e educando a despeito da forma de tornar a aprendizagem mais "aceitável", provavelmente, o docente estará sujeito a perder a confiança do seu educando e, por conseqüência, o afastará mais ainda, colaborando para o agravamento do sintoma.

O educador não "bate de frente" com o desafeto mostrado por seu educando. Ele escuta e trabalha de uma outra forma esse mal-estar, contornando-o e levando, aos poucos, seu educando a perceber que aprender a língua inglesa não é tão difícil ou desagradável como poderia parecer e que ela the trará outras compensações. Para Lacan, esse recalque ou a representação de um mal-estar estaria relacionado ao que 
ele designou por significante, ou seja, "... [o significante] é fruto de um movimento de censura e de recalque, pelo qual uma representação fica para sempre excluída do sistema consciente" (1992, Molloy, p. 129) ${ }^{10}$.

O valor da escuta é primordial para o educador quando analisa a fala de seu educando, não só por meio de sua produção oral na L2, mas também sobre o que ele pensa da língua inglesa, seus temores e suas dificuldades e, em particular, a maneira que ele estuda essa língua. Essa escuta é um meio de o educador avaliar seu sujeito-aluno, num primeiro momento, e ajudá-lo a construir um liame com o novo saber, levando-o a (re)pensar numa maneira de lidar com seu Ov.

Nesse sentido, o educador busca outras possibilidades para fazer o seu educando aprender uma outra língua e ir ao encontro de suas necessidades e gostos. Essas outras possibilidades são situações reais de interesse do sujeito-aluno, como por exemplo, falar sobre vinhos, plantação de café, esportes, ou seja, assuntos que estejam relacionados à vivência do educando, pois ele traz consigo um conhecimento ou um interesse sobre algo e, então, buscamos na L2 um assunto que trabalhe com o mesmo tema que interessa a esse discente.

Por conseguinte, a aula passará a ser mais atraente para o educando, além de ser mais fácil a compreensão por ter um conhecimento prévio de um assunto que ele domina ou gosta. Dessa forma, são utilizados outros saberes que possam dialogar com a língua que se está aprendendo ou poderemos utilizar outras linguagens como a música, o vídeo ou a internet, dentre outros, para exercitar a leitura, o léxico, praticar exercícios ou, simplesmente, exercitar uma conversação, fazendo o educando chegar ao seu objetivo, isto é, à aprendizagem de uma língua estrangeira.

10 RAPPORT, C.R. , HASSAN, S.E. e MOLLOY, C.S. Psicanálise - Introdução à práxis Freud e Lacan,1992. 
As situações reais ou até mesmo simuladas (representação de uma situação ou role play) auxiliarão na ativação e atualização do sistema e darão um suporte lingüístico maior ao educando, além de fortalecerem sua auto-estima, provendo-o de contextos outros da língua inglesa, motivandoo também a procurar por si mesmo outros assuntos e tornando-o, assim, mais seguro acerca da língua. Com o tempo, aquele mal-estar vai se apagando e um outro simulacro será formado pelo sujeito-aluno.

Freud (informação verbal) ${ }^{11}$ diria que o "eu" (= identidade) só surge conjuntamente com o outro, ou seja, sua alteridade e essa mesma idéia foi retomada por Lacan. Comungamos com a alteridade do ambiente ou do outro, pois estamos inseridos em um mundo. A interação leva a uma ação sobre o mundo, dessa forma produzimos. Sabemos que existe um diálogo incessante entre indivíduo e sociedade, ou seja, uma tensão dialética entre o pequeno outro e o Grande Outro (figura de poder), que em princípio estão em conflito. $O$ desejo de aprender vem primeiro da demanda de mercado de trabalho e, talvez depois, venha da vontade do educando de aprender uma outra língua para poder se comunicar e entender um outro universo lingüístico e discursivo. Diante disso, o discurso desse Grande Outro é um discurso do poder, em que predomina apenas uma voz e a do pequeno outro é apagada, pois não lhe é permitido falar.

Em princípio, a relação do sujeito-aluno com seu Ov é pautada na exigência de um mercado para conseguir um cargo melhor em sua companhia ou uma colocação no mercado, ou até mesmo para assegurar seu emprego, pois há uma pressão do mercado e de um chefe que assegurará a posição desse sujeito na empresa se o funcionário souber se expressar na L2. Esses fatores, sobretudo o último, podem atrasar o desenvolvimento do educando, além daqueles fatores que remetem ao

\footnotetext{
11 Palestra de Benilton Bezerra da Silva sobre o tema Corpo, Mente e Mundo: Psicanálise e Budismo. A construção da identidade no mundo atual, apresentado na TV Cultura no programa Café Filosófico no dia 25/05/2006.
} 
passado desse sujeito-aluno e que já foram comentados nos limites desse trabalho, levando-o também a um bloqueio cognitivo.

O discurso de um docente que não vincule a construção de um saber ou que subestime o papel do estudante, dentro de uma relação de ensinoaprendizagem, gera uma sensação de mal-estar, dificultando a ligação do sujeito ao saber lingüístico. Com o passar do tempo, há uma perda do desejo de continuar estudando, e o educando acaba por desfocar-se de seu Ov, o que poderia ser uma das razões que o leva à falta de motivação, o que acarretaria em um não desenvolvimento lingüístico e provável afastamento das aulas.

Notamos uma insatisfação em alguns casos e, em outros, um pouco de revolta por parte dos discentes, que já passaram por inúmeras tentativas de aprendizagem da língua inglesa. O sujeito desprovido de uma saber lingüístico passa a hostilizar a língua. Um sentimento de decepção faz-se presente e instaura-se na cognição, bloqueando seu entendimento, sua proximidade com a língua e, até mesmo, com o educador, pois já possui um pouco ou muito receio da figura do Grande Outro representada aqui pelo papel do educador.

Diante dessa situação, o educando hostiliza a língua, resistindo à aprendizagem da mesma e mantém-se na "defensiva" com seu educador. Essas atitudes são perfeitamente normais, pois temos um sujeito cindido que se encontra total ou parcialmente insatisfeito, manifestando, como defesa, uma recusa em /querer-aprender/ devido às experiências anteriores de ensino. Com o passar do tempo, se tais experiências permanecerem, o mal-estar será reafirmado, uma vez que ninguém conseguira desfazê-lo, por conseqüência, haverá um processo transferencial com o próximo educador, pois esse Outro assumirá o lugar do anterior, ou seja, ele deverá substituir a figura representativa de seu passado. 
Geralmente, o quadro apresentado pelo educando é de um indivíduo que se culpa por não conseguir aprender a língua, desarticulando, assim, sua confiança e, na maior parte dos casos, carrega consigo aqueles sintomas do seu passado, transferindo ao próximo docente esse mal-estar que, certamente, provocará um distanciamento do novo educador e um desafeto pela L2.

Infelizmente, uma falta que não foi sanada no passado, tornou-se um fardo a ser cumprido no presente devido às exigências do mercado de trabalho. Resta a nós, educadores, poder transformar esse sentimento de falta em algo possível de ser aprendido e substituir o sentimento de desconfiança por confiança nessa relação de ensino-aprendizagem, acreditando na capacidade do sujeito-aluno de /poder-aprenderl o que antes parecia ser impossível e na competência do Grande Outro em tentar ajudá-lo a percorrer um caminho de maneira mais proveitosa, coerente e consistente.

A resistência mostra-se muito clara nas atitudes e comportamentos do educando em um primeiro momento, diante disso o educador precisará resgatar e reconquistar a confiança dele, restaurando-a a cada aula. $\mathrm{O}$ sujeito-aluno busca um reconhecimento que é obtido por meio do olhar mais atento de seu educador; assim, os sintomas são amenizados e aumentamos a auto-estima e motivação do educando que agora se sente mais confiante e confortável em sua aprendizagem. Vencer a resistência implica mudança de estado do educando e esforço do educador em promover essa mudança, pelo fato de reconhecer os problemas que esse sujeito experienciou no passado com a aprendizagem da L2. Portanto, teremos um educando que acabará por se envolver mais em seu próprio processo, tornando-se mais participativo não só nas aulas, mas em outras circunstâncias de aprendizagem da língua inglesa. 
Apesar de termos um indivíduo que deseje ou queira aulas de inglês, o educador deve ter em mente que o desejo ou a demanda partiu do Outro, são raros os casos de sujeitos que procuram aulas de inglês pelo fato de gostarem da língua e quererem estudá-la. Esse Outro é representado pela figura do chefe ou de um mercado de trabalho globalizado, que incita o indivíduo a procurar um meio de desenvolver habilidades lingüísticas na L2. De alguma forma, esse sujeito foi persuadido ou pela sedução ou manipulação ou coação para instar um enunciatário-destinatário a agir. Segundo Molloy (1992, p. 158) ${ }^{12}$ :

O ser humano somente se organiza num campo habitado pela linguagem. Dizemos que é falado antes de falar, e que este fato é determinante da sua objetividade. Não se alimentará se não existir, sustentado por um outro, o desejo de que coma. Não controlará os esfíncteres, até que a mãe solicite os excrementos, num lugar e tempo determinados. Não caminhará sozinho até que o desejo de um outro opere as ações necessárias para que isto venha a acontecer.

Isso posto, podemos esperar o mesmo tipo de ação de nosso educando quanto à aprendizagem de uma língua. Talvez o fato de o sujeito-aluno não incluir-se em seu próprio processo de aprendizagem, seja um dos motivos do não gostar e/ou ter dificuldades com a língua.

Por conseguinte, o educador precisa ter muito tato ao lidar com o outro, pois o filtro afetivo desse sujeito já vem com pré-conceitos, o que impede de o novo se estabelecer ou ser instaurado. Daí a necessidade de "gancharmos" o educando, fazendo-o olhar para a L2 por uma outra óptica, ajudando-o a sublimar as dificuldades durante sua aprendizagem. Como já foi dito, o destinador-educador é dotado de um /saber/ e ele destina ao seu educando esse /saber/ para que ele consiga ir ao encontro de seu Ov. Para

12 RAPPORT, C.R. , HASSAN, S.E. e MOLLOY, C.S. Psicanálise - Introdução à práxis Freud e Lacan,1992. 
isso, o sujeito-aluno é modalizado, sofrendo uma transformação que o fará entrar em conjunção com seu Ov.

Mesmo passando por alguns obstáculos, ou seja, anti-sujeitos (pressão do chefe, do mercado de trabalho e, até mesmo, uma não disponibilidade para estudar), ele deverá tentar ir ao encontro de seu objeto. Às vezes, o que é anti-sujeito acaba transformando-se em coadjuvante para a formação do indivíduo como, por exemplo, a pressão do chefe de departamento, que leva o sujeito-aluno a empenhar-se cada vez mais para conseguir a tão almejada promoção. O papel desse Grande Outro é o de promover em seu funcionário um movimento que, em princípio, não é aceito pelo pequeno outro, mas com o tempo aquele Outro fará o pequeno outro pensar em sua futura situação na empresa, levando-o a agir, provocando, assim, um movimento de busca.

Durante o percurso da aprendizagem, a figura do educador (ator) é tão importante quanto o percurso que o educando terá de fazer por si mesmo, se quiser agregar conhecimentos da L2. Numa reflexão anterior, comentamos que esse ator poderá ter papéis actanciais distintos na organização de uma narrativa discursiva sob o ponto de vista pedagógico (uma sucessão de estados e transformações desses estados, durante o percurso). O educador poderá ser um sujeito adjuvante se, de fato, cumprir seu papel social e participar ativamente da formação ou processo de seu educando, incentivando-o e mostrando-lhe meios para resolver problemas que possam ocorrer ao longo desse percurso, fazendo-o mudar sua atitude com relação à aprendizagem da L2. Ao contrário disso, poderá ser um antisujeito se passar a tratá-lo com indiferença, desrespeito, rudeza, preconceitos, até mesmo sendo intolerante com o 'tempo interno' de aprendizagem de seu sujeito-aluno. Por mais que um docente acredite que essas ações não sejam notadas pelo seu educando, este intui que algo não vai bem e passa a rechaçar a aprendizagem dessa língua estrangeira. 
Dos relatos levantados sobre a atitude do docente em aula, podemos compreender os danos tanto na auto-estima do discente quanto no modo de lidar com a transmissão do saber. Assim, o educando passa a ter uma imagem negativa da língua e de quem a ensina. Engana-se aquele docente que pensa ser o seu papel apenas o de destinador de um saber. Ser um educador-destinador implica não só um /saber-fazerl, mas um /poder-fazerl e ser competente a ponto de fazer o outro /fazerl, em especial nessa última modalidade, pois o educando perceberá a língua de outra forma e terá um desempenho melhor em sua aprendizagem. $O$ sujeito-aluno passará a ter um olhar que vai além do simples aprender um idioma, mas terá vontade e prazer em /querer-aprender/ e /saber/ cada vez mais sobre a língua e, dessa forma, ampliar sua visão de mundo acerca da língua e da cultura. A legitimação de um saber lingüístico só será percebida pelo educando quando ele sentir que, de fato, está aprendendo. 


\title{
CAPÍTULO II
}

\section{II- CONSIDERAÇÕES SOBRE A TEORIA DA LINGUAGEM}

\begin{abstract}
Antes mesmo do primeiro despertar de nossa consciência, as palavras já ressoavam à nossa volta, prontas para envolver os primeiros germes frágeis do nosso pensamento através da vida, desde as mais humildes ocupações da vida quotidiana aos momentos mais sublimes e mais íntimos dos quais a vida de todos os dias retira, graças às lembranças encarnadas pela linguagem, força e calor.
\end{abstract}

(Hjelmslev, 1975, p. 1)

A linguagem é algo inato ao ser humano e nascemos "programados" como disse um dos discípulos de Chomsky (1985 apud LUFT, 59) - para aprender e exprimir os sentimentos por meio da fala ou dos gestos. Com o passar do tempo, a criança aprende a utilizar a fala e a observar os gestos no meio em que vive. O meio propicia o desenvolvimento intelectual dessa criança, ora corrigindo-a ora deixando-a livre em suas especulações lingüísticas. Segundo D.I. Slobin ${ }^{13}$, as crianças são lingüistas inconscientes; nascemos com a linguagem, com uma estrutura lingüística genérica, mas é a maneira como a utilizaremos e o que decidiremos fazer com ela, que nos fará pensar e agir de modo diferente.

O ser humano é o único ser que tem a capacidade de pensar o mundo e exprimi-lo por meio das diferentes linguagens. Segundo Chomsky (Apud LUFT, 1985, p.37), a linguagem é parte de nossa herança biológica e acrescenta:

${ }^{13}$ Id., Ibid., 1985 
[o] desenvolvimento da linguagem é um processo natural e espontâneo, um saber intuitivo, onde o idioma se desenvolve em nossas mentes quando somos colocados em um meio ambiente apropriado, passamos a desenvolver modelos lingüísticos para expressar o que sentimos e pensamos.

Desde que nascemos, passamos por várias experiências cognitivas. O indivíduo está em uma aprendizagem constante e a linguagem está sempre em transformação, conseqüentemente, em expansão. Os cientistas afirmam que o organismo vive em constante processo de interação com seu ambiente e que as relações que mantemos com o mundo são de dar e receber, ou seja, recebemos inúmeras informações e damos respostas também.

O cérebro é um órgão que não possui um sistema de funções fixas e imutáveis; é um sistema aberto, de uma plasticidade enorme, em que a estrutura e modos de funcionamento são moldados ao longo da história do indivíduo e da própria espécie. Dessa forma, estamos sempre em desenvolvimento, recebendo e reagindo aos estímulos, ao mundo que nos cerca e cabe ao educador estar consciente dessa grande flexibilidade cerebral que se encontra pronta para receber novas informações, combinálas e recombiná-las.

Em seus estudos, Saussure (1969) afirma que a língua é um sistema de signos. Usamos os sons para expressar nossas idéias e, quando escrevemos, usamos símbolos gráficos para comunicar essa mesma idéia. O signo, como sabemos, é a união de um significante com o seu significado e, da união dos dois, teremos uma função semiótica, uma significação. Esse signo lingüístico é arbitrário, ou seja, não há liame algum entre um significante e seu significado. Se usarmos um significante da língua inglesa, como cat, a seqüência de sons que ouviríamos não seria 
melhor do que falarmos no significante da língua japonesa, que será expresso ou traduzido por neko ou no italiano gatto, desde que a maneira de expressar essa palavra (graficamente ou verbalmente) seja aceita pelos membros da sociedade lingüística a qual pertencem.

O signo apenas seria menos arbitrário ou motivado no caso de onomatopéias, em que o som do significante parece ter um caráter mimético com o que é expresso na língua em questão, como em português teríamos o som que o gato produz "miau". Em algumas línguas, como por exemplo, no inglês, podemos dizer que o signo é parcialmente motivado, pois se escrevermos typewriter (type = tipos) e writer (algo que escreve), tal signo nos remeterá ao conceito de uma máquina de escrever, uma vez que encontramos aqui uma relação entre a seqüência sonora e seu conceito. Cada língua terá uma designação arbitrária para os conceitos dos objetos no mundo. Entretanto, a língua não se resume a uma lista de palavras que podemos verter de uma língua para outra, se fosse, aprender uma nova língua seria bem fácil.

Há casos como o verbo To know que significa em português tanto conhecer como saber, cobrindo duas áreas de significados da língua portuguesa ou o vocábulo saudades que em inglês seria miss e esse mesmo vocábulo cobre um outro significado na língua inglesa como em to miss a chance (perder uma oportunidade), dentre outros. Ou então, em casos como nos verbos To win, To earn e To get que, em português, teriam o mesmo significado que é ganhar, mas em inglês seriam usados em situações totalmente distintas e assim por diante.

Algumas vezes não existe uma tradução para um determinado termo ou conceito, apesar dos graus de equivalências que existem entre as línguas. Se pensarmos que o conceito de neve para um esquimó é uma questão de sobrevivência e, por isso, ele nomearia diferentes tipos de 
neve, não poderíamos ser capazes de compreender tais diferenças sem que tivéssemos vivenciado os diferentes tipos. Como vivemos em um país tropical, não precisaríamos nomear ou conceituar esses diferentes tipos de neve, pois está muito distante de nossa realidade. Assim sendo, teremos uma visão de mundo diferente dos esquimós e cada língua terá uma organização de mundo diferente.

Os significados também são conceitos que se modificam com o passar do tempo e são contingentes, variando de uma língua para outra. Culler (1976, p. 17) diz o seguinte a esse respeito:

[...] a história das línguas está repleta de exemplos de conceitos que trocam, que mudam suas fronteiras. A palavra inglesa cattle, por exemplo, num determinado momento, significou propriedade em geral, depois gradualmente foi-se restringir a apenas à propriedade de animais quadrúpedes (uma nova categoria) e finalmente chegou a seu sentido moderno de bovinos domesticados.

Outro aspecto do fenômeno lingüístico, demonstrado por Saussure ( 2004 , p. 17), durante seus cursos, foi a relação entre o plano da língua e o plano da fala. Sobre a língua ele afirma:

É ao mesmo tempo um produto social da faculdade da linguagem e um conjunto de convenções necessárias adotadas pelo corpo social para permitir o exercício dessa faculdade nos indivíduos.

Então, teremos na língua uma convenção social, o patrimônio de uma cultura que evolui e sofre contínuas transformações através dos tempos, conforme mencionado anteriormente. Enquanto a fala é uma realização concreta não virtual ou psíquica, ou seja, é a maneira pessoal de utilização do código. Saussure (2004, p. 27) comenta o seguinte sobre língua e fala: 
[...] a língua é necessária para que a fala seja inteligível e produza todos os seus efeitos; mas esta é necessária para que a língua se estabeleça; historicamente, o fato da fala vem sempre antes. Como se imaginaria associar uma idéia a uma imagem verbal se não se surpreendesse de início esta associação num ato de fala? Por outro lado, é ouvindo os outros que aprendemos a língua materna; ela se deposita em nosso cérebro somente após inúmeras experiências. Enfim, é a fala que faz evoluir a língua; são as impressões recebidas ao ouvir os outros que modificam nossos hábitos lingüísticos. Existe, pois, interdependência da língua e da fala; aquela é ao mesmo tempo o instrumento e o produto desta. Tudo isso, porém, não impede que sejam duas coisas absolutamente distintas.

Apesar de não haver um liame entre significado e significante, pelo fato de os signos lingüísticos terem sido convencionados pelos membros de uma sociedade, quando ensinamos um idioma, precisamos dar sentido a ele, construindo um sentido para algo que antes não tinha significado para um indivíduo de cultura distinta, apontando suas diferenças e o modo pelo qual a cultura articula seus conceitos e classifica-os. O referente no mundo real será importante para chegarmos à significação de uma língua. Considerando a observação lingüística do signo, mesmo que seja arbitrário, faz-se necessário colocar esse signo dentro da organização a que pertence, pois ele nasce e desenvolve-se dentro de tal organização.

Nesse sentido, o signo só pode ser pensado socialmente e dentro de um contexto. Tanto as palavras quantos os gestos nascem neutros, mas ao serem contextualizados passarão a ter valores, conceitos. Aprendemos esses valores por meio do contato social, da troca, criando assim a nossa própria consciência da linguagem. Dessa forma, devemos ter em mente, também, a maneira de transmitir uma língua estrangeira, que vem carregada de valores, modos de pensar e agir. Afinal, como diz Barthes, o código lingüístico é um instrumento de "pensar o mundo" e Pais (1977, p. 21) faz o seguinte comentário: 
Por meio dele [código lingüístico] o homem integra todos os dados de sua experiência num universo e se integra ele próprio nesse universo assim criado, que não é a cópia, a reprodução ou tradução fiel mas antes uma visão particular dele, como grupo e, até certo ponto, como indivíduo.

\subsection{Uma breve reconstrução da aquisição de linguagem e do fenômeno lingüístico}

A linguagem é o reflexo de tudo aquilo que o sujeito experienciou, aprendeu com o outro durante sua vida. Nos primeiros anos de vida, o homem tenta "identificar", à sua maneira, o que está ao seu redor, assim ele tenta dentro de um raciocínio ou inteligência prática ${ }^{14}$, segundo uma acepção Vygotskyana (2002 apud OLIVEIRA, p.44), compreender o novo. Algo intrapsicológico ocorre nesse sujeito desde o início e amadurece com o tempo. Esse "algo" que estava amorfo toma uma forma, até mesmo antes de balbuciar os primeiros sons. Aquele universo intrapsicológico que se forma está muito além de nossa compreensão, mas sabemos que ocorrerá em qualquer criança, sem distinção de sexo, classe, cultura e história, algo que, segundo Chomsky (1985 apud, LUFT, p.59), é inerente ao ser humano e biologicamente determinado, fazendo parte da herança genética do homem.

Sabemos que a criança nasce com capacidade para adquirir a linguagem. Tal aquisição é um raciocínio silencioso que começa a associar as "coisas" e interagir com o meio, com as pessoas que a rodeiam e tanto esse meio quanto as pessoas influenciam e interagem com essa criança. Essa criança manipula o meio e as pessoas sem saber, pois existe algo que está gravado em algum lugar de seu inconsciente e que faz com que ela experiencie diferentes ações, sem que essas ações tenham sido manipuladas ou estabelecidas pelo meio; é a natureza que age por si

\footnotetext{
14 Segundo Oliveira, a inteligência prática seria "a capacidade de solução de problemas e de alteração do ambiente para obtenção de determinados fins".
} 
mesma, incitando essa criança a jogar inúmeras vezes um brinquedo fora do chiqueirinho ou percebe que chorar fará a mãe pegá-la no colo, alimentá-la ou, simplesmente, trocá-la.

Com o tempo, a criança aponta para algo, mesmo sem saber o significado desse gesto, mas é respondido prontamente pelo adulto, pois o apontar torna-se um gesto para o outro. O que era um movimento de apontar sem significação, transforma-se-a em um ato de apontar que a criança observa e infere nessas pequenas ações. Assim, começa a estabelecer uma comunicação com o que a cerca, tecendo as primeiras significações sobre os objetos, bem como de seus próprios gestos. O movimento é compreendido, pouco a pouco, pela criança e estabelece relações, ou seja, o processo interpessoal é transformado em intrapessoal.

Desde muito cedo, a criança é observadora e vai discriminando primitivamente esse mundo que a rodeia. Muitas informações são recebidas no dia-a-dia e uma operação que, inicialmente, representa uma atividade externa, é reconstruída e internalizada, toma forma e constrói uma história, estabelecendo ligações entre ela e o mundo. Diante disso, amadurece cognitivamente e, com ajuda desse meio, a criança é levada a construir uma atenção voluntária, uma memória lógica e a uma formação de conceitos. A internalização das formas culturais de comportamento envolve uma reconstrução psicológica, que tem como base as operações com os signos, sendo que o mesmo ocorre com a fala externa e egocêntrica que serão a base para a fala interna ${ }^{15}$.

De acordo com Bloomfield (1972 apud BUYSSENS, p.40), a significação é feita na observação de uma situação social estabelecida

\footnotetext{
15 Segundo Oliveira (2002, p.52), fala egocêntrica ou discurso egocêntrico é o "discurso da criança que dialoga consigo própria, quando fala sozinha (ou pensa alto)". Já o discurso interior ou fala interior é uma forma interna de linguagem, um diálogo consigo mesma sem vocalização, voltada para o pensamento, tendo a função de ajudar um indivíduo nas suas operações psicológicas.
} 
entre falante e ouvinte e, dessa maneira, a criança aprende a falar pelo fato de estabelecer uma relação entre o que ouve e a situação social que está ouvindo. Todos os movimentos sistemáticos, a percepção, o cérebro, o organismo inteiro está recebendo inúmeras informações, reagindo a elas, mas de forma organizada dentro de estágios específicos tanto em grau de desenvolvimento orgânico quanto pelo grau de domínio no uso de instrumentos, assim, o mundo passa a ter sentido e significado.

Buhler (2000 apud, VYGOTSKY, p.28) diz que a gênese do desenvolvimento cognitivo se encontra numa "inteligência prática" ou raciocínio técnico, que é anterior à fala, mas é a partir dessa integração entre fala e raciocínio prático que permeará a história do indivíduo ao longo de seu desenvolvimento; dessa maneira, o ser humano tenta identificar o que está ao seu redor. A experiência social no desenvolvimento desse sujeito implica o seu desenvolvimento e essa experiência exerce seu papel por meio do processo de imitação. Nesse sentido, a criança observa o adulto no uso de instrumentos e repete.

Com o passar do tempo, essa criança terá uma série de imagens de como manipular o objeto, compreendendo, assim, sua utilidade; os modelos que foram cristalizados em sua mente servem para outras situações no futuro. Quando a criança inicia seus estudos, em uma instituição de ensino, ela começa a estabelecer idéias e inferir sobre o mundo, sobre as coisas que a cercam, formando conceitos que, até então, eram experienciados de forma distinta ao vivenciado com seus pais. A escola passa a ter o papel de elemento socializador, é um local de transferência de "novos saberes" acerca do mundo.

Entre $01^{\circ}$. e $2^{\circ}$. anos de vida, essas crianças já percebem que existe uma relação dos objetos com seus significados e, conseqüentemente, os "sons" passam a ter uma nova organização em seu comportamento, sendo que o falar passa a ser um elemento mediador entre o meio e o querer do 
indivíduo, o qual produz novas relações com esse meio e uma nova reorganização no agir com o que o cerca (as atividades externas são reconstruídas internamente). A fala surge espontaneamente e desenvolvese cada vez mais. A criança começa a perceber o mundo não somente pelos sentidos, mas também pela fala. Com o tempo, a fala torna-se um elemento essencial no desenvolvimento dessa criança. A significação, segundo Eric Buyssens (1972, p. 41),

[...] é a influência que procuramos exercer, recorrendo a um meio convencional; é um fato social e é precisamente isto que nos permite conhecê-la muito melhor do que o pensamento individual.

É certo que só podemos captar a significação com o auxílio de formas, lingüísticas ou de outra natureza, mas nós a captamos.

O fato de estabelecermos assim uma equivalência entre duas frases, ou entre uma placa [é proibido estacionar] e uma fórmula lingüística, permite-nos atingir a significação.

A percepção, a fala e a ação provocam uma internalização das situações que cercam esse indivíduo, possibilitando a ele aprender cada vez mais com tais situações. Desse modo, as possibilidades de ação no meio são bem maiores, realizando tarefas cada vez mais complexas e podendo planejar ações futuras. A fala egocêntrica, nos primeiros anos de vida, ajudará a criança a planejar uma forma de solucionar problemas e executar uma solução mais elaborada por meio de uma atividade visível. Se pensarmos que todo esse processo ocorre de uma forma natural no 
indivíduo, nada mais lógico que o educador dê continuidade a esse processo de forma natural, também.

Se analisarmos o processo de aquisição de uma língua estrangeira, teremos também a formação de um sentido, entretanto, utilizaremos de outras linguagens (verbais, não-verbais e sincréticas) para termos um respaldo técnico e metodológico na construção desse sentido na aprendizagem da L2. Quando ensinamos uma língua natural, temos sempre em mente o sistema a que essa língua pertence, uma vez que tal sistema é regido por leis internas, isto é, de ordem sintático-semântico, fonético-fonológico, morfológico e lexical. Com relação ao léxico, vale ressaltar o que Biderman (1978, p. 139) diz:

\begin{abstract}
O Léxico de qualquer língua constitui um vasto universo de limites imprecisos e indefinidos. Abrange todo o universo conceptual dessa língua. Qualquer sistema léxico é a somatória de toda a experiência acumulada de uma sociedade e do acervo da sua cultura através das idades. Os membros dessa sociedade funcionam como sujeitosagentes, no processo de perpetuação e reelaboração contínua do Léxico da sua língua. Nesse processo de desenvolvimento, o Léxico se expande, se altera e, às vezes, se contrai. As mudanças sociais e culturais acarretam alterações nos usos vocabulares, daí resulta que unidades ou setores completos do Léxico podem ser marginalizados, entrar em desuso e vir a desaparecer. Inversamente, porém, podem ser ressuscitados termos que voltam à circulação, geralmente com novas conotações. Enfim, novos vocábulos, ou novas significações de vocábulos já existentes, surgem para enriquecer o Léxico.
\end{abstract}

Dessa forma, percebemos que a língua é algo dinâmico, sempre em transformação; é um sistema aberto que está pronto para ser realimentado e reelaborado continuamente pelo indivíduo. São os falantes que mantêm esse sistema lingüístico ativo, que o conservam e criam também, e são eles que agem sobre a estrutura do léxico, atribuindo conotações particulares aos lexemas, alterando significações na sua língua, no universo semântico. 
Quando falamos em aquisição de linguagem, estamos falando de uma aprendizagem que não cessa durante toda a vida de um indivíduo, sendo sempre categorizada, de acordo com as experiências vivenciadas, ampliando-se com o tempo, uma vez que o universo lingüístico desse sujeito está sendo alimentado por oportunas experiências. Esse universo lingüístico compreende o universo semântico - que, por sua vez, é dividido em universo semiológico e semêmico - e o universo lexical.

Com o tempo, o indivíduo incorpora um sistema de regras, não só gramaticais (sistema fechado), mas fonológicas também e um acervo lexical (sistema aberto). Tudo é armazenado e classificado em nossa memória, pronto para ser atualizado em discursos. Logo, um aprendiz da L2 precisaria adquirir um acervo lingüístico suficiente para poder ser capaz de comunicar-se.

Assim sendo, um indivíduo apenas produz à medida que algo toma forma para ele e que começa a fazer sentido. O que antes estava amorfo passa a tomar forma, notadamente, quando está relacionado com o mundo real (elementos extralingüísticos) e a fala concretiza o que vem sendo registrado no sistema virtual. Tanto 0 ato escrito como o oral serão manifestações de uma atividade formal que foi sendo desenvolvida por meio de uma prática constante e de uma exposição do sujeito a materiais escritos e falados.

Isso posto, entendemos que o léxico de uma língua, por pertencer a um sistema, segue as regras combinatórias de sons, palavras ou grupo de palavras daquela cultura que irão significar aquilo que o sistema determina por meio de uma norma e que, posteriormente, será manifestado na fala ou na escrita.

Nesse sentido, convém lembrar o conceito de Sistema, Norma e Fala que E. Coseriu reformula, a partir da dicotomia Saussuriana sobre língua e 
fala: sistema é a estrutura da língua que contém elementos indispensáveis, ou melhor, as oposições funcionais do sistema que "asseguram o seu funcionamento como instrumento cognoscitivo e de comunicação" (COSERIU, 1979: 96), enquanto a norma, que contém o sistema, é "um sistema de realizações obrigatórias de imposições sociais e culturais que varia segundo a comunidade lingüística" (1979: 98). A fala é o ato lingüístico que é realizado pelo falante de um idioma. Assim como Coseriu, Biderman (1978, p.18) diz o seguinte a respeito dos diferentes tipos de normas existentes:

(...) existe uma norma geral - a da sociedade global ou da nação - e as normas parciais, regionais, ou as normas dos grupos minoritários dentro da comunidade. Por outro lado é preciso reconhecer a presença da norma nos diferentes níveis de análise lingüística: fonético, morfológico, sintático e léxico.

Todavia, é possível que a norma seja violada, não só por artistas (por questões estéticas), mas por razões de adequação de linguagem (linguagem familiar, coloquial ou popular) ou, então, pela necessidade de buscar um outro tipo de expressividade e, outros, simplesmente preferem ignorar as normas de uma dada língua ${ }^{16}$. Além disso, o falante manifesta a sua individualidade por meio da fala (idioleto).

Aprender uma nova língua não precisaria ser sinônimo de angústia, como acreditam alguns discentes. O professor-educador precisa criar condições, instrumentalizando e estimulando o seu educando, fazendo-o utilizar suas capacidades internas e inatas e a tecer relações entre os 'elementos correlatos', que facilitam a construção do saber lingüístico. Logo, não precisará decorar regras, frases ou lista de palavras para alcançar seu objeto de valor. Quanto mais expomos o indivíduo a modelos diversos, mais o capacitamos para compreender a estrutura interna da L2. Sendo assim, capacitamos o educando a exprimir-se em contextos

$16 \quad$ Id., ibid.,p.23 
diversos, mas não devemos esquecer das necessidades colocadas pelo educando, no início do curso, além de seu perfil e outros saberes que ele tenha aprendido e/ou que seja de seu interesse.

As diferenças individuais devem ser consideradas pelo educador, que precisa estar atento ao planejamento de suas aulas, sendo elas em grupo ou individuais, pois trabalhar com o outro, é trabalhar com suas idiossincrasias, portanto maneiras diferentes de recortar, ver o mundo (designata) e produção de modelos mentais (conceptus) diferentes, também. Estamos falando aqui do patamar da conceptualização que compreende o conceptus e designata (verificada na enunciação de codificação), a partir da percepção biológica que também é filtrada culturalmente, devido não só aos comportamentos e condicionamentos adquiridos, mas também, aprendidos, dentro da comunidade a que ele pertence.

Platão, no seu livro República (informação verbal) ${ }^{17}$, reconhece as diferenças existentes entre os indivíduos e a necessidade de escolher para cada um a ocupação que melhor corresponda às necessidades de cada pessoa. De maneira análoga, o educador deve ter em mente essas diferenças e adequar sua metodologia ao educando, ou noutros termos, cada pessoa apreende o mundo de uma maneira; em vista disso, adequamos o método à pessoa, levando em conta o 'tempo interno' desse indivíduo e sua história, assim, chegaremos a resultados diferentes para cada educando.

Quando uma língua é ensinada, o docente deve pensar em uma maneira de simplificar sua explicação ao mesmo tempo em que essa explicação deve ser bem clara, já que um outro código lingüístico está sendo usado, o que dificulta ainda mais o entendimento do educando;

\footnotetext{
17 Anotação das aulas de Epistemologia e Metodologia das Ciências Humanas, ministradas pelo Prof. Dr. José Jeremias de Oliveira Filho na Faculdade de Filosofia da Universidade de São Paulo, em 2003.
} 
portanto, devemos nos colocar no lugar do educando e observar suas feições que são indicadores do que ocorre no processo de aprendizagem desse indivíduo. $\mathrm{O}$ educador precisa estar atento à atitude do educando $\mathrm{e}$ identificar na expressão corporal dele uma indicação de dúvida ou falta de compreensão que o impede de acompanhar a explanação, considerando que, algumas vezes, o discente não faz perguntas quando tem dúvidas, e parece ao educador ter o educando entendido tudo o que foi explicado.

Diante desse quadro, é necessário fazer perguntas ao educando sobre o que foi explanado para que haja a confirmação do entendimento de um dado conteúdo lingüístico. Por essa razão, não devemos tornar as explicações ininteligíveis, ao contrário, devemos encontrar uma forma de ensinar, adaptando o vocabulário no discurso pedagógico, utilizando palavras que sejam de conhecimento do educando, ou seja, uma metalinguagem acessível, além de outras semióticas-objeto que levem o educando a entender o que está sendo explicado. Desse modo, o sujeitoaluno não se sentirá frustrado ou desmotivado.

A metalinguagem, a que nos referimos anteriormente, ajudará com a língua em estudo, pelo fato de essa utilizar sinônimos ou parassinônimos para simplificar uma explicação. Assim, evitaremos que o educando fique tenso ou confuso com as explicações, além de não querermos que ele volte a acreditar naquela idéia de ser incapaz de aprender, já que não consegue acompanhar o que o educador the ensina. É comum alguns educandos sentirem-se constrangidos ao fazerem perguntas numa aula em grupo e, provavelmente, desmotivarem-se, por não conseguirem compreender as aulas e, conseqüentemente, a participação em sala de aula será cada vez menor. Essa atitude do educando poderá ser um dos motivos da ausência de alguns deles da aula e, em outros casos, o afastamento do curso. 
Em contrapartida, há educandos que preferem lidar com suas dificuldades como um desafio e como parte do processo de aprendizagem. Outros preferem apenas comparecer às aulas, pois a companhia está pagando ou porque precisam de um saber lingüístico para a inserção no mercado, contudo, não participam da aula ou se esforçam em seu processo de aprendizagem. Não são raras as vezes que a barreira com a língua pode ser ativada ou reforçada pela dificuldade que esse discente sente para conseguir uma inserção no mercado. Sendo assim, o educando começa a acreditar que a língua inglesa é algo impossível de aprender e que impossibilita o seu crescimento profissional, conseqüentemente, acaba por desgostar dela ou até mesmo odiar, criando uma antipatia. Assim, o educador precisará ficar muito atento ao seu discurso também para não causar ou não amplificar ainda mais a insegurança de seu educando com relação à língua inglesa.

Notamos que aquilo que o sujeito-aluno desgosta é geralmente causado por um mal-estar que foi estabelecido num ambiente de sala de aula. Quando o educador faz bom uso de sua prática pedagógica e do seu discurso, ele acabará cativando o educando e o trará mais próximo do Ov, envolvendo-o e fazendo-o /querer-saber/ cada vez mais sobre a L2. Esse tipo de manipulação, por meio da sedução, exerce uma grande influência no processo de aprendizagem do educando e provoca nele o desejo de ir além e participar ativamente de sua formação, levando-o também a desenvolver cada vez mais sua competência e perfomance lingüísticas.

Essa relação entre educando e educador está além das técnicas e métodos, o que temos é a coexistência de uma aprendizagem prazerosa, amparada generosa e humanamente pelo professor-educador, propondo um caminho para o novo saber sem ressentimentos, e, assim, poderemos nos aproximar desse educando, pois sabemos ouvi-lo e respondemos às suas expectativas e necessidades. Se perguntarmos ao educando o motivo 
de ele gostar mais de uma determinada aula do que de outra, provavelmente, ele responderá que aquela aula em questão era mais divertida, pois conseguia participar mais e sentia-se aprendendo. Uma aula dinâmica e divertida, na qual o educador é solícito e sensível diferentemente daquele docente do seu passado - terá um educando mais próximo e este, sem dúvida, poderá sentir-se melhor e mais à vontade com aquele perfil de seu novo educador e, conseqüentemente, com a língua inglesa.

\subsection{O processo da comunicação}

Estamos sempre nos comunicando através não só das palavras, mas também dos gestos, das nossas feições e interagimos com o que nos cerca. Quando somos crianças, relacionamo-nos com o mundo de forma natural, somos levados pela curiosidade a perceber o mundo e entendê-lo, construindo-o paulatinamente. Tudo é novo, instigante, interessante e almejamos saber cada vez mais, mesmo que inconscientemente.

Comunicar é algo natural, mas com o tempo perdemos essa naturalidade pelo que a sociedade determina, acabamos por nos tornar mais rígidos conosco e com os outros, o que significa dizer que interagir não é algo tão fácil, em especial, quando nos deparamos com o novo, pois estamos automatizados, conseqüentemente, aprender tornar-se-á mais difícil para o adulto. Regras são determinadas pela sociedade e devem ser seguidas para sermos aceitos e inseridos num determinado mercado ou numa determinada ideologia. Voltar a estudar não é uma tarefa fácil para o adulto, sobretudo se ele tiver tido experiências anteriores insatisfatórias ou angustiantes com a língua inglesa. Alguns docentes parecem esquecer a necessidade de mantermos uma ressonância empática e um 'olhar 
sensível' com o seu educando, o que será também um determinante para o bom aproveitamento do curso.

A linguagem é o reflexo de tudo aquilo que o sujeito experienciou e aprendeu com o Outro, durante sua vida; o ensino de língua não foge à regra, ou melhor, ele precisa do Outro, ou seja, de uma alteridade para uma interlocução, uma ponte com a nova língua e o sentido que ela vincula. Em principio, o educador é o mediador desse processo, pois ele irá transmitir o novo saber ao sujeito-aluno, ensinando uma maneira de ler um outro universo lingüístico. Com o passar do tempo, o próprio educando deverá encontrar meios para manter a língua estrangeira ativa, atualizando o saber lingüístico adquirido.

Isso posto, pensemos no processo lingüístico de um remetente que envia uma mensagem ao seu destinatário. Essa mensagem está inserida em um contexto e é transmitida por um código comum ou parcialmente comum e finalmente teremos um contato, físico ou psicológico, entre os interlocutores. Esse processo os capacitará a entrarem e permanecerem em comunicação, ou seja, a manterem uma comunicação eficiente. Entretanto, se os signos lingüísticos não forem codificados claramente, teremos uma quebra na mensagem e, conseqüentemente, a perda de sentido na comunicação. Então, Jakobson esquematiza da seguinte maneira a comunicação entre interlocutores:

\begin{tabular}{|c|c|}
\hline & CONTEXTO \\
\hline REMETENTE $\ldots \ldots \ldots \ldots \ldots \ldots \ldots$ & MENSAGEM.......................... \\
\hline & $\begin{array}{c}\text { CONTACTO } \\
\text { CÓDIGO }\end{array}$ \\
\hline
\end{tabular}

Figura 3: Esquema da comunicação de Jakobson ${ }^{18}$

18 Jakobson (1969, p.23) 
E Jakobson (1969, p. 23) comenta o seguinte sobre o processo de comunicação:

Um processo de comunicação normal opera com um codificador e um decodificador. O decodificador recebe uma mensagem. Conhece o código. A mensagem é nova para ele e, por via de código, ele a interpreta. (...)

É a partir do código que o receptor compreende a mensagem.

Pais (1977, p.12) acrescenta a esse processo, o seguinte:

Para atender às necessidades de comunicação do homem com seu interlocutor, consigo mesmo e com o mundo que o envolve, para permitir-lhe integrar os dados da experiência num universo coerente, é preciso que um sistema de significação seja capaz não somente de estabelecer uma significação no processo sintagmático do discurso e veicular, desse modo, uma informação, mas também que possa gerar novas relações de significação, produzir novas grandezas e mesmo novas leis combinatórias, tornando possível, assim, a reformulação de uma visão do mundo.

O código referido no esquema acima representa a língua (código falado ou escrito), e ela seria, fundamentalmente, um instrumento de comunicação como afirma Saussure (1969). Esse código lingüístico possui uma estrutura que é constituída por um conjunto de elementos (fonemas, lexemas, grafemas) e uma combinatória de regras (sintáticas e morfológicas). Então, se a semiótica é uma ciência que estuda a estruturação de qualquer sistema de signos, poderíamos olhar para esse código como um sistema lingüístico, ou seja, como um sistema de signos que são destinados a transmitir uma informação ou uma mensagem a 
alguém, código esse que foi estabelecido por convenções de uma dada sociedade.

Dessa forma, teríamos um emissor ou um destinador que envia uma mensagem por meio de um código lingüístico ao seu receptor ou destinatário. Se o código for comum ou parcialmente comum aos dois sujeitos envolvidos nesse processo, a comunicação terá se estabelecido, mas se eles tentarem se comunicar por códigos distintos não poderão ser compreendidos, ou haverá perda de informação, mesmo que seja usada uma linguagem gestual, a qual também deve ser comum às duas culturas.

Assim sendo, para que ocorra a transmissão de uma mensagem, o sujeito-emissor precisa ter a faculdade de operar uma codificação (construir uma mensagem), e o sujeito-receptor, de decodificar a mesma mensagem (reconhecimento e identificação de elementos constitutivos da mensagem em questão) e o processo inverso será válido para ambos. Nesse percurso, há sempre filtros que, por mais que tenhamos o mesmo código lingüístico, sempre teremos uma perda de informação que poderá ser maior ou menor, dependendo também do acervo lingüístico e cultural do indivíduo. O educando tentará traduzir a nova informação, contudo, ele poderá elaborá-la de maneira correta ou não, pois depende da maneira que ele irá interpretar o que the é ensinado. De qualquer forma, ruídos podem interferir na nossa comunicação, sejam eles de ordem física (um ruído), psicológicas (o desinteresse, o cansaço) ou culturais (falta de conhecimento, códigos ou subcódigos distintos).

Vejamos o seguinte esquema:

\section{CÓDIGO LINGÜÍSTICO}

EMISSOR/DESTINADOR

Mensagem RECEPTOR/DESTINATÁRIO

CANAL

Figura 4: Esquema elementar do processo de comunicação 
Se transportarmos esse processo de comunicação que ocorre entre interlocutores da mesma língua ao processo de ensino-aprendizagem de uma língua estrangeira, teríamos de repensar em uma maneira de transmitir a mensagem, pois o educador utiliza-se de um código lingüístico (língua inglesa) e seu educando tem um conhecimento parcial ou nenhum sobre esse código. A mensagem não deverá vir carregada de informações minuciosas para não cansar e desmotivar o educando. Devemos ser objetivos e simples, sem complicar o conteúdo lingüístico a ser desenvolvido com ele, tornando assim, mais compreensível a explicação de um novo saber. Quanto ao canal - o contato entre emissor e receptor esse será um elemento importante nesse processo, pois é o que viabiliza o conhecimento da L2, auxiliando o educador a tecer relações com o novo saber lingüístico.

Entretanto, a dificuldade maior começa com o código, por esse ser distinto do que o educando conhece. $O$ educador utiliza-se de um código estrangeiro, pois esse é o objeto de estudo que será transmitido ao sujeitoaluno, então é preciso viabilizar esse código, bem como o percurso a ser feito para que o educando seja capaz de decodificar o que está sendo ensinado e, em seguida, possa codificar novamente a língua-objeto.

Entendemos que um processo da enunciação prevê duas instâncias inversas e complementares concomitantemente, ou seja, o processo de codificação que é realizado pelo sujeito enunciador de um discurso e o processo de decodificação realizado pelo sujeito enunciatário, sendo que esses sujeitos farão o percurso inverso. Nesse sentido, observamos, também, que o percurso gerativo de enunciação, proposto por Pais (1993), a partir do modelo de Greimas, considera que o percurso gerativo de enunciação de codificação tem seu início na percepção biológica, culturalmente filtrada e nas experiências, até a sua manifestação em 
discurso e, de forma inversa, teremos o percurso gerativo de enunciação de decodificação, que será reconstruído a partir dos textos manifestados. A respeito desse modelo de percurso gerativo, Pais ( 2006, p.146) comenta:

\begin{abstract}
Nosso modelo de percurso gerativo da enunciação de codificação e de decodificação, compreende os patamares da percepção, da conceptualização, da semiologização, da lexemização, da atualização, da semiose, quanto ao fazer persuasivo, do sujeito enunciador; os do reconhecimento da semiótica-objeto, da ressemiotização, da ressemiologização e da reconceptualização, quanto ao fazer interpretativo, do sujeito enunciatário; $e$ as transformações que eles realizam.
\end{abstract}

O repertório de um indivíduo é variável (rede de referências, valores e conhecimentos históricos, culturais, afetivos, profissionais, religiosos, dentre outros); esse repertório muda, também, de indivíduo para indivíduo e de comunidade para comunidade. Isso deve ser uma preocupação do enunciador-destinador quanto ao saber lingüístico, pois saber somente o código lingüístico não é o suficiente. Antes de comunicarmos algo, devemos pensar com quem nos comunicamos e qual é o repertório dessa pessoa a quem enviamos uma mensagem, tornando-a comum ao nosso destinatário-ouvinte. Segundo Blikstein (1986) "os termos comunicar e comunicação provêm justamente da palavra comum". As idéias, ou necessidades e projetos são levados ao conhecimento das pessoas, tornando-os comuns para que possamos obter respostas que correspondam a tais necessidades, idéias ou projetos do indivíduo. Quem fala quer comunicar algo e tenta, assim, influenciar o seu interlocutor, talvez por querer fazê-lo agir ou, simplesmente, para compartilhar seus sentimentos com ele. A esse respeito, Jakobson comenta:

Quando fala a um novo interlocutor, a pessoa tenta sempre, deliberada ou involuntariamente, alcançar um vocabulário comum: seja para agradar, ou simplesmente para ser compreendido ou, enfim, para livrar-se dele, 
empregam-se os termos do destinatário. A propriedade privada, no domínio da linguagem, não existe: tudo é socializado. (JAKOBSON, 1969: 23)

Para que um saber seja transmitido, temos de, necessariamente, observar o código lingüístico, uma vez que esse deverá vincular ao educando uma idéia ou conceito de uma outra língua; assim sendo, o educador precisa utilizar uma metalinguagem eficiente, sobretudo, a utilização dos 'elementos correlatos' para que o educando seja capaz de entender o que está sendo explicado. Não podemos esquecer que estamos tentando fazer que o educando aprenda um novo código lingüístico, por isso o educador precisará utilizar-se de outras semióticas-objeto para explicar e, assim, ser compreendido pelo sujeito-aluno. Esse sujeito traz consigo um conhecimento prévio da língua, pois estudou a L2 anteriormente, daí termos de fazer uma entrevista no primeiro dia de aula, os testes e as revisões que mostrarão o nível lingüístico do educando, bem como, questões de ordem cultural e histórica do indivíduo, auxiliando-nos num planejamento de aulas mais adequadas ao repertório lingüístico do educando.

A inteligência lingüística é de natureza humana, é o que nos diferencia das outras espécies, é a maneira pela qual expressamos o que sentimos e explicamos a nossa visão epistêmica acerca das coisas no mundo. Então, aprender uma língua não é complicado, complicado é não entender o que o educador não sabe como explicar ou transmitir. O educador tem, portanto, um material riquíssimo em suas mãos, ou seja, o sujeito-aluno; no entanto, saber o que fazer com o conhecimento que ele carrega consigo é que fará toda diferença no processo de aprendizagem daquele educando.

Ensinar uma língua é considerar o processo de comunicação de emissão e recepção de uma mensagem. Aquele que emite enunciados ou os escreve precisa, também, compreender o que é emitido ou escrito pelo 
seu interlocutor; desse modo, o educando precisa estar preparado para o papel tanto de emissor como o de receptor de enunciados, escritos ou falados, e o educador é o elemento principal dessa interlocução entre língua/pensamento e educando, é quem cria condições e estabelece relações na construção de um novo saber lingüístico, uma nova língua.

Se observarmos o conceito de signo lingüístico, definido a partir das idéias saussurianas, teremos o seguinte: imagem acústica (significante) e um conceito (significado), mas com o desenvolvimento da lingüística, o signo lingüístico sofreu algumas alterações e Hjelmslev passou a defini-lo por plano de expressão e plano de conteúdo que possuem uma relação de dependência designada função semiótica. Temos, então

\begin{tabular}{|c|c|}
\hline SAUSSURE & HJ ELMSLEV \\
SIGNIFICANTE & PLANO DA EXPRESSÃO \\
\hline SIGNIFICADO & PLANO DO CONTEÚDO \\
\hline
\end{tabular}

Figura 5 - Signo lingüístico (Saussure e Hjelmslev)

Quando escutamos ou lemos um enunciado em inglês, decodificamos o que aqueles signos lingüísticos significam dentro de uma cadeia frasal e de um contexto mais amplo. O sujeito, que emitiu ou escreveu esses enunciados em inglês, escolhe tanto uma estrutura de expressão como de conteúdo dentro das convenções lingüísticas da língua em questão, para se comunicar com o outro. Sendo assim, um sistema semiótico, nesse caso o lingüístico, é transmitido por meio do plano de expressão (falada ou escrita), relacionado ao seu plano de conteúdo (conceito, idéia).

As unidades mínimas do plano de expressão na língua falada são os fonemas que se combinam para formar unidades mínimas significantes, os 
monemas ou morfemas. Os fonemas possuem traços distintivos (femas) que devem ser analisados com o educando, pois cada língua possui um inventário de fonemas que lhe é próprio e que são combinados em sílabas. O simples fato de um sujeito-aluno não ter uma boa discriminação auditiva (percepção) e/ou uma boa articulação vocal (emissão) provoca ruídos na comunicação, notadamente quando os fonemas da L2 forem articulados erroneamente, podendo, por um lado, acarretar mudança de significado e, por outro, se forem mal articulados, provocar a incompreensão do que é dito. Além disso, os traços prosódicos ou supra-segmentais devem ser estudados também na L2, a saber: a entonação, os tons, o timbre, a intensidade, a altura, a quantidade, $\mathrm{o}$ acento e duração que são importantes para um bom desenvolvimento da emissão dos sons.

Quanto ao plano de expressão da língua escrita, devemos observar tanto os grafemas (letras) quanto os morfemas (lexemas e gramemas) levando o educando a perceber a maneira pela qual a língua articula na escrita, as palavras. Além da existência de um nível semântico, mencionado anteriormente, devemos levar o educando a entender $\mathrm{e}$ depreender de uma palavra traços significativos mínimos da língua inglesa, que ora mostram morfemas gramaticais (desinências), indicando tempo verbal, adjetivos, número, sexo, agente, ora gramemas (afixos) que precisam ser reconhecidos e ensinados ao educando para que ele possa legitimar a compreensão de um saber lingüístico.

Por essa razão, selecionamos exercícios que orientem o educando para um olhar mais atento às palavras em nível frasal e contextual, treinando a atenção do mesmo para as diferentes articulações da língua que, mesmo possuindo formas iguais (significantes iguais), possuem significados diferentes, em nível gramatical ou em nível lexical, como por exemplo, a palavra rope, que inserida em uma sentença poderá significar o substantivo "corda" ou o verbo "amarrar", além de palavras homônimas que 
têm a mesma forma, porém significados diferentes: book (substantivo) = livro e to book (verbo) $=$ reservar. Podem ocorrer também similaridades em nível fonológico, sobretudo, o que chamamos de minimal pairs ou palavras homófonas, pelo fato de possuírem formas diferentes e terem o mesmo som, por exemplo: air /er/ e heir /er/.

A discriminação dessas pequenas diferenças é uma condição sine qua non para a compreensão da L2, questões essas que podem ser ignoradas durante o processo de ensino-aprendizagem e, por isso, geram a incompreensão, uma vez que são formas confusas e causam ruídos na compreensão da L2 e, conseqüentemente, um distanciamento do objeto de estudo, acarretando uma desmotivação.

Apenas a compreensão do significante é que nos leva ao significado. Se um receptor não estiver familiarizado com uma palavra ou com o som que essa palavra emite, certamente esse indivíduo será incapaz de decodificá-la, ou seja, uma expressão na língua japonesa como, por exemplo, moshi-moshi será para um ouvinte apenas uma seqüência de sons estranhos diferentes das línguas inglesa e portuguesa e, para o leitor, será apenas uma seqüência de letras no papel. Mas, a partir do momento, em que ensinamos o som e/ou a grafia desse vocábulo demonstrado conjuntamente, por um gesto que lembra um telefone, uniremos as duas entidades, o significante e seu significado, ou como queiram outros lingüistas, uma expressão ao seu conteúdo, chegando, assim, a uma significação ou semiose.

A proposta do ensino de uma língua é fazer com que o educando chegue a comunicar seu pensamento pelo discurso escrito ou falado da $L 2$; todavia, essa proposta apenas será possível se houver um estudo dos elementos constitutivos de uma língua. Será necessário, também, uma explicação sobre os níveis de linguagem que ocorrem na língua inglesa, 
pois o adulto deverá ser capaz de comunicar-se tanto de maneira mais formal e técnica (reuniões de negócios) quanto num nível mais informal, dependendo da situação em que ele esteja inserido. Independente da escolha do educando, ele precisa estar ciente das diferenças desses níveis de linguagem, da mesma forma que ocorrem na língua portuguesa.

Nesse sentido, o educador precisa estar atento à forma que ele transmite uma informação ao educando, assim se ele usar um discurso muito técnico ou palavras que ainda não fazem parte do universo lexical do educando, acabará provocando um ruído na comunicação das informações e um esforço maior de entendimento por parte do educando. Como havíamos dito, a explicação deve ser simples e adequada ao nível e ao histórico daquele educando, pois com o tempo, o vocabulário será expandido e poderemos fazer uso de vocábulos mais rebuscados e técnicos.

A (re)elaboração de nosso discurso é algo a que devemos sempre prestar atenção, sobretudo, pelo fato de estarmos ensinando uma outra língua que se utiliza de signos diferentes; sendo assim, facilitamos o entendimento, ensinando a estrutura da língua inglesa de forma a não causar nenhum mal-estar no educando ou seu afastamento, já que uma grande parte de nossos educandos tentou estudar inglês em muitas ocasiões, entretanto, não obteve sucesso, justamente pela falta de explicação ou de métodos e técnicas que viabilizassem o entendimento da L2.

Convém ressaltar que, no início do curso, ensinamos ao educando a maneira pela qual ele poderia estudar a nova língua, dando-lhe sugestões para poder desenvolver-se por si mesmo; assim, estaremos dotando o educando de autonomia em seu próprio processo de aprendizagem. Nos primeiros dias de aula, costumamos dar alguns vocábulos ou expressões a 
serem utilizados durante o curso ou que ele encontrará nos livros didáticos, a fim de fazê-lo compreender alguns comandos que serão utilizados na aula ou enunciados em livros.

Assim, provemos o educando de uma maior segurança na compreensão do que está sendo explicado, mas todo esse vocabulário deve vir amparado por uma boa metodologia visual e gestual, para que, naturalmente, essas palavras comecem a fazer sentido para o sujeitoaluno, dando-lhe a possibilidade de criar relações entre as palavras e a ação, sem a necessidade de tradução, que só poderá ser feita, quando percebermos que o educando, a despeito de todos os esforços na explicação de algo, não consegue compreender o sentido.

O sentido somente poderá ser construído quando algo for internalizado pela experiência; não é apenas aprendido, mas apreendido pelo educando e, para que isso ocorra, faz-se necessário um /saber-fazer/ do educador, que procura atribuir um sentido ao que transmite. $O$ educando poderá ter um mundo semioticamente construído, dependendo da maneira que o educador construir as relações com o mundo natural e a língua. Por outro lado, se o docente não estiver preparado ou não for capaz de transmitir e gerar um saber lingüístico, provavelmente, causará um malestar em seu discente. É por do meio do discurso pedagógico que o educador tenta ensinar para o educando a $\mathrm{L} 2$, e, juntamente com o bom uso do material metodológico, ele conseguirá produzir a imagem mental de uma situação na $L 2$, levando o sujeito-aluno a tecer uma rede de significações de uma língua natural. Assim, teremos o seguinte esquema: 


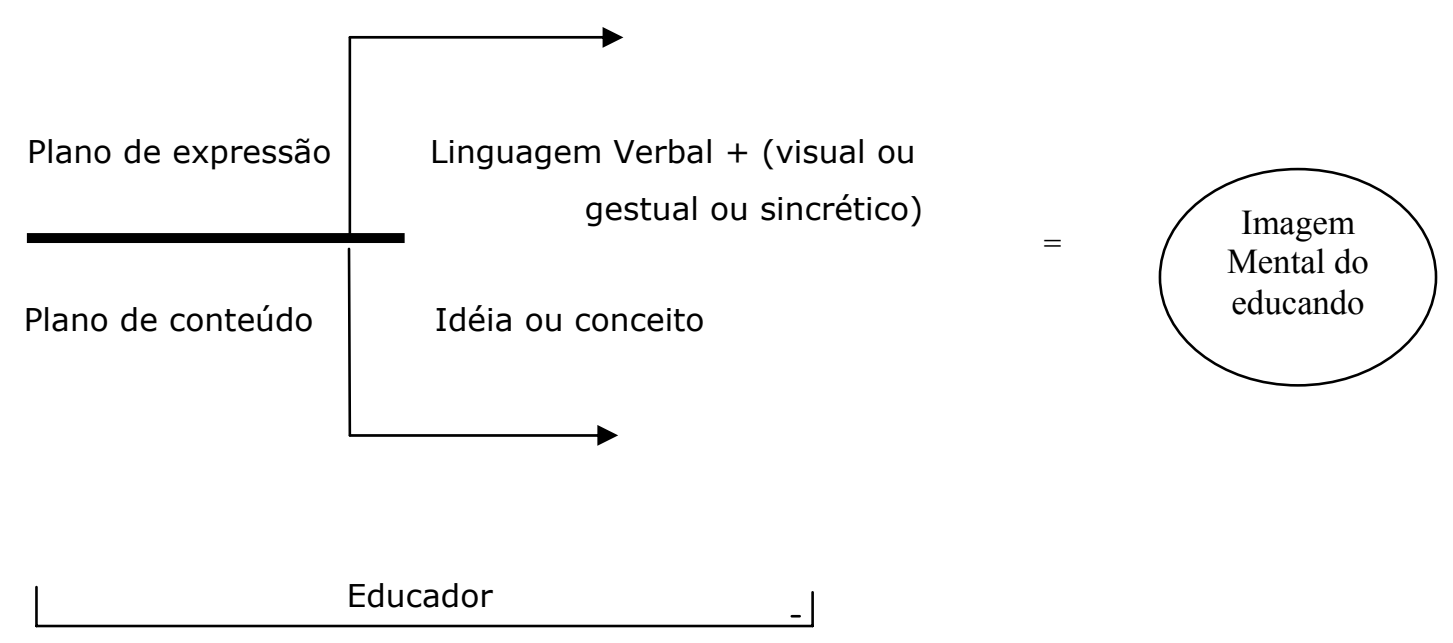

Figura 6 - Função semiótica aplicada ao ensino da L2

Sabemos que a língua é um instrumento de comunicação complexo e dinâmico. $\mathrm{O}$ que o sujeito-aluno procura é a possibilidade de expressar-se em um outro código lingüístico distinto do seu. Ele precisa aprender a ler o mundo por meio de uma outra semiótica-objeto. Para tanto, a codificação/decodificação de uma outra língua só é instaurada quando ele dominar o código lingüístico da $\mathrm{L} 2$, ou seja, quando tanto o plano da expressão quanto o plano de conteúdo forem armazenados na memória do sujeito-aluno.

Para que o educando decodifique a língua aprendida, ele precisa reinterpretar uma seqüência de sons e/ou uma seqüência de letras para decodificar a mensagem dentro de um contexto específico. Se ele, no papel de ouvinte, reconhecer o estímulo acústico, compreenderá algo da mensagem; da mesma forma, se ele estiver no papel do leitor, também compreenderá os signos lingüísticos do texto escrito. Esse processo comunicacional não é unilateral, isto é, visto apenas do ponto de vista do receptor, pois assume também o papel de emissor dentro desse processo, visto que o sujeito precisará codificar esse mesmo código que está apreendendo para produzir suas intenções, valores, idéias, enfim, comunicar algo a alguém. 
Então, o mesmo ator (educando) assume papéis actanciais distintos, ora de emissor, ora de receptor; o mesmo sujeito assume dois percursos: um onomasiológico (do conceptual aos signos = produção de uma mensagem, a codificação) e, o outro, semasiológico que constitui o percurso inverso (interpretação da mensagem, a decodificação), processo esse considerado bilateral, para que ocorra uma comunicação com um outro ator (educador, cliente, outro educando). O primeiro percurso investiga as designações e o segundo, as significações.

É interessante notar que o educando, enquanto está aprendendo uma língua estrangeira, primeiro familiariza-se com a expressão escrita e a expressão oral de seu educador. Contudo, a expressão verbal do próprio educando e o reconhecimento da fala de outros interlocutores ocorrem posteriormente. Provavelmente, isso é devido ao retardo da ligação entre o significante e o significado de um signo lingüístico. Nesse caso, o educando precisará ter muito clara a imagem do objeto + imagem acústica em sua memória e o conceito que essa imagem vincula, para que ele possa chegar a uma semiose significativa, ou seja, a uma significação do que pretende exprimir (codificar) tanto na fala quanto na escrita e compreender (decodificar) o que escuta ou lê.

O discurso oral implica maior esforço na organização das idéias e uma correta utilização dos elementos lingüísticos para transmitir o conceito desejado, ou seja, o sujeito-aluno precisará pensar, em princípio, nas informações sintáticas, morfológicas, semânticas, fonológicas e lexicais ao mesmo tempo, até conseguir um equilíbrio entre essas camadas de conhecimento lingüístico da $\mathrm{L} 2$, que são otimizadas quando há um contato mais intenso com o seu processo de aprendizagem tanto para a sua performance oral/acústica quanto para a escrita/leitura. 
O educando, no papel de ouvinte, tenta reconstruir o que lhe é transmitido, ou seja, ele precisa perceber e reconhecer os signos que talvez ainda não tenham tomado forma em sua mente, mas por meio dos gestos do educador ou signos icônicos do que se pretende transmitir, o educando acabará assimilando melhor a explicação do seu educador; mesmo assim, o sujeito-aluno ainda terá dificuldades de entender outros falantes de língua inglesa, em razão do filtro fonológico e do seu nível de conhecimento lingüístico.

O tempo dedicado aos estudos da língua deverá otimizar os aspectos fonético-fonológicos, gramaticais, semânticos e lexicais desse educando, desde que cada sujeito envolvido nesse processo de ensino-aprendizagem faça cada qual o seu percurso, isto é, um gerando conhecimento, o outro empenhando-se e ambos trabalhando em um percurso de ensinoaprendizagem satisfatório, pautado na troca e no 'olhar sensível', sobretudo por parte do professor-educador, pois é ele que "orquestra" sua aula e leva - educando a modificar a relação dele com seu processo de aprendizagem.

Nesse contexto, tanto a expressão oral quanto a compreensão auditiva são incentivadas pelo educador desde o início do curso, pois a comunicação necessitará, como já dissemos, de uma codificação e decodificação da língua estudada, e um bom desempenho lingüístico depende disso. Dessa forma, a expressão escrita, as leituras e as pesquisas são feitas em casa pelo educando; essas atividades são uma extensão da sala de aula, portanto, na aula seguinte teremos a produção resultante daquilo que o educando estudou em sua casa, sendo avaliada pelo educador e discutida durante a aula. É importante que o sujeito-aluno compreenda a necessidade de trabalhar em seu próprio processo fora da sala de aula, pois o aprendizado de uma língua é alcançado por um fazer 
teórico e prático, e, assim, ele conseguirá adquirir um controle sobre as habilidades lingüísticas.

Por conseguinte, aprender uma língua significa observar as relações paradigmáticas (combinação dentro de um sistema de possibilidades de comunicação) e sintagmáticas (uma possível seqüência falada) que fazem parte do sistema da língua (características funcionais ou indispensáveis para a realização de uma língua que se encontra em nível abstrato ou virtual), conseqüentemente, teremos de observar a norma da L2, que são imposições sociais e culturais, variando de acordo com a comunidade, dentro da mesma comunidade e de indivíduo para indivíduo (nível abstrato que obedece ao sistema ao qual a língua se ancora e controla as realizações da fala) para chegarmos a um falar concreto de atualização da língua. Diante disso, podemos dizer que dominar uma língua implica aprender o seu sistema lingüístico, considerando os vários níveis: fonológico, morfológico, sintático, léxico e semântico. Esse domínio lingüístico demanda um tempo tanto interno (relacionado à maturação cognitiva do indivíduo) quanto externo (disponibilidade de tempo real de estudo para trabalhar a teoria e a prática da L2).

No ensino de línguas, o ato comunicativo só será possível, quando o receptor, nesse caso o educando, for capaz de identificar os novos signos lingüísticos, acessados a partir de uma experiência anterior, integrada ao novo sistema lingüístico. Por conseqüência, a informação é decodificada quando ele for capaz de entender o que seu emissor quer transmitir. Se, num primeiro momento, a experiência anterior for pouca ou inexistente, fazse necessário encontrarmos maneiras de podermos comunicar ao outro o que queremos por meio de uma metalinguagem acessível, recurso esse que será viabilizado por outras semióticas-objeto, quais sejam, verbais, não verbais e sincréticas. Assim, poderemos começar a fazer com que o educando passe a entender a $L 2$, sem que precisemos utilizar a $L 1$, afinal, 
quanto mais expusermos o educando aos sons e às estruturas lingüísticas da nova língua, mais rapidamente ele começará a incorporá-las.

Paulatinamente, vamos desenvolvendo no educando não só um "suporte", mas também um "aporte", que segundo Pottier (1977 apud, PAIS, p.76) são estruturas necessárias para que haja uma comunicação. Inicialmente, colocamos o sujeito-aluno em situação de "suporte", dandoIhe informações sobre a nova língua, permitindo uma familiarização com suas estruturas, por meio de outras linguagens e que o leve a compreender a explicação na L2, e, posteriormente, amplifica esse novo universo lingüístico, adquirindo informações suplementares a respeito da L2 que constituirá seu "aporte". Tal "aporte" conduzirá o educando ao nível desejado de comunicabilidade numa interlocução. Entretanto, um "suporte" que não esteja bem elaborado e estruturado não viabiliza a instauração de "aportes", uma vez que esses pressupõem um suporte bem estruturado e ativo na conceptualização da L2 pelo educando.

Em princípio, não existe uma intersecção entre os códigos lingüísticos. Temos um emissor (educador) que transmite um novo código lingüístico ao seu receptor (educando), que com o tempo, adquire competência para comunicar-se no mesmo código lingüístico, momento em que uma intersecção começa a ser possível e será amplificada, dependendo da maneira pela qual os sujeitos, envolvidos nesse processo, farão para conseguir chegar ao seu Ov. Temos, portanto, um educador com um saber lingüístico que não está em conjunção com seu educando, pois ele ainda não tem conhecimento da L2 ou tem um conhecimento parcial. Temos, o seguinte: 


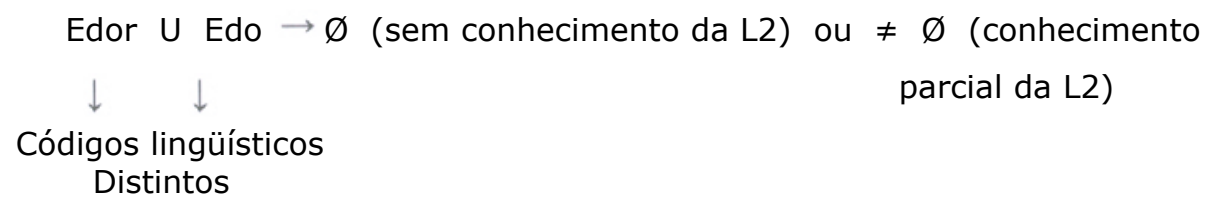

$$
\begin{aligned}
& \text { Edor }=\text { educador } \\
& \begin{aligned}
\text { Edo } & =\text { educando } \\
\cap & =\text { conjunção } \\
U & =\text { disjunção } \\
\rightarrow \quad & =\text { implica } \\
\varnothing \quad & =\text { conjunto vazio }
\end{aligned}
\end{aligned}
$$

Com o tempo, teremos uma intersecção, ou seja, uma conjunção entre o universo lingüístico do educador com seu educando, pois a rede de referências do universo antropocultural do educando irá ampliar-se aos poucos durante sua aprendizagem: Edor $\cap$ Edo $\neq \varnothing$

\subsection{0 ensino de língua estrangeira: breve histórico e aplicações metodológicas}

Sabemos que a necessidade de comunicação com falantes de culturas distintas é muito antiga. De acordo com Germain (apud Cestaro; doc eletrônico), as primeiras aprendizagens de uma língua estrangeira aconteceram pelo contato direto com o estrangeiro, embora alguns povos tivessem a preocupação em aprender e ensinar a língua estrangeira. Ainda segundo o autor, o ensino de uma língua estrangeira remonta à conquista dos sumérios pelos acadianos. Os acadianos adotaram o sistema de escrita dos sumérios e aprendiam a língua dos povos conquistados; da mesma forma os romanos também aprendiam a língua dos povos por eles conquistados. Além disso, há registros de manuais bilingües de ensino de línguas que datam do $3^{\circ}$ século de nossa era e enfatizam a prática do vocabulário e da conversação. 
No entanto, com o advento da $2^{\text {a }}$ guerra mundial, os soldados americanos deveriam aprender uma língua estrangeira num mínimo de tempo possível. Então, foi criado um programa didático chamado de "método do exército" ou método áudio-oral. Esse método baseava-se nos princípios da psicologia da aprendizagem (psicologia behaviorista de Skinner) e na lingüística distribucional de Bloomfield. Segundo Passel (1983), os resultados que foram obtidos de uma imersão em L2 devido ao programa didático do exército fizeram muitos pedagogos reformularem o conceito do que seria ensinar uma língua estrangeira. $O$ relatório elaborado pela Commission of Trends in Education of the Modern Language Association of America (1983, apud PASSEL, p.1) dizia o seguinte a respeito do ensino de línguas:

\footnotetext{
O objetivo do ensino de línguas é proporcionar ao aluno o domínio da língua falada na sua forma coloquial. Este comando inclui a capacidade de falar a língua fluente corretamente e com pronúncia bastante próxima à dos falantes nativos. Significa também que o aluno terá uma compreensão auditiva praticamente perfeita da língua tal qual é falada pelos nativos.
}

Para que os esforços empreendidos pelo exército americano dessem certo, seria necessário adquirir fluência de uma língua, visto ser importante para as missões que os soldados deveriam desempenhar na guerra, bem como a questão cultural, considerando que aprender uma língua sem ter noção de hábitos e costumes dos falantes nativos não teria valor algum.

A leitura de Passel (1983) sobre esse relatório descreve o tempo necessário para se conseguir o objetivo pretendido num período de 6 a 9 meses, dentro de um estudo dirigido de 15 horas semanais, acrescidas de horas de estudo livres. Portanto, teríamos um total de 480 horas, além das horas livres. Havia normas rígidas que os soldados precisariam seguir à risca, como as aulas mais teóricas (ensino da pronúncia, gramática, construção de frases e formação das palavras), ministradas pelo diretor do 
curso. Além disso, durante 6 vezes por semana, por duas horas consecutivas, um falante nativo (drill-master ou repetidor) fazia um exercício dirigido com os soldados, sob a supervisão do diretor do curso, em que era aplicado o conhecimento teórico na prática, ou seja, em exercícios intensivos de conversação.

Nessa época, não havia pesquisas comparativas entre o inglês e as línguas ensinadas para que pudessem ter uma base das dificuldades, que provavelmente os discentes da L1 (língua inglesa) encontrariam na L2 (língua estrangeira), cabendo aos diretores descobrir essas dificuldades e encontrar uma forma de ajudá-los, recorrendo a lingüistas eminentes para a direção de tais cursos. Os repetidores não precisariam ser necessariamente docentes diplomados; o objetivo era manter uma conversação na L2, sem ultrapassar os limites determinados pelo diretor do curso.

Os grupos tinham uma formação homogênea e continham 10 pessoas no máximo. Nas horas livres, os soldados deveriam sempre usar a L2, mesmo em ambientes distintos da sala de aula como no refeitório, no alojamento, nos corredores, além disso, assistiam regularmente a filmes, bem como participavam de conferências sobre o país de origem da língua estudada. Entretanto, havia uma severa seleção entre os soldados para que eles pudessem participar desses cursos. Eles deveriam ter no mínimo 22 anos, cursado universidade e demonstrarem por meio das certificações escolares serem possuidores de uma aptidão para a aprendizagem de línguas, ou seja, um certo grau de inteligência e competência que seriam levantados e avaliados pelo Army General Classification Test.

Passou-se, então, a difundir essa nova metodologia, sendo que, posteriormente, esse método foi aplicado em um programa normal de ensino de línguas, dentro de uma instituição de ensino. Contudo, essa situação era irreal para o sistema de ensino usual, em razão do número de 
discentes para cada docente e, além disso, a motivação desses estudantes era completamente diferente.

No caso dos soldados, compreender o mais rápido possível a L2 seria uma questão de vida ou de morte durante as missões no país estrangeiro, diferentemente do que encontramos em pessoas comuns que possuem objetivos distintos. O fator tempo e o local trariam um outro problema, já que, em escolas regulares, não seria possível recorrer a esse tipo de regime militar em que foram confinados aqueles soldados, pelo fato de haver uma situação, pensada para um caso específico, um objetivo compartilhado por todos, isto é, o de estudar uma língua para poder sobreviver num país estrangeiro.

Mesmo que o sistema educacional recriasse aquelas condições vividas pelos soldados, seria impossível exigir dos educandos a mesma prontidão, visto que o objetivo dos sujeitos são tão diversos. De qualquer forma, essa metodologia foi aplicada em algumas escolas e verificado que os estudantes entendiam mais do que falavam, pois a competência oral ativa não havia sido alcançada. Segundo a comissão, que havia avaliado os resultados desse programa, o não sucesso dessa metodologia nas escolas deveu-se ao fato de não ser exigido mais esforço dos estudantes.

Ainda hoje, os métodos utilizados naquela época são conhecidos pelos professores de línguas, como por exemplo a repetição sistemática de diálogos e a divisão da classe em grupos, sendo que um estudante faz pergunta ao outro e, enquanto isso, o docente circula pela sala de aula corrigindo os erros. Os estudantes trocam de lugares a fim de conversarem com outros colegas de classe e o docente escreve na lousa um vocabulário de apoio para auxiliar nos diálogos ou ensinar novas palavras que surgem durante o diálogo, trabalhando tanto com as estruturas já aprendidas quanto com as novas estruturas gramaticais e sintáticas. Essa técnica de ensino era inovadora para a sociedade da época, pois era possível falar de 
língua estrangeira como meio de comunicação, indo além das discussões, puramente técnicas, que até então eram ensinadas por meio da gramática (Grammar Translation Method).

Com o tempo, foram agregados a essa metodologia os gravadores, que eram utilizados para as aulas de pronúncia, sobretudo no estudo da entoação e do ritmo da L2 e que consistiam, basicamente, na repetição do que era ouvido pelos educandos. Além disso, havia também apresentações de pequenas esquetes teatrais (role play) em que os estudantes eram colocados em situações reais com as quais poderiam deparar-se na guerra, simulando, assim, uma realidade que eles deveriam improvisar com a ajuda das palavras-chave ensinadas pelos diretores do curso.

Ainda, no relatório da Commission of Trends in Education of the Modern Language Association of America, Passel (1983) comenta que a leitura de jornais e livros era estimulada pelo auxílio de um dicionário. Ao final do curso de 36 semanas, os soldados deveriam ter lido 72 livros, uma média de 2 livros por semana, além do jornal que era lido diariamente. No início do curso, os textos dados pelos diretores eram simples, mas traduzidos pelos soldados a muito custo; entretanto, ao final do curso eles acabavam chegando a discussões pormenorizadas do que era lido.

Os textos lidos pelos soldados eram sempre originais e selecionados pelo diretor, pois este considerava os conteúdos aprendidos e o grau de dificuldade que os soldados encontrariam naqueles textos. Esses textos versavam sobre geografia, história, economia e cultura do país da língua estudada. A L2 (língua estrangeira) era, constantemente, traduzida para a L1 (a língua inglesa) no decorrer do curso pelo fato de temerem distorções na compreensão, evitando assim, interpretações errôneas da L2. Os diretores do curso não se preocupavam tanto com a expressão escrita, pois a prioridade era a comunicação oral. 
As tarefas realizadas em casa eram discutidas e tanto os diretores lingüistas experientes - quanto os repetidores pediam para os soldados estudarem em casa e prepararem alguns exercícios que os auxiliariam na sala de aula, conseqüentemente, na produção oral. Esses lingüistas observaram que a utilização de um vocabulário livre, ensinado aos soldados, não era adequada às exigências lingüísticas do cotidiano e, obviamente, eram diferentes das situações aprendidas em sala de aula. Para isso, organizaram listas de vocábulos que, provavelmente, poderiam ser utilizadas nas ocupações daqueles soldados. Contudo, observaram, também, que aprender listas de palavras não era produtivo, uma vez que deveriam saber utilizar aquelas palavras em contextos específicos e não isoladas, como até então faziam.

Como foi mencionado anteriormente, em 1943-44 não havia grandes recursos tecnológicos como temos hoje. Para o aperfeiçoamento da percepção auditiva, os estudantes costumavam escutar o rádio na língua que estudavam, além de utilizarem toca-discos e, mais tarde, rolos de fitas que auxiliariam no treinamento auditivo do estudante. Inicialmente, esses recursos eram falhos, pois não havia um mercado especializado na gravação de ensino de línguas. Posteriormente, começaram a surgir os primeiros discos com pausas para repetições e respostas que, obviamente, não seriam necessários na sala de aula, pois o professor nativo já fazia esse papel. Assim, esses discos eram utilizados nas horas livres como exercícios auditivos suplementares. Entretanto, com o advento do tocafitas, usado nas gravações de programas radiofônicos da época, os estudantes acabaram se beneficiando, uma vez que poderiam escutar textos e observar o seu progresso na compreensão auditiva; mais tarde, as fitas magnéticas começaram a adotar o mesmo procedimento dos discos que continham intervalos para o estudante repetir ou responder. 
Os filmes da L2 não eram utilizados na sala de aula, porém estudados nas horas livres, por serem um material fácil de manejar; assim, os soldados poderiam interromper ou rebobinar esses filmes e assisti-los quantas vezes desejassem. Apenas alguns lingüistas pediam aos seus estudantes que resumissem a história vista, propondo alguns exercícios de compreensão. Posteriormente, os estudantes relatavam, discutiam ou resumiam algumas das cenas vistas no filme, as quais haviam sido selecionadas pelos lingüistas. Os estudantes também assistiam a palestras na língua estudada, propiciando um contato real com diferentes sotaques. Além disso, eles eram convidados para almoçar ou jantar, utilizando a L2 de forma espontânea e em contextos reais.

Todas as condições criadas para o curso foram efetivamente proveitosas e levaram, em pouco tempo, esse curso ao sucesso. Com base nos relatórios levantados pelo Comission of Trends in Education of Modern Language Association of América, esse programa militar de aprendizagem de língua estrangeira serviu de base para os estudos de uma nova pedagogia de ensino que ainda estão em vigor no mercado. De qualquer forma, independente da metodologia ou abordagem que o educador escolha, ele deverá observar não só a época em que o indivíduo está inserido, mas também as necessidades de cada educando nesse processo de aprendizagem.

Vejamos as metodologias e abordagens que foram surgindo ao longo dos anos ${ }^{19}$ :

> Grammar Translation Method ou método tradicional (método mais antigo que data do século XVIII e que vigorou até início do século $X X)$;

> Direct Method (após a década de 40);

19 As metodologias e abordagens foram apenas mencionadas a título de esclarecimento; não fazem parte do corpus da pesquisa. 
> Audio-lingualism ou método do exército (1940-1950);

> Cognitive Code Learning (no final da década de 50 e no começo dos 60 anos);

> Community Language Learning (1972-1976)

> Comunicative Approach (1979);

> Natural Approach (1981-82);

> Lexical Approach (1993);

> Task-based learning (1996);

> Cuisenaire Rods (1952);

> Silent Way (1972);

> Suggestopedia (1979);

> Total Physical Response (1982);

> Presentation, Practice \& Production Method (1986);

> Computer-assisted Language Learning (1998).

Os métodos são criados, em princípio, para atender as necessidades de uma época em questão e algumas escolas de idiomas ou docentes continuam insistindo em livros ou métodos já ultrapassados. Não queremos dizer, contudo, que esses métodos não tenham sido eficazes, mas eles devem ser sempre repensados e reelaborados para a época, em questão e para o educando que não é o mesmo da $2^{\circ}$ guerra mundial; o histórico daqueles discentes era outro, sua relação com a língua também e, com relação aos meios tecnológicos ou métodos e técnicas de que eles dispunham, era pouco em vista do que temos hoje tanto em material didático quanto em tecnologia para o ensino de língua inglesa. Todavia, há uma grande variedade de abordagens metodológicas distintas no mercado 
de ensino de línguas, algumas vezes são até sui generis como, por exemplo, o método sugestopédico (informação verbal) ${ }^{20}$.

Ainda hoje, há escolas que privilegiam apenas a gramática que sabemos ser necessária para se estruturar a L2, mostrando as leis que regem a língua, nos níveis morfológico e sintático. Entretanto, trabalhar visando só a gramática torna o ensino da língua mais rígido, hermético e, até mesmo tedioso, comprometendo as outras habilidades lingüísticas da L2 (speaking e listening) que acabam não sendo exercitadas, pois não são requisitadas nesse tipo de método.

Geralmente, os discentes desse método possuem uma boa compreensão textual e escrevem bem, tendo uma ótima performance em testes de proficiência, entretanto, não conseguem expressar-se verbalmente ou não possuem uma acuidade auditiva satisfatória. Expressar-se na língua inglesa não significa debruçarmos sobre os livros de gramática durante horas, mas tomarmos consciência dessas regras, estudando-as em contextos diversos para compreender a maneira pela qual a língua articula tais regras, o que seria suficiente para o educando começar a estruturar a língua e, assim, entender e discutir sobre suas próprias dificuldades.

Nesse sentido, acreditamos que essa forma de lidar com a L2 permite uma flexibilidade maior e participação mais ativa do educando em relação

\footnotetext{
20 Sugestopedia: Na década de 60, o médico e educador búlgaro Georgi Lozanov descobriu que existe um "estado mental" propício para a aprendizagem e que qualquer indivíduo, conduzido a este estado mental, aprende mais e melhor num espaço de tempo bem menor. Esse estado mental foi denominado"estado de vigília relaxada" e é obtido quando o nosso cérebro passa a operar na faixa de 8 a 12 ciclos por segundo, ou seja, quando o cérebro entra em "alfa". Para abaixar a freqüência mental dos seus discentes, Lozanov experimentou começar as aulas com sessões de relaxamento bioenergético associado à música barroca. Diante disso, seus discentes, livres de tensão e do estresse, começaram a refletir uma melhora significativa na percepção, processamento, memorização e recuperação das informações aprendidas, sobretudo, na aprendizagem de língua estrangeira.
} 
ao seu objeto de estudo, além de tornar a aula mais agradável e dinâmica, pois há uma participação ativa do sujeito na construção de sentido de uma outra língua, que Ihe faculta (re)pensar, errar e/ou acertar. A gramática, certamente, é necessária, mas precisa ser ensinada de modo prazeroso. Por essa razão, os jogos ajudam muito nesse processo de aquisição de regras, possibilitando ao educando construir um entendimento do universo lingüístico estudado. Uma prática mais interativa com o objeto de estudo traz o sujeito-aluno mais próximo da conceptualização da $L 2$.

As escolas de idiomas, sobretudo as que são franquias, privilegiam um determinado método e este, por sua vez, segue sempre um mesmo formato pedagógico, o qual não permite ao docente a confecção de outros materiais ou técnicas e métodos, pois um treinamento prévio determina a maneira de o docente ministrar suas aulas e o material a ser utilizado. Podemos aprender com esses métodos, em especial no início de carreira; no entanto, acreditamos que o diferencial esteja numa forma de trabalho mais direcionada ao sujeito-aluno, necessidades imediatas e interesses particulares, com métodos e técnicas criativos que envolvam as novas tecnologias, pensando, primeiramente, na maneira pela qual ele aprende e como poderemos utilizar o que aquele indivíduo traz, a fim de propiciar uma otimização no ensino da língua.

Diante disso, depois de levantarmos alguns dados sobre o sujeitoaluno, devemos pensar em abordagens diferenciadas de aprendizagem que vá ao encontro das necessidades dele. Abordagens essas que privilegiem e envolvam um lado mais comunicativo por serem eficazes e ativas se considerarmos que a maioria dos educandos procura comunicarse em inglês, sobretudo aprender o discurso oral. Um adulto que já tenha tido experiências anteriores não tão agradáveis no aprendizado da L2, procura algo diferente e que lhe tire o mal-estar que carrega consigo da língua inglesa. Por conseguinte, aulas que sejam mais atrativas, bem 
humoradas e pragmáticas, trazendo o sujeito-aluno mais próximo da aprendizagem de uma língua de forma proveitosa.

Nenhum método é infalível, a questão é podermos chegar a uma situação ideal ou desejável de construção do sentido de uma língua e, para tanto, ambos os sujeitos envolvidos nessa relação precisam cumprir seus papéis: o educador, procurando um caminho viável para o educando aprender, e este, procurando participar mais ativamente de seu próprio processo. O que se percebe, com relação aos métodos adotados pelos docentes de língua inglesa, é ainda reflexo de técnicas ultrapassadas em alguns casos e que deveriam, pelo menos, serem adequadas ao educando e ao momento. Nesse sentido, teríamos um educador desperto ao novo, mais criativo e participativo na construção de um /fazerl o outro aprender, acompanhando, também, a demanda de mercado, com relação às necessidades do educando nessa era da globalização.

Assim sendo, as escolas continuam trabalhando com as mesmas metodologias de muitos anos atrás, em que o mundo era diferente do que é hoje, acrescentaram apenas o computador aos seus laboratórios de línguas. Os livros foram atualizados, mas os métodos e técnicas continuam os mesmos. Mesmo tendo o computador como um elemento a mais na aprendizagem do educando, ele ainda é usado de forma limitada; os laboratórios de línguas de algumas escolas utilizam o computador para fazer exercícios ou para escutar os diálogos, isto é, passou de um livro para o computador com recursos de multimídia. O uso do meio eletrônico é uma forma de implementarmos as aulas e pensarmos em uma maneira de fazer com que essa tecnologia seja bem aproveitada por meio dos sites de chats, pesquisas, artigos, livros, entre outros assuntos.

As pesquisas sobre a utilização da tecnologia da informação para fins didáticos vêm sendo desenvolvidas desde 1980 e, se soubermos como utilizar os recursos dessa tecnologia ou adaptarmos algumas práticas 
pedagógicas para atender necessidades específicas, proporcionaremos ao educando um input mais significativo. Precisamos, então, olhar o mundo a nossa volta e o que ele nos traz com relação à tecnologia, adaptando nossos métodos e agregando ou substituindo crenças que, para o homem de hoje, não fazem mais sentido, precisamos nos desapegar do passado. O educando de uma determinada época é diferente do educando de agora, por isso o educador precisa estar em uma constante atualização de tecnologias e métodos para agregar, adaptar ou banir conhecimentos ou métodos já ultrapassados.

As novas tecnologias trazem mudanças, o que implica novas abordagens teóricas e metodológicas. Apesar da emergência instaurada pela sociedade quanto ao saber da língua inglesa, o indivíduo está inserido nesse mundo e também traz consigo todo um contexto sócio-históricocultural, que interfere, diretamente, no seu processo de aprendizagem. Essa é a razão pela qual precisamos fazer uma entrevista com o novo educando no primeiro dia de aula, pois seremos capazes de entender com quem lidamos e o que ele espera de sua aprendizagem da $L 2$, até mesmo suas frustrações na tentativa de aprendê-la. Tudo o que pudermos obter desse sujeito-aluno tanto no âmbito pessoal quanto lingüístico, servirá para entendermos o modo como elabora e lida com a L2 e com aqueles problemas lingüísticos que não foram trabalhados ou percebidos no passado, levando-nos a elaborar um curso mais direcionado às necessidades emergentes e a maneira pela qual ele poderia lidar com seu objeto de valor.

Outro ponto a ser pensado diz respeito aos parâmetros metodológicos e didáticos que, por vezes, acabamos seguindo durante os cursos ou treinamentos para docentes, dentro uma visão européia pré-estabelecida como sendo o padrão adequado ou ideal no ensino de língua inglesa. Entretanto, quando falamos em didática, temos em mente a maneira de 
ensinar, o que significa transmitir e gerar um saber no outro. Portanto, devemos pensar quem é o outro a quem ensinamos, quais são as suas necessidades, de que meios dispomos para trabalhar a transmissão de um saber levando esse outro a construir um sentido significativo na L2 e qual é o objetivo desse outro com relação à L2. Assim, pensar em métodos e técnicas no ensino da L2, é pensar em trabalhar, sobretudo com um outro cindido, em falta, que traz um histórico de sua relação com o mundo, consigo mesmo e com a aprendizagem da língua em questão. Temos um sujeito que precisa atribuir um significado real ao que está aprendendo, desconstruindo os simulacros anteriores relativos à língua e/ou ao papel do docente e reconstruindo outros simulacros e ressemantizando o papel do docente e do próprio idioma numa relação de ensino-aprendizagem.

O universo referencial de um grupo de lingüistas impõe um modo de ensinar, por meio de livros e treinamentos aos docentes, e estes aprendem modelos que serão aplicados para toda e qualquer cultura. Entretanto, esquecem de alguns pormenores: o universo referencial varia de cultura para cultura, dentro da mesma cultura, da mesma sociedade e/ou comunidade e até mesmo de indivíduo para indivíduo e no próprio indivíduo, portanto as abordagens metodológicas deveriam ter tratamentos diferenciados. O ato criativo do educador na elaboração de uma aula parece não ser mais necessário, já que livros didáticos esquematizam uma aula inteira ou os cursos e treinamentos estabelecem uma maneira de ensinar. O educador parece não ter mais uma voz ativa nem o uso de sua criatividade é requerido, pois é mero transmissor de conteúdos e de métodos de livros didáticos.

Os métodos mais dinâmicos, interativos com uma abordagem mais comunicativa são mais eficazes, independente das características do educando. As situações de aprendizagem que colocam esse educando em uma situação mais ativa, durante a aula, acabam por desencadear um 
processo natural de envolvimento cada vez mais amplo com a língua inglesa, além da compreensão da mesma. Assim, a mecanização no modo de ensinar e a utilização do mesmo plano de aula, para qualquer grupo ou indivíduo, não são uma prática educativa aconselhável, uma vez que trabalhamos com as idiossincrasias de um sujeito, dessa forma o que funciona para um necessariamente não servirá ao outro sujeito-aluno.

O educando precisa estar apto para poder entender a L2 em situações distintas, daí a necessidade de variação de temas a serem discutidos, propiciando uma ampliação do campo lexical desse sujeitoaluno, em contextos distintos de um mesmo vocábulo, fazendo-o ser mais atento a essa questão do léxico. Quando lidamos com o léxico de uma língua, precisamos ensinar o sujeito-aluno a pensar sempre em situações contextualizadas para podermos fazer com que o outro entenda e construa um sentido. Por essa razão, chamamos a atenção do educando não só para o léxico, mas também para expressões idiomáticas, classes morfológicas, sintáticas e semânticas, determinantes da função e do sentido atribuído à palavra a serem observadas por ele.

O contexto é fundamental para o entendimento da $L 2$, pois o sentido é construído a partir dele; assim sendo, o educando precisa compreender que, mesmo construindo algo gramaticalmente correto, não significa que o sentido pretendido tenha sido viabilizado pelo enunciado criado por ele; por exemplo, a diferença entre os tempos verbais "going to" e "Will" que apesar de serem usados com a idéia de futuro vinculam sentidos diferentes: 
I am going to buy some clothes I think I will buy some clothes tomorrow. tomorrow.

Sentido: eu planejei fazer isso e Sentido: não planejei nada, mas tenho a intenção de comprar roupas. existe uma possibilidade de ir às compras.

Além disso, o Present Continuous também pode ser usado com a idéia de futuro ou como uma ação que esteja sendo realizada no momento da fala do enunciador ou durante o período em que a pessoa esteja ainda fazendo algo, mas não é, necessariamente, o momento da fala:

\begin{tabular}{|c|c|}
\hline I am buying some clothes tomorrow. & (mesma idéia do going to) \\
\hline I am buying some clothes now. & $\begin{array}{l}\text { (ação está sendo realizada no } \\
\text { momento do enunciado) }\end{array}$ \\
\hline I am buying some clothes this week. & $\begin{array}{l}\text { (a ação não está sendo realizada no } \\
\text { momento do enunciado, entretanto } \\
\text { eu estou comprando roupas nesta } \\
\text { semana) }\end{array}$ \\
\hline
\end{tabular}


Portanto, as aplicações desses verbos serão diferentes, dependendo do sentido que queremos construir. Daí a necessidade de podermos ilustrar essas situações, colocando esses verbos em contextos específicos, para que o uso desses tempos verbais faça sentido ao educando, sobretudo, quando uma determinada situação gramatical ou lexical não fizer parte do sistema lingüístico do educando, pois são línguas diferentes e modos de interpretar e recortar o mundo, também.

Diante da mesma idéia e/ou conceito partilhados tanto na L1 quanto na L2, a explicação de uma situação qualquer, em outro código lingüístico, pode ser mais acessível para o educando, ou seja, a inteligibilidade do sistema lingüístico da L2 será captada mais facilmente. Apesar disso, o sujeito-aluno precisa compreender, desde o início de seu curso, que a tradução de um sistema lingüístico a outro é uma transposição de sentido que tanto poderá perder como ganhar, mas geralmente não cobre todo o sentido que traz uma palavra estrangeira comparada à língua materna ou vice-versa. No dizer de Barbosa (1997, p. 32) "....] na tradução de uma língua para outra, nunca há sinônimos mas, simplesmente, maior ou menor grau de equivalências na 'aplicação' de palavras".

Desse modo, quando traduzimos a palavra driver, teríamos no português "motorista", entretanto driver difere de motorist no inglês, mas em português, teríamos a mesma tradução ou, então, expressões como good evening e good night que também são utilizadas em situações distintas, mas no português diríamos apenas "boa noite". Assim, estaríamos exemplificando alguns dos problemas com que o educando se depara e que precisam ser estudados com ele, levando-o a uma compreensão de sentido, do campo semântico-lexical que cobre aquela palavra em contextos dispares ${ }^{21}$.

21 Trataremos dessas questões do campo lexical no capítulo III, item 3.6 
As palavras que nascem neutras ou em estado de dicionário, ao se contextualizarem, ganham outra dimensão, exprimem valores, conceitos, ideologias, por meio dos diferentes discursos. O educando mais consciente dessas situações lingüísticas tem um olhar mais treinado e uma atitude diferente para com a língua estudada. Não é raro vermos a forma errada de utilização do dicionário bilíngüe e, geralmente, alguns docentes só introduzem o uso do dicionário monolíngüe em etapas mais adiantadas de aprendizagem da língua inglesa.

Todavia, o uso do dicionário monolíngüe deveria ser uma prática estabelecida desde o início para que o educando pudesse ter maior rigor na compreensão de sentido de um vocábulo na $L 2$, podendo, assim, desde cedo compor um sentido, construindo todo um universo semiológico (relação com elementos extralingüísticos) e semêmico (relação com elementos intralingüísticos) ${ }^{22}$ daquele lexema, pois a tradução não é importante, o que importa é o sentido que uma expressão ou palavra vincula num determinado enunciado, que está inserido num contexto específico. Para que isso ocorra, o educador precisa ensinar ao seu educando como trabalhar com os dicionários. Por essa razão, procuramos contextos diversos de um mesmo vocábulo e podemos, portanto, exemplificar ao educando o que o autor do texto quer construir com relação ao sentido, criando possibilidades para que o sujeito-aluno amplie o seu campo lexical e semântico do universo lingüístico estudado.

Independente de estarmos preparando o sujeito-aluno para o mercado de trabalho ou para uma situação mais informal do dia-a-dia, a base lingüística ainda será a mesma. Constrói-se um saber pautado no sistema, na norma e na fala daquela cultura. Partimos desse sistema para construir

\footnotetext{
$22 \quad$ Universo Semiológico e Universo Semêmico: Segundo Pais (1997, p.26), esses dois universos constituem o universo semântico de um código lingüístico e existe entre eles uma interação, um inter-relacionamento contínuo.
} 
uma rede de relações que se estabelece entre os elementos de um universo lingüístico, pois no dizer de Pais (1977, p. 30),

(...) o código lingüístico revê, a cada passo, essas relações, altera-as, ainda que em muito pequena proporção, provocando conseqüentemente deslocamentos e modificações, a longo prazo, profundas nas redes semiológica, semêmica e léxica.

Convém ressaltar a importância de mostrarmos, ao educando, a construção dessa língua em contextos díspares. Inicialmente, com textos mais simples, relativos ao cotidiano e assuntos relacionados ao saber do educando ou interesses pessoais para que possamos começar a expandir para textos mais complexos, os autentic materials, além dos aspectos de ordem cultural, a saber, aspectos tanto da língua com relação aos costumes e valores dos nativos quanto de um capital cultural do sujeito ${ }^{23} \mathrm{e}$ dos jornais e artigos. Com o tempo, agregamos vocábulos de áreas específicas de negócios, em particular na área do educando, que são assuntos mais densos para serem discutidos. Para tanto, o educando necessita de uma base lingüística mais estável, previamente, antes de trabalharmos numa área mais específica.

O mercado de trabalho impulsiona o indivíduo a procurar um curso de língua inglesa, assim, ele busca uma possibilidade de estudar a L2 de maneira diferente do passado. Esse indivíduo ainda acredita ser possível chegar a uma sanção positiva no desenvolvimento de sua aprendizagem. Contudo, o fato de esse sujeito-aluno ter saído e entrado de escolas de idiomas acabou ocasionando aquele mal-estar aludido por ele na

\footnotetext{
23 Segundo Bourdieu, o capital cultural existe sob três formas: 1- num estado de incorporação, sob a forma de disposição do organismo, o qual demanda tempo, pois exige uma incorporação e pressupõe um trabalho de inculcação e assimilação que deve ser investido pessoalmente pelo receptor; 2-num estado objetivado, assim sendo, está sob a forma de bens culturais por meio de livros, quadros, instrumentos, etc. e 3- num estado institucionalizado que é consolidado por meio de títulos e certificados escolares (certidão de competência). (BOURDIEU; 1998: 9-10)
} 
entrevista, levando-nos a pensar no motivo pelo qual o educando não consegue se expressar em inglês ou entender o que está sendo explicado, mesmo tendo estudado em diferentes escolas, por um período de tempo considerável.

É notória, na contemporaneidade, uma exigência de mercado maior do que no passado, com a crescente demanda de cursos de MBA (Master in Business Administration) ${ }^{24}$ e de profissionais capacitados a comunicaremse em língua inglesa, dentro do mercado brasileiro. Para que o indivíduo faça parte de um mercado de trabalho diferenciado, ele necessita de qualificações como a MBA e/ou inglês fluente. Esse último é uma medida classificatória para entrar em empresas brasileiras ou multinacionais, mesmo que, posteriormente, esse indivíduo não venha a utilizar o idioma em seu trabalho. As companhias contratam algumas escolas para avaliarem o nível lingüístico de seus futuros profissionais. Os testes de proficiência escrita e falada são um meio de seleção, o que significa o ingresso num nicho do mercado de trabalho com melhor remuneração.

Porém, esse profissional precisará estar mais qualificado, não só com experiência na área pretendida, mas também com conhecimento da língua inglesa, podendo, assim, tratar de negócios e, conseqüentemente, será melhor para a companhia ter um profissional mais capacitado e preparado para esse mercado globalizado. Por isso, muitas companhias brasileiras ou estrangeiras vêm investindo em seus funcionários, facultando um curso de língua inglesa com a finalidade de ampliar seus negócios no mercado internacional, tendo profissionais capacitados para tratar de negócios em inglês, daí a nova tendência do mercado em "Business English", levando as companhias a procurarem escolas de idiomas que proponham esse tipo de abordagem.

24 MBA: Título de especialização em gestão de negócios em áreas diversas como finanças, marketing, logística, recursos humanos, agronegócio, entre outros. Esse título capacita o profissional a atuar como um executivo em seu segmento. 
Diante dessa situação, o mercado de ensino de língua inglesa vem organizando livros didáticos mais voltados aos negócios e estão sendo vendidos como programas de Business English, conforme comentado. Nesse contexto, o educando precisará expressar-se de maneira correta em situações de negócios, mas a base do que será aprendido terá o mesmo conteúdo lingüístico dos cursos regulares de língua inglesa, chamados de General English.

A diferença entre o Business English e o General English está na abordagem de assuntos e vocábulos que cobrem áreas diversas do mundo dos negócios e que são apresentados a cada unidade do livro, além de técnicas para negociações. Acreditamos que antes de o sujeito-aluno iniciar um conhecimento lingüístico específico, no caso do curso de inglês para negócios, por exemplo, ele deve ter uma base gramatical, sintática, fonológica, semântica e lexical apurada para que depois possa agregar vocábulos ou usar situações de linguagem formal, num discurso oral ou escrito, em situações de negócios.

Infelizmente, essa situação não é viável para um mercado que se encontra saturado pelo número de escolas de inglês que almejam garantir uma participação lucrativa no mercado de ensino de línguas, vendendo, assim, um diferencial de mercado. A fim de conseguirem mais discentes em suas escolas, falam em Business English como se fosse rápido ou melhor para o sujeito-adulto que visa uma colocação no mercado; frases como "Aprenda inglês em seis semanas" ou "Esteja qualificado para o mercado de trabalho, aprendendo inglês para negociações" são comuns nas mídias escritas, televisivas ou eletrônicas. Esses apelos, que manipulam o indivíduo pela sedução ou pela provocação, geram um efeito de sentido nesse sujeito, o qual vai em busca de seu objeto (L2) e de um valor (saber) que o capacitará para o mercado de trabalho ou para melhor colocação na empresa. 
O sujeito que necessita de uma colocação no mercado ou assegurar seu cargo, precisa da língua inglesa e encontra-se sem saída, tendo de enfrentar suas angústias, receios e frustrações relacionados à sua aprendizagem. Muitos desses sujeitos não freqüentam as aulas de inglês por desejarem, mas por uma questão de necessidade emergente no mercado ou como condição para continuarem na empresa. Quando temos um sujeito-aluno, já um tanto desesperançado e que não veio por vontade própria procurar o curso, precisamos entender, inicialmente, o que ocorre com ele, ou seja, o que está por trás das entradas e saídas de cursos de inglês e de onde vem esse medo ou receio, que foi alimentado com o passar do tempo, levando-o a declarar-se incompetente para aprender a língua inglesa.

Diante de tanta pressão do Grande Outro (mercado de trabalho e o chefe), esse sujeito-aluno quer algo diferente, ou seja, um método mais dinâmico que desenvolva suas habilidades lingüísticas num curto tempo de aprendizagem. No entanto, trabalhamos com seres humanos que são singulares e que trazem consigo toda sorte de idiossincrasias, sendo assim, tipos de inteligências diferentes ${ }^{25}$ e que deveriam ser consideradas na elaboração de um planejamento do curso (course design) para as necessidades daquele indivíduo, respeitando suas limitações psicológicas e cognitivas, pensando, também, em sua vivência e bagagem cultural. Trabalhar na diversidade de materiais pedagógicos ainda é a melhor maneira de conseguirmos resultados mais rápidos, em um espaço de tempo menor, mas isso dependerá da disponibilidade do educando em lquerer-aprenderl, quanto mais engajado e envolvido em seu próprio processo, mais rápidos serão os resultados. 
Se conseguirmos trabalhar não só com aquelas inteligências, que são naturais para esse ou aquele sujeito-aluno, mas também com outras que o educando ainda não teve a chance de trabalhar, acabaremos por desenvolver outras habilidades no indivíduo, colaborando para uma amplificação de seus sentidos, até então adormecidos e levaremo-no a um melhor desempenho em sua aprendizagem, corroborando, assim, com o que Landowski diz a respeito de aprendermos sobre o mundo por meio dos sentidos.

De qualquer forma, todo o material escolhido pelo educador deve ter o firme propósito de desenvolver uma competência lingüística no educando, pensando sempre nas necessidades reais dele e dos problemas que ocorrem durante o processo de aquisição. Diante disso, pareceu-nos mais produtivo trabalhar com os problemas lingüísticos, assim que eles se apresentassem ou fossem constantes no momento da produção escrita ou oral, para tanto, trabalhamos apenas com a gramática a partir dos textos que são estudados e dos problemas no discurso oral e escrito.

Com relação aos livros de gramática, notamos que esses apresentam exercícios com sentenças que não estão contextualizadas, o que prejudica o entendimento do educando, cabendo ao educador mostrar as diferenças de sentido. Se o docente trabalhar apenas com frases, compartimentando o sentido, acabará impossibilitando ou retardando a ampliação de sentido de uma palavra e, conseqüentemente, a inteligibilidade da língua.

A despeito dos registros orais e escritos citados acima, esses são materiais que nos auxiliam a elaborar um plano de aula de acordo com os problemas encontrados e, ao mesmo tempo, servem para demonstrar as questões de ordem lexical, sintática, morfológica, semântica ou fonológica para o educando, já que ele mesmo constrói o texto; dessa forma, podemos trabalhar com seus próprios discursos e discutir sobre eles. Além 
disso, o educador precisará sempre dar um feedback ao educando tanto dos exercícios solicitados como tarefa quanto dos exercícios realizados durante a aula. Mas, esse educando deve, primeiramente, tentar corrigir suas lacunas, bem como as falhas assinaladas pelo educador nas tarefas e, assim, encontrar uma solução perante as suas dificuldades. Se o educando for incapaz de identificar o seu erro, perguntas serão feitas acerca da construção frasal dentro de um texto para que ele tire suas próprias conclusões e chegue à resposta correta de modo a levar o educando a despertar uma atenção aos seus discursos e domínio na construção de seus enunciados.

Segundo o que levantamos nas entrevistas com os educandos, uma grande parte dos docentes não corrigia seus discursos orais e escritos e quando essa avaliação ocorria, eles acabavam utilizando uma boa parte da aula, tempo esse que poderia ser usado de maneira mais produtiva, como por exemplo, pedir para o educando que explicasse os erros na frase. Nas aulas em grupo, o educador poderia fazer uma lista de erros dos educandos e transformar em um exercício ou em um jogo de modo que a classe pudesse participar ativamente.

Essa pesquisa levou-nos a constatar que se o educando falasse algo errado, ele deveria ser interrompido e corrigido. Se não houver uma intervenção no ato da fala, ele continuará a cometer o mesmo erro, adquirindo, assim, um vício que será muito mais difícil de extinguir-se, pois o "erro" acabará por fossilizar-se (fossilization process). A interrupção, quando ocorre na produção oral discursiva, parece-nos viável, mas algumas vezes precisamos deixar o educando um pouco mais livre em sua produção oral.

As correções da fala dependem muito da maneira que o educando se sente com essas intervenções. Há discentes que acabam não produzindo por medo de errar, o que não é desculpa para não corrigi-los. Entretanto, a 
maneira que o educador coloca a questão da intervenção, explicando a necessidade da correção, é que fará diferença no modo de pensar e agir do educando. Assim sendo, em alguns casos, anotamos e comentamos, posteriormente, dependendo do educando que estamos ensinando e, em particular, do filtro afetivo do mesmo. Após os comentários tanto da expressão escrita quanto da oral, podemos partir para uma prática mais direcionada (task based methodology).

Nesse sentido, gravar o educando enquanto ele fala pode ser uma maneira de lidarmos com essa questão da interrupção ou com aqueles educandos que se fragilizam com a correção simultânea. Além disso, a gravação do discurso oral do educando poderá ser escutada diversas vezes pelo educador e pelo próprio educando. Para o educador, essa gravação será uma maneira de observar as dificuldades ou erros do seu educando e de que forma ele vem articulando seus enunciados na $L 2$, enquanto para o educando será uma maneira de observar seu próprio discurso e perceber onde ele está errando, tendo, assim, a oportunidade de corrigir-se. Com essas gravações, poderemos trabalhar também com a pronúncia e a entoação, não somente os problemas de ordem gramatical e lexical.

Dos materiais gravados e escritos, o educador poderá manter um registro (jornaul) de aproveitamento do educando, podendo analisar com mais propriedade o desenvolvimento dele e planejar outras tarefas com base no que ele demonstra ter maior dificuldade ou que ainda não está muito claro, levantando alguns dados para uma reelaboração posterior do discurso oral (taxionomia dos erros) do educando. Para que possamos avaliar o progresso de nosso educando, mantemos a gravação da primeira aula e, após um período de aprendizagem da L2, mostramos a ele essa gravação, comparando com a situação atual, assim ele poderá mensurar 
seu desenvolvimento no discurso oral, já que muitos educandos só acreditam em seu progresso oral quando escutam a sua fala gravada.

As aulas devem privilegiar mais o discurso oral, possibilitando um diálogo pautado nas dúvidas e necessidades do educando tanto em aulas individuais (one-to-one class) quanto em grupo (group class), assim, permitirá um espaço maior para o sujeito-aluno desenvolver-se oralmente e esclarecer suas dúvidas. Além disso, elas devem ser ministradas na língua inglesa, mas caso o educando tenha algum problema para compreender a explicação, utilizaremos a L1, a fim de evitarmos a perda de informação, a desmotivação ou a frustração por não entender a explanação.

No entanto, o aspecto chamado de TTT (teacher talking time), que ocorre no decorrer do discurso pedagógico do educador, tem um lado positivo e outro negativo; por um lado o educando desenvolverá a habilidade de perceber os sons e decodificá-los, por outro, se o educador não souber dosar o tempo de sua explicação não melhorará o discurso oral do educando, visto que ele precisa aperfeiçoar não só a escuta, mas a fala, também. Portanto, se o tempo de fala do educador for maior que o esperado, a produção oral será menor, por conseqüência, mais tempo para que o educando adquira essa habilidade (prejuízo no discurso oral), por outro lado, a escuta será otimizada. O equilíbrio entre o falar e o escutar, entre educador e educando, ainda é a melhor solução, sobretudo, em uma aula que seja one-to-one. Contudo, nas aulas em grupo, a fala do educador é bem menor, visto que todos os participantes do grupo precisam desenvolver uma competência oral.

Se considerarmos mais o aspecto verbal para a otimização do discurso oral, então a utilização de vídeos didáticos (vídeos que retratam a situação de uma sala de aula), narrativos (aqueles que contam uma história) ou vídeos mistos (vídeos que misturam características de outros tipos), 
durante a aula, mostram-se bem eficazes quando o educador faz uso do material, adequadamente. O vídeo é uma realidade física materializada que torna possível a simultaneidade da fala com a imagem, pois se complementam, transmitindo mais dados ou informações sobre o que é visto, sendo assim, o educando consegue identificar e conceptualizar mais rapidamente o que vem aprendendo, levando-o a uma significação mais plena da palavra ou grupo de palavras em um determinado contexto.

Os vídeos retratam a realidade de uma outra cultura, levam o educando a construir conceitos, valores e ideologias da cultura estudada, pois ele será capaz de entender uma visão de mundo que o vídeo recorta para ele e isso é somado ao que ele vem aprendendo com a língua, facilitando o entendimento e ampliando sua visão de mundo dessa outra cultura. $\mathrm{O}$ uso desse material, dentro de um processo educativo, auxilia $\mathrm{O}$ educando a perceber o que ele tem aprendido nas aulas, ou seja, a relacionar o conteúdo aprendido, visto que é inserido em um contexto maior, no qual o educando poderá entender melhor como e quando poderia utilizar o que vem aprendendo. $O$ aspecto verbal desses vídeos é importante à medida que constroem e organizam as idéias dentro do quadro de uma cultura.

Mesmo que o educando ainda não tenha uma possibilidade real de vivenciar o que vem aprendendo, ele terá, pelo menos, indiretamente, um aspecto simbólico para ancorar os conceitos, as idéias de seu aprendizado, para que, num segundo momento, ele possa vivenciar isso com seu educador por meio das dramatizações de situações que o sujeito-aluno possa se deparar (role play) ou simulações de seu dia-a-dia na empresa (simulation), ou ainda, das aulas externas em ambientes diversos.

Algumas técnicas são utilizadas para que o educando entenda as ações que se passam nos vídeos, mas, dentre elas, existe uma em 
especial que parece ser mais interessante, pois trabalha a atenção de uma outra forma. Primeiramente, o educando apenas vê as imagens e observa as ações dos atores no vídeo sem o som, isso leva o sujeito-aluno a voltar a sua atenção mais para a ação, ao que está acontecendo. Após esse procedimento, é pedido ao educando que explique o que viu.

Assim, possibilitamos ao educando, uma elaboração de seu discurso oral na L2, já que terá de criar ou explicar o que foi assistido por ele. $\mathrm{O}$ educador poderá fazer perguntas ao educando, levando-o a construir uma idéia do que assistiu no vídeo, mas poderá, também, somente escutar o educando, auxiliando-o no vocabulário e nas estruturas frasais. $O$ vídeo é mostrado novamente, mas agora com som, e o educando pode comparar o que ele disse com a fala dos atores. Com isso, queremos despertar no educando uma amplificação do seu olhar, dentro de um contexto mais amplo, em que as imagens o ajudem a compreender o que é expresso na L2.

Normalmente, o educando presta mais atenção às palavras no discurso oral e não olha a cena como um todo; de maneira similar, ele lida com as palavras no texto escrito, pois vê cada uma delas isoladamente, acarretando problemas de entendimento. Se, em princípio, ensinarmos ao nosso educando as estratégias de compreensão tanto num texto escrito quanto num falado, iremos ajudá-lo a criar mecanismos de estratégia textual, que poderão ser utilizados no seu dia-a-dia quando necessário.

Com o tempo, apresentamos outros tipos de vídeo ao educando como, por exemplo, vídeos de reportagem, de documentários, poéticos, dentre outros, até mesmo selecionamos cenas de filmes que o sujeito-aluno conheça ou goste para termos uma motivação a mais para o educando lquerer-entender/ o que ocorre no filme. A narratividade em filmes é bem mais difícil, pois é feita para o nativo ou pessoas que já possuem uma boa 
fluência na L2, o que não impede de começarmos a expor nossos educandos a essas situações reais da língua inglesa, explicando que, com o tempo, eles serão capazes de entender e discriminar os sons e o significado das palavras numa situação, mas isso leva tempo, comprometimento e muito estudo.

Uma outra habilidade a ser desenvolvida é o discurso escrito, que devemos deixá-lo para ser cumprido em um espaço distinto da sala de aula, já que o educando deve despender um pouco mais de tempo para organizar o seu raciocínio, pesquisar ou estudar o vocabulário e a gramática. Na sala de aula, trabalhamos apenas com o discurso oral (aulas práticas com atividades orais), tendo um bom material de apoio, especialmente materiais visuais e audiovisuais para que o sujeito-aluno possa construir seu discurso, partindo de imagens, situações reais ou simuladas, que o ajudam na formação da imagem mental de uma determinada situação, seja do sentido de uma palavra, frase ou expressão idiomática.

Quanto aos exercícios gramaticais, estes estão relacionados aos erros ou dificuldades encontradas pelo educando durante a produção oral na aula e/ou após corrigirmos algumas tarefas do sujeito-aluno. Dessa maneira, poderemos ensinar a gramática de uma forma mais coerente, visto que partimos das dificuldades do educando.

Entretanto, é desejável que o docente dê exercícios mais simples inicialmente, uma vez que esse educando possui um histórico de fracassos com relação à L2 e sente-se inseguro. Com o tempo, poderemos aumentar o grau de dificuldade dos exercícios ou atividades propostas, pois o sujeitoaluno sente-se mais seguro, motivado e pronto para fazer exercícios com maior grau de complexidade, sem o risco de desmotivá-lo novamente ou, até mesmo fazê-lo desistir de estudar. A sensibilidade do educador nesse processo inicial é relevante para que se possa construir um saber pautado 
no desenvolvimento lingüístico do educando. Para tanto, o educador precisa convencer o educando da necessidade de fazer os exercícios propostos, visto que convencer é fazer o outro / $\mathrm{crer} /$ e persuadir é fazer o outro /fazerl, mas o fazer persuasivo do enunciador-educador deve ajustarse ao fazer interpretativo do enunciatário-educando.

No início da aprendizagem, é muito difícil para o educando entender tudo o que o educador explica em inglês, mas algum conhecimento da L2, ele já possui, pressupondo que tenha estudado em outras escolas; porém, ele precisa recordar, trazendo algo que estava passivo, ativo novamente. É uma questão de tempo para que ele se acostume com os comandos na língua inglesa, os quais devem ser explorados nos primeiros dias de aula, mas depende muito da capacidade do docente de fazer o outro entender a sua gestualidade, associada ao discurso verbal, ou seja, ser capaz de transformar algo que é verbal em não verbal, sendo passível de entendimento pelo educando, tornando a aula dinâmica e interessante. Sendo assim, o educador trabalha com a explicação por meio da gestualidade ou demonstra por meio de exemplos claros e/ou materiais paradidáticos, desse modo, o educando ligará a ação à palavra ou a uma situação mais rapidamente.

No entanto, não afastamos a possibilidade do uso da língua materna com o educando após algumas tentativas para fazê-lo compreender o que ensinamos, pois não queremos provocar nenhum mal-estar durante seu processo de aprendizagem. Se utilizarmos exemplos relacionados a contextos específicos, em particular aqueles que estiverem relacionados ao mundo desse sujeito-aluno, sua capacidade de inferir tornar-se-á mais ativa e rápida, trabalhando o processo de semiotização do que está sendo estudado.

Além disso, poderemos explicar algum conteúdo lingüístico por meio dos exemplos retirados da produção escrita ou oral do educando ou de 
exemplos criados pelo educador, que podem ser comparados entre si, e o educando tentará explicar as diferenças percebidas por ele de tais exemplos e, assim, construir um raciocínio mais analítico. Desse modo, ele inicia um processo de discriminação lingüística entre os termos de uma sentença, tornando-se cada vez mais apto e auto-suficiente para perceber suas próprias lacunas.

Se pensarmos no motivo pelo qual um indivíduo aprende mais rápido uma língua no exterior, chegaremos a uma conclusão óbvia, o discurso oral desse indivíduo foi otimizado, pois ele precisou empreender todos os seus esforços para comunicar-se com o outro, visto que foi compelido a encontrar um meio para isso e não haveria possibilidades de ele expressar-se em sua língua materna. Diante disso, o sujeito observa uma determinada ação e infere algo, posteriormente, tenta reproduzir a mesma situação, podendo obter uma resposta positiva ou negativa, dependendo da forma que ele interpretou aquela ação observada anteriormente. Além disso, o fato de um indivíduo estar num país, que fala a língua inglesa, acabará favorecendo situações mais interativas com o idioma, seja por meio dos programas de TV ou das pessoas com quem ele convive e se comunica, sendo assim, estará em um meio propício à aprendizagem, contudo ele precisará /querer-aprenderl e interagir com esse meio que o cerca.

Embora a situação com a qual o nosso estudante brasileiro se depare seja bem diferente daquela, um vez que o educando levará um tempo maior para aprender a L2, no país de sua língua mãe, não devemos esquecer que a aquisição da L2 depende do quanto o educando está disposto a empenhar-se em sua própria aprendizagem. O educador colabora com esse processo de aprendizagem, fazendo que a aula seja bem próxima de situações reais, por meio de materiais autênticos (autentic 
material) ou situações simuladas da $\mathrm{L} 2$, além de outras intervenções metodológicas mais práticas, comunicativas e interativas.

Desenvolveremos, assim, condições para que o educando esteja em constante contato com a língua inglesa, mostrando a ele que, quanto mais ele puder se colocar em situações práticas, melhor será seu desempenho lingüístico. Com o advento da internet, podemos colocar em prática essas situações reais da língua, levando o sujeito-aluno a criar o hábito de comunicar-se em inglês, em especial com nativos da língua inglesa ou conversar com pessoas que utilizam a L2 como meio de comunicação. Assim sendo, ele terá a oportunidade de trabalhar tanto a fala quanto a escrita em sua própria casa ou fazer testes e ler textos on line. Se o educando conseguir estabelecer uma disciplina nos seus estudos, mais rápido ele conseguirá conceptualizar a mesma.

Diante da globalização, temos um instrumental valoroso no ensino de línguas - a internet. O educando pode utilizar-se dela para otimizar sua aprendizagem na L2 por meio de um programa chamado Skype ${ }^{26}$, pois é possível realizar uma comunicação tanto sincrônica como assíncrônica, viabilizando uma comunicação interpessoal. A utilização da tecnologia de multimídias, como CDs-rom são bem interativos e interessantes, já que possibilitam a integração de imagem com o texto escrito e com os sons, auxiliando no desenvolvimento da performance escrita, na compreensão de um texto e na percepção dos sons desse mesmo texto.

Além disso, outras tecnologias são agregadas ao processo de ensinoaprendizagem, como os aparelhos de DVD, que trazem a possibilidade de escolha do áudio e legendas em inglês, e, a TV a cabo, com assuntos diversos, viabilizando o aspecto cultural da língua estudada, também. De

26 Com esse programa é possível falar, escutar, ler e escrever em tempo real (comunicação sincrônica) ou, até mesmo, receber lições em inglês, estudar on line ou receber e-mails de outros colegas em inglês e respondê-los (comunicação assíncrônica). 
qualquer forma, o educador deverá ensinar ao seu educando alguns procedimentos de estudo para que ele saiba lidar com esses materiais citados anteriormente, porém deverá escolher assuntos que estejam relacionados às situações lingüísticas aprendidas, bem como de interesse do educando.

Uma outra habilidade a ser desenvolvida é a leitura, para que possamos testar a compreensão do educando. A leitura de textos deve estar presente, desde o início do curso, para que o sujeito-aluno comece a elaborar melhor o sistema lingüístico, ampliando o vocabulário ou reelaborando os mesmos, construindo e percebendo a gramaticidade da língua. Os textos selecionados pelo educando ou pelo educador podem ser os objetos de discussão de uma aula, sendo que o educando prepararia esse texto antecipadamente para que fosse discutido na aula seguinte.

Assim sendo, priorizam-se, num primeiro momento, textos ou livros curtos de fácil compreensão e que vão aumentando em extensão e complexibilidade, sempre relacionados ao conteúdo lingüístico estudado com o educando anteriormente. A leitura de textos ou livros deve ser constante, diversificada em assuntos, mas que esteja relacionada ao universo do educando (trabalho e interesses) e à cultura da L2. Com o tempo, poderemos expandir essas leituras a outros temas.

Durante a aula, são entregues ao educando textos menores para que possamos propor uma discussão a respeito do assunto tratado nesse texto; dessa forma, estaremos trabalhando tanto a leitura quanto o discurso oral do sujeito-aluno. A habilidade escrita será trabalhada após as leituras, assim, pedimos ao educando para relatar o que ele leu ou discutiu durante a aula. Essa prática é importante, uma vez que irá proporcionar ao sujeitoaluno meios para que ele encontre uma maneira de se expressar no discurso escrito e, para o educador, esse material escrito irá ajudá-lo a 
mapear os problemas de seu educando, fazendo-o elaborar exercícios ou uma aula que tenha como base os problemas que surgiram no texto escrito. Para tanto, o feedback desses exercícios é necessário para o educando desenvolver uma competência escrita.

O discurso oral ou escrito possibilita uma leitura da forma que o educando está decodificando e codificando a L2, ou seja, a maneira pela qual ele está elaborando e reelaborando seus discursos. Afinal, decodificar (fazer o caminho inverso da codificação) é aprender a decompor e reconstruir um sentido nesse processo de aprendizagem, reelaborando e comparando com outros processos já apreendidos anteriormente. Assim, após uma análise desses discursos escritos e falados, o educador elabora maneiras de sanar os problemas encontrados.

A correção desses textos é outro ponto a ser discutido, pois queremos fazer o educando entender as suas falhas ou dificuldades na L2; por esse motivo, apenas circulamos as palavras no texto ou inserimos pequenas anotações no corpo desse texto para que o educando possa ter a oportunidade de pensar sobre essas anotações e corrigi-las. $O$ educando precisa criar o hábito de prestar atenção em si mesmo tanto no discurso oral quanto no escrito, conseqüentemente estaremos trabalhando para a instauração do universo lingüístico da L2 (processo de elaboração e reelaboração do discurso). Mesmo que o educando não consiga corrigir o que está errado, devemos levá-lo a raciocinar, ora fazendo perguntas, ora relacionando a situações dadas em aula ou situações vividas pelo próprio educando.

O ambiente também corrobora para uma prática educativa mais fluida. A possibilidade de propiciar outros locais que estejam além da sala de aula é importante e acabará por motivar o educando. O educando gosta de participar de um Happy Hour num bar ou restaurante, até mesmo participar 
de eventos culturais como exposições, teatro, cinema, dança. Logo após um desses eventos, costumamos ir a um outro lugar e discutir sobre o que foi visto, utilizando a língua inglesa.

Nesses eventos, deixamos o sujeito-aluno expressar-se livremente, sem interrompê-lo com correções e, assim, o educando precisará encontrar uma forma de expor seus pensamentos a outros educandos. Tanto o cinema como o teatro são eventos que auxiliam na aprendizagem, uma vez que podemos assisti-los em inglês, trabalhando tanto a acuidade auditiva quanto o discurso oral posteriormente. $O$ fato de vivermos em um país que não fala a língua inglesa e nem sempre o educando tem oportunidade de utilizá-la, faz o educador criar condições reais para o educando expressarse na L2 e possa sentir, de fato, o que vem aprendendo.

O papel do educador, nesses eventos, é o de observador passivo, ele não está lá com a incumbência de dizer o que é certo ou errado, apenas propicia ao educando um espaço para interagir com os outros educandos e com ele mesmo. Esses encontros podem ser feitos uma vez por mês ou mais, dependendo da disponibilidade das pessoas envolvidas no processo. Contudo, é importante encontrarmos um tempo para que esses encontros ocorram, pois será interessante tanto para o educando quanto para o educador, que poderá observar seus discentes em situações reais de interação com outros educandos. Então, o educador poderá se distanciar um pouco mais de seu papel nesse processo de ensino-aprendizagem para participar e observar a maneira pela qual seus educandos estão desenvolvendo uma comunicação na L2. Sendo assim, será mais fácil para o educador mensurar o grau de compreensão, discernimento, desenvoltura e fluência do educando em uma situação, que não é um contexto de sala de aula, mas um contexto da ordem do real e que o educando terá de lidar, quando for necessário. 


\title{
CAPÍTULO III
}

\section{III - CONSIDERAÇÕES ACERCA DO SABER}

\begin{abstract}
"O conhecimento não deve ser retido na alma como se fosse licor, mas deve ser incitado e gentilmente extraído de seu interior; não para que a mente se encha como uma vasilha, mas para ser inflamada e despertada."
\end{abstract}

Cudworth

Saber, do latim sapere (= ter sabor, gosto), segundo o dicionário Aurélio (1999, p. 1792), "saber" é ter conhecimento, ciência, informação ou notícia de; ter conhecimentos técnicos e especiais relativos a, ou próprio para; ser instruído em; ter capacidade, poder explicar, compreender; erudição, sabedoria, etc. Diante disso, entendemos que o educando precisa "tomar gosto" pelo novo, adquirindo conhecimentos técnicos ou não, ter capacidade e erudição, podendo transmitir algum conhecimento aos outros.

Em uma das palestras do professor Charlot (2003, informação verbal), ${ }^{27}$ ele diz que a relação com o saber parte do sujeito e deste para com o mundo. Essa relação com o saber tem como foco não somente o sujeito-aluno, a quem se destina esse novo saber, o educador também tem uma participação ativa numa relação de ensino-aprendizagem. Para Charlot, educador e educando são sujeitos ativos na educação e continua

27 Informação fornecida por Bernard Charlot que é professor de Ciências da Educação da Universidade de Paris VIII, Saint-Denis. Essa palestra ocorreu na Faculdade de Educação da Universidade de São Paulo em 3 abril de 2003 e discorreu sobre "A relação com o saber". 
dizendo que "[...] o aluno leva para dentro de si o que aprendeu, mas utiliza muito pouco" ${ }^{28}$. Daí a necessidade de uma atividade intelectual mais intensa para que o educando possa realmente aprender, ter conhecimento. O papel do docente é de /fazer-aprenderl, gerando um conhecimento no outro, não somente transmitir um saber. Devemos considerar a aprendizagem do sujeito-aluno, trabalhando com elementos que viabilizem um entendimento do que se ensina, construindo, assim, um sentido para esse educando.

Quem explica deve prestar atenção ao outro, na lógica do outro, vertendo o conhecimento qualitativa e quantitativamente, em um crescente elaborado, que nos remete ao Bolero de Ravel ${ }^{29}$. Esse modo de transmitir um saber fará diferença para o indivíduo, especificamente se o material que for utilizado estiver relacionado ao conteúdo lingüístico a ser desenvolvido e às necessidades imediatas do educando, a fim de imprimir uma significação real do que está sendo aprendido e que irá acompanhá-lo durante seu desenvolvimento cognitivo da L2, ganhando uma outra significação, produzindo, assim, uma ponte ao novo, visto que condições foram criadas para favorecer a aprendizagem desse educando, levando-o a ter vontade de continuar aprendendo. Contudo, isso somente será possível devido à forma de ensino que fará o educando querer saber mais sobre a L2, uma vez que tenha sido seduzido pelo saber.

Grande parte dos discentes brasileiros provém de um sistema de ensino falho, possuindo uma relação com o saber compartimentada. Eles

\footnotetext{
28 Id., 2003

Bolero de Maurice Ravel: o compasso rítmico do bolero repete-se sempre com a mesma configuração melódica até o fim, salvo a dramática substituição do final e antes do acorde conclusivo, sendo que cada instrumento é acrescido ao todo, gentilmente, cada vez mais forte, intenso, num crescente, em uma grande espiral que culminará em uma explosão de todos esses instrumentos tocados nesse todo ao mesmo tempo, culminando numa polifonia bem orquestrada e, dessa forma, o saber poderia ser vertido para dentro de qualquer sujeito-aluno.
} 
carecem de uma relação entre os diversos saberes, além disso, os saberes de ordem cultural não são cultivados desde cedo. Pudemos notar que outros saberes, mesmo os de ordem cultural, fazem diferença no processo de aprendizagem do indivíduo adulto. Quanto maior for o universo lingüístico e cultural do indivíduo, mais fácil será instaurada uma aprendizagem (maior abstração, inferências, dentre outros). A cultura e educação são uma coisa só, não existe uma cisão entre elas. Então, quanto mais saberes o indivíduo puder ter contato, sobretudo os culturais, melhor será a sua capacidade de cognição acerca do que aprende.

Assim sendo, o ser humano precisa de um universo referencial ou antropocultural ${ }^{30}$, presente no mundo que o cerca, para poder simbolizar, ou melhor, operar uma redução das coisas do mundo a modelos que leve o educando a reconhecer as mesmas situações ensinadas anteriormente, pois ele acionou aqueles mesmos modelos mentais que já havia aprendido, podendo, assim, organizar e estruturar pouco a pouco as novas informações da L2, seja ela por meio da ação (da práxis) ou apenas pelos sentidos. A concretude de uma ação que, em princípio, poderia ser da ordem do não real (simulada, por exemplo), torna-se real e passa a ter sentido, significação. Pais (1977, p.25) comenta o seguinte sobre a visão lingüística do mundo que o indivíduo semiotiza:

(...) a forma do universo antropocultural será a substância do universo semiológico, os modelos do primeiro serão os objetos a partir dos quais o segundo elaborará uma visão lingüística. Penetramos, assim, no território da semiótica lingüística. Reencontramos aqui os mesmos esquemas lógicos conceptuais subjacentes. Opera-se a redução dos objetos a modelos e há, simultaneamente, compartimentagem e classificação. Estabelece-se, assim, a estrutura do universo semiológico. Os mesmos princípios de ordem, posição, pertinência a um grupo, definem as

$30 \quad$ Segundo Pais (1977: 23-24), compreende todos os dados da experiência humana. Esse universo referencial ou antropocultural é classificado pelos antropólogos em biofatos (fatos do universo físico e biológico), os sociofatos (fatos da vida social), os mentefatos (fatos da vida psíquica) e os manufatos (objetos fabricados pelo homem). 
relações de dependência, as funções, que opõem os elementos uns aos outros. Classemas, no sentido greimasiano, temporais, espaciais, etc., determinarão a distribuição dos elementos em campos semânticos, ou topoi (classes e subclasses), estabelecendo-se subsistemas e microssistemas.

Aprendemos percebendo como as coisas funcionam, comparando os erros com os acertos e através da percepção reconhecer o mundo. Para que isso ocorra, o educando precisaria ter uma participação mais ativa nesse processo de aquisição da L2. Uma das coisas que corrobora para um melhor entendimento da língua aprendida é por meio do que chamamos de 'elementos correlatos' ou 'significações correlatas', citados anteriormente. Quanto mais precisos e bem elaborados forem esses 'elementos correlatos', mais eficaz será a internalização da L2 e, conseqüentemente, a produção será mais rápida, assim sendo, levaremos o educando a construir uma significação interna que passará a fazer sentido e, aos poucos, ele próprio começará a tecer outras considerações e caminhar por si mesmo.

Tais 'elementos correlatos' ou 'significações correlatas' são signos passíveis de uma observação e uma inferência maior pelo educando que, por meio de comparações, poderá simbolizar e tecer considerações a respeito do que está sendo explicado. Esses elementos são de duas ordens: uma da ordem dos objetos reais no mundo tanto por meio de figuras como situações do cotidiano e o outro tipo parte de suas próprias experiências de aprendizagem, ou seja, de assuntos que os educandos gostem ou tenham competência (experiência na área, em que trabalham ou, então, um hobby, ou talvez seja algo que lhes interessa e saibam bem). O primeiro tipo utiliza-se de flash cards, filmes, ou situações que reconstruam e contextualizem a idéia de uma ação ou palavra. 
O outro tipo de 'elemento correlato' parte das experiências do educando em algo que ele já é competente, mas que poderá vir a ser necessário, quando o educando se mostrar resistente perante alguma atividade proposta pelo educador. Sendo assim, precisaremos provar para o educando o motivo pelo qual seria importante fazer o que lhe é pedido durante o processo de aquisição da língua, demonstrando por meio de algo que ele seja capaz de compreender as etapas de instauração de um processo de aprendizagem, seja ele qual for. Geralmente, a maneira com a qual lidamos com as coisas de que gostamos, nos faz passar por etapas de aprendizagem, nesse sentido, podemos comparar essas etapas ao processo de aprendizagem de um sistema lingüístico.

Tomemos, por exemplo, um sujeito-aluno que não entende a necessidade de fazer exercícios ou não gosta de fazê-los. Pedimos a ele, nesse caso um programador, para falar um pouco de sua profissão e o que seria necessário fazer para viabilizar seu trabalho de programação de dados num computador de uma empresa. Como esse educando trabalha com a tecnologia da informação, primeiramente, ele terá de pensar num plano para fazer o que a empresa Ihe pediu. Um programador trabalha sempre com dados que the são fornecidos pelo cliente e ele precisará saber o que esse cliente deseja habilitar em seu computador para cumprir uma tarefa específica na empresa; dessa forma, deverá colocar dados nesse computador, criando uma rede de informações que seguem as diretrizes pedidas pela empresa e que sustente as necessidades daquele novo sistema a ser implantado.

Após a explicação do educando, comparamos com a L2 para que ele entenda a maneira que um saber irá se estruturar no indivíduo, fazendo-o notar a semelhança com o seu trabalho, pois transpomos uma idéia para uma outra situação, passível de comparação. Comentamos com o educando a importância da aprendizagem da língua, que é muito parecida 
com o que ele faz no sistema operacional dos programas criados para um fim específico, com a diferença que o ser humano possui um software mais sofisticado e acaba por tecer outras considerações por si mesmo após ter alimentado e realimentado o sistema lingüístico com informações pertinentes às que vem aprendendo, da mesma forma alimentamos o computador com informações para responder a determinadas ações.

Temos, então, uma rede de informações que se processam em cadeia, como o nosso cérebro que tece significações e vai construindo o sentido pelo encadeamento de estruturas morfológicas, sintáticas, semânticas, lexicais e fonológicas, com a diferença que o cérebro, depois de um tempo de regulagem do sistema (auto-alimentação e realimentação), passará a pensar, inferir e a tecer outras considerações por si mesmo, após um bom número de informações lingüísticas e de tempo despendido para a aprendizagem da língua.

Diante dessa explicação, o educando não precisa de muito tempo para entender a necessidade da gramática ou de outros exercícios escritos e orais que são um input necessário para que ocorra a conceptualização de um novo registro lingüístico e, assim, ele estará ciente de que a produção oral ou escrita será o resultado do que ele vem apreendendo e, portanto, a maneira pela qual a construção do sentido de uma língua irá se estruturando em nosso cérebro (processo epistêmico do mundo). Em princípio, esse tipo de 'elemento correlato' pode parecer banal, mas para o educando passará a ter outro sentido e ele começará a olhar a L2 de outra forma, sobretudo se a comparação partiu de algo de que ele goste e compreende bem o funcionamento.

Todavia, o sistema lingüístico deve ser sempre realimentado para que possa construir novos sentidos, ampliando cada vez mais o universal lingüístico; dessa forma, a manutenção do sistema lingüístico e as redes de 
significações que vão sendo tecidas, ao longo do tempo, serão amplificadas e possibilitarão uma variedade cada vez maior de interlocução entre campos semânticos distintos, conseqüentemente áreas de conhecimentos distintas. Por essa razão, precisamos expor o nosso educando a situações e temas diferentes, não somente de uma área que ele domine ou tenha interesse.

Os 'elementos correlatos' auxiliam o indivíduo a fazer uma redução dos fatos semiológicos (substância) a modelos por uma relação de equivalência, ou seja, pela relação dos objetos em lato sensu (forma) relacionados ao universo antropocultural do indivíduo e, assim, fazê-lo entender o que queremos explanar. Dessa forma, o indivíduo começará a operar uma rede semiológica, a qual irá sempre reduzir os objetos a modelos que serão compartimentados e classificados simultaneamente às informações recebidas. Com o tempo, essa rede semiológica será ampliada, formando o universo semiológico daquela língua em que os elementos lingüísticos irão se distribuir em campos semânticos (topoi = classes e subclasses), estabelecendo, assim, os subsistemas e microssistemas de um universo lingüístico.

\subsection{Postura do educador na transmissão de um saber: implicações pedagógicas}

Pais (2000, p.113) diz que o discurso pedagógico é voltado para a formação e informação e que se propõe a criar e transmitir conhecimento, gerar uma competência, despertar uma vocação. Para que esses aspectos sejam efetivados, o professor-educador precisa pensar em quais recursos poderão ser usados para cada educando ou grupo de educandos, visto que a maneira de ensinar varia de educando para educando e as necessidades são diversas. Esse educador precisará pensar, também, a maneira que o educando interage com o material selecionado e o processo em si de 
aprendizagem da L2, bem como o próprio educador interage com seu educando. Além disso, o educador deve buscar a ampliação de seus conhecimentos e se manter atualizado com as novas tecnologias, métodos e técnicas.

O discurso pedagógico ajuda a construir uma competência no sujeitoaluno, que é um sujeito do fazer interpretativo. Provido de uma competência semiótica, o educador observa a maneira pela qual seu educando interpreta e tece considerações, assim, será capaz de planejar com maior precisão o que é necessário para o sujeito-aluno. Aquele discurso constrói no educando um /saber-fazerl, gerando nele uma competência, pois o educando poderá ser capaz de /poder-fazer/; nesse caso, poder comunicar-se em inglês desde que trabalhe em seu próprio processo de aprendizagem, isto é, o desempenho do educando durante o processo de aprendizagem dar-lhe-á maior ou menor competência, dependendo da forma pela qual ele irá conduzir seus estudos.

A fala do educador credita a possibilidade de o outro aprender a língua, construindo nele um simulacro de um /poder-fazerl, fazendo-o /crerserl possível, mediante uma manipulação por sedução ou tentação, mostrando-lhe que, por meio de seu desempenho lingüístico, o educando pode conseguir uma sanção positiva ao final do seu percurso, desde que exista uma disponibilidade dele em fazer algo por si mesmo, pois os simulacros são construídos a partir do que acreditamos. O educador não deve se distanciar de seu Ov (educando), pelo contrário, ele aproxima-se e trabalha em uma relação de reciprocidade e flexibilização de um /fazer/, levando-o a ter uma competência lingüística, à medida que o outro tenha um comportamento ativo, uma postura de envolvimento. $\mathrm{O}$ estímulo certo pode desencadear no educando um /fazer-fazer/ por si mesmo.

A despeito de uma relação entre educador e educando (destinação de reciprocidade), Pais (2000, p. 117) diz o seguinte: 
(...) o poder- fazer- saber do sujeito cognitivo só pode realizar-se através de um /poder-saber-fazer/ do sujeito enunciador-enunciatário do discurso, que, manifestandose, conduz à realimentação $e$ à regulagem do metassistema conceptual e dos processos semióticos dele dependentes. O sujeito cognitivo e o sujeito semiótico produzem um saber sobre o mundo e sobre si mesmos e são simultaneamente produzidos num processo, em que são determinantes a racionalidade, a sensibilidade, a intuição, a afetividade e a historicidade.

O diploma qualifica o docente perante a sociedade, ao Grande Outro, em que regras são estabelecidas para que se possa ensinar em estabelecimentos de ensino, entretanto, nem sempre é o que ocorre. Contudo, o que realmente nos outorga a faculdade de ensinar algo a alguém advém de um processo longo e profundo de formação, calcado em uma prática educativa, no conhecimento de seu objeto de estudo, do outro e de si mesmo.

Nas instituições de idiomas nem sempre é possível desenvolver uma prática de ensino que acreditamos ser adequada ao perfil do educando com quem iremos trabalhar, justamente por existirem regras que envolvem um tipo específico de metodologia a ser abordada, que determina a quantidade de horas-aula a serem ministradas por estágio, adotando um livro didático a ser usado e, até mesmo, o material suplementar a ser desenvolvido nas aulas. Essas regras podem impedir um bom desempenho de todos os sujeitos envolvidos nesse processo de ensinoaprendizagem.

Parece-nos que a falta de flexibilidade na maneira de lidar com o educando ou/e a falta de criatividade no trato com o léxico e outros assuntos relativos à aprendizagem de uma língua, não é culpa desse futuro docente, mas do modo como é transmitido o "saber" para esse docente. Geralmente, os docentes seguem a mesma estrutura metodológica e 
pedagógica, dificilmente alguém ousa mudar uma estrutura préestabelecida, ou por falta de ânimo ou por ignorância e, até mesmo, por não ter idéia de como fazer aquele "saber" ser transmitido de forma diferente e criativa. Na verdade, isso não é incentivado durante a formação desse docente. Então, teremos mais um docente que possui apenas uma capacitação perante o mercado. No entanto, não consegue ir além de seu manual de instruções. Infelizmente, são indivíduos treinados para uma forma de lecionar, não são realmente habilitados a educar, salvo algumas exceções. Devemos defender uma prática docente, em que o ensino rigoroso de conteúdos jamais se faça de forma fria, mecânica e mentirosamente neutra, como diz Paulo Freire (2000).

Logo, ou o profissional com mais experiência aceita essas condições e submete-se a elas, mesmo frustrando algumas de suas idéias, ou abandona esse tipo de ideologia. Reconhecemos que existem diferentes abordagens metodológicas, algumas ultrapassadas outras não tão boas, mas que funcionam para determinados indivíduos. Contudo, não as desprezamos, pelo contrário, aprendemos com elas, transformando-as em algo que possa se adequar às necessidades de cada indivíduo, respeitando as diferenças de aprendizagem existentes em cada sujeitoaluno, além de discutirmos as possibilidades de aplicações de alguns métodos e técnicas e suas limitações em alguns casos, visto que a competência e o desempenho variam de indivíduo para indivíduo e no mesmo indivíduo, sendo otimizados pela experiência e a vivência de situações diversas na L2.

Talvez, para um docente principiante seja necessário passar por essas diferentes metodologias que estão no mercado, para depois poder encontrar um meio de desenvolver algo mais significativo com seus educandos, mas que não esteja apenas calcado naquelas linhas metodológicas um tanto quanto ultrapassadas ou que delimitam apenas 
uma forma de ensinar o sujeito. Ensinar faz parte de um processo de individualização e prática, sendo que o percurso a ser feito pelo educador irá depender da maneira pela qual ele trata o seu objeto de estudo, ou seja, o educando e a língua inglesa.

O papel do educador é um retornar contínuo tanto em termos de técnicas e métodos estudados anteriormente quanto aos instrumentais conceituais aprendidos ao longo de sua formação como professoreducador. Retorno esse que deve ser sempre aprofundado, modificado, adaptado ou, até mesmo, abandonar metodologias que não se mostrem mais significativas a uma determinada época ou indivíduo. A academia capacita-nos para o ensino de línguas, formando futuros educadores, mas somente uma prática reflexiva, questionadora e que respeite o sujeitoaluno será capaz de levá-lo a um desempenho diferenciado nesse processo de ensino-aprendizagem. Sendo assim, o educador procura proporcionar ao sujeito epistêmico um desenvolvimento cognitivo, conduzindo-o a um raciocínio lógico e crítico sobre o que lhe é ensinado, criando, assim, possibilidades para o desenvolvimento de estruturas e modelos mentais de um outro universo lingüístico, de maneira a fazer que o sujeito-aluno organize conceitos e idéias num todo coeso e passível de desempenhar, na língua inglesa, uma comunicação efetiva.

Apesar de o docente trazer para a sala de aula algo já programado, ou seja, um conhecimento a ser transmitido por meio de um planejamento, o educador deve ser capaz de desenvolver uma outra aula ou reelaborá-la devido às necessidades que o educando, eventualmente, possa trazer para a sala de aula ou talvez esse educando não esteja bem disposto ou esteja preocupado ou cansado. Para tanto, é preciso que o educador esteja preparado para ministrar uma aula completamente diferente, com jogos, filmes ou músicas, os quais são apreciados pelo educando. Diante desse quadro, o educador tem um 'olhar sensível' sobre as necessidades de seu 
educando, modificando sua aula quando for preciso. O educador escuta seu educando, até mesmo além do que ele fala ou demonstra corporalmente. Assim, parece-nos oportuno comparar o ofício de um psicanalista ao papel de um educador. Segundo Miller (1992)

(...) o ofício próprio do psicanalista é escutar o sujeito além do que diz. Isso é o que se chama interpretação. Consiste em escutar o sujeito não no que ele crê dizer, por exemplo, de racional, mais sim no desejo que flui através do significante que emite.

Nesse contexto, a relação de ensino-aprendizagem que se estabelece entre educando e educador deve ser lida de outra forma nos dias de hoje. Devemos escutar suas necessidades, seus medos, angústias e objetivos para tornar a aprendizagem mais acessível ao educando, independente do mal-estar do passado. Assim, o educador está sempre atento às dificuldades de seu educando, bem como o seu universo sócio-lingüísticohistórico e cultural que influenciam no processo.

Notamos que o "fracasso" na transmissão de um saber lingüístico é devido, em parte, à figura do docente, ou seja, ao modo de ele perceber, relacionar-se ou lidar com o discente, salvo aqueles docentes que possuem um outro olhar nessa relação de ensino-aprendizagem e um comprometimento pela sua profissão. Acreditamos que mesmo aquele que não queira saber pode ser "seduzido" e conduzido a um lquerer-saber/. Partindo dessas considerações é que esse tal "fracasso" na transmissão de um saber ocorre, principalmente com o despreparo de alguns docentes dentro de um circuito de ensino-aprendizagem da constituição e transmissão de um saber. Infelizmente, ainda há docentes que menosprezam o que não é observável, sobremaneira o universo do educando.

Alguns docentes esquecem que adquirir conhecimento advém de várias fontes, não existe só um modo de ensinar e da mesma maneira para 
todos os sujeitos. Se esses indivíduos são singulares, multifacetados, não existe apenas uma forma de se explicar ou de aprender, de olhar para um saber. Ensinar não é tarefa fácil, educar implica não somente transmitir um saber, como também ir além disso. Existe uma imbricação tanto do sujeitoenunciador quanto do sujeito-enunciatário. Pressupõe-se que esse sujeitoenunciador da transmissão do saber estabeleça um liame entre a L2 e o educando, ensinando com mais intensidade e entusiasmo.

Nesse sentido, um educador capacita o educando no desenvolvimento da língua não apenas em sentido estrito, mas ampliando o seu conhecimento sobre ela, fazendo-o pensar na maneira como esse idioma articula-se dentro de um universo lingüístico. $O$ educando vê, no discurso do educador, a possibilidade de aprender a língua inglesa, visto que ele é o sujeito suposto saber, um interlocutor desse saber que o capacitará a uma comunicação por meio da L2. Entretanto, a prática a ser desenvolvida com o educando é uma prática dialógica, sendo que, nessa relação de ensinoaprendizagem, o sujeito-aluno é mais participativo, não apenas em sala de aula, mas fora dela também, buscando respostas para as suas dúvidas e refletindo sobre elas, assim, o educando aproxima-se cada vez mais de seu Ov.

Diante dessas considerações, alguns aspectos devem ser abordados com relação à postura do educador num processo de ensinoaprendizagem, como por exemplo, a ética. Segundo Aurélio (1999, p. 848), ética é um estudo dos juízos de apreciação referentes à conduta humana suscetível de qualificação do ponto de vista do bem e do mal, seja relativamente a determinada sociedade, seja de modo absoluto. 
O filósofo Karl-Otto Ape (informação verbal)| ${ }^{31}$ fala de uma ética de responsabilidade, isto é, uma ética que considera as conseqüências e efeitos colaterais dos atos dos sujeitos agentes. Diante disso, entendemos que o discurso do educador não vincula somente a transmissão de um saber, mas o que acredita, o modo que recorta o mundo e interage com ele e com o outro. $O$ educador é formador de opinião e responsável pelo modo de ensinar algo a alguém, ele é co-responsável pelas conseqüências de suas ações.

Weber (informação verbal) ${ }^{32}$ também discorre sobre dois tipos de ética, a ética de convicção e a ética de responsabilidade. A primeira está no diaa-dia, no que acreditamos, nos valores e nas crenças, no modo de ver, de agir sobre o mundo, e a segunda está relacionada aos atos humanos e essa é importante na formação do educador que deveria ter isso sempre em mente, pois a maneira de lidar com a transmissão de um saber fará diferença na maneira do outro compreender, ver e lidar com seu objeto de estudo, até mesmo gostar ou desgostar do saber que lhe é transmitido, daí a importância da responsabilidade do ato de ensinar o outro.

Ainda, segundo o Aurélio (1999, p. 765), "ensinar" significa transmitir conhecimentos, instruir ou educar e "aprender" significa tomar conhecimento, reter na memória, mediante o estudo, a observação ou a experiência; tornar-se apto ou capaz de alguma coisa, em conseqüência de estudo, observação, experiência,(...). Assim sendo, ensinar e aprender devem estar em relação conjuntiva, dentro de um circuito de ensinoaprendizagem. Um depende do outro para que ocorra uma transformação; tanto um quanto outro precisam de esmero por parte dos sujeitos

31 Anotação das aulas de Epistemologia e Metodologia das Ciências Humanas, ministradas pelo Prof. Dr. José Jeremias de Oliveira Filho na Faculdade de Filosofia da Universidade de São Paulo, em 2003.

32 Anotação das aulas de Epistemologia e Metodologia das Ciências Humanas, ministradas pelo Prof. Dr. José Jeremias de Oliveira Filho na Faculdade de Filosofia da Universidade de São Paulo, em 2003. 
envolvidos nessa relação de ensino-aprendizagem. Falamos aqui de um "ensinar" consciente, implicado com a ética de responsabilidade com o outro, pensando em suas causas, se for usado inadequadamente pelo docente e de um "aprender" ativo, consciente, reflexivo para que o sujeitoaluno se torne apto em conseqüência de seu esmero em /querer- aprender/ o novo.

Existe um outro aspecto a que não é dado o devido valor nessa relação de ensino-aprendizagem: a linguagem não verbal. A gestualidade, as feições e a aparência são textos que também significam, transmitem uma idéia a respeito do indivíduo. A forma de movimentar-se, olhar, gesticular, a vestimenta, até mesmo o perfume que o indivíduo usa são textos, os quais são lidos pelo educando e que acabam por significar algo a ele.

Quando o educador lida com adultos, sobretudo quando leciona inglês nas empresas, precisa estar mais atento ao seu comportamento corporal e, até mesmo, às suas roupas, pois não está em um ambiente informal e, portanto, não caberiam vestimentas inadequadas dentro da empresa. $O$ bom-senso é sempre bem-vindo e adequado às diferentes situações e ambientes em que ensinamos. O ethos de um educador é construído desde o primeiro momento em que o educando estabelece uma comunicação com ele. Um contrato de fidúcia é instaurado nesse quadro apresentado ao novo educando, visto que ele espera de seu educador o que observa, num primeiro contato, não só pelo seu discurso oral, mas pela sua atitude, modo de comportar-se e vestir-se também.

Ao trabalhar com o educando, o educador precisa considerar a maneira de abordar o "erro" durante a produção discursiva do sujeito-aluno. Em se tratando do "erro", é necessário ter um certo tato ao lidar com adultos, considerando que a maioria possui barreiras instauradas perante a L2 como pudemos apurar nas entrevistas. Esse fato traz presente tentativas frustradas devido à aprendizagem do passado por meio de um 
discurso pedagógico que não fez sentido para o sujeito-aluno ou, até mesmo, pela atitude do educador nesse processo de ensinoaprendizagem. Conforme mencionado anteriormente, os gestos, as expressões faciais ou a forma de falar, talvez tenham repercutido de maneira negativa para o discente, levando-o a criar barreiras no seu próprio percurso de aprendizagem. Nesse sentido, a maneira de corrigirmos algo, no momento da produção lingüística do educando, deverá vir carregada de cuidados, sobretudo com os educandos mais resistentes à correção.

O "erro" é um desvio disfórico, ou seja, não é obediente à norma, pode ser consciente ou não, dependendo do processo de aprendizagem em que o sujeito-aluno está e se houve uma conceptualização bem estruturada da norma na produção oral e/ou escrita. Sendo assim, não devemos agravar ainda mais a situação "defensiva" do educando, pois aumentaríamos o filtro afetivo, por essa razão buscamos encontrar uma maneira de corrigi-lo. Entretanto, o educando precisa ter consciência de seu "erro" e compreender que cometer erros é parte de um processo de aprendizagem. Quando o filtro afetivo é mais baixo, a resistência é menor e, conseqüentemente, ele terá menos receio de errar e a performance do sujeito-aluno poderá ser melhorada; no entanto, se o filtro afetivo for mais alto, a resistência será maior e o desempenho lingüístico poderá diminuir.

Convém ressaltar que o "erro" possui três facetas no processo de aquisição: mistake, slips e error ${ }^{33}$. O primeiro diz respeito à falta de atenção do educando ou quando ele não entendeu o que foi explicado, o segundo ocorre quando o educando comete um "lapso" não pela falta de conhecimento, mas por um momento houve uma "distração". O terceiro já é da ordem do "não-saber", talvez não tenha aprendido ou nunca houve uma correção de um determinado problema lingüístico.

33 2004, Fabiola Novella Massaro (fonte Braz-Tesol newsletter) 
Para que possam ficar mais claras as situações citadas anteriormente, tomemos, por exemplo, um sujeito-aluno que diga He like his job, diante disso, o educador utiliza-se de algumas técnicas para fazer com que seu educando tenha a oportunidade de corrigir-se, pois só dessa maneira é que poderemos avaliar o grau de compreensão da língua pelo educando. Se o educando perceber e, logo em seguida, corrigir sua frase ou, em uma outra frase, ele construir o mesmo tempo verbal (present tense) em terceira pessoa do singular com o "s", podemos dizer que houve um "lapso" (slips). Por outro lado, se o mesmo problema continuar persistindo durante os enunciados desse educando, provavelmente ele não entendeu, não lembra ou não está percebendo onde exatamente se encontra esse "erro" (mistake). Tendo em mente os problemas do educando, quando este estiver produzindo a L2, o educador analisa esses "erros" e emprega diferentes métodos para tornar a L2 cada vez mais clara e acessível às necessidades dele. São as diferentes estratégias, empregadas na construção do sentido de uma língua, que farão o educando construir um saber lingüístico.

Para tanto, o educador deve considerar o feedback das produções discursivas do educando. O feedback é necessário e importante para o desenvolvimento da competência no sujeito-aluno. O educador observa os problemas na produção escrita/oral e estuda uma maneira de sanar as deficiências encontradas, orientando o educando e, posteriormente, propõe alguns exercícios para avaliação de sua aprendizagem. Na aula seguinte, o educador procura saber se o educando teve algum problema na execução dos exercícios, sendo discutidas as dificuldades encontradas.

Como foi proposto anteriormente, o tempo de aula não é utilizado para a correção de exercícios, apenas para tirar dúvidas, exercitar a conversação e a compreensão auditiva na L2. Com o tempo, se o educando voltar a repetir os mesmos "erros", outros métodos são 
utilizados, além de fazermos perguntas que levem-no a inferir o que está errado nas construções frasais elaboradas por ele ou o educador pode aplicar exercícios que tenham um desvio da norma, com o propósito de fazê-lo pensar sobre o que estaria incorreto.

Geralmente, o educando adulto não gosta de fazer exercícios, sobretudo gramaticais; por essa razão é importante esclarecer a necessidade dos exercícios propostos, assim, o educador acabará mobilizando uma conscientização maior no educando sobre a L2. Para um bom aproveitamento do curso, o educador conversa com o sujeito-aluno sobre os procedimentos metodológicos a serem adotados, expondo com clareza os prós e contras para o sujeito-aluno, situando-o nesse processo de ensino-aprendizagem, mostrando-lhe uma visão mais ampla do curso.

Em alguns momentos do processo de aprendizagem, poderá ocorrer o desânimo do educando, por essa razão, o educador deverá relembrá-lo de seu objetivo com relação à L2. Esse objetivo norteará todo o processo desse sujeito e seu comprometimento com a aprendizagem será proporcional ao que ele deseja. O objetivo desse educando deve ser de conhecimento do educador desde o primeiro contato com ele, devido ao fato de o educador precisar ter um ponto de partida para elaborar um programa de acordo com as necessidades levantadas e possa, assim, trabalhar de forma mais personalizada com esse sujeito. Ao mesmo tempo, o educador também deverá deixar claro o que ele espera de seu educando durante o curso, visto que o processo de aquisição dependerá não só, mas também do sujeito-aluno, o qual deverá se comprometer com seu próprio processo, portanto um /dever-fazerl o que é sugerido pelo educador.

Dialogar é uma condição essencial para o bom aproveitamento do curso, sobretudo com adultos. Para tanto, o educador deve "negociar" as tarefas com o educando devido à questão de tempo de que ele dispõe, afinal ele não é apenas estudante, mas assume outros papéis no dia-a-dia, 
tais como: pai, esposo, profissional e participa de outras atividades, o que torna mais difícil uma dedicação ao seu Ov. Um acordo com relação às tarefas é uma solução para obter a realização das atividades sugeridas e, assim, fazer uma análise das necessidades (needs analysis) desse indivíduo. Todavia, o sujeito-aluno precisa lquerer-fazerl um esforço e organizar-se melhor para ir ao encontro do que ele se propôs desde o início do curso; o saber será otimizado pelo tempo dispensado com a L2 nos horários estabelecidos para o estudo e a duração do curso será maior ou menor, dependendo do que ele estabeleceu para si como critério e aperfeiçoamento da língua inglesa.

O educador não despreza o saber anterior do sujeito-aluno com relação à língua inglesa. Essas experiências são relevantes para traçar algumas estratégias de aprendizagem e serão um parâmetro para o educando compreender o seu próprio desenvolvimento na L2. Além disso, os saberes em outras áreas são sempre bem-vindos, para tornar as aulas interessantes por meio de assuntos relacionados à área de interesse do educando ou de seu trabalho. Todavia, o educador tem em mente que os históricos dos educandos são diversos, então não há uma metodologia única para trabalhar com esses indivíduos, mas a utilização de uma abordagem mais comunicativa amplia o grau de comunicabilidade do educando e essa abordagem não impede de ele usar métodos e técnicas diversos. A diferença configura-se na maneira que o educador irá elaborar a sua aula, tornando-a diferente e personalizada, mais próxima de seu objeto de estudo, ou seja, o educando.

O educando é o texto do educador, em que ele poderá ler as necessidades desse sujeito-aluno por meio de sua produção discursiva e, assim, elaborar uma maneira para ensinar e relacionar-se com o educando. $O$ educando dará a dimensão do que deve ser trabalhado nas aulas por meio de suas vivências, interesses e necessidades. Suas 
diversas maneiras de aprender são lidas e transformadas em objeto de estudo para serem utilizadas no processo bem como nas suas relações com outros universos de conhecimento, as quais são consideradas também para estabelecerem uma ligação com o saber lingüístico. Além disso, o educando é lido pela maneira de se comportar com relação ao seu objeto de estudo, por sua disponibilidade nos estudos, pelas colocações que faz na aulas e sua atitude corporal.

Nesse sentido também fará parte do papel do educador trabalhar na auto-estima do educando e motivá-lo quanto à sua relação com a L2, mostrando-lhe que as dificuldades que ele teve no passado e mesmo as dificuldades que vem encontrando fazem parte do processo de aprendizagem. Entretanto, somente será possível aprender se ele quiser, pois a demanda sempre vem do outro, o educador não pode ajudar a construir o que não se permite ou não se quer. O educador está comprometido com a construção de um saber lingüístico mesmo com aqueles indivíduos que não acreditam ser possível aprender ou não se sentem despertos para aprender em condições muitas vezes adversas. Dessa maneira, o educador trabalha, primeiramente, com a baixa autoestima do educando, se houver, ou com qualquer resquício de mal-estar do passado com relação à língua inglesa para depois despertá-lo para o lquerer-saberl.

Mesmo que o educador tenha um olhar mais técnico do que ocorre com o educando durante o processo de aprendizagem, ele precisa tomar cuidado para não perder de vista o fator humano. De fato, o educador parte da visão de mundo do educando para que, aos poucos, insira algo novo, criando meios para que ele possa perceber e (re)elaborar uma outra semiótica-objeto, agregando conhecimentos e, assim, o universo lingüístico e cultural desse educando será amplificado, tornando o indivíduo mais apto para entender e decifrar um mundo semioticamente construído. Assim 
sendo, parece-nos pertinente dizer que o educador, nesse processo de ensino-aprendizagem, é um arquiteto e engenheiro de seu ofício.

Para tanto, o educador respeita e compreende o processo desse indivíduo. É importante compreender a lógica desse sujeito, não existe somente a lógica do educador, considerando, a subjetividade desse educando, uma vez que ele ocupa um lugar social, tem desejos, interpreta o mundo de acordo com suas vivências, crenças, ideologias, valores e costumes, desenvolvendo uma atividade sobre esse mundo. Lacan (informação verbal) ${ }^{34}$ comenta sobre essa questão da subjetividade de um indivíduo, suas relações com o meio, seus desejos e relações com outros e consigo mesmo.

Em um primeiro momento, o educando coloca-se em posição disjuntiva ao seu objeto de valor, mantendo uma certa distância. Existe a possibilidade de o educador mudar essa relação, fazendo o educando mudar esse estado, levando-o a uma conjunção com seu objeto. Assim, a maneira que a língua será ensinada ao outro, diferentemente de seu passado, poderá contagiar o educando, fazendo-o interessar-se mais pelo saber lingüístico e, assim, ele passará a disponibilizar-se para estudar, modificando seu modo de pensar, pois passa de um regime de disjunção à conjunção e, posteriormente, à união, integrando o seu universo lingüístico ao novo elemento semiótico.

Diante disso, o professor-educador precisa construir uma boa estratégia de ensino, ou seja, um discurso pedagógico que seja da ordem do contato sensível e, ao mesmo tempo, construa um saber lingüístico, visto que tanto o educador quanto o educando estão numa relação e essa só poderá ser estabelecida se o educador compreender a maneira que o educando articula aquele saber. Portanto, o educador precisa encontrar um

$34 \quad$ Anotação das aulas de Psicanálise e Educação Inclusiva, ministradas pela Profa. Dra. Leny M. Mrech na Faculdade de Educação da Universidade de São Paulo, em 2003. 
modo de fazer o educando ajustar-se ao seu objeto, levando-o a abrir possibilidades na construção de seu saber lingüístico.

Com o passar do tempo, aquilo que parecia difícil começará a fazer sentido e tornar-se-á prazeroso, pois foi estabelecida uma experiência real e dinâmica com o objeto de valor. Uma experiência progressiva que começa a descobrir uma outra relação com o objeto, levando o sujeitoaluno a uma relação de ajustamento positivo; contudo, o educador precisa instaurar essa relação, "orquestrando e afinando" esse sujeito. Para tanto, é necessário que seja estabelecida uma doação de ambos os sujeitos envolvidos nessa relação de ensino-aprendizagem. Se essa relação interpessoal for agradável, o educando passará a "tomar gosto" pelo seu objeto de estudo e, dessa forma, acabará comprometendo-se com o seu saber lingüístico, ou seja, irá buscar outras formas de manter um contato com a língua inglesa.

Fazer o outro gostar, educando-o a olhar o "objeto de valor" por uma outra óptica bem como levá-lo a comprometer-se com sua aprendizagem deve ser estabelecido no relacionamento entre educador e educando para que ocorra um processo espontâneo e eficaz. Mas ambos precisam estar comprometidos com esse saber. Um querendo fazer o outro saber e o outro querendo saber o novo. Talvez o /querer-aprender/ do sujeito-aluno seja mais um /dever-saberl do que um lquerer/ real, assim sendo o educador precisará compreender o que mobiliza esse indivíduo ao /querersaberl a L2. O educador é que deve suscitar em seu educando um /querersaberl por meio da "sedução", ou seja, modalizando o modo de pensar desse sujeito-aluno, podendo assim, criar nesse sujeito uma outra dinâmica em seu /fazerl e que, aos poucos, ele irá tornar-se mais participativo em seu próprio processo, transformando aquele /deverl em lquererl, pois a L2 passou a ser mais interessante, prazerosa e, sobretudo, passou a fazer sentido. A fala desse educador credita ao educando um 
mundo possível e bem diferente do que ele havia estabelecido anteriormente sobre a língua ou sobre o papel do educador.

Um bom educador produz no outro tanto um /querer-saber/ quanto um lquerer-fazer/ e faz o outro /fazer/ sem precisar utilizar de uma linguagem persuasiva negativa por meio da manipulação (intimidação ou provocação), pois leva o outro a um regime que vai além da junção, uma união com o Ov. Esse educador contagia o outro pelo seu ethos, ou seja, pela maneira que ele constrói um discurso pedagógico, formando um outro simulacro para o educando no lugar do antigo que se constituiu em um simulacro da possibilidade de aprender a língua inglesa. Dessa maneira, o educador desencadeia algo nesse sujeito semiótico (educando), ou seja, uma ação que advém de um estímulo desse educador-destinador de um saber, incitando-o a um /querer/ estudar, discutir e envolver-se mais em seu próprio processo. Um professor-educador mais empático e consciente das necessidades e receios de seu educando transmitirá mais confiança a ele e apagará aquele mal-estar do passado com relação à aprendizagem.

O educador utiliza-se do saber de seu educando como instrumento para mediar o novo saber, busca 'significações correlatas' para produzir nele um efeito de sentido desejado, pois irá partir de uma comparação possível, que é discriminada pelo seu sujeito-aluno prontamente e semiotizada de uma forma mais natural e próxima da visão epistêmica de mundo desse educando. Do fazer interpretativo desse sujeito, ele conseguirá tecer outras considerações sobre o universo lingüístico da L2 que deverá ser alimentado e realimentado continuamente e colocado à prova toda vez que produzir um texto falado ou escrito. Esse fazer interpretativo passará por filtros de percepção e fará mais sentido ou menos, dependendo do grau de conhecimento do educando, conseqüentemente do tempo dedicado aos estudos da L2. 
Assim sendo, o professor-educador propõe um percurso que seja mais interativo, criativo e instigante (recursos audiovisuais, mídias e outras tecnologias como a internet, vídeo, TV, rádio, DVD), que faculta ao educando um /querer/ construir seu saber paulatinamente. Não é uma prática aconselhável insistir em listas e mais listas de verbos ou frases prontas. O objetivo do discurso do educador é levar esse sujeito-aluno a descobrir o prazer em instruir-se e divertir-se com sua aprendizagem e mesmo depois de um dia estafante de trabalho, ele ainda poderá ter em suas aulas ou nas suas horas vagas disposição para estudar, trabalhando em seu próprio processo, uma vez que esse saber será uma ferramenta para ele intervir no mundo da forma que precisar. Quando a L2 passar a significar, o educando aprenderá bem mais depressa, sobretudo quando se sentir motivado.

Acreditamos que o professor-educador deve não só desenvolver suas práticas metodológicas, mas também estar em uma constante atualização de seu saber lingüístico. Além disso, o educador deve buscar conhecimentos de outras áreas do saber e que possam serem somadas ao seu saber lingüístico. Quanto mais eclético for o educador, melhor será o entendimento sobre o outro e sua observação vai sendo apurada, encontrando maiores possibilidades para ensinar e significar um universo lingüístico. Os diversos saberes podem dialogar perfeitamente com esse universo lingüístico numa prática pedagógica, desde que encontremos um liame entre eles. Os recursos de que o docente dispõe certamente não são somente a lousa e o livro didático, como foi possível observar em algumas aulas, vão muito além, exigindo, sobretudo, conhecimento e dedicação por parte do docente e essas atitudes exigem tempo e comprometimento do professor-educador. Saberes diversos amparam e ampliam a criatividade do educador, sobretudo a sua visão de mundo. Quanto mais sensível às mudanças tecnológicas e às tendências culturais, mais próximo estará 
esse professor-educador das necessidades de seu educando. É fundamental estarmos abertos ao novo.

Diante desse fato, a prática educativa deve ser estudada além dos limites de uma sala de aula. Faz-se necessário que o professor-educador esteja atento a isso, além de inserir-se nessa realidade, buscando outras práticas metodológicas e outros ambientes. Por isso, o educador busca um /fazer/ diferenciado, pensando em outras formas de transmitir esse saber por meio de mídias e outros meios tecnológicos para que o educando possa estudar por si mesmo.

Se conhecermos bem o sujeito-aluno, poderemos pensar em meios para melhorar seu desempenho na língua inglesa, que não se restringirá apenas aos manuais do professor, mas será ampliado e pautado na diversificação dos meios didáticos, e, por conseqüência, numa visão mais amplificada do mundo, tornando o aproveitamento na constituição de um saber lingüístico mais rico. Existem outros ambientes para trabalhar com o desenvolvimento de uma competência lingüística na formação do educando, como o teatro, cinemas, pubs, dentre outros lugares, a fim de que as aulas de língua inglesa não se resumam ao espaço da sala de aula, mas sejam sua extensão.

O rigor é necessário na prática educativa não apenas para aquele que ensina, como também para quem está aprendendo, porém é preciso que haja no educador algo que não é aprendido nos manuais ou nas universidades como a criatividade, o bom senso e a intuição. O educador desperta no educando a busca de outros saberes por meio de textos em inglês, deixando-o mais apto a diversas situações. Prática essa que faz o sujeito-aluno adquirir um vocabulário diversificado e com noção dos elementos lingüísticos da língua inglesa. Quando o educando começar a entender a articulação e a estruturação da língua nos seus diferentes contextos, permitiremos a esse educando expressar-se mais rapidamente 
na língua estudada; as significações acerca daquele universo lingüístico serão conceptualizadas mais facilmente, pois existe um liame entre a prática educativa e os textos estudados. A L2 tem uma função maior do que ser apenas utilizada para a comunicação, é um meio para outras informações acerca das coisas no mundo e uma forma de o educando adquirir outros saberes.

O educador, sabendo que ocorrem transposições da língua materna para a língua estrangeira e em posse de uma taxionomia de erros mais comuns do educando brasileiro e de suas dificuldades, propõe um olhar mais criterioso e sensível sobre o processo do educando, pensando, assim, em elaborar situações que envolvam os 'elementos correlatos' e outros aparatos metodológicos/tecnológicos, os quais possam intermediar situações que são difíceis para o educando compreender. Nesse contexto, não podemos esquecer que a internalização de um universo lingüístico somente ocorre quando o ambiente externo motiva algo no sujeito, ou seja, o meio propicia a interação desse sujeito-aluno com fatos, ações ou pessoas (relações interpessoais) e vivências do educando, que são pautadas no universo do sujeito-aluno (relação intrapessoal), colaborando para a conceptualização de um outro universo lingüístico.

Com o passar do tempo, o educador deve perguntar-se sobre o que vem despertando em seu educando e se a maneira que está ministrando suas aulas colabora na aprendizagem do sujeito-aluno, observando se está construindo um sentido da L2 para o seu educando. Se o educador não estiver atento às necessidades do educando, às dificuldades e ao grau de motivação dele, provavelmente esse sujeito-aluno levantará mais barreiras e distanciar-se-á cada vez mais de seu Ov. A relação do educador com o seu educando deve ser de sensibilidade, respeito e de exploração de seu potencial e a do educando com o educador deve ser de credibilidade, respeito e envolvimento em seu processo. 
Tendo em mente as modalidades discursivas que Orlandi estabelece, acreditamos que o discurso lúdico ${ }^{35}$ e aberto (livre circulação de idéias) seria a forma apropriada de interlocução entre o educador e o educando, visto que é uma forma aberta, democrática de discurso e, dessa forma, o educando irá sentir-se mais à vontade e apto a trocar idéias e discutir sobre a $\mathrm{L} 2$, pois percebe que neste tipo de discurso ele precisará ter uma participação maior, trazendo suas impressões a respeito da língua e de outros assuntos e, ao mesmo tempo, isso dará condições ao educador de perceber o que seu educando ainda tem dúvidas ou comete "erros".

Diante disso, o educador obterá informações do processo que acompanha e, assim, poderá pensar em abordagens didáticas diferentes, voltadas a cada educando, dando-lhe condições para otimizar sua performance tanto no discurso escrito quanto no oral. Dessa maneira, estabelecemos um diálogo entre educando e educador, um movimento contínuo, uma troca.

Infelizmente, as ações de alguns docentes parecem estar muito automatizadas, muito em conformidade com os anos de prática de ensino de língua inglesa; um senso comum toma conta desses docentes, que não percebem mais o outro e não estão mais tão sensíveis às suas necessidades. São docentes que parecem ter perdido a vontade de tornar o que se repete novo, sob uma nova perspectiva, de criar algo diferente do que fez no passado ou saber que o sujeito-aluno que está à sua frente, não é o mesmo de anos atrás, e cada novo discente traz consigo suas singularidades, as quais estão ancoradas em um histórico de vida e realidade completamente diferentes dos anos anteriores.

35 Segundo Orlandi, o discurso lúdico é aquele em que a reversibilidade, que é a troca de papéis entre locutor e ouvinte no discurso, é total opondo-se, dessa forma, ao discurso autoritário em que a reversibilidade tende a zero. (ORLANDI: 2003, p.154) 
Assim, quando a postura do docente se engessa, dificilmente ele estará aberto, desperto ao novo e ao outro, disposto, portanto, a interagir. Cabe ao professor-educador repensar o velho, criando o novo para cada educando ou grupo relacionado ao momento em que se vive. Lançar-se ao novo não é tarefa fácil, mas necessária. Quando o professor-educador se propõe a olhar com mais atenção sua própria aula, seu educando e a forma que ele mantém uma interlocução, acabará trazendo para perto de si o interesse do sujeito-aluno.

Outro dado importante, porém ignorado por alguns docentes, é a disposição das coisas e das pessoas no espaço físico. O discente enxerga na figura do Outro (educador) a "outra cena", ou seja, alguém que está em um "outro lugar", num "lugar simbólico", portanto, em uma posição diferente da que o educando se encontra. Então, quando observamos a disposição de carteiras dos educandos, à frente do docente, notaremos que essa disposição dos lugares acaba reforçando e reiterando o que o educando pensa com relação ao papel do docente na sala de aula. O docente parece não perceber que coloca o outro em um espaço disfórico, pois altura remete a uma hierarquia, um alto euforizado do ponto de vista do discente, portanto, ele possui um olhar disfórico de si próprio, que olha o Outro como aquele que detém um saber e que está em uma posição de verticalidade com relação a ele, ou seja, estão assimétricos.

Frente a isso, as aulas em que o educador se posiciona dentro de um círculo (aulas em grupo) ou se posiciona ao lado de seu educando (aulas individuais) parecem deixar o sujeito-aluno mais à vontade e participativo, colocando-o mais próximo de seu educador. A simples disposição das cadeiras ou da colocação do docente no espaço modificará esse lugar simbólico do Outro e irá instaurar uma outra relação entre os sujeito nesse circuito de ensino-aprendizagem. Até mesmo em aulas individuais, vemos, 
algumas vezes, que o docente se posiciona distante de seu(s) discente(s), pois se posiciona à frente dele(s), tendo a mesa como uma divisória imaginária, mesmo estando em um nível mediano com relação ao corpo e ao olhar do sujeito-aluno, entretanto, o docente ainda se posiciona espacialmente distante de seu discente.

Em princípio, essas situações estabelecidas na aula farão diferença na relação entre educador e educando, mesmo que passem despercebidas pelo sujeito-aluno, deveriam ser mais conscientes para o docente. A altura implica uma hierarquia do dizer e a verticalidade do olhar acaba delimitando o espaço, além de reafirmar, em alguns casos, uma entificação da figura do Grande Outro. A entificação leva a uma inacessibilidade. Para o educando, esse docente é um sujeito suposto saber, ou seja, um docente que detém um saber lingüístico suposto e que, apesar de estar capacitado a gerar um conhecimento num outro sujeito, não necessariamente pode estar disposto a entender as angústias, os objetivos ou dificuldades apresentadas pelo sujeito-aluno. Esse Grande Outro pode /parecer-estar/ próximo inicialmente, mas com o passar do tempo distancia-se, pois seu papel é transmitir conteúdos, não sendo capaz de instaurar uma relação "eu-tu" tanto espacialmente quanto no desenvolvimento de seu discurso pedagógico, pois não abre ao outro um espaço para considerações, constatações ou experiências, enfim, um diálogo e, quando o faz, é mínimo.

Diante disso, a produção oral ou escrita, especialmente a oral será prejudicada em vista de o sujeito-aluno não se sentir à vontade e, em alguns casos, não ser convidado a participar de sua própria aula, o que pode trazer, por conseqüência, o distanciamento de seu Ov, e, com o passar do tempo, o desânimo e a construção de simulacros negativos dele mesmo com relação à língua (incapacidade de aprendizagem ou acreditar ser tarde demais para aprender uma língua estrangeira), bem como o 
papel do docente, reafirmando aqueles antigos simulacros que causaram um mal-estar no seu percurso de aprendizagem da L2.

Um outro dado importante para o bom desempenho do educando em seu percurso de aprendizagem da L2 seria considerar a capacidade de atenção cognitiva de indivíduos que aprendem melhor no período matutino e outros que preferem aprender no período vespertino. Infelizmente, nem sempre é possível pensarmos num horário que o sujeito-aluno prefira, pois algumas vezes ele não poderá dispor desse horário, por motivos pessoais ou profissionais e, talvez, o educador não tenha disponibilidade dentro de sua grade de aulas. Dessa maneira, o discente terá de adequar-se ao horário disponível, o que não seria desejável se levarmos em conta a questão da capacidade de atenção e de memorização, que serão prejudicadas pelo cansaço.

Diante do exposto, no que diz respeito ao papel do educador, é importante considerar:

> Indivíduo: o educando é um ser singular, o que significa dizer que a maneira pela qual desenvolvemos um procedimento metodológico com um educando não necessariamente será interessante ou eficaz para o outro. Devemos pensar para quem desenvolvemos uma aula, qual é o histórico e o perfil do educando, para que possamos ministrar uma aula mais significativa;

> Material: o material a ser usado pelo educador e, em alguns casos, a ser desenvolvido (produzido) por ele, deve ser coerente e consistente ao conteúdo que será explanado. Se o material for ao encontro das reais necessidades do educando e ao que ele gosta, tanto melhor para o desenvolvimento da língua inglesa; 
> Simplificação da informação: quanto mais claro, simples e direto for o educador em sua explicação, melhor será a compreensão do educando. Com o tempo, as explicações podem ser mais pormenorizadas, mas, primeiramente, precisamos construir uma base estrutural de conhecimento lingüístico estável e de qualidade, em vez de quantidade de informações; e

> Postura do educador: a maneira pela qual o educador se relaciona com o educando e a forma como ensina a L2 não passam despercebidas pelo educando, mesmo que inconscientemente. $O$ 'olhar sensível' às fragilidades do outro e às suas dificuldades serão sempre bem-vindas. O comprometimento que um docente tem com sua profissão é percebido pelo discente por meio do comportamento corporal (sua gestualidade e feições), do tom de voz (monocórdico ou não) ou pelo discurso (explicações evasivas, sem vontade ou ríspidas) desse educador. Além disso, hoje em dia é muito comum que as aulas sejam ministradas em empresas (in-company classes), razão por que o educador deve saber como vestir-se adequadamente (dress codes) para um ambiente de trabalho, visto que a aparência é um dado real e habitual nessas companhias.

Após o contrato estabelecido entre educador e educando, o percurso de ensino-aprendizagem será avaliado pelo sujeito-aluno, que irá analisar se o percurso foi sancionado positiva ou negativamente no tocante ao discurso pedagógico e atitude do docente perante a transmissão da L2. Assim, o contrato estabelecido, inicialmente, será considerado nesse percurso da sanção de um saber lingüístico, verdadeiro, falso, mentiroso ou secreto numa articulação do ser vs parecer no quadrado semiótico: 


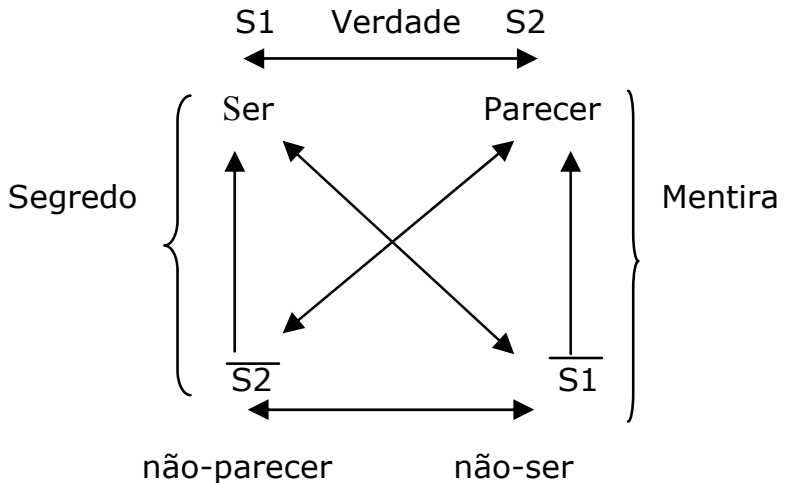

Falsidade

Figura 7: Quadrado Semiótico ${ }^{36}$ - Ser vs Parecer

Diante disso, teremos um percurso de transmissão de um saber, pautada nas seguintes articulações: quando é e parece, temos a verdade, quando não é e não parece, temos a falsidade. Quando parece mas não é, existe a mentira, e, quando é mas não parece, existe um segredo.

\subsection{Relação do educando com o saber}

A resistência ao novo é algo constante nesses adultos que precisam aprender um novo idioma. É muito provável que essa resistência tenha se estabelecido devido aos "traumas" do passado relativos a sua aprendizagem da L2. Contudo, para que o educando se envolva com o novo saber, precisará construir um olhar diferenciado nesse processo de ensino-aprendizagem, o qual será apresentado, primeiramente, pelo educador e, posteriormente, esse olhar deverá ser compartilhado pelo educando também. $\mathrm{O}$ medo parece vir acompanhado dessa resistência ao novo, justamente por ele ter lidado de uma forma desagradável com a língua e/ou com o docente no passado e, conseqüentemente, acabar não gostando da L2 e, assim, rechaçar o que não entende ou não consegue lidar.

36 Greimas e Courtés, 1979, p. 488 
Sabemos que é mais difícil ensinar um idioma àquelas pessoas que procuram aprender inglês só para conseguir satisfazer um mercado de trabalho competitivo, notadamente as que precisam, porém não querem e devem estudar. Assim, o que impulsiona o indivíduo é uma colocação melhor no mercado na maioria dos casos. Devido a esse fato, o educando não deve perder de vista o Ov , o qual deverá ser lembrado durante todo o processo de aprendizagem, uma vez que a motivação desse sujeito-aluno diminui com o tempo e o que era importante passa a ter menos importância e, por isso, ele afasta-se do Ov.

Quando esse educando se sente pressionado pelo docente ou pela empresa entra em pânico, nesse sentido passa a não progredir ou, simplesmente, despreza o objeto de estudo. A atitude do sujeito-aluno com o seu Ov é relevante para o processo de aprendizagem, sobretudo quando ele conversa com o educador sobre o que the incomoda, sobre suas dificuldades ou outras questões que são suscitadas nesse processo. Entretanto, nem sempre o educando percebe essas questões durante sua aprendizagem, daí o educador precisar questioná-lo a respeito de seu processo com a L2. Quando temos um docente que respeita essa insegurança do educando que, em princípio, vem com as impressões de um passado não tão agradável, o segundo passo dependerá da atitude do educando, pois ele precisará tentar ir além dessas primeiras limitações, que foram impressas em suas experiências e trabalhar com suas deficiências da L2, superando seus receios e permitindo-se aprender sob uma outra perspectiva para que um novo saber possa ser instaurado.

Tomemos, como exemplo, o seguinte enunciado do educando:

- Eu quero aprender inglês.

$\mathrm{Ou}$, 
- Eu preciso aprender inglês.

Enquanto um enunciado expressa um /querer/ que partiu de desejo do próprio educando, o outro enunciado expressa uma necessidade que, provavelmente, partiu do Grande Outro (mercado de trabalho). Quando o sujeito-aluno diz querer falar inglês ou precisar falar, ele atribui a esses enunciados uma característica, que é da ordem do /saberl, e que só poderá ser adquirida se for trabalhada dentro de um processo lógico, passando por etapas que o levarão a uma transformação de valores modais durante o percurso de ensino-aprendizagem, sendo manifestado no discurso oral ou escrito. Além disso, o sujeito-aluno precisará passar por algumas etapas de construção da língua para chegar a uma conjunção com seu Ov ( $\mathrm{OV}=$ saber lingüístico; $\mathrm{O}=$ língua e $\mathrm{V}=$ saber $) \mathrm{e}$, conseqüentemente, obtenha uma sanção positiva em sua aprendizagem.

Vejamos o seguinte octógono semiótico das situações em que o sujeito-aluno poderá encontrar-se numa relação com seu Ov, ou seja, em sua busca pelo saber lingüístico:

Busca de um saber lingüístico

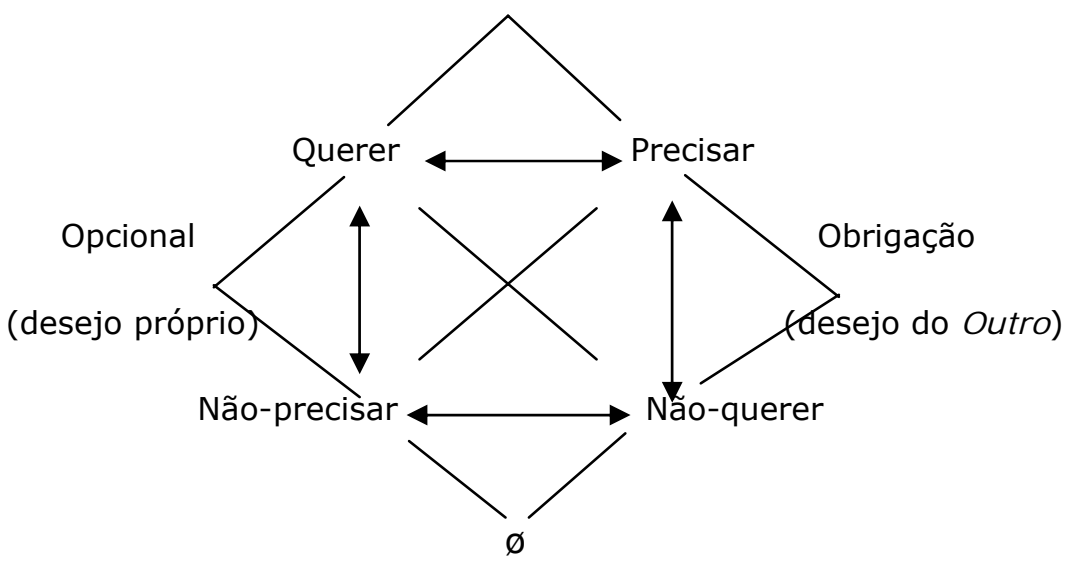

Indiferença

Figura 8: Octógono semiótico do educando numa relação com o Objeto de Valor 
1. Situação de desejo ou necessidade;

2. Situação de necessidade, mas não partiu de seu desejo;

3. Situação, em que não há nem desejo nem necessidade; e

4. Situação de um querer ou desejar, sem ter uma necessidade, mas quer aprender por opção.

O metatermo, busca de um saber lingüístico, sustenta uma tensão dialética entre querer vs precisar; assim, teremos, respectivamente, seus contraditórios que são o não-querer vs não-precisar. Na dêixis negativa, configura-se uma situação de necessidade, um /dever-saberl imposto pelo desejo do Outro, entretanto não existe o desejo, um querer verdadeiro. Do lado oposto, temos a dêixis positiva, em que o sujeito-aluno não precisa ir em busca de um saber lingüístico, contudo quer um conhecimento, um lquerer-saberl, um desejo que parte dele mesmo. No termo neutro, temos aqueles indivíduos que se colocam à margem de uma sociedade e que não precisam e nem querem ter um conhecimento lingüístico.

Em princípio, o sujeito-aluno não possui um /saber-fazerl (uma competência) ou até mesmo um /poder-fazerl (fazer pragmático), uma vez que precisa de elementos lingüísticos básicos da L2 para começar a lidar com a língua e adquirir aqueles valores modais, já comentados no desenvolvimento deste trabalho. O educador tem a posse desses operadores sintáticos (valores modais), sendo ele quem faz a ligação com um /saber/ e um /poder-fazer/ lingüístico com e para o educando, transformando os valores modais. Dessa forma, o sujeito-aluno transforma um /querer-fazer/ em um /saber-fazer/ com a praxe. Enquanto o educador busca, como objeto de valor, transmitir um saber lingüístico para o seu educando, este busca a aquisição de um saber lingüístico. A sanção positiva do Ov tanto de um quanto de outro só poderá ocorrer mediante um 
percurso consciente e satisfatório de todos os sujeitos envolvidos nesse processo de ensino-aprendizagem.

Entretanto, o contrato firmado entre ambos poderá se perder durante o percurso. Analisando as seguintes situações, temos:

1- O educador trabalha em conjunto com seu educando, em busca da melhor maneira para ajudá-lo a construir um saber lingüístico. Contudo, o educando não participa de seu processo, ou seja, não estuda ou não faz o que é sugerido pelo educador. Provavelmente, a sanção será negativa tanto para um quanto para o outro, não por culpa do docente, pois faz o que se espera de um educador consciente. Mas, o discente precisa ser responsável pelo seu próprio processo, visto que a demanda advém do educando, pois ele precisa /querer-fazer/ algo para alcançar seu Ov.

2- Sabemos que muitos docentes não se preocupam tanto com o outro, apenas transmitem conteúdos sem observar a aprendizagem do sujeitoaluno, atitude essa que para esses docentes poderia ser uma sanção positiva. Por outro lado, seria uma sanção negativa para o discente, levando-o a uma desmotivação e, até mesmo, a criar uma barreira ou repulsa pela língua, uma vez que se acha incapaz de aprender a L2 ou acredita que a idade prejudica sua aprendizagem. Geralmente, o que rechaçamos é o que não podemos compreender, conseqüentemente, acabamos não gostando. Como já havíamos dito, o comportamento do docente na maneira de transmitir um saber reflete e influi diretamente no processo de seu sujeito-aluno. Nesse caso, é muito provável que esse docente acredite que está cumprindo o seu papel, assim, teremos uma sanção positiva para ele e negativa para o discente. Do ponto de vista do docente, o sujeito-aluno não entende porque não quer, não tem vontade de aprender. 
Para que se instaure um contrato ideal, ambos precisam estar envolvidos nesse processo. O educador procurando a melhor maneira de transmitir seu conhecimento segundo o universo sócio-lingüístico-histórico e cultural de seu educando e, por sua vez, esse deveria participar ativamente de sua formação tanto durante a aula quanto em casa, por meio de seus estudos ou buscando outras formas de manter contato com o idioma e, até mesmo, requisitando outros meios para trabalhar com suas dificuldades.

Assim, num determinado momento, o educando terá de passar pela prova qualificativa a ser estabelecida durante o percurso do educando. Esse percurso permitirá que ele se qualifique cada vez mais pelo tempo dedicado desde que o educando faça o que foi proposto para o desenvolvimento de sua competência lingüística. Posteriormente, será estabelecida a prova glorificante, na qual o educando começa a entender a língua inglesa e passará a manifestá-la na expressão escrita e oral (nível discursivo).

A atitude do educando poderá ser, num primeiro momento, da ordem das volições, ou seja, do querer, mas para que ele realmente se envolva nesse processo, o educando precisará desejar, pois o desejo é da ordem do "mover-se para", implica ação e para isso "eu me disponho a". A maneira que o sujeito-aluno irá conceptualizar esse novo saber lingüístico está estritamente relacionada ao quanto ele deseja seu Ov. Compreender novos conteúdos de uma outra cultura, que possui estruturas sintáticas, semânticas, morfológicas e fonológicas distintas de sua língua mãe implica um estudo criterioso, considerando não somente o seu funcionamento lingüístico, mas também os valores e costumes da cultura estudada.

O processo de aprendizagem do educando assemelha-se muito ao processo de aquisição de linguagem de uma criança que, aos poucos, se apropria da língua, adquirindo um modo de comunicar-se com o meio. Em 
princípio, usa também formas simples, comete erros de pronúncia, de gramática (desvios da norma) e está sempre elaborando e reelaborando o que aprendeu, tentando fazer outras combinações com as regras daquela língua, chega, até mesmo, a inventar novos vocábulos. Entretanto, a criança ainda não criou barreiras, ou seja, a sua relação com o mundo é de descoberta e, assim, permite-se errar, testar, buscar mais conhecimentos.

Apesar de notarmos algumas semelhanças no modo de aquisição de linguagem entre crianças e adultos, o adulto já possui um amadurecimento cognitivo capaz de tecer seus próprios juízos e inferir sobre o que lhe é ensinado mais rapidamente, em particular na abstração de um conceito ou situação, além de possuir meios para aperfeiçoar sua aprendizagem, mas isso dependerá de um envolvimento desse educando, podendo ser maior ou menor com o Ov.

O educando-adulto tem uma relação diferenciada com o saber, pois muitas vezes é submetido ao querer do Outro para conseguir o que almeja. Dificilmente um adulto que pretende aprender a língua inglesa está em uma sala de aula porque ele "quer", geralmente é porque ele "precisa", ou seja, está aprendendo pelo "dever", o que torna o trabalho do educador mais difícil e desafiador, visto que é mais fácil lidar com pessoas que gostam da L2 e queiram aprendê-la por vontade própria. Em princípio, a busca de um saber para cumprir um /dever/ parece ser um aspecto negativo na aprendizagem, contudo acabará por incitar um movimento no outro, levando-o a fazer algo em benefício de si próprio. Tornar-se-á um aspecto negativo quando o educando não encontrar uma motivação para estudar a L2 ou não se comprometer com sua aprendizagem.

Um de nossos educandos, que é piloto particular, ainda encontra muitas dificuldades de colocação numa companhia aérea. Ele só poderá fazer parte do quadro de funcionários da empresa se tiver um bom nível da língua inglesa, sobretudo em sua área. Todavia, o inglês técnico ele 
conhece bem, o que não consegue é expressar-se no discurso oral e/ou escrito. As provas que ele precisará realizar pedem uma competência tanto escrita quanto oral e essas são suas dificuldades.

No campo da aviação, em particular na função de comandante de uma aeronave, somente o indivíduo que mostre ser competente na língua inglesa terá a oportunidade de exercer um cargo de responsabilidade, dentro da companhia aérea. Como esse educando já havia tentado outras vezes, sua auto-estima e motivação foram abaladas, justamente pelo fato de não conseguir uma colocação por causa da língua inglesa. Entretanto, a escala de vôos de um piloto não colabora para um desenvolvimento satisfatório da L2, devido aos horários imprecisos a que um piloto é submetido. Daí, o processo de ensino desse educando acabar sendo mais complicado com relação ao seu horário, dificultando, assim, uma rotina de estudos. De qualquer maneira, ele precisará lidar com essa questão de outra forma, a qual poderá ser negociada com seu educador.

Acreditamos na instauração de um conflito quando o educando percebe que sua liberdade de escolha é tolhida. A sociedade diz o que ele "deve saber" para ser aceito por ela e, independente de sua vontade, ele "precisará saber", pois sua colocação no mercado só será aceita se ele tiver o saber lingüístico, independente do seu /querer/. Diante desse quadro, podemos constatar os seguintes conflitos nesse processo: Natureza vs Cultura; Universo Individual vs Universo Coletivo.

\subsection{Relação com o domínio da cultura}

O termo cultura é entendido sob dois aspectos, um deles é a instrução, conhecimentos adquiridos e, o outro, de cunho antropológico, ou seja, é associado à idéia de um sistema de valores, crenças e atitudes de um povo. No processo de ensino-aprendizagem esses aspectos devem ser considerados na aquisição da L2 pelo educador. 
Desde o nascimento do ser humano, ele recebe inúmeras informações e reage a elas. O ato de uma ação sobre as coisas faz o homem entender e aprender aquilo que o cerca, por isso acaba sendo estimulado a agir nesse meio. O conhecimento é, aos poucos, amplificado, pois parte das experiências do indivíduo e, se essas forem diversificadas, tanto melhor para o alargamento de visão de mundo desse sujeito.

Quando criança, o homem aprende observando o Outro e captura situações que são percebidas e discernidas no tocante a um objeto ou a uma ação. Naturalmente, a linguagem vai se instaurando no modo de falar, agir e de ser. Quando estimulado por aquilo que o cerca, amplia o conhecimento e ganha um capital cultural que irá permear sua vida e refletirá em tudo o que fizer, uma vez que ele é o produto dessa formação cultural do passado. Se o homem não tiver oportunidades de entrar em contato com diferentes linguagens ou conhecimentos diversos, dificilmente conseguirá ter discernimentos outros ou mais aprofundados para expandir o seu capital cultural e inferir sobre uma determinada situação, conseqüentemente, aprender tornar-se-á mais complexo. Conhecer outras formas de linguagem é uma maneira de agregar experiências sobre si mesmo e sobre as coisas e pessoas no mundo.

É interessante notar que sem conhecimentos outros, o indivíduo tornase mais limitado e sua visão de mundo também. Por outro lado, quando buscamos desenvolver no sujeito uma vivência por meio de outras linguagens, agregando a L2 a elas, o educando aprende mais rapidamente e com facilidade. Essas experiências criam modelos mentais mais diversificados e ricos em conteúdo, que permitem ao educando uma visão ampla para conseguir elaborar melhor o que vem aprendendo. Quando limitamos nossos modelos mentais, acabamos por limitar o nosso olhar sobre as coisas no mundo. 
Aprender uma língua estrangeira é não só aprender seu sistema lingüístico, mas também entender a maneira que o idioma constrói a visão de mundo daquela cultura, daquele universo lingüístico. É falar de valores, ideologias e crenças que são construídos naquela cultura. Tais categorias podem ser observadas por meio de outras semióticas-objeto que demonstram a maneira que um determinado povo lê e recorta o mundo. Os filmes, o teatro, a literatura, a música, a dança são exemplos de semióticas-objeto, que vinculam um modo de expressão de uma cultura e corroboram, também, para uma prática educativa mais ativa e estimulante na formação lingüística do educando.

É notório que precisamos de um capital cultural para nos desenvolvermos cognitivamente. O nível cultural de uma pessoa é muito importante para a sustentação dos saberes, ampliação e (re)alimentação de um sistema lingüístico. $\mathrm{Na}$ aprendizagem, o acervo cultural de um indivíduo o ajudará na elaboração do pensamento, assim, o grau de abstração será amplificado, e o sujeito terá condições de fazer inferências em situações novas, com mais facilidade. A cultura e educação estão imbricadas, não existe cisão entre elas.

O papel do educador é fundamental nesse processo cultural, na interdisciplinaridade dos diferentes "saberes"; o saber cultural é cultivado pelo educador, para dentro de seu educando, instigando-o a ir buscar, investigar e fundamentar algo. Por outro lado, o educando também é responsável pela sua formação cultural. $\mathrm{O}$ indivíduo desprovido de capital cultural tem mais dificuldade em interagir, trocar idéias e desenvolver-se, por esse motivo é necessário que o educador motive em seu educando outros saberes; assim, o educador terá a possibilidade de discutir sobre assuntos diversos e pedir para o educando pesquisar sobre eles também. 
Atividades suplementares como peças teatrais, óperas, ballets, exposições são atividades que deveriam ser incentivadas pelo educador e, após esses eventos, poderá propor uma atividade utilizando a L2. O saber cultural age na ontogênese do ser e, qualquer saber que for colocado ao educando, será mais fácil para ser argumentado e decodificado por ele, pois passará a ter um significado para esse sujeito-aluno.

A bagagem cultural do educando deve sempre ser considerada para que o educador possa fazer bom uso dela e depois expandir o conhecimento do educando. De nada adiantará darmos um exemplo fora da realidade do sujeito-aluno, sem que ele tenha vivenciado ou tido alguma noção do que é explanado pelo seu educador. As associações que são acionadas pelo educando dependem de sua bagagem histórica, cultural e lingüística para poder construir uma nova língua e, cada vez mais, ele irá aumentar seu universo lingüístico pelo que foi internalizado, mas o próprio educador deverá prover o educando de condições que o levem a fazer tais redes de associações. Quanto mais explícita for a transmissão da $L 2$, tanto melhor serão as representações que o educando terá, respondendo-as prontamente.

O interesse do educando só poderá ser cultivado se houver uma educação para tal, a ser estimulada em casa (instrução cultural diferenciada) e/ou por meio de instituições de ensino, provendo aos seus educandos assuntos que estão além dos livros e que poderiam ser uma extensão da sala de aula como é o ensino das instituições japonesas. Não existem atalhos para esse tipo de aquisição cultural que demanda tempo e um custo capital tanto para a instituição de ensino/docente quanto para o sujeito-aluno. Nesse sentido Bourdieu (1998, p. 61) diz que

Se a ação indireta da escola (produtora dessa disposição geral diante de todo o tipo de bem cultural que define a atitude "culta") é determinante, a ação direta, sob a forma 
do ensino artístico ou dos diferentes tipos de incitação à prática (visitas organizadas, etc.), permanece fraca: deixando de dar a todos, através de uma educação metódica, aquilo que alguns devem ao seu meio familiar, a escola sanciona, portanto, aquelas desigualdades que somente ela poderia reduzir. Com efeito, somente uma instituição cuja função específica fosse transmitir ao maior número possível de pessoas, pelo aprendizado e pelo exercício, as atitudes e as aptidões que fazem o homem "culto", poderia compensar (pelo menos parcialmente) as desvantagens daqueles que não encontram em seu meio familiar a incitação à prática cultural.

Essa questão do capital cultural deveria ser cultivada em nossa sociedade, colocando um fim às desigualdades de desempenho escolar de crianças, jovens e adultos provenientes de classes sociais distintas e que acabariam por beneficiar esses indivíduos no futuro, na obtenção de melhores oportunidades no mercado de trabalho $e$, conseqüentemente, estaríamos formando indivíduos com um outro tipo de instrução cultural, mais completa, ampla e adequada. Bourdieu (1998, p. 75) afirma que:

O capital cultural é um ter que se tornou ser, uma propriedade que se fez corpo e tornou-se parte integrante da "pessoa", um habitus. Aquele que o possui "pagou com sua própria pessoa" e com aquilo que tem de mais pessoal, seu tempo". (...) "Não pode ser acumulado para além das capacidades de apropriação de um agente singular; depaupera e morre com seu portador (com suas capacidades biológicas, sua memória, etc.). Pelo fato de estar ligado, de múltiplas formas, à pessoa em sua singularidade biológica (...)

A aprendizagem impulsiona o desenvolvimento intelectual, conseqüentemente, a escola e/ou educador deveriam ter um papel essencial na construção do ser psicológico dos indivíduos, mas isso só acontecerá de forma adequada quando o educador conhecer o seu educando, ou seja, na maneira pela qual ele consegue desenvolver melhor sua aprendizagem, assim, o educador poderá dirigir o ensino para etapas intelectuais ainda não alcançadas ou desenvolvidas pelo sujeito-aluno, 
funcionando como um propulsor de novas conquistas intelectuais. Para Vygotsky (2002 apud, OLIVEIRA, p. 62), "o único bom ensino é aquele que se adianta ao desenvolvimento", nesse sentido, o educador deve interferir no desenvolvimento de seu educando, promovendo avanços no desenvolvimento do indivíduo na aprendizagem da L2.

Outro aspecto da cultura, além do conhecimento de "atividades e desenvolvimento intelectuais de um indivíduo" (sentido subjetivo), é o aspecto da cultura enquanto povo, sociedade (sentido etnológico). Nesse sentido Aurélio (1999, p. 591) define:

cultura é o complexo dos padrões de comportamento, das crenças, das instituições e de outros valores transmitidos coletivamente e típicos de uma sociedade; (...)

Do ponto de vista da antropologia, o Aurélio ${ }^{37}$ define, o seguinte:

cultura é um conjunto complexo dos códigos e padrões que regulam a ação humana individual e coletiva, tal como se desenvolvem em uma sociedade ou grupo específico, e que se manifestam em praticamente todos os aspectos da vida: modos de sobrevivência, normas de comportamento, crenças, instituições, valores espirituais, criações materiais, etc.

Sendo assim, um povo representa e interpreta o mundo de formas diferentes de cultura para cultura, dentro da mesma cultura e de indivíduo para indivíduo; para mediarmos um saber lingüístico precisamos ter como base essa linha de pensamento, pois o que faz sentido para uma cultura necessariamente não fará para uma outra. Nesse sentido, tomemos como exemplo o filme "Ikingut- $\mathrm{Na}$ terra do Gelo" ${ }^{38}$ que retrata um povoado lutando pela sua sobrevivência durante um rigoroso inverno e esse povoado aprende com um garoto, vindo da Groenlândia, como sobreviver

\footnotetext{
$37 \quad$ Idem

38 "Ikingut - Na terra do Gelo" dirigido por Gisli Snaer Erlingsson na Islândia em 2.000, filme que se passa no final do século XVII, num vilarejo localizado na costa norte da Islândia.
} 
num lugar inóspito, ensinando às pessoas dessa pequena cidade, a distinguir os diferentes tipos de neve ou a maneira correta de manuseá-la na construção de iglus, sendo que o garoto chamado Ikingut possui percepções e saberes diferentes daquelas pessoas que não haviam desenvolvido tais percepções no meio em que viviam anteriormente.

Ou, então, se pensarmos que, numa cultura oriental, as percepções de matizes do claro e do escuro são bem distintas e fazem diferença na sua maneira de representação plástica do mundo. Assim, não nos causaria espanto se ao entrarmos numa loja para comprar tinta preta, escutássemos a seguinte pergunta: "Qual cor preta?" Dessa forma, quando falamos de uma língua estrangeira, a cultura vem vinculada a ela, são aspectos inseparáveis; assim, a língua não é só um meio de comunicação, mas também uma forma de pensar e agir de um povo.

Falar em transmissão de L2 implica construir um mundo com um olhar diferente sobre as coisas nesse mundo, isto é, uma construção de sentido, pautada no meio em que vive aquele povo, a qual será reinterpretada e reelaborada pela visão de uma outra cultura. Portanto, além de pensar na construção de mundo da L2, devemos pensar no educando não só como sujeito interpretante, mas como um sujeito em falta e que traz consigo toda sorte de experiências e vivências de um meio.

Assim sendo, ensinar um idioma implica levar o sujeito-aluno não apenas a conhecer a língua em si, mas também fazê-lo ter um contato com o universo cultural da $L 2$, um entrosamento com a maneira que aquele povo pensa e organiza suas idéias. Quanto mais o educando for exposto às diferentes situações lingüísticas e culturais, maior e melhor será seu repertório tanto da L2 quanto da própria cultura. Desse modo, conseguirá entender mais a língua aprendida e construirá um sentido dela para si, visto tomar suas experiências anteriores como parâmetros. 


\subsection{Considerações acerca do sistema de ensino de língua inglesa}

\section{para adultos}

O primeiro contato que temos com a língua inglesa é durante o ensino fundamental (ciclo II), não sendo um ensino que podemos chamar de significativo, uma vez que não nos permite ter um bom conhecimento do idioma, salvo algumas instituições de ensino que possuem profissionais com formação específica para trabalhar a L2 e exigem de seus educandos uma competência significativa, provendo esse sujeito-aluno de uma boa bagagem lingüística da L2.

Contudo, o mercado das grandes corporações com suas transações internacionais importantes exige uma competência lingüística de seu funcionário na L2 ou para aquele indivíduo que queira uma colocação nesse mercado tão competitivo; a língua inglesa é a língua franca do mundo empresarial, seja a variante americana ou inglesa. Alguns discentes tiveram a sorte de entrar em escolas de idiomas desde criança, outros estudaram no exterior ou em colégios americanos no Brasil, o que facilitará a inserção desses indivíduos no mercado. Todavia, temos um grande número de indivíduos, já na fase adulta, que vieram daquele sistema falho de ensino de línguas, comentado anteriormente e encontramse numa situação difícil, nesse momento, em que tempo é escasso e seus desejos são outros, mas precisam aprender a língua o mais rapidamente possível, mesmo que não a usem no seu dia-a-dia de trabalho. Portanto, o sujeito-aluno acaba tendo de ir em busca de escolas de idiomas ou professores particulares para adquirir um conhecimento lingüístico.

Uma escola de idiomas visa ensinar uma língua estrangeira, entretanto, o que difere uma instituição da outra, é a sua abordagem metodológica, docentes especializados, o material didático utilizado e a sua infra-estrutura. Assim, o indivíduo que busca uma escola de idiomas pode procurar por uma abordagem diferenciada, entretanto, não podemos 
esquecer que o fator tempo, custo e proximidade são considerados pelo futuro discente; algumas vezes, esses fatores são mais importantes para o indivíduo, deixando de lado a qualidade de ensino e a metodologia, os quais ele não saberia como avaliar, pois crêem numa instituição de ensino e essa leva o discente a acreditar num diferencial de mercado, seduzindo-o por meio de uma projeção identificatória. A instituição é para o indivíduo um lugar que sancionará um saber lingüístico e, dessa forma, irá capacitálo para ser inserido no mercado de trabalho ou ser aceito numa universidade, na qual pretende fazer seu curso de especialização ou pósgraduação.

Podemos observar que os treinamentos e/ou planejamentos feitos pelas escolas de idiomas colocam em muitos casos uma só maneira de transmitir a língua inglesa dentro de um método pré-estabelecido, com algumas exceções. Parece não haver uma preocupação em saber quem é o sujeito que está aprendendo a L2. De qualquer forma, trabalhar com um método específico não anula o fato de o docente interagir com seu educando, observando suas deficiências e convidando-o a ter um olhar mais analítico sobre seus acertos e erros, incentivando-o a participar de seu próprio processo de aprendizagem e de utilizar recursos outros para conseguir resultados melhores na forma de lidar com esse saber.

Portanto, o educador precisa pensar, primeiramente, na realidade do sujeito-aluno a quem se destina um saber, pensar no processo sóciohistórico-lingüístico e cultural desse indivíduo e da sociedade em que ele se insere para que a prática do ensino de uma língua estrangeira não seja pautada apenas em modelos pré-estabelecidos pelos livros didáticos ou pelos cursos ministrados aos professores de língua inglesa, mas que sirvam para agregar idéias e modificá-las de acordo com a necessidade do educando e da realidade vivida por ele. 
Algumas escolas ou docentes ainda trabalham com uma "pedagogia tradicional", que é centrada na figura do docente, tendo por função ensinar e corrigir a matéria dada. Existe apenas uma transmissão de conteúdos por meio do docente que, geralmente, possui uma seqüência pré-determinada que acompanha um livro didático e/ou material produzido pela instituição de ensino, enfatizando a repetição de exercícios e, em alguns casos, a memorização de listas de palavras, valorizando, assim, o conteúdo e a quantidade. Nesse procedimento, o docente fala muito mais (TTT elevado) que seu sujeito-aluno, sendo que este apenas ouve e limita-se a responder aos exercícios; não existe uma interação entre docente e discente, um diálogo para a construção de um saber. $\mathrm{O}$ sujeito-aluno não tem uma participação ativa na construção de sua aprendizagem, e o docente não considera o outro, o seu histórico.

Para que uma aprendizagem se estabeleça, é preciso ocorrer uma verdadeira transferência de trabalho. Segundo Lacan (informação verbal) ${ }^{39}$, ensinar é gerar uma transferência de trabalho, portanto ensinar é colocar o sujeito-aluno para trabalhar, fazendo-o ir em busca do que ele não sabe; essa idéia é pautada num modelo de filosofia antiga do papel do mestre, o qual faz o seu educando trabalhar e ir em busca de seu próprio processo ou caminho. Nesse sentido, o educador deveria se perguntar, de tempos em tempos, se ele vem estabelecendo essa transferência com seu educando e se ele percebe o outro que está em sua aula, visto que "Ser é ser percebido", como diria Berkeley (informação verbal) ${ }^{40}$.

Notamos que o fazer persuasivo da mídia televisiva e de informes publicitários, como cartazes, banners ou folhetos, manipulam as informações por meio da sedução ou tentação, levando o sujeito-aluno a procurar uma escola de inglês. Não há, por parte do sujeito-aluno, uma

\footnotetext{
39 Anotação das aulas de Psicanálise e Educação Inclusiva, ministradas pela Profa. Dra. Leny M. Mrech na Faculdade de Educação da Universidade de São Paulo, em 2003. idem
} 
análise dos métodos dessa escola ou da formação de seus docentes. Desprovidos de uma avaliação mais apurada, esses indivíduos aceitam fazer parte do programa de ensino de línguas, assim, iniciam o curso e, com o tempo, vão se ausentando das aulas ou acabam se desmotivando e, conseqüentemente, desistindo do curso.

Nesse sentido, podemos dizer que, inicialmente, tudo parece ser muito bom, atraente, até mesmo, interessante e diferente. À medida que o tempo passa, a estrutura pela qual essas aulas foram submetidas não preenche as reais necessidades do sujeito-aluno ou o contrato que foi proposto pela escola não corresponde ao que foi prometido. Essas questões podem advir de um despreparo dos docentes ou, até mesmo, da forma que a metodologia pretendida é utilizada e não vai ao encontro das singularidades dos diferentes educandos. O que em princípio seria buscar um conhecimento da língua inglesa acabará levando o sujeito a experiências desastrosas e que deixarão seqüelas, distanciando-o cada vez mais do seu Ov, ou seja, da possibilidade de aprender a língua inglesa.

Não podemos deixar de salientar que, em muitos casos, a própria empresa delibera sobre a escolha de uma instituição de ensino para seus funcionários; o que significaria um bom negócio tanto para a escola quanto para a companhia devido aos pacotes promocionais de alguns programas de ensino e de um discurso bem elaborado sobre as vantagens que o curso trará aos funcionários daquela empresa. Dessa forma, o futuro discente estará sujeito ao /querer/ da companhia, que disponibilizará, uma verba parcial ou total, para o curso de inglês, desde que o funcionário aceite estudar na escola escolhida pela empresa. Todavia, se o educador conseguir transformar o /dever/ em /querer/, notaremos no educando uma melhora no desempenho lingüístico e aprender a L2 poderá se tornar prazeroso 
As atitudes corporais são outro elemento que deve ser observado numa relação de ensino-aprendizagem. Aprender a construir uma atenção ao que o educando enuncia, por meio do discurso oral ou escrito, é uma tarefa ordinária para um educador, visto que ele sempre exercitou sua atenção para perceber as deficiências de seu educando ou para saber se ele está melhorando. Contudo, o aspecto não verbal é um texto que passa despercebido para alguns docentes.

Esse texto sem palavras constrói um significado, pois são gestos inconscientes do educando e estão relacionados ao seu íntimo. O corpo traduz algo interno quando o educando cruza ou descruza os braços, balança as pernas sem parar ou posiciona seu corpo na direção da porta da sala de aula ou enruga o espaço entre as sobrancelhas, ou seja, são morfemas cinéticos que significam e o educador deve estar atento a esses pormenores, pois pode ser um sinal de como está o ritmo de uma aula ou da explicação do docente. Diante disso, observando o educando por meio de seu comportamento corporal, talvez o educador tenha de dar uma outra atividade para o educando, explicar outra vez ou, então, seria melhor interromper a aula e saber se está acontecendo algo com o educando. Essa linguagem não verbal expressa os pensamentos do sujeito-aluno, suas emoções e reações ao discurso pedagógico ou ao espaço em que ele se encontra.

Pais (informação verbal) ${ }^{41}$ diz que "uma aula é um espetáculo semiótico". De fato, quando entramos em uma sala de aula nos deparamos com uma série de informações que são captadas pelos sentidos, desde a disposição das cadeiras no espaço, até mesmo a maneira pela qual o educador se comporta corporalmente (posturas, feições) ou a maneira que o educador se coloca no espaço em relação ao seu educando. O espaço

$41 \quad$ Anotação das aulas de Análise Semiótica do Discurso Publicitário, ministradas pelo Prof. Dr. Cidmar Teodoro Pais na Escola de Comunicações e Artes da Universidade de São Paulo, em 2002. 
em que a aula de inglês é ministrada não será necessariamente o da instituição de ensino, poderá ser uma sala na própria companhia (incompany class), na qual o indivíduo trabalha.

Entretanto, na escola de idiomas, o educando tem acesso a todo um aparato tecnológico, diferentemente da empresa, pois nem sempre ela disponibilizará ou autorizará o uso dos mesmos aparatos. Diante disso, o educador precisará se valer de outros meios ou acordos firmados com seus educandos, com a escola ou com a própria companhia para a utilização desses meios. De qualquer forma será importante que o educador não se limite às condições de um espaço, sobretudo quando esse não puder dispor de materiais que são necessários para 0 aprimoramento da aprendizagem do educando.

O ator principal desse "espetáculo semiótico" parece estar centrado na figura do professor-educador, segundo o ponto de vista do educando, pois a transmissão da língua inglesa está vinculada ao papel do educador nesse processo. Não podemos negar que o educador é muito importante durante esse processo, sendo coadjuvante nessa relação que se estabelece entre a língua e o educando, pois auxilia o sujeito-aluno a construir uma saber lingüístico, viabilizando e gerando um conhecimento para ele e com ele. Contudo, o educando deve ter uma participação bastante ativa, sendo tão importante quanto o educador nesse processo. Não podemos esquecer que, por mais que o educador se esforce em gerar um conhecimento no seu educando, esse precisará fazer sua parte, visto que toda relação com o saber é uma relação com o outro e consigo mesmo; segundo o ponto de vista psicanalítico, a demanda é sempre do outro, isto é, daquele que busca um Ov.

Além de pensarmos no espaço físico e nos aspectos idiossincráticos do sujeito-aluno, devemos considerar também o aspecto temporal: tempo interno vs tempo externo. O educando está em uma constante pressão do 
fator tempo com relação à aprendizagem da L2; esse educando encontrase em uma situação difícil, pois fazer parte do mercado ou conquistar um cargo melhor na companhia em que trabalha, significa ter um nível fluente da língua inglesa.

Todavia, aprender um idioma demanda tempo e disponibilidade para tal. O outro aspecto é o 'tempo interno' de aprendizagem do sujeito-aluno, ou seja, o estabelecimento de uma 'maturação cognitiva' da L2, que difere de indivíduo para indivíduo, podendo ser mais rápido ou não, dependendo dos objetivos do educando e de suas expectativas com relação ao seu Ov; para tanto, ele precisará se mobilizar e "criar" uma disponibilidade para estudar, já que geralmente esse indivíduo adulto não dispõe de muito tempo.

\subsection{Transmissão de um saber: mediação e motivação}

Embora já tenhamos comentado, nos limites desta pesquisa, sobre elementos mediadores na transmissão da L2, gostaríamos de discorrer com maior profundidade sobre a importância da mediação de um saber lingüístico no processo de ensino-aprendizagem.

Ensinar é comunicar algo a alguém, tornando um signo antes desconhecido ou parcialmente desconhecido factível, sabido pelo outro, pois torna-o cognoscível. Mas, para que essa comunicação se estabeleça, o enunciatário de uma mensagem precisa compreender os signos da linguagem em questão, decodificando-os de alguma forma. Conseqüentemente, necessitará de algo que possa servir de mediador para a nova linguagem. Peirce diria que "todo o signo pode ser traduzido em outro signo mais explícito" (SANTAELLA, 2002). Sob essa óptica, é que o trabalho do verdadeiro educador "toma forma", algo que estava amorfo ou sem sentido passa a ter sentido para o outro que escuta, é a maneira de 
se transmitir que fará toda a diferença na formação de um indivíduo. Bourdieu (1998, p. 61) faz a seguinte consideração a esse respeito:

\begin{abstract}
Sabe-se, com efeito, para usar a linguagem da teoria da comunicação, que a recepção adequada de uma mensagem supõe uma adequação entre as aptidões do receptor (aquilo que chamamos grosseiramente de sua cultura) e a natureza mais ou menos original, mais ou menos redundante, da mensagem. Essa adequação pode, evidentemente, realizar-se em todos os níveis, mas é igualmente evidente que o conteúdo informativo e estético da mensagem efetivamente recebida tem tanto mais chances de ser mais pobre, quanto a "cultura" do receptor for ela própria mais pobre.
\end{abstract}

Diante disso, o educador precisa fazer adequações em suas explicações quando necessário, para auxiliar na compreensão da L2 em alguns momentos do processo de aprendizagem do educando; assim sendo, o educador utiliza de uma linguagem mais acessível ao universo do educando e, posteriormente, ele irá acrescentar mais conteúdo informativo acerca de um saber lingüístico para que haja um crescimento qualitativo e quantitativo de informações relacionadas a esse saber

O educador deve deixar claro para o educando o que ele pretende ensinar durante o curso, ou seja, os objetivos que serão trabalhados com ele, considerando a entrevista inicial e a avaliação lingüística realizada naquele momento, mostrando na prática o uso funcional daquele saber, pensando em aulas mais dinâmicas e criativas para conseguir prender a atenção de seu educando. Dessa maneira, tornaria o indivíduo mais engajado nas diferentes atividades propostas pelo educador. Se o educador quiser avaliar com maior propriedade a maneira pela qual o indivíduo aprende, deverá colocá-lo em situações bem diversificadas (usos de técnicas e métodos) para que possa estudar o seu desenvolvimento e levantar as dificuldades e facilidades do sujeito-aluno. Ao mesmo tempo, o 
educador estaria propiciando ao educando o desenvolvimento de outras habilidades cognitivas que, até então, não tinham sido usadas ou estavam adormecidas.

Nesse sentido, a utilização de materiais diversos como "auxiliares externos" na aprendizagem proverá o educando de caminhos alternativos para trabalhar com o saber lingüístico; é uma maneira de o educador mediar a compreensão cognitiva do sujeito-aluno sem ser algo extremamente controlado, pois o educador poderá inibir a criatividade do educando ou restringi-la; o educador mediando suas explicações por meio de algo que faça parte do universo sócio-lingüístico-cultural do sujeitoaluno, com atividades sensoriais diversificadas e criativas, levará esse sujeito a uma internalização eficaz dos elementos lingüísticos da L2, contanto que essas atividades estejam sempre contextualizadas ao que o educador estiver ensinando naquele momento, como já havíamos comentado. Sendo assim, o educador deve ter em mente a questão do código, no momento em que estiver transmitindo um novo conhecimento, visto que esse novo código está ainda sendo estruturado pelo educando.

A interpretação de um signo lingüístico, por meio de outros signos da mesma língua, é uma operação metalingüística que irá desempenhar um papel essencial na aprendizagem. Esse recurso da metalinguagem é necessário durante o processo de ensino-aprendizagem. No caso da L2, o educando está aprendendo um novo código lingüístico, por isso, os 'elementos correlatos' serão um meio para amparar um discurso verbal, assim, por meio de outros textos verbais, não verbais ou sincréticos poderemos fazer com que o educando construa um código estrangeiro.

Não obstante, a maneira que o educador executa um discurso metalingüístico poderá acarretar um entendimento maior ou menor do educando. Muitas vezes, um discurso muito técnico acaba provocando 
mais dúvida no educando, ocorrendo, assim, um maior distanciamento da L2 e, conseqüentemente, a desmotivação do sujeito. O objetivo é fazer o educando se aproximar do seu Ov, fazendo que ele se aproprie da nova língua. Mediante o método e a técnica que o educador estiver utilizando, a L2 começará a se estruturar paulatinamente. Com o passar do tempo, o próprio sujeito-aluno poderá construir e tecer sua rede de significações, procurando outras fontes que possam lhe ajudar a ampliar seus conhecimentos.

A memória de um indivíduo cognitivamente mais amadurecido está carregada de lógica, de pensamentos abstratos muito mais complexos, em que os conceitos já foram formados e estão prontos para receber informações cada vez mais complexas. Antes, pensar para as crianças significava lembrar, no entanto, após essa fase, para o adolescente ou adulto lembrar significa pensar. Agora, esse indivíduo precisa estabelecer relações lógicas para que façam parte de sua memória, assim, devem ser reconhecidas, decodificadas e, portanto, internalizadas. Nesse último caso, cria-se um elo temporário por meio da combinação de estímulos externos.

Vejamos algumas técnicas que utilizamos para mediar as explicações na $\mathrm{L} 2$, levando o educando a construir um sentido de um outro universo lingüístico:

1- Imagens: material icônico que representam ações. Quanto maior for a iconicidade representada pelo material utilizado, maior será a acuidade na transposição do sentido. Esse material auxilia 0 educando numa memorização da ação.

2- Vivência, role playing e mímica: Todos esses elementos são eficazes para podermos expressar o sentido de um determinado vocábulo, expressões ou situações de um contexto, levando o sujeito-aluno a 
fazer uma imagem mental do que estamos ensinando. A conceptualização de uma situação ou vocábulo torna-se muito mais fácil e rápida quando colocada em contexto real e simulado (encenação de uma situação ou o ato mimético de algo que se queira transmitir ao educando). A linguagem verbal, aliada à imagem visual (relação de complementaridade), auxilia o educando a compreender mais facilmente o que o educador quer transmitir.

3- Metalinguagem: a utilização de uma metalinguagem é necessária, à medida que o discurso pedagógico precisa deixar claro o que quer transmitir ao educando.

4- Material: o material pode ser desde documentos reais (realia) que o sujeito-aluno utiliza em seu trabalho ou possa vir a precisar como também, qualquer material de leitura que possa levar mais informações ao indivíduo, amplificando seu vocabulário e o campo semântico das palavras em contextos diferentes. Além do material escrito, devemos sempre utilizar dos materiais audiovisuais, CDs-rom, músicas, filmes, jogos que ajudam a construir uma significação da L2.

Seja qual for o recurso utilizado para demonstrar o sentido de uma frase ou uma unidade léxica, o educador precisa sempre relacionar às situações aprendidas, anteriormente, levando o sujeito-aluno a refletir sobre o que ele está lendo, sobretudo chamando a atenção do educando sobre alguns elementos constitutivos da frase, como por exemplo, uma preposição, phrasal verbs, o uso de um determinado verbo ou vocábulo, que podem ter outras funções e sentidos diferentes dentro da frase: 


\begin{tabular}{|l|l|}
\hline I sold a book (livro) & I'll book a table for us (reservar) \\
\hline $\begin{array}{l}\text { We are all booked up for Friday } \\
\text { night (estar tudo reservado, lotado) }\end{array}$ & $\begin{array}{l}\text { I forgot to call you up yesterday } \\
\text { (telefonar) }\end{array}$ \\
\hline $\begin{array}{l}\text { Can you wait while I make another } \\
\text { call ? (fazer uma chamada } \\
\text { telefônica) }\end{array}$ & $\begin{array}{l}\text { Last night several friends called on } \\
\text { us (visitar) }\end{array}$ \\
\hline
\end{tabular}

Assim, a ênfase sobre alguns aspectos lingüísticos da língua inglesa, já estudados pelo educando ou explicações de algo que possa vir a ser um problema para o educando na $\mathrm{L} 2$, devem ser sempre relembrados e retomados. Essa ação do educador é importante no processo de ensinoaprendizagem, pois o educando acabará memorizando essas situações e, naturalmente, as reproduzirá, respondendo prontamente quando lhe for requisitado. Convém lembrar que precisamos ter um suporte (uma informação pressuposta e conhecida pelo receptor) e aportes (informações suplementares) em estrutura profunda para que se estabeleça um diálogo, uma troca de informações, assim, o educando poderá decodificar o que é comunicado. O ato de comunicação necessita de um suporte e de um aporte se o educando não tiver uma informação prévia, a aprendizagem não é instaurada.

Sendo assim, o educador apenas poderá avaliar se o seu discurso pedagógico foi efetivado ou não por meio da produção escrita ou oral do educando (plano de expressão), pois o educador será capaz de observar a maneira que o educando interpreta, decodifica o que foi transmitido, assim, mensurar a aprendizagem do sujeito-aluno e a forma que vem construindo uma rede de relações da L2. Após a avaliação, o educador poderá examinar e analisar se o material proposto por ele, construiu uma resposta positiva no sujeito-aluno. 
Com base naquelas tarefas, o educador pensa em um plano metodológico adequado às necessidades específicas do indivíduo naquele momento. Apesar de ter sido estabelecido um plano metodológico geral no início do curso, o educador reelabora outras abordagens metodológicas no desenvolvimento do processo de ensino-aprendizagem. Esse plano metodológico é constantemente revisitado, pois o sujeito-aluno vai melhorando seu desempenho lingüístico e, assim, as necessidades vão se transformando, também.

Daí a necessidade de o educador sempre estar atento à maneira pela qual seu educando tece considerações acerca do novo, o modo que ele constrói esse saber nas várias etapas que se seguem aos diferentes estímulos dados para a internalização da nova língua. Assim, as aulas mais dinâmicas acabam motivando o educando, sempre considerando o perfil do educando, seu desenvolvimento lingüístico, suas dificuldades.

O fato de um novo universo lingüístico estar sendo conceptualizado implica sempre a realimentação e auto-regulagem do sistema, que será mantido por meio de atividades práticas como a leitura, exercícios escritos e orais, listenings, dentre outras. Aos poucos, o conhecimento vai sendo agregado a outros dentro do novo sistema e novas (re)alimentações e atualizações são feitas. Além disso, o educador deve propor atividades fora do ambiente de sala de aula, pois são motivadoras para o educando e despertam o interesse dele. Esses encontros são em lugares distintos, como pubs, museus, teatro, pinacoteca, exposições, filmes, peças teatrais em inglês, etc.; além de o educando ser colocado em situações reais, os aspectos do capital cultural também são trabalhados. Um ambiente com uma atmosfera convidativa e divertida, seja durante a aula ou nesses encontros, traz o educando mais próximo de um /querer-aprender/, pois possibilitamos meios para que o sujeito-aluno se sinta bem e à vontade. 
Logo, se o educador conseguir construir uma atmosfera mais descontraída com a aprendizagem da L2, tanto melhor para o desempenho do educando.

Como já comentamos, a diversidade de materiais auxiliam no aprimoramento da produção oral ou escrita, ocorrendo uma otimização do sistema, do saber lingüístico de maneira ampla. Contudo, a explicação do educador precisa estar respaldada num discurso pedagógico adequado às limitações de seu sujeito-aluno. Se a idéia de algo que se quer explicar for eficaz, o discurso pedagógico acabará construindo um saber e motivando o educando a um fazer interpretativo cada vez mais apurado e, assim, o educando conseguirá reter melhor, no seu banco de memórias, as informações aprendidas. As significações que se manifestam no ato do discurso escrito ou oral são interpretações do que foi conceptualizado internamente, por intermédio de textos verbais, não verbais ou sincréticos.

A interpretação do sujeito-aluno ou o ato semiótico só poderá efetivarse quando houver um saber morfológico, sintático, semântico, fonológico e lexical da língua inglesa, que vão sendo internalizados pelo sujeito-aluno à medida que ele estuda a L2. Quando essas regras se encontram atualizadas no universo lingüístico do sujeito-aluno, ele prontamente distingue o código, decodificando o que é enviado por meio da fala ou da escrita, portanto ele já simboliza em sua mente aquilo que uma palavra ou um grupo de palavras significa.

A "qualidade" do que é transmitido ao educando é muito mais importante do que a "quantidade" de informações da L2. Nesse sentido, partimos, inicialmente, de uma boa qualidade de semióticas-objeto que signifiquem ao educando, que possa ser construído um percurso de sentido mais agradável e eficaz. Com o passar do tempo, agregamos mais conteúdo lingüístico ao educando. 
Diante desse quadro, percebemos que a mente que estuda a L2 depende de uma mediação para entender, semiotizar o seu objeto de estudo. $\mathrm{O}$ educando aprende melhor quando estabelece relações entre as coisas no mundo e o que elas significam. Quando o educando está aprendendo a L2, ele irá precisar daqueles 'elementos correlatos' para utilizá-los como liame na construção da $L 2$, servindo de apoio para o banco de dados de sua memória. Esses 'elementos correlatos' acabam por sugerir ou evocar palavras, situações, sentimentos que nos remetem à língua mãe (L1) e são transportadas à L2. Uma memória mediada por esses elementos é muito mais poderosa do que a memória não mediada, o desempenho cognitivo e lingüístico é enriquecido. Esses 'elementos correlatos' são estímulos externos que amparam a constituição de um novo saber, sendo relevantes para o processo de ensino-aprendizagem de uma língua natural. Quanto mais estímulo tiver o cérebro, maior será a capacidade de memorização do sujeito-aluno.

Parte do sucesso do ensino de línguas deve-se ao fato do educador sempre motivar o educando, mostrando-lhe diferentes formas de se estudar e dando sugestões para alguns problemas encontrados. Além disso, é necessário que o educador elogie o bom desempenho do educando durante o processo, reforçando positivamente a ação do educando quando esse procura estudar mais ou fazer as lições. Diante disso, o educador deve estar sempre atento às dificuldades de seu educando e às necessidades imediatas, estudando uma maneira mais apropriada para transmitir a L2, fazendo, ao mesmo tempo, que ele encontre um método particular de estudo, propiciando condições para que ele crie uma autonomia, já que cedo ou tarde, esse sujeito-aluno precisará estar apto para resolver questões de ordem lingüística por si mesmo. 
Para que uma motivação ocorra, o educador precisa pensar na forma que o sujeito-aluno aprende. Para tanto, o educador leva em consideração as 7 inteligências apontadas por Howard Gardener $^{42}$ que irão ajudar no processo de aprendizagem do sujeito. Cada indivíduo utiliza de uma inteligência ou mais de uma. Existem discentes que usam a inteligência física e, dessa maneira, aprendem melhor com jogos, exercícios, movendose pela sala de aula; outros aprendem melhor com a inteligência visual, esses adoram assistir a vídeos, ver fotos ou diagramas, etc. Quando o educador se preocupa com o tipo de inteligência apresentada pelo educando, este se torna mais engajado e acaba por se dedicar mais. Mesmo sabendo que existe uma inteligência que prevalece, o educador deve tentar utilizar outras inteligências para ampliar a capacidade intelectual do educando, visto que a aprendizagem será otimizada quando as diferentes inteligências forem utilizadas.

\subsection{Transmissão e aquisição de um saber numa língua estrangeira}

A faixa etária de aquisição de uma língua estrangeira ocorre de maneira mais otimizada até 10 anos, após essa idade, a aquisição não acontecerá da mesma forma. Diante desse fato, o educador terá de lidar de uma outra maneira com essa questão da aquisição da L2 para adultos, considerando as vivências do educando e a maneira que ele aprende, além do uso de técnicas variadas para aperfeiçoar a aprendizagem do educando. O grande empecilho, nesse processo de ensino-aprendizagem, são as barreiras colocadas pelo educando durante esse processo. O adulto

42

De acordo com Howard Gardener (1998 apud LOWES.R. e TARGET.F., p.29-30), os discentes têm inteligências diferentes, uma vez que a motivação varia de sujeito para sujeito, portanto, essas inteligências devem ser consideradas pelo educador para conseguir um aproveitamento melhor do educando, durante seu aprendizado da L2. Há sete tipos de inteligências, a saber: Physical intelligence; Linguistic intelligence; Mathematical/Logical intelligence; Visual/spatial intelligence; Musical intelligence; Interpersonal intelligence; e Intra-personal intelligence. 
sempre racionaliza os erros cometidos durante a expressão oral ou escrita, não querendo ou podendo encarar sua própria realidade. Além disso, com o tempo, o sujeito adulto torna-se mais resistente, automatizado pela cotidianidade, fechando suas percepções, conseqüentemente, um olhar para o novo. Para construir, é preciso desconstruir o velho, agregando informações sendo sujeito de sua ação e sendo sujeitado por ela, também.

Ter um bom conhecimento da língua inglesa não significa poder ensiná-la, além de saber o idioma, o docente precisa ser capaz de transmitir e gerar uma competência no outro. Ser educador demanda responsabilidade com o que se está transmitindo, sobretudo a maneira que transmitimos algo a alguém. A comunicação é a base de qualquer aprendizado, em especial, uma língua natural. O docente, que já é uma pessoa competente na língua estrangeira, busca meios para transmitir o saber lingüístico, levando o educando a decodificar um código lingüístico novo e codificar o mesmo código. A relação entre educador e educando poderá estreitar-se à medida que o educando avança em seu percurso. Tomemos a teoria dos conjuntos para ilustrar : 

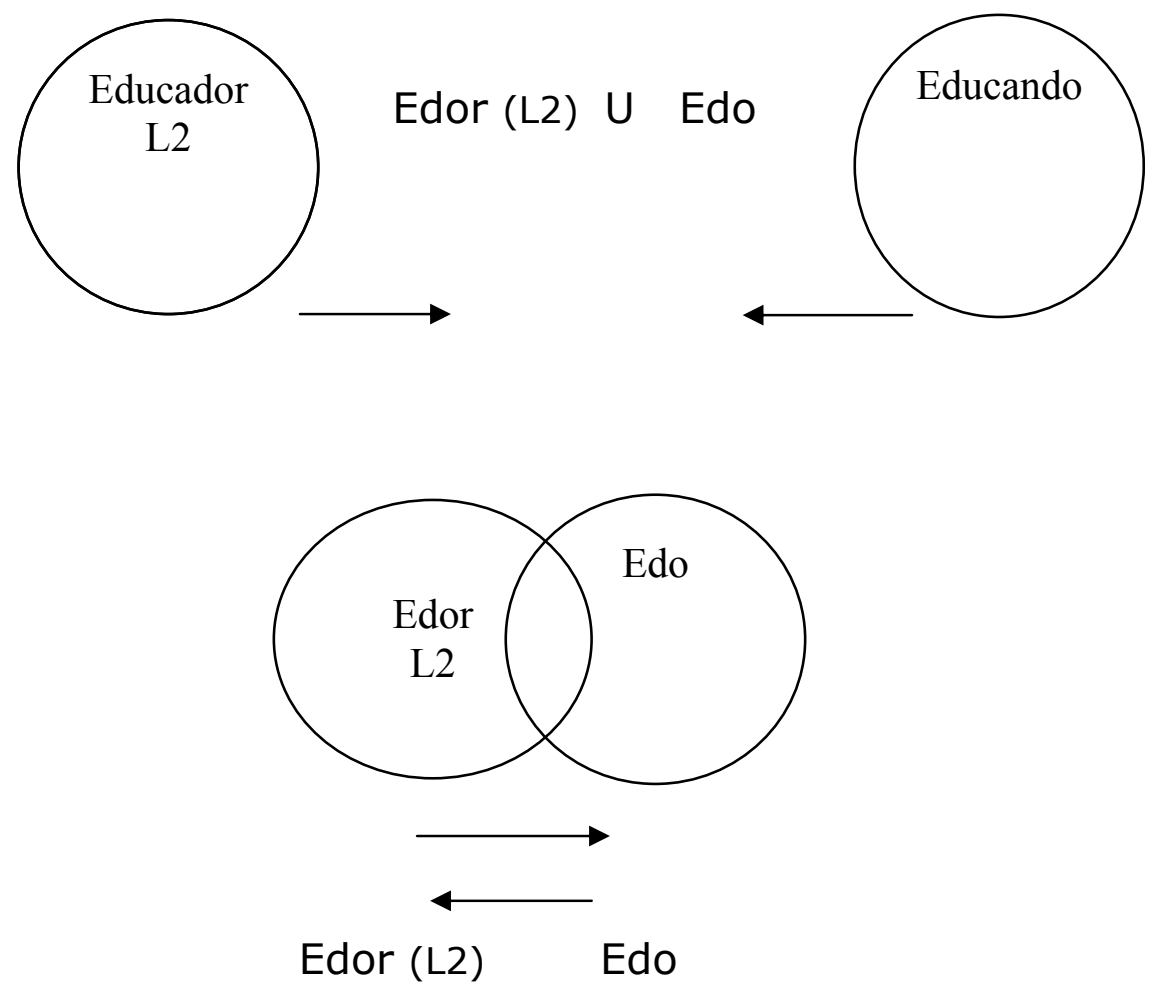

Onde: Edor $=$ educador

$$
\begin{aligned}
\text { Edo } & =\text { educando } \\
U & =\text { disjunção } \\
\cap & =\text { conjunção } \\
\mathrm{OV} & =\text { objeto de valor }(=\mathrm{L} 2) \\
\mathrm{L} 2 & =\text { Língua Inglesa }
\end{aligned}
$$

Figura 9: Teoria dos conjuntos: educador e educando

O docente poderá optar por uma forma cartesiana no ensino de línguas ou tentar experimentar situações novas, tornando o conhecimento mais produtivo, rico e interessante para o educando. Não devemos esquecer que o sujeito-aluno busca algo que seja diferente das metodologias trabalhadas em sala de aula e que, muitas vezes, a desistência ou a resistência às aulas de inglês teve origem justamente no ensino mais antiquado e na relação que o docente manteve com o sujeito-aluno. Diante 
disso, parece-nos relevante pensar em situações que possam fazer o educando vivenciar de forma diferente um saber lingüístico, partindo do seu universo e amplificando outras formas de envolvimento com o objeto de estudo, levando-o à uma produção mais significativa e a um olhar mais abrangente sobre a língua inglesa.

Nessa perspectiva, o professor-educador propõe um percurso que seja mais interativo, criativo e instigante (recursos audiovisuais, mídias e outras tecnologias como a internet, vídeo, TV, rádio, DVD), que o leve a /quererl construir seu saber. Assim, queremos que o sujeito-aluno descubra o prazer em se instruir, que apesar de um dia estafante de trabalho, ele sinta-se bem e motivado para estudar, participar das atividades propostas na sala de aula, encontrando em suas aulas ou mesmo nas horas vagas uma disposição para estudar e trabalhar em seu próprio processo de conhecimento, podendo utilizar esse saber como uma ferramenta para intervir no mundo da maneira que precisar. Quando as coisas passam a significar para o educando, ele aprende bem mais depressa, sobretudo quando se sente mais motivado e tem um objetivo em vista.

Todos os métodos e técnicas empreendidos pelo educador levarão o educando a construir um arcabouço lingüístico e um domínio maior da língua inglesa, a qual será, gradualmente, amplificada pela qualidade do ensino e planejamento das necessidades do educando.

O desempenho apenas poderá ser mensurado por meio do desenvolvimento da expressão escrita e falada do sujeito cognitivo. O educando, com o tempo, irá codificar e decodificar enunciados cada vez mais complexos, dando forma a algo que estava amorfo ou era inexistente, dependendo da relação entre o sujeito-aluno e a língua estudada (percurso do aluno-educando) e a maneira que o educador irá trabalhar com seu educando essa língua (percurso do professor-educador). 
Quando trabalhamos a expressão oral, precisamos fazer com que o educando reconheça os sons da fala de L2. Dessa forma, estudamos com ele o inventário de fonemas da língua inglesa, sobretudo, os fonemas que ele apresenta mais dificuldade, como por exemplo: $/ \partial /, / \theta /$ e $/ t /$ (diferentes sons do t) ou as diferenças entre o /i:/ e o /i/ que para o falante de língua portuguesa são difíceis, pois esses fonemas não fazem parte de nosso inventário de sons. Em princípio, teremos um educando com dificuldades para pronunciar algumas palavras, assim sendo, os sons dessas palavras serão interpretados com uma certa acomodação ao sistema do seu próprio idioma, nesse caso a língua portuguesa. Palomo (1971, apud Gili Gaya, p. 84), em sua Tese de doutorado, cita Gili Gaya que diz:

Não se trata de uma dificuldade de audição, mas da ausência no sistema materno de um fonema ao qual referir o som que ouve. Por isso, na aprendizagem de línguas vivas não se consegue reproduzir com exatidão as articulações, até que se tenha formado a imagem mental dos fonemas novos.

Palomo (1989, p. 296) acrescenta:

As diferenças ativam o mecanismo de interferência nas condições de contacto e este mecanismo se torna responsável por várias dificuldades que, por sua vez, interferem diferenciadamente sobre 0 processo de comunicação. ( $O$ estudo das línguas estrangeiras se faz sobre o fundo de um código anteriormente assimilado e que funciona já há algum tempo, pelo menos)" .

(...) conseqüentemente, é para a acentuada importância de mecanismos de interferência que se deve atentar no processo de ensino/aprendizagem, a fim de definir a natureza e o alcance das distorções e inibições). 
Nesse sentido, o educador deve apontar para o educando os traços distintivos e pertinentes, pois serão esses traços que o educando irá emitir e reconhecer quando em uma situação comunicativa; além disso, é importante que o educando aprenda a relacionar os signos gráficos ou letras ao sistema fonológico da L2, que são distintos entre si. Por exemplo, o i longo (i:) é grafado de formas variadas: seed /si:d/; sea /si:/; Be /bi:/; key /ki:/, receive /ri'si:v/; Sydney /sidni:/, etc. A respeito do sistema fonológico e alfabético Biderman (1978, p. 48-9) diz o seguinte:

\begin{abstract}
Para que um sistema gráfico fosse ideal, seria necessário que a cada fonema correspondesse um a um só grafema e, inversamente, que a cada grafema correspondesse um único fonema. Via de regra, porém, não há equivalência entre o sistema fonológico e o sistema alfabético. Com freqüência o número de signos gráficos - letras - é menor que o número de fonemas das línguas. De fato, as línguas ocidentais que adotaram o alfabeto latino utilizaram sempre os 26 símbolos tradicionais para transcrever o seu sistema fonológico que comportava um número maior de unidades fonêmicas.

Assim 0 inglês utiliza 26 caracteres gráficos para representar os seus 46 fonemas, com uma carência, portanto, de 20 símbolos; o português emprega 24 letras para simbolizar os seus 33 fonemas, com um déficit, pois, de 9 signos. Daí resulta que há uso duplo ou triplo dos mesmos símbolos e a manipulação de artifícios gráficos geralmente insatisfatórios e pouco econômicos.
\end{abstract}

Diante disso, é importante que o educador discuta com seu educando a diferença entre segmentos fônicos e segmentos gráficos que são bem diferentes no inglês, conscientizando-o de que o código falado em inglês é diferente do escrito; sendo assim, quanto mais exercícios de leitura, de listening ou de ditados, mais fácil será a aquisição do sistema fonológico/discriminação auditiva, juntamente com a expressão escrita. Para tanto, o educando também poderá utilizar-se de outra técnica, a transliteração dos sons, ou seja, o educando transcreve a seqüência fônica da palavra em inglês nos símbolos gráficos do português, como se 
estivesse lendo em seu próprio idioma (integração dos segmentos fônicos com os gráficos)

Com o tempo, é ensinado ao educando a transcrição fonética dos sons da língua inglesa (os símbolos convencionados ou o que chamamos de alfabeto fonético internacional), pois os dicionários trazem essa transcrição e o educando precisa saber utilizar essa ferramenta para que ele tenha uma maior autonomia quando houver alguma palavra que ele não saiba pronunciar.

O educando só perderá o filtro fonológico com a práxis; algumas vezes, a articulação da palavra ainda não está clara, prejudicando a discriminação auditiva do ouvinte devido às diferenças fonológicas da L1 com relação à L2 e que leva o educando a uma proximidade articulatória dos fonemas da L2 como já comentamos. Sabemos que a pronúncia errônea interfere na comunicação causando ruídos. Dessa forma, quanto mais consciente o educando for dos mecanismos articulatórios, melhor será sua discriminação auditiva. Se existe uma falha na percepção auditiva, conseqüentemente, haverá falha na articulação. Palomo (1989: 291) comenta o seguinte sobre a discriminação auditiva:

Sabemos perfeitamente que antes de falar corretamente, o sujeito precisa ouvir corretamente. Mesmo em língua materna, muitas falhas de articulação fonética se devem a falhas de discriminação auditiva.

Durante as aulas, o educador deve ter conhecimento dos problemas encontrados pelo educando para articular um determinado fonema, isto é, ele deve estar ciente das interferências da língua materna na L2 e da dificuldade em articular alguns sons. A partir desse levantamento das dificuldades, o educador poderá desenvolver um plano de aula para otimizar o desempenho verbal do educando. Quanto mais familiaridade o educando tiver com sons da L2 por meio de role plays, listenings, 
exercícios orais, dentre outros, melhor será seu desempenho na discriminação auditiva e conseqüente melhora na articulação vocal.

Quando o educando comete um "erro" na expressão escrita ou oral, temos de levá-lo a entender primeiramente o que errou e depois mostrarIhe o tipo de ruído que pode ocorrer na comunicação, dando-lhe exemplos. Em nível fonológico, temos as diferenças de vogais breves e longas, por exemplo /i/ (i curto) e /i:/ (i longo) como em ship e sheep; seat e sit ou a diferença entre os sons do ch /t $\int /$ e sh / $\int /$ como em chips e ships; wash e watch ou que, articuladas de outra forma, provocam a mudança de significado, ou seja, em vez de dizer write /rait/ ele diria white /wait/ ou dizer think /eink/ diria sink /sink/, dentre outros.

Por ser a grafia da língua inglesa distinta de seus sons, o educando, normalmente, comete alguns erros na expressão escrita. Segundo Biderman (1978, p. 49-50), essa dissonância com relação aos fonemas e a grafia deve-se a três causas básicas:

$1^{\text {a) }}$ na origem, o sistema gráfico já não representava satisfatoriamente o código oral; $2^{\mathrm{a}}$ ) a língua continuou a evoluir e o sistema ortográfico foi mantido estático, por causa da força de inércia da tradição; $3^{a}$ ) o prestígio do grego e do latim na renascença veio acrescentar a esse sistema já imperfeito, uma multidão de grafias anômalas, motivadas por razões etimológicas (às vezes falsas etimologias)."

Para que o educando possa exercitar essas diferenças, o livro Sheep or Ship (2002) demonstra, exemplifica e explica essas diferenças distintivas entre os sons e letras da língua inglesa por meio de diálogos divertidos e confrontação entre sons parecidos. 
A aquisição de uma língua estrangeira deve ser vista tanto sob o ponto de vista de regras quanto de usos e costumes de um povo. Pelo ponto de vista de regras, mostramos ao educando as normas existentes naquela língua, a que ela está ancorada. Do ponto de vista de usos e costumes, o sujeito-aluno não pode ser considerado um "falante ingênuo" ${ }^{43}$, visto que haverá ruídos na comunicação. O "falante ingênuo" desconhece as convenções estruturais de uma língua, as imagens metafóricas da L2, as frases idiomáticas e convencionais da língua, ou seja, desconhece os usos que fazem parte do sistema daquela língua e do dia-a-dia.

Devemos sempre ter em mente que, quando ensinamos um idioma, estamos, sobretudo, ensinando uma ideologia, valores e crenças de um povo. Cada cultura tem sua forma peculiar de expressar-se, suas convenções lingüísticas são parte do sistema da língua e o educador precisa considerar essas convenções da L2 se quiser gerar um conhecimento da língua que não seja superficial, levando o educando a uma percepção mais acurada de formas que, gramaticalmente, podem ser corretas, mas não é a maneira correta de expressar na L2. Por exemplo, a expressão It's a piece of cake (é moleza) será interpretada de maneira literal pelo educando, a menos que ele esteja falando de uma "fatia de bolo". Ou, então, mesmo que o educando conheça o sufixo -er (formador de substantivos) e algumas palavras como prison e jail, se ele desconhecer os lexemas idiomáticos da língua, não conseguirá distinguir um prisioner (prisioneiro) de um jailer (carcereiro) ${ }^{44}$

Assim sendo, o educador precisa e deve enfatizar a idiomaticidade e convencionalidade da L2, considerando os níveis (pragmático, semântico e

\footnotetext{
43 expressão utilizada por Charles Fillmore, citado por Tagnin (1989, p. 9)

44 exemplo extraído do livro de Tagnin (1989, p.10)
} 
sintático) e os diferentes graus de idiomaticidade (menos ou mais idiomáticos) da língua inglesa. Esse último levará o educando de língua inglesa a encontrar maior ou menor correspondência com as expressões idiomáticas da língua portuguesa. Por exemplo: To hold one's up (andar de cabeça erguida), provavelmente essa expressão é de fácil entendimento para o educando. Por outro lado, to speak one's mind (dizer o que pensa) tem sentido figurado e será mais difícil para ele compreender essa expressão. Todavia, é possível chegar ao significado de algumas expressões na L2 por dedução (se houver similaridades com a L1).

Posteriormente, o sujeito-aluno poderá encontrar relações com a expressão metafórica e o sentido que ela carrega (relação entre imagem e o sentido da expressão idiomática), mas precisará estar familiarizado com questões culturais ou com a imagem aludida. Há expressões que são totalmente idiomáticas (não-transparentes) e o educando não conseguirá fazer nenhuma relação de imagem com o sentido que elas carregam, pois o sentido é totalmente arbitrário. Sendo assim, as expressões idiomáticas dividem-se entre expressões metafóricas (relação entre significado e imagem aludida) e expressões idiomáticas propriamente ditas (têm sentido arbitrário, não se pode mais recuperar as relações dessa expressão, pois cristalizaram-se em algum ponto da história daquela cultura).

Nos livros didáticos de Business English é muito comum encontrarmos expressões relacionadas a uma situação específica do mundo dos negócios, que podem ser comentários cristalizados ou frases feitas (Speak of the devil... and he appears), expressões obrigatórias (Hi, How are you?) e expressões que sinalizam certas estratégias empregadas na conversação (gambitos), que segundo Tagnin (1989, p.52-55) ${ }^{45}$. Temos, então, os seguintes gambitos:

$45 \quad$ Segundo Tagnin, essas expressões fazem parte do nível pragmático da convencionalidade, ou seja, do nível da fala, dessa forma essas expressões estão 


\begin{tabular}{|l|l|}
\hline Estruturação Semântica & $\begin{array}{l}\text { But the problem is...; my guess is...; } \\
\text { speaking of...; Why don't you... }\end{array}$ \\
\hline Sinalização do Contexto Social & $\begin{array}{l}\text { May I interrupt you for a moment?; } \\
\text { Wait a second; That's about it; And } \\
\text { what about you? }\end{array}$ \\
\hline $\begin{array}{l}\text { Sinalização da Disposição de } \\
\text { Entendimento }\end{array}$ & $\begin{array}{l}\text { I'd like to hear about it; I'm not really } \\
\text { interested in that; I've got something } \\
\text { to tell you; I don't want to get into } \\
\text { that; I knew that; I don't know that) }\end{array}$ \\
\hline $\begin{array}{l}\text { Sinalização de Controle da } \\
\text { Comunicação }\end{array}$ & $\begin{array}{l}\text { Right?; Sure; Pardon me?; That's } \\
\text { not what I said }\end{array}$ \\
\hline \multicolumn{2}{|c|}{} \\
\hline
\end{tabular}

As expressões fixas ou fórmulas situacionais/ fórmulas fixas/ fórmulas de rotina são também muito comum no dia-a-dia ou num contexto de negócios, Would you mind...?; May I help you?; How about...?; Have fun; Hi...; Thanks...; Sorry; Cheers; Happy Birthday, até mesmo, as citações e provérbios. Assim, vamos agregando as expressões idiomáticas e convencionais da L2 durante o curso, conscientizando o educando desses usos ou costumes da língua estudada.

intimamente relacionadas a determinados comportamentos convencionados numa cultura. Nesse sentido, há situações que exigem um determinado comportamento que deve ser verbal (expressões obrigatórias), se não forem empregadas, poderão caracterizar um rompimento do comportamento social convencional. Em outras ocasiões, são usadas expressões que estão intimamente relacionadas a uma situação, mas são frases dispensáveis (frases feitas). 
O educador deve ter em mente que transmitir o saber de uma outra língua significa muito mais do que ensinar vocabulário, regras sintáticas, fonológicas e gramaticais. É evidente que devemos estar familiarizados com tudo isso para que possamos ordenar as idéias, as palavras em novos contextos e podermos expressar de forma clara nossos pensamentos. Contudo, ele deve pensar na maneira que lida com essa transmissão; por ser um código novo, o indivíduo precisará de um outro tipo de abordagem metodológica.

$\mathrm{Na}$ aquisição de uma língua estrangeira, precisamos de atividades mediadoras mais intensas, visto que vivemos em um país distinto da L2. O indivíduo na fase adulta já dispõe de mecanismos mais sofisticados de memorização e abstração, pois possui um amadurecimento de suas funções superiores, conseqüentemente, as fases principais e a base de desenvolvimento cognitivo já foram cumpridas; entretanto, o adulto educando precisa aprender a identificar, estruturar e saber como lidar com os novos signos lingüísticos tanto na expressão oral quanto escrita.

A faculdade da abstração tem um papel importantíssimo na comunicação e, conseqüentemente, na aprendizagem. Segundo J. Laporte (2002, apud OLIVEIRA, p.30) "só se abstrai o que se compara", sendo assim, poderemos colocar o educando em situações distintas de aprendizagem, comparando-as com o que ele está aprendendo, seja por meio de frases, de imagens, diálogos, etc. Dessa forma, o educando depreende um sentido sobre as coisas, agrupando, categorizando e classificando, portanto, passa a entender o conceito ou idéia de algo na língua inglesa.

Ensinar outro idioma para um indivíduo com a base lingüística estruturada, dentro de uma outra cultura, irá envolver mecanismos outros com relação à memorização e conseqüente internalização das funções 
psicológicas superiores do código desconhecido. Tendo uma base biologicamente preservada, amadurecida e estruturada quanto aos aspectos do desenvolvimento verbal e cognitivo, não há razão para a L2 não ser instaurada, mas devemos considerar o histórico desse indivíduo para que as aulas possam ser mais proveitosas para ele. Dessa forma, ele dota o educando de diferentes maneiras de estudar a língua, por isso seria importante que ele explicasse qual é o objetivo dos exercícios e métodos propostos por ele. Esses exercícios são ferramentas e/ou métodos que auxiliam na construção do repertório lingüístico do educando. Assim, as redes associativas que o educando irá tecer, com o passar do tempo, acabarão levando-o cada vez mais próximo de seu Ov.

Todavia, durante o processo, é necessário que o educador procure dar assistência, demonstrar, instruir, fornecer meios, usar diferentes metáforas comparadas ao objeto de estudo para facilitar a compreensão do educando. Esses tipos de intervenção feitas pelo educador são um processo pedagógico necessário na aquisição de língua. Só podemos inferir ou abstrair com base nos conhecimentos adquiridos previamente e que foram se depositando em nossas mentes por meio de experiências ricas e diversificadas. Diante desse quadro, o educando não verá mais o docente como aquele que é encarregado de passar somente regras gramaticais. Esse docente é um indivíduo mais acessível, com um 'olhar sensível' sobre a realidade do outro e sobre suas necessidades também; abriu-se uma possibilidade de diálogo sobre a língua, levando o educando a construir um saber mais amplo que resultará em um melhor desempenho na L2.

Aprender significa desenvolver-se cada vez mais e despertar outras áreas do cérebro que antes estavam adormecidas, ampliando a visão de mundo; é antes de tudo, estar aberto ao novo como ocorre com Kaspar 
Hauser $^{46}$ que, num primeiro momento, fica completamente apoplético, quando se depara com um outro mundo, muito além daquele sótão onde vivia, mas com o tempo, ele passa a vivenciar tudo que o cerca de maneira intensa, tentando conceituar um mundo distinto de seu referencial interno, justamente por ter sido privado de um ambiente social e de interações com outras pessoas.

Quando se estabelece uma visão mais ampla da língua, o educando constrói uma outra forma de comprometimento com a L2. Em princípio, ele tende a traduzir e querer achar significado para todas as palavras, sempre pensando em sua língua materna (transpondo uma língua para a outra). Contudo, quanto mais consciente do sistema lingüístico da L2 ele se torna, mais rapidamente ele abandona essas transposições indevidas e mais apto estará o educando nas suas produções discursivas. Algo que se encontrava amorfo começará a ganhar uma forma, conseqüentemente um conteúdo, passando a significar para o educando.

O processo de ensino de uma língua não é algo simples. Além de pensarmos nos aspectos lingüísticos, precisamos olhar para o outro. Esse outro é a nossa exata medida para se elaborar algo; com o tempo, ampliamos a capacidade desse educando de olhar o mundo, mostrando Ihe que sua interação com um saber lingüístico poderá abrir outras portas, especialmente quando quiser saber sobre outras áreas do conhecimento humano que estejam escritos na L2, deixando-o mais próximo não só de uma possibilidade de inserção no mercado de trabalho, já que o inglês é a língua internacional para interação, notadamente no âmbito dos negócios, mas também para se comunicar com outras culturas, podendo ter acesso a

$46 \quad$ "O enigma de Kaspar Hauser" - dirigido por Werner Herzog em 1974. Trata-se de uma pessoa chamada Kaspar Hauser que, logo após o nascimento, foi mantido escondido em um celeiro, privado de qualquer contato com o mundo externo até completar 18 anos. Quando é retirado, não sabe falar nem andar, sendo assim impossibilitado de articular raciocínios. 
uma educação especializada também, visto que um dos requisitos para obter uma formação em nível de pós-graduação é o conhecimento da língua inglesa.

As leituras possibilitam a ampliação do léxico, como comentamos anteriormente, além de uma compreensão maior da sintaxe e da morfologia, mas o educando precisa observar o léxico em contextos distintos para compreender a polissemia (extensão do sentido) de uma palavra e, conseqüentemente, diferentes isotopias nesses contextos. Captamos o valor da palavra pela situação, portanto, o educando precisa saber como as palavras adquirem sentidos diferentes (semântica lexical é diferente da semântica frasal), compreendendo as estruturas internas da palavra num contexto. Hjelmslev (1975, p. 50) tem a seguinte opinião sobre a significação do léxico:

As significações ditas léxicas de certos signos são sempre apenas significações contextuais artificialmente isoladas ou parafraseadas. Considerado isoladamente, signo algum tem significação. Toda significação de signo nasce de um contexto, quer entendamos por isso um contexto de situação ou um contexto explícito, o que vem a dar no mesmo (...)

É importante que o educador ensine ao educando uma maneira de trabalhar com o material de leitura, pois notamos que o sujeito-aluno não possui nenhuma estratégia de leitura ou de estudo. O próprio educando ficará desmotivado se ele não encontrar um objetivo específico para o que vem fazendo ou, então, se as leituras não forem agradáveis. Para tornar a leitura mais agradável, escolhemos textos ou livros que sejam de interesse do educando. Entretanto, há educandos que não têm o hábito de ler em português, o que torna a tarefa do educador mais difícil, nesses casos poderiam ser usados textos menores como artigos da área de trabalho do educando ou de assuntos de que ele goste. 
Quanto aos livros de leitura, damos preferência para aqueles materiais didáticos que contenham o áudio dos capítulos, pois o educando tem a oportunidade de desenvolver seu listening/understanding, melhorando sua acuidade auditiva, além de poder ler o material que escutou após ter trabalhado em seu reading. A leitura possibilita um diálogo, não só de natureza lingüística, mas também cultural, histórica, informativa e social com o educando.

Após a leitura e uma análise classificatória das palavras do texto (ver Apêndice $\mathrm{C}$ ), o educando trabalha o discurso oral, relatando o que foi lido. Os textos curtos, como os de jornal, revista ou textos da internet, ajudam a desenvolver o speaking durante as aulas e servem de parâmetro para mensurar a compreensão da leitura e o desenvolvimento lingüístico do educando, além de mostrarem ao educador o que ainda precisa ser trabalhado com o educando (necessidades ou dificuldades). Dessa forma, os textos estimulam o sujeito-aluno a "trocar idéias" com seu educador e o instrumentaliza no desenvolvimento de seu repertório lingüístico.

O educador sempre parte de um padrão lingüístico, que é a língua institucionalizada, para que exista uma comunicabilidade entre nativos ou não nativos. Assim, ele busca publicações de materiais nas duas grandes variantes da língua inglesa (inglês britânico e o americano). Contudo, o educador precisará demonstrar não somente as diferenças fonológicas, entre as duas grandes variantes, mas também as diferenças lexicais e morfológicas. Além disso, sempre que possível, o educando deve ser exposto aos falantes não nativos da L2, pois cedo ou tarde, ele terá de passar por essa situação em suas viagens a negócios ou na empresa.

Há duas revistas que podem ser usadas como material de apoio tanto para trabalhar a acuidade auditiva como para a leitura e a expressão oral. Essas revistas são a Speak Up e a English to go que acompanham um CD 
ou mídia interativa para que o educando possa ler e escutar os artigos na L2. Os artigos são interessantes e discutem aspectos culturais da L2, dentre outros assuntos.

No capítulo II (2.3), tratamos em linhas gerais sobre a importância do léxico e do uso de bons dicionários para conseguirmos trabalhar de forma eficiente com o educando. Nesse sentido, vamos discorrer um pouco mais sobre esses dois itens.

Primeiramente é importante que o sujeito-aluno entenda o que os signos lingüísticos vinculam naquele universo lingüístico e não se prenda à forma de algumas palavras, que em alguns casos irão variar devido ao contexto em que elas estejam inseridas. Para ilustrar esse fato, tomemos, por exemplo, a seguinte palavra sheep (carneiro) nesse enunciado: Eu vi um carneiro (I saw a sheep); a mesma forma, sheep, não poderia ser usada nessa outra situação: Eu comi carneiro ontem ( $I$ ate mutton yesterday). Tanto o vocábulo sheep quanto mutton são usados em contextos diferentes, com valores diferentes. Para o nativo da língua inglesa, seria claramente distinta a idéia de sheep (animal vivo) e mutton (carne do animal), enquanto na língua portuguesa poderíamos usar carneiro para as duas situações.

Normalmente, o sujeito-aluno conhece o significado mais imediato do vocábulo, ou seja, o sentido com maior co-ocorrência e o dicionário apresenta algumas entradas da mesma palavra, ora com valores gramaticais diferentes, ora com sentidos diferentes, se o educando não tiver suficiente conhecimento para entender a maneira pela qual as palavras são organizadas em um dicionário, provavelmente acabará por empregar o primeiro sentido da palavra pesquisada. É interessante notar que o estudante não se dá conta da polissemia das palavras e, quando 
ocorre, sente-se perplexo e, algumas vezes, incomodado por não saber como poderá empregar uma palavra, adequadamente.

Desse modo, o uso consciente de um dicionário monolíngüe será mais relevante que o bilíngüe, pois esse trará diferentes usos das palavras e traduções, não havendo uma explicação do sentido, que vincula o vocábulo pesquisado pelo educando. A exposição a diferentes situações de uma mesma palavra é importante na aprendizagem, uma vez que o educando passará a perceber o caráter polissêmico das palavras. Nesse sentido, ensinamos ao educando a maneira correta de utilização de dicionários, sobretudo no que diz respeito à polissemia intra-verbetes e a interverbetes, aos quais o educando precisa prestar mais atenção.

Consideremos, ainda, outro aspecto a ser observado e estudado com o educando, os níveis de gradação de um mesmo campo semântico entre unidades lexicais, como por exemplo entre like, desire e love ou cold, cool, warm, hot, dentre outros. Assim, o educador estará fornecendo ao educando subsídios para que ele, como consulente, possa adequar o vocábulo a diferentes contextos e universos de discurso quando necessário. Ao considerar tais aspectos do léxico, o educador estará facilitando a ampliação do universo lexical e assegurando um melhor desempenho discursivo ao seu educando.

Nesse sentido, a tradução não deveria ser incentivada pelo docente, o sujeito-aluno precisa captar o sentido da palavra num contexto, e, posteriormente, construir um sentido para ela em seus enunciados. A tradução requer um outro tipo de desempenho, competência e qualificação que não é necessária para o processo de aprendizagem da L2.

A despeito da perplexidade aludida pelo educando quando se depara com palavras polissêmicas, costumamos apresentar a ele a existência de 
polissemia na língua portuguesa, também, assim, mudaremos o seu ponto de vista sobre as palavras, visto que o educando acredita que a polissemia ocorre somente na L2. O exemplo dado, para que ele entenda a polissemia, em contextos diferentes, é a palavra manga que pode ser um fruto ou parte do vestuário, onde se enfia o braço, dentre outros sentidos. Então, perguntamos ao educando 'o que é manga?', a maioria dirá fruta, pois é o significado mais imediato que virá em sua mente, mas se colocarmos em contexto, prontamente, ele entende a diferença entre $E u$ comi uma manga e Eu costurei uma manga.

Da mesma forma que o educando depreende sentidos diferentes para a mesma palavra na L1, ele também terá de pensar e discernir o sentido das palavras na $L 2$, sobretudo quando estiver procurando uma palavra no dicionário. Outros exemplos devem ser mostrados ao educando para que ele compreenda que isso não ocorre somente na língua inglesa e não é por causa da polissemia que ele não consegue aprender a $L 2$, como pensam alguns educandos. Embora essa polissemia seja clara para o docente, não é clara para o educando. O educando lida com a língua de outra forma, para ele a L2 é somente um meio para comunicar-se com outros indivíduos e tentar fazer parte do mercado de trabalho. Entretanto, se o educando não conseguir compreender a maneira pela qual a língua se constrói e, assim, obter um sentido, ele não poderá chegar a uma aprendizagem significativa da L2.

O educando precisa criar autonomia para trabalhar com os dois dicionários para que ocorra um entendimento mais amplificado do sentido das palavras, pois são níveis de equivalências que será encontrado no dicionário bilíngüe, não uma explanação de sentido do vocábulo que é verificada no monolíngüe. Normalmente, o educando compra pocket dictionaries por uma questão de praticidade, que não é desejável se se pretende estudar o sentido das palavras em contextos mais amplos. Esses 
dicionários disponibilizam sentidos mais co-ocorrentes da língua e são poucos que exemplificam. Os exemplos, dentro dos verbetes, auxiliam o educando a observar os diferentes usos de um determinado vocábulo.

Nesse sentido, o educador recomenda bons dicionários, orientando o educando na utilização deles, levando-o a pensar nas possibilidades de uso de um lexema, que poderá ocupar classes distintas, dependendo da frase. Por exemplo, a palavra Will que, dependendo do lugar ocupado, dentro de uma frase, poderá ser um substantivo ou um verbo. Algumas vezes nos deparamos com mudanças morfológicas e outras sem alteração da forma que, também, devem ser ressaltadas pelo educador e observadas pelo educando quando ele estiver procurando uma palavra no dicionário. Harmer (2002, p. 22) diz o seguinte a esse respeito:

Words can also occupy more than one word class, a fact that is frequently (but not always) indicated by morphological change. The word anger can be a noun or a verb, but if we have to change the $y$ to an $\mathrm{i}$ and add ly. The table below shows the way in which words can occupy different word classes, sometimes without changing, sometimes by altering their morphological shape.

$\begin{array}{cccc}\text { VERB } & \text { NOUN } & \text { ADJ ECTI VE } & \text { ADVERB } \\ \text { Argue } & \text { argument } & \text { argumentative } & \text { argumentatively } \\ \text { Anger } & \text { anger } & \text { angry } & \text { angrily } \\ \text { suggest } & \text { suggestion } & \text { suggestive } & \text { suggestively } \\ \text { Calm } & \text { calm } & \text { calm } & \text { calmly }\end{array}$

Diante disso, é comum o educando não entender a diferença entre palavras que integram o mesmo campo semântico, como por exemplo true (adjetivo) e truth (substantivo), trip (substantivo) e travel (verbo, substantivo ou adjetivo), dentre outras. Somente pela classificação das palavras, é que 
o educando será capaz de saber quando utilizar uma ou outra, mas às vezes a diferença é de emprego do termo, em situações mais específicas como em journey/voyage e wedding /marriage ${ }^{47}$. Sendo assim, o dicionário é um instrumento didático importante para o reconhecimento e emprego correto dos diferentes sentidos, num texto qualquer, além disso, o educando estará mais apto e consciente para trabalhar com o léxico na L2. Com o tempo, o interesse aumenta, consideravelmente, e o educando se torna mais curioso com relação aos diferentes sentidos das palavras nos verbetes e desperto aos diferentes contextos em que a palavra possa surgir.

O processo de aprendizagem de uma língua estrangeira envolve três percursos, ou seja, o percurso do educador juntamente com o educando (trabalho em conjunto); o percurso do educando com seu Ov (percurso individual) e o percurso do educador com o seu Ov (percurso individual) e, por último, é retomado o primeiro percurso, ou seja, o percurso do educando juntamente com o educador. Esses percursos estão continuamente em processo (on going situation) de elaboração e reelaboração, nesse circuito de ensino-aprendizagem, tanto com relação aos meios utilizados pelo educador quanto na relação estabelecida pelo educando em seus estudos de língua inglesa.

No primeiro percurso, instaura-se um processo relacional entre educador e educando. O educador observa e analisa as necessidades de seu educando, troca informações com ele a respeito da $L 2$ e do processo de aprendizagem dele, por sua vez, esse educando participa ativamente

47 Journey: (noun) an ocasion when you travel from one place to another, especially when there is a long distance between the places ( $p .762)$

Voyage: (noun) a long trip, especially by boat or into space (p.1579)

Wedding: (noun) a ceremony in which two people get married (p.1599)

Marriage:(noun) the relationship between two people who are husband and wife ( $p .862)$

Fonte: Macmillan English Dictionary, 2003 
das atividades propostas pelo educador, fazendo suas observações e expondo sua dúvidas e necessidades, também.

Num segundo momento, temos o percurso do educador e do educando que são realizados individualmente. Durante seus percursos individuais, os dois sujeitos envolvidos retomam a aula anterior, um elaborando uma forma de desenvolver um plano de aula, pautado nas necessidades do educando e o outro, exercitando a L2 de acordo com o que foi estudado na aula e solicitado pelo educador, propondo-se, também, a trabalhar de outras formas com a L2 (investimento no saber lingüístico).

Diante disso, o percurso individual do educando deverá encontrar uma forma de lidar com o seu tempo para desenvolver o conhecimento da L2, partindo das observações de seu educador, sendo ativo e reflexivo em seu processo. Quanto ao percurso do educador, ele deve basear-se na entrevista e nos testes realizados no primeiro dia, analisando tanto o relatório de análise das necessidades do educando (needs analysis) quanto o histórico sociocultural e lingüístico do mesmo. Nesse percurso, o educador busca identificar a melhor maneira de estabelecer uma relação entre o saber lingüístico e o educando. É o processo pelo qual o educador escolhe um caminho metodológico mais adequado ao seu educando para que esse consiga um melhor aproveitamento na sua aprendizagem da L2.

Após os percursos individuais (educador e do educando), teremos um feedback do processo como um todo, ou seja, o educando traz para a sala de aula o que foi trabalhado individualmente, comentando suas dúvidas e dificuldades durante a execução das atividades propostas para casa e o educador traz um feedback ao educando sobre os exercícios corrigidos e o desempenho lingüístico nas aulas.

Esquematizando esses percursos durante o processo de ensinoaprendizagem da L2, temos: 
Trabalho em Conjunto

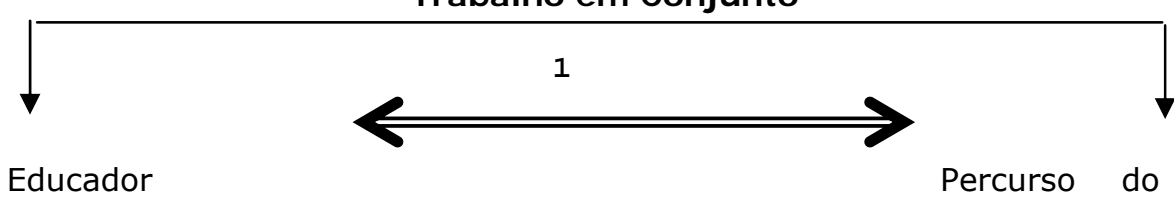

Percurso do Educador Educando
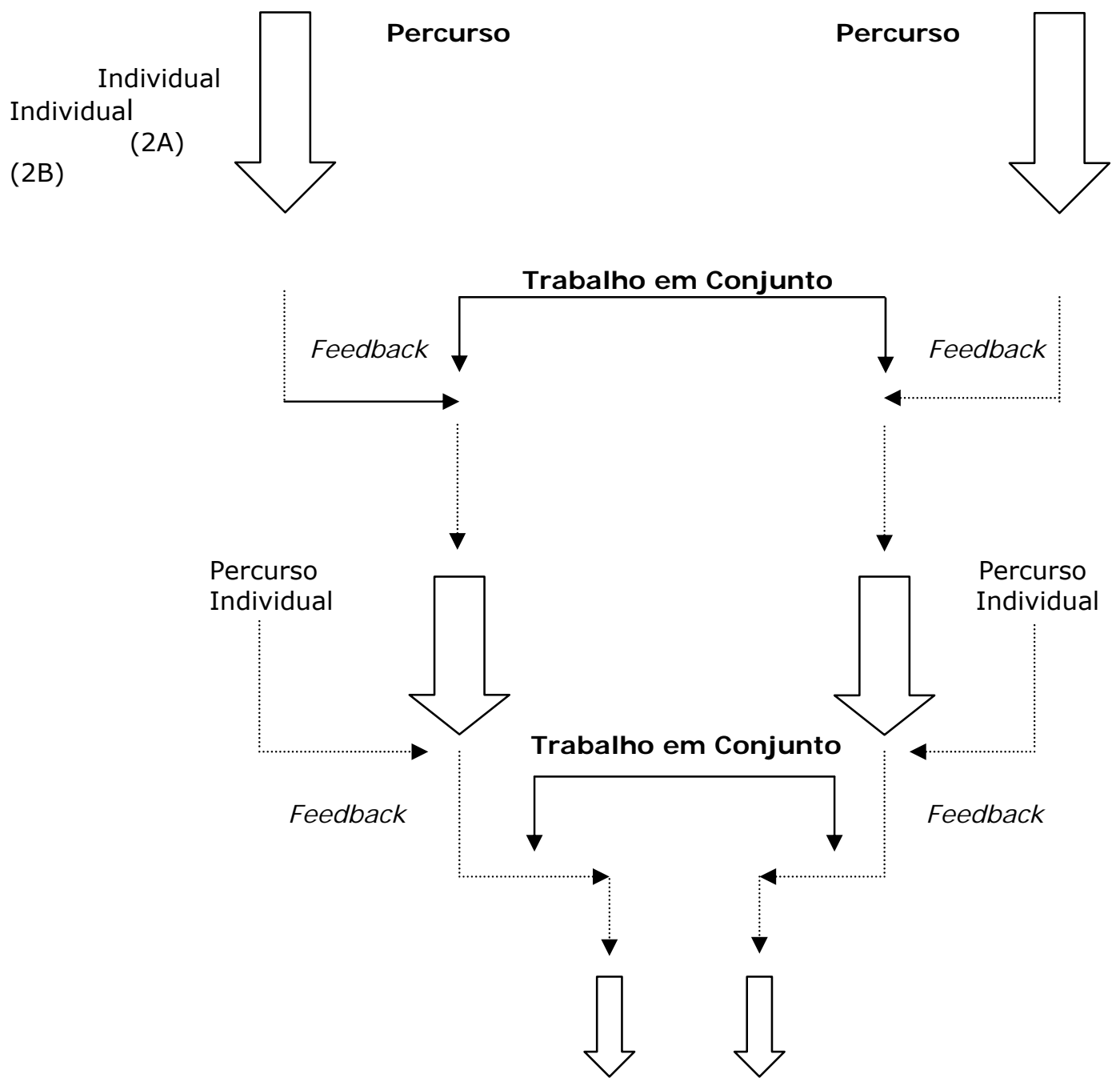

Figura 10: Percursos no processo de ensino-aprendizagem: educador e educando 


\section{CAPÍTULO IV}

\section{IV - LEVANTAMENTO E ANÁLISE DE DADOS}

"O saber é uma relação, um produto e um
resultado, relação do sujeito que conhece
com seu mundo, resultado dessa interação".

Bernard Charlot

Nesta parte da pesquisa, pretendemos relatar o que foi observado durante o período em que os educandos estiveram sob nossa responsabilidade, ressaltando o comportamento deles com relação à aquisição da L2. Além disso, o papel do educador, como facilitador nesse processo, também foi considerado, pois como comentamos anteriormente, tanto o papel do educando quanto do educador precisam estar em relação, ou seja, dentro de uma relação de reciprocidade para que seja instaurado um processo de ensino-aprendizagem significativo.

Assim sendo, dividimos esta pesquisa em três etapas:

$1^{\circ}$ etapa - entrevista (needs analysis) e testes escrito e oral;

$2^{\circ}$ etapa - Revisão dos conteúdos lingüísticos e exercícios escritos e orais e;

$3^{\circ}$ etapa - desenvolvimento e aprofundamento dos conteúdos lingüísticos.

Quando iniciamos esse trabalho em 2001, tínhamos 14 educandos, que faziam aulas particulares (nível básico e pré-intermediário), sem o 
intermédio de uma instituição de ensino e eles seguiram as fases explicadas anteriormente, sendo que essas pessoas se distribuíram da seguinte maneira:

- 1 grupo com quatro pessoas (nível pré-intermediário);

- 2 grupos com três pessoas (nível básico);

- 1 grupo com duas pessoas (nível básico) e;

- 2 pessoas com aulas individuais (nível básico).

$\mathrm{Na}$ primeira etapa, o sujeito-aluno encontra-se, geralmente, desmotivado, sem vontade de voltar a estudar ou ter de estudar uma língua que ele não quer, mas precisa. Sabemos que ele veio procurar aulas de inglês por uma questão de inserção no mercado, pois esse mercado prefere profissionais que tenham o conhecimento da língua inglesa. Dessa forma, ele vislumbra a possibilidade de um cargo melhor na companhia para qual trabalha ou talvez tenha havido algumas mudanças, dentro dessa companhia e, assim, ele precisará estudar a língua inglesa para cumprir algumas exigências que antes não eram necessárias. Essas foram algumas das razões comentadas pelo educando, no primeiro dia do curso e serão importantes para entendermos o que move esse sujeito na busca de seu Ov.

A maior parte dos entrevistados diz ter feito aulas tanto particulares quanto em escolas de idiomas durante um período curto (equivalente a um estágio ou menos). Todavia, esses educandos paravam e recomeçavam depois de um longo período ou no ano seguinte. Esse fato nos chamou a atenção, pois a grande maioria havia parado e recomeçado a estudar a L2 muitas vezes e sentia-se desmotivada. Diante dessa situação, a autoestima desse educandos encontrava-se, em alguns casos, bem abalada, o que corroborava com a falta de vontade desses indivíduos em estudar a 
língua inglesa e, por esse motivo, interrompiam seus estudos constantemente. Alguns acreditavam não serem capazes de aprender, pois já tinham tentado algumas vezes e não conseguiram resultados satisfatórios; outros acreditavam que o "fator idade" estaria influindo em sua aprendizagem e ainda outros comentaram sobre a atitude de seus docentes e o método empregado por eles.

Além disso, a maioria dos educandos entrevistados tinha receio de comunicar-se na L2 e sentia-se insatisfeita com sua não produtividade durante o tempo em que estiveram estudando a língua inglesa. Mesmo aqueles indivíduos que já não se encontravam mais em um estágio inicial de aprendizagem da língua inglesa acabavam retomando estágios anteriores, quando procuravam uma escola de idiomasl. Essa situação desagradava aos discentes, visto que perdiam muito tempo em conteúdos já estudados inúmeras vezes e não conseguiam avançar além do ponto que haviam parado no curso anterior. Além disso, alguns discentes eram avaliados para um estágio mais adiantado, pois conseguiam boas notas no teste escrito, no entanto, não conseguiam se comunicar por meio da expressão oral ou escrita, sobretudo no discurso oral que é o mais importante para as negociações.

Quando perguntado o motivo pelo qual paravam e se afastavam do curso as respostas eram:

1. Tempo;

2. Desmotivação;

3. Docente e/ou o método adotado;

4. Problemas particulares e por último;

5. Dinheiro. 
As perguntas mais recorrentes não só na entrevista, mas no período inicial do curso foram:

“- Em quanto tempo posso aprender inglês?" ou "em quanto tempo vou entender e falar em inglês?"

“- Sou capaz de aprender mesmo depois de velho?"

" - Vou ter de voltar a estudar tudo desde o começo?"

Pudemos notar que havia uma preocupação maior com a questão do tempo, no tocante à idade e a possibilidade de aprendizagem da língua inglesa (idade $x$ aprendizagem) e esses discentes queriam se comunicar 0 mais rápido possível na $\mathrm{L} 2$, notadamente, no discurso falado.

De acordo com alguns educandos, outra questão que os incomodava dizia respeito à perguntas feitas ao docente, que às vezes eram ignoradas ou o docente limitava-se a responder "porque é assim", sem dar qualquer explicação adicional. Alguns educandos relataram que, em seus cursos, eles não tinham oportunidade de expressar-se no discurso oral e, quando havia, era muito pouco, sendo que a maior parte do tempo era tomada pelo discente nas explicações ou para trabalhar o discurso escrito na sala de aula, desta forma, o significante oral acabava sendo comprometido.

Os discentes comentaram também sobre o número de estudantes nas salas que era em torno de 15 pessoas por grupo e que a faixa etária variava entre 18 e 60 anos, o que dificultava o bom andamento das aulas, o aproveitamento deles e a possibilidade de expressarem-se verbalmente na língua inglesa.

De maneira geral, esses estudantes disseram que as metodologias abordadas eram quase sempre as mesmas, ou seja, o conteúdo lingüístico a ser ensinado era escrito na lousa, o docente explicava esses conteúdos e 
utilizava somente o livro didático ou a apostila organizada pela escola. Após a explicação, o docente colocava a fita ou CD de áudio desse livro, para eles escutarem e repetirem e, algumas vezes, utilizava materiais suplementares (música ou vídeo).

Outra reclamação dos discentes dizia respeito à questão do tempo desperdiçado com a correção de lições ou na execução de exercícios escritos durante a aula, não havendo tempo para trabalhar com o discurso oral; além disso, o docente não fornecia aos educandos um feedback dos exercícios realizados por eles. Por essa razão, esses educandos pararam de fazer os exercícios pedidos, pois não achavam necessário, visto que não eram corrigidos ou discutidos pelo docente.

Na segunda etapa, fizemos uma revisão dos conteúdos aprendidos no passado e levantamos os problemas lingüísticos que se encontram fossilizados pelo fato de o docente não ter corrigido ou percebido as dificuldades do discente. Essa revisão foi necessária para que pudéssemos conhecer um pouco mais do conteúdo lingüístico do educando e, assim, avaliar o seu conhecimento da L2. A revisão é, sobretudo, uma estratégia para podermos conhecer o sujeito-aluno e auxiliá-lo em suas dificuldades. Posteriormente, podemos avaliá-lo melhor, colocando-o em um nível de conhecimento lingüístico mais adequado, assim, não precisaremos fazer com que o educando tenha de repetir estágios anteriores da L2. Além disso, nessa etapa, pudemos levantar uma taxionomia dos erros mais recorrentes, os quais foram observados durante os exercícios orais e escritos propostos na aula ou como tarefa. Assim, poderíamos entender as necessidades mais imediatas do educando e suas dificuldades no decorrer do curso.

Nesse período inicial de aprendizagem, os listenings do livro do aluno são difíceis, portanto, ainda não são enfocados. Acreditamos ser mais importante nessa etapa enfocar no significante oral e nos exercícios. A 
motivação aumenta quando o educando começa a lidar melhor com a língua, visto que passa a compreendê-la, acabando por empenhar-se mais. O olhar atento do educador e sua escuta para os sintomas desse sujeitoaluno ajudam o educando a desenvolver uma pré-disposição para a sua aprendizagem, pois esse educando percebe que está aprendendo e existe alguém que realmente $\mathrm{o}$ assiste em suas necessidades, estando pronto para dialogar sobre as dificuldades manifestadas por ele. Para tanto, é necessária a orientação do educador sobre a maneira pela qual o educando deve proceder em seus exercícios, na escolha de materiais didáticos e na utilização correta de tais materiais.

Alguns educandos acreditam não ser necessário fazer as lições propostas pelo educador, pois dizem que não há tempo para isso. Contudo, se discutirmos o porquê da necessidade desses exercícios, eles acabarão se convencendo e percebendo que seu desempenho lingüístico é amplificado quando ele faz os exercícios propostos. Não podemos negar que o fator tempo é realmente um problema para essas pessoas que trabalham na capital paulista, pois normalmente trabalham mais do que às 8 horas previstas por dia e quando chegam em casa não têm vontade de estudar ou fazer os exercícios pedidos. Diante dessa situação, a melhor solução é "negociar" a entrega das tarefas pedidas. Devemos levar o educando a entender a necessidade de exercitar-se pelo menos por 30 minutos ao dia, sendo melhor do que não estudar nada. Com o tempo, o educando aumenta suas horas de estudo espontaneamente, pois percebe que há um melhor aproveitamento das aulas, quando ele estuda e faz os exercícios pedidos, sobretudo quando há uma oportunidade de usar a língua inglesa no seu ambiente de trabalho.

Na terceira etapa, pudemos avaliar o educando e classificar seu nível. Nessa etapa procuramos adotar um livro didático que fosse adequado ao seu nível, além dos materiais suplementares, tais como: textos, material 
audiovisual, jogos, dentre outros, que pudessem complementar as necessidades de cada educando ou que fossem de seu interesse, com o propósito de dialogar com o conteúdo estudado durante a aula.

Quanto às tarefas, notamos que o educando tende a um relaxamento de seu próprio processo quando não é cobrado pelo educador ou, até mesmo, quando o docente não atribui um feedback ao desempenho desse educando durante o processo de ensino-aprendizagem. Comentários como: "Antes o professor não cobrava e, também, não corrigia os exercícios, então eu não fazia" ou "O professor não pede os exercícios e, também, não diz o que estamos errando"; nesse sentido, consideramos esses enunciados, pois são uma prova do relaxamento do educando, quando percebe que o docente não está preocupado em lhe dar um feedback.

É interessante notar que o educando aprecia a atenção do educador. Diante disso, o educando torna-se mais ativo e motivado com seu próprio processo, pois percebe que há alguém que irá ajudá-lo a aprender, da melhor forma possível, o novo idioma. Alguns docentes acreditam não ser necessário requisitar dos educandos os exercícios, pois eles já são adultos e devem saber as conseqüências de seus atos. Contudo, essa atitude é lida de outra forma pelo educando. Tudo irá depender da maneira que abordamos essa questão das tarefas e dos estudos, pois o discurso pedagógico faz o outro /fazerl, ou seja, esse discurso educa o sujeito-aluno a entender o motivo pelo qual ele deveria fazer os exercícios propostos, levando o educando a constatar uma diferença significativa no seu discurso após essa prática.

Nos estágios iniciais da aquisição da L2, há uma dificuldade maior de percepção dos sons. A fala é desenvolvida gradualmente, mas varia muito de indivíduo para indivíduo. Os educandos mais tímidos têm maior dificuldade em comunicar-se e isso demanda muita paciência do educador. 
Durante o processo de aprendizagem, o educando tende a desanimar, pois quer falar tudo o que está pensando na L1 (fase da tradução literal). Todavia, ele aprende a lidar com isso, pois o ensinamos a trabalhar da melhor forma possível com o que aprendeu. Com o tempo, a maneira que ele irá articular suas idéias será expandida, já que ele adquirirá mais conteúdo lingüístico e maior intimidade com as regras da língua estudada. Podemos perceber que, de maneira geral, o educando compreende o texto escrito, em especial, aqueles que se referem a sua área de atuação, mas ainda não consegue se expressar por meio do significante escrito.

Quanto aos listenings dados durante o curso, o educando desestimulase facilmente quando não os entende. Diante disso, precisamos intervir e mostrar a ele que, com o tempo, o filtro fonológico diminui e tanto o léxico quanto a gramática vão sendo assimilados, pois serão armazenados na memória de longa duração e irão se expandir com o tempo e a prática. $\mathrm{O}$ mesmo ocorrerá com o discurso oral e escrito, apesar de o discurso oral pedir uma prontidão mais imediata tanto da memória fonológica e lexical quanto das regras do sistema lingüístico da L2 concomitantemente; por essa razão, o discurso oral demanda um pouco mais de tempo para ser adquirido, tempo esse que será maior ou menor dependendo do educando, pois pudemos comprovar que aqueles educados que se dedicaram mais aos seus estudos lingüísticos otimizaram, rapidamente, seu discurso oral.

A despeito da competência oral e escrita, num primeiro momento, o educando compreende o discurso oral do educador e os textos escritos na L2, entretanto, ele ainda não consegue se expressar em nenhum dos dois significantes. No decorrer do curso, o educando repete frases prontas e fala ou escreve com dificuldade, usando períodos mais simples, sendo ainda observados problemas na percepção auditiva (listenings). Com o tempo, o educando adquire um repertório lexical e gramatical mais amplo e passa a se expressar melhor verbalmente e, conseqüentemente, escreve 
melhor também. Mas ainda demonstra problemas com os listenings, apesar de conseguir compreender o que é enunciado pelo educador. É perfeitamente normal que ele entenda o educador, visto que existe uma adequação da linguagem em seu discurso oral, complementados pela linguagem não verbal ou sincrética, tornando a sua explicação mais acessível.

O educando adulto é muito exigente consigo mesmo. Essa exigência poderá ser um fator positivo, já que o levará a estudar mais ou poderá ser um fator negativo, pois ele poderá paralisar diante de situações mais difíceis da língua, desestimulando-se facilmente ou tornando-se apático, em alguns casos, por essa razão a intervenção do educador é relevante nessas situações. $O$ educando não percebe que ele é um anti-sujeito em seu próprio processo de aprendizagem da L2, assim sendo, parece-nos necessário que o educador construa um discurso que o demova desses sintomas de apatia ou desmotivação diante das dificuldades encontradas por ele em seu percurso de aprendizagem, fazendo a aula ficar mais descontraída, assim, teremos um educando mais tranqüilo.

Além disso, essa exigência pode, na maior parte dos casos, prejudicar a aquisição da L2, pois levantará mais bloqueios na expressão oral. Daí, tranqüilizarmos o educando das possíveis dificuldades. Quando o educando é conscientizado das dificuldades que serão encontradas por ele e da necessidade de uma maior participação em sua aprendizagem, notaremos uma mudança significativa em seu comportamento. Assim, ele passa a adquirir uma outra postura com relação à língua. Todavia, essas dificuldades fazem parte do processo de aprendizagem e, em pouco tempo, o discurso do educador desperta nele um maior entusiasmo, levando-o a se arriscar mais, conseqüentemente, falar mais.

Notamos que alguns educandos têm uma preocupação excessiva em não errar e sentem-se envergonhados quando cometem qualquer erro na 
presença de outras pessoas na sala de aula, sobretudo se um desses educandos for o chefe de alguém no grupo, provavelmente ele preferirá fazer aulas particulares, pois não quer expor suas dificuldades na frente de seus funcionários. O discurso pedagógico precisa intervir novamente quando nota esse tipo de atitude, levando-os a pensar que "errar" é parte do processo de aprendizagem e que a timidez não irá ajudar no desenvolvimento do discurso oral. Além disso, no momento em que eles cometem um erro e são corrigidos mostram não só corporalmente o malestar, mas verbalizam, como um mecanismo de autodefesa, dizendo "Eu sei, eu sei..." ou "Eu sei, mas esqueci”. Entretanto, há outros indivíduos que assumem o erro e simplesmente balançam a cabeça, afirmativamente ou repetem, logo em seguida, o que dizemos quando são corrigidos; outros ainda pedem desculpas pelo erro cometido.

Sabemos que eles ainda se sentem inseguros, especialmente aqueles que provêm de um sistema de ensino que tenha desestabilizado sua autoestima e tenha instaurado um mal-estar com relação à língua e ao papel do docente. Por essa razão, inicialmente, lidamos com essa fragilidade do sujeito, a qual merece todo um respeito e cuidado na forma de lidar com o educando, sobretudo nas explicações ou nas orientações de estudo, pois ele ainda demonstra aquele mal-estar, quando retoma seus estudos de língua inglesa. O educador deve ter em mente que alguns discentes estudaram pouco, outros entraram e saíram de escolas de idiomas e esses são os mais resistentes, justificando toda sorte de erros que cometem.

Quanto mais resistente o indivíduo mostrou-se, mais difícil foi trabalhar com ele, exigindo outras formas de abordagem. Além disso, o processo de aprendizagem da L2 desenvolvia-se lentamente nesse tipo de educando, daí a necessidade de estabelecermos uma confiança entre educador e educando maior, de maneira a fazer que o sujeito-aluno se sentisse mais a vontade para que pudesse recuperar a confiança em si mesmo e no Outro 
(educador), assim, poderia progredir em seu próprio ritmo e desenvolver suas habilidades lingüísticas.

Os educandos mais resistentes não se conformavam com algumas regras da língua inglesa, notadamente quando o campo semântico de uma palavra abrangia mais de um sentido, e protestavam "Por que eles complicam a língua?”; "Português é muito mais fácil que inglês...”; “...assim vou levar a vida toda pra aprender os significados de uma mesma palavra". Após esses comentários, exemplificávamos com algumas palavras da língua portuguesa, demonstrando que ela também possui suas peculiaridades, afinal são culturas distintas e carregam modos diferentes de recortar e interpretar o mundo. Com o passar do tempo, quanto mais consciente sobre questões lingüísticas e culturais, tanto melhor ele se tornava em seu processo, analisando suas próprias dificuldades e olhandoas de forma diferente, o que acabou por promover um bom resultado em seu desempenho lingüístico.

Os educandos citados no início da pesquisa foram comparados a outros educandos da escola de idiomas, onde trabalhamos (aulas individuais e em grupo), perfazendo um total de 45 educandos, sendo que 31 eram educandos da instituição de ensino e 14, nossos educandos de aulas particulares. Entretanto, os educandos da instituição de ensino, não seguiram as fases que foram expostas no modelo-pedagógico, visto ter sido respeitada a metodologia da instituição. Além disso, o número de estudantes nessa instituição variava ao longo do curso, pelo fato de haver uma alta rotatividade de indivíduos, o que dificultou uma pesquisa de longo prazo, uma vez que, para mensurarmos os resultados de aquisição de uma língua, precisaríamos comparar a evolução do educando de um estágio a outro.

Com relação à instituição de ensino, gostaríamos de salientar que, dificilmente, conseguíamos manter os mesmos grupos em um mesmo 
período, pois a instituição disponibiliza horários mais flexíveis e trabalha em grande parte com indivíduos de corporações, o que significa dizer que, normalmente, a empresa paga $\circ$ curso ou módulos ${ }^{48}$ para seus funcionários e, dessa forma, a instituição apresenta um plano de trabalho, horas, grupos e horários que são convenientes para a empresa e não para as necessidades reais do educando; essas aulas eram ministradas na escola ou na própria companhia (in-company classes). Portanto, se por algum motivo o grupo ou um dos discentes não pudesse fazer mais aulas naquele período, automaticamente seriam transferidos para um outro grupo ou se um deles não pudesse dar continuidade ao seu curso, a instituição abriria um precedente e o educando poderia voltar a fazer aulas, em uma outra época do ano ou período para cumprir o acordo firmado pela escola com a empresa.

Além disso, o livro didático e o material usado foram escolhidos pela instituição, independente das necessidades dos educandos. A única maneira que encontramos para trabalhar de uma forma mais personalizada, sem interferir no que havia sido acordado pela escola com a empresa, era provendo o educando de materiais suplementares para que houvesse um meio de sanarmos os problemas que ocorriam ou, então, sugerindo aos educandos outras formas de trabalhar por si mesmos.

Nesses cursos, havia um tempo estipulado para finalizar o estágio, dentro do pacote de horas, que foi acordado entre a empresa e instituição de ensino; nesse sentido, deveríamos ficar limitados ao tempo e planejar muito bem as aulas para conseguirmos ministrar os conteúdos lingüísticos daquele estágio. Diante dessas circunstâncias, era praticamente impossível trabalhar de forma mais produtiva e individualizada, respeitando

$48 \quad$ Esses cursos, no formato de módulos são chamados de Short ESP Courses que variam de 12 a 48 horas e são cursos mais curtos com um enfoque específico de aprendizagem, como por exemplo, módulos de telephoning, negotiations, presentations, etc. 
o 'tempo interno' de cada educando. A escola de idiomas adotou livros e materiais suplementares, com vistas a um ensino da língua inglesa nos moldes do mundo empresarial que, nos dias atuais, é considerado um diferencial na área de ensino de línguas (Business English).

Como mencionamos anteriormente, tínhamos de lidar com a dificuldade de rotatividade, que é muito grande nesses acordos feitos com a empresa, então, era muito comum funcionários que estavam estudando e alguns fazendo progressos na L2 serem transferidos para uma outra cidade repentinamente ou terem de ausentar-se das aulas por questões de trabalho, pois a empresa pedia aos seus funcionários para viajarem a outros estados ou países. Essas ausências poderiam durar alguns dias ou alguns meses, dificultando não só o rendimento do educando, que em alguns casos caia drasticamente, mas também prejudicava o desenvolvimento do grupo como um todo.

Diante desse fato, o que inevitavelmente ocorria era um distanciamento de ordem lingüística entre os colegas da aula de inglês com aquele que estava viajando; entretanto, se o educando tivesse de ausentar-se por um longo período, o grupo poderia ter mudado de horário ou nem existir mais. Se antes tínhamos um grupo de pessoas em um nível de conhecimento lingüístico uniforme, teríamos, em um segundo momento, um desequilíbrio dentro do mesmo grupo, levando à desmotivação do curso e do grupo como um todo.

Nessas circunstâncias, alguns integrantes desse grupo acabavam procurando aulas individuais (em alguns casos essa parecia ser a decisão mais acertada para aqueles que queriam continuar e progredir) ou, então, eles paravam de estudar. Aqueles que continuavam indo às aulas, com o tempo desestimulavam-se também, pois o seu colega estava sempre atrasado em relação aos outros integrantes do grupo, o que dificultava o andamento das aulas, não só durante os trabalhos em duplas, mas quando 
algo era explicado na aula e a pessoa que havia se ausentado por muito tempo não conseguia acompanhar, precisando de uma atenção maior. Dessa forma, tínhamos de interromper a aula para explicar ao educando o que os outros já haviam estudado anteriormente. Infelizmente, a escola não disponibilizava nenhum serviço de acompanhamento para esses casos, acarretando desmotivação desse educando, que precisava se ausentar freqüentemente.

Hoje em dia, é muito comum que as empresas disponibilizem uma verba parcial ou total nos cursos de inglês para seus funcionários. Diante disso, percebemos que aqueles discentes que tinham o curso pago integralmente faltavam muito mais às aulas ou chegavam sempre atrasados, não fazendo o que era pedido e demonstrando mais displicência durante o curso ao contrário daqueles que pagavam uma parte do curso e que acabavam se envolvendo mais nesse processo de aprendizagem. Chegamos a comentar essa atitude nas reuniões de docentes para podermos saber se essa situação ocorria somente em nossas aulas; contudo, esse comportamento também era comum em outras aulas, não só nas de língua inglesa.

Devido a essa situação, o $\mathrm{RH}$ de algumas empresas passou a pedir para a escola de idiomas ou o professor particular a freqüência dos educandos e um relatório que pudesse atestar tanto o desempenho do funcionário quanto o conteúdo desenvolvido para poderem acompanhar a evolução de seus funcionários, visto que a empresa está disponibilizando uma parte de seu capital e investindo neles. Quando ocorriam as faltas dos educandos, essas precisariam ser justificadas ao $\mathrm{RH}$ e as notas deveriam ser boas para que eles continuassem a receber esse benefício da empresa, provocando, em alguns casos, uma mudança significativa no papel dos educandos nas aulas. Assim, elaboramos um Follow Up para que a empresa pudesse acompanhar o desenvolvimento de seu 
funcionário, sendo que o educando também poderia avaliar seu próprio desenvolvimento durante o processo de aprendizagem.

Além disso, foi pedido ao educando que nunca respondesse algo na prova que não soubesse, como é comum ele fazer para conseguir uma nota melhor. $\mathrm{O}$ educando deveria sinalizar na prova aquelas questões que teve dúvida ou não sabia, pois poderíamos discutir posteriormente. Esse procedimento melhorou a performance dos educandos, pois além de deixálos mais atentos, conscientes e envolvidos, eles sabiam que iríamos discutir os erros e que a avaliação não era apenas feita pelo que foi produzido no momento do exame, mas por todo um processo que vinha sendo desenvolvido desde o início do curso (on going process).

Cabe ressaltar que esses educandos (instituição de ensino), mesmo não tendo paticipado das outras etapas do modelo-pedagógico (etapas 2 e 3) auxiliaram no nosso levantamento de dados, sobretudo na $1^{\text {a }}$ etapa (entrevista), em que pudemos levantar as impressões dos educandos quanto às metodologias aplicadas, ao comportamento do docente e ao seu próprio processo de aprendizagem na L2.

Assim sendo, preferimos escolher, como parâmetro de observação mais pormenorizada, apenas as 14 pessoas das aulas particulares. Esses educandos seguiram as 3 etapas propostas. No entanto, de 2001 até 2006, das 14 pessoas, apenas 7 continuaram participando das aulas de língua inglesa, sendo que alguns educandos migraram para aulas individuais e, ainda, continuam estudando conosco. Dessa forma, pudemos mensurar os progressos desses indivíduos, de um estágio a outro, que foi significativa e eficiente, com um alto grau de satisfação, não só por parte dos educandos, mas também da empresa para a qual trabalham. A migração desses educandos para aulas particulares ocorreu pelos seguintes fatores:

> Demissão ou; 
> Horários não compatíveis entre eles ou;

> Problemas pessoais (filhos, graduação, falta de tempo ou dinheiro).

Aqueles educandos que utilizavam em seu trabalho a L2 estavam sempre mais dispostos e motivados a fazer exercícios tanto orais quanto escritos e participavam mais de seu processo de aprendizagem. Por outro lado, aqueles que não utilizavam o idioma, sentiam-se desmotivados; entretanto, esses educandos continuaram estudando, pois acreditam na possibilidade de um emprego melhor ou numa melhor colocação no mercado, pois estariam mais preparados para uma eventual entrevista ou teste em inglês, já que alguns deles perderam oportunidades para trabalhar em multinacionais aqui no Brasil ou no exterior por não terem $\mathrm{O}$ conhecimento da língua inglesa, apesar de serem ótimos profissionais. A perda de uma chance para trabalhar fora do Brasil ou em outra companhia, e, até mesmo, um cargo melhor, levou muitos desses educandos a procurarem aulas de inglês, já que vislumbravam uma oportunidade no mercado, um diferencial que pudessem mostrar às empresas.

Outro dado importante que notamos foi a diferença entre as aulas individuais e em grupo. O número de estudantes em uma sala de aula influi diretamente na produção e progresso de seus integrantes, sobretudo para o desenvolvimento do discurso oral, quanto mais integrantes, menos tempo de produção oral para cada integrante e menos possibilidades de trabalharmos de forma personalizada. As aulas individuais são mais personalizadas e acabam por otimizar o desempenho lingüístico do educando rapidamente, notadamente na produção oral, além de poderem acompanhar o ritmo do educando. Apesar de as aulas em grupo possibilitarem maior interação e troca de informações entre os integrantes, a produção oral leva mais tempo e as metodologias aplicadas são adaptadas ao grupo. Manter um grupo coeso é muito mais complicado, pois alguns integrantes faltam, outros entram de férias e apesar do objetivo 
ser o mesmo, ou seja, aprender a L2, o desejo manifestado em cada integrante será diferente, conseqüentemente, teremos produtividade e desempenho lingüísticos distintos.

Atualmente, todos aqueles educandos que migraram para as aulas individuais não querem mais fazer aulas em grupo, pois perceberam que houve um maior aproveitamento das aulas e desenvolveram-se muito mais rapidamente nessas aulas individuais. Nesse tipo de aula, one-to-one, há mais tempo para discutir assuntos que interessam aos educandos, além de poderem esclarecer suas dúvidas sem sentirem-se expostos ou embaraçados. Enfim, os educandos preferem ter uma aula mais personalizada. A motivação deles aumentou e o interesse pela aula também, acabando por provocar um desenvolvimento muito mais rápido nesses educandos.

Alguns deles passaram a procurar outras formas de desenvolver seu próprio processo de aprendizagem. A atenção é maior e estão mais conscientes de suas dificuldades e do que precisam fazer para melhorar seu desempenho na língua inglesa. No estágio atual em que se encontram esses educandos, eles já conseguem compreender o material de áudio e vídeo, além de alguns filmes e músicas, por isso, sentem-se mais seguros em participar de reuniões em inglês ou vídeo conferências em seu trabalho, até mesmo participar de conversas informais com cliente durante os jantares de negócios.

A dificuldade observada durante o curso era sempre discutida com o educando, além disso, os erros que ocorriam durante a produção escrita e/ou falada foram discutidos também, levando-o a pensar sobre o seu erro tanto no discurso oral quanto no escrito após termos ressaltado os problemas encontrados nesses discursos. O educando era corrigido no momento em que ele se expressava verbalmente ou anotávamos os erros e comentávamos logo após sua fala, ora fazendo perguntas para ele sobre 
os erros cometidos ora levando-o a deduzir os problemas encontrados em sua produção discursiva. Assim, poderíamos avaliar se o educando vinha prestando atenção nas aulas ou saber se ele ainda não havia entendido algo na L2. Essa técnica de correção mostrou-se significativa a partir do momento que o educando passou a adquirir maior consciência sobre seus erros e foi capaz de avaliar suas próprias necessidades durante 0 processo de aprendizagem da L2.

Alguns educandos desta pesquisa já se encontravam em uma fase intermediária de aprendizagem da L2, entretanto, apresentavam problemas de nível básico que, provavelmente, não haviam sido ensinados devido a uma metodologia falha ou não foram trabalhados o suficiente, impedindo o educando de progredir em seus estudos lingüísticos.

Logo após passar por aquelas etapas iniciais do modelo lingüísticopedagógico, o educando sente-se mais familiarizado com a língua e está apto e seguro para começar um estágio da aprendizagem ou recomeçar o estágio em que estava anteriormente. O conteúdo lingüístico do estágio em que o educando se encontra é desenvolvido passo a passo, e toda vez que há uma dificuldade ou um problema é notado, são dados exercícios que visam corrigir os problemas de ordem sintática, semântica, morfológica ou fonológica. Nessa fase, o educando está mais desperto para a língua, o olhar é mais atento e ele mesmo sente-se mais preparado, decodificando e codificando com maior segurança um discurso na L2. A inibição daqueles educandos mais calados vai se perdendo e, com o passar do tempo, ele acaba por participar cada vez mais da aula e não se importa com os erros.

Após os procedimentos que são dados com relação às leituras, aos listenings e exercícios de modo geral, o educando torna-se cada vez mais consciente e auto-suficiente, portanto, estuda mais e quando percebe que está aprendendo, procura maneiras para melhorar seu desempenho lingüístico. Além de adquirir consciência de suas dificuldades na língua- 
objeto, ele tenta também encontrar maneiras de resolver essas dificuldades, perguntando se o procedimento de estudo está correto e o que mais ele poderia fazer para melhorar seu desempenho lingüístico, em uma das habilidades da L2.

Nos textos escritos, a compreensão de uma significação gramatical dos lexemas e dos morfemas começa a ser percebida cada vez mais, já que há um treino constante de leitura de livros e pequenos artigos ou textos da área de interesse do educando, que são analisados em nível estrutural da frase e da palavra, levando o educando a desenvolver um olhar mais atento às estruturas gramaticais contidas nessas frases e/ou nas palavras.

Com a prática, o educando começa a identificar e compreender cada vez mais as palavras em contextos diversos e posicionamentos distintos, dentro da frase ou do mesmo texto, visto que há formas que se assemelham, mas tem significados diferentes. Frases como as que se seguem são algumas das dificuldades encontradas pelo sujeito-aluno no início de sua aprendizagem e são apresentadas ao estudante e estudadas com ele. Assim, vejamos alguns exemplos de homônimos ( homografia e homofonia) :

I watch TV e He bought a watch;

I can dance the tango e He has a coke can;

I like my mother e he's like his father;

He's ok e his house / see e sea / heir e air / right e write / meet e meat / red e read / piece e peace / our e hour / to, two e too / I e eye / eight e ate / for e four / sun e son / by e buy / hear e here / there e their / where e wear (mesmo som, mas são formas e sentidos diferentes ou mesma forma e sentidos diferentes. Quando o educando ouve essas frases ou palavras, 
ainda não consegue saber a diferença, pois se pedirmos para ele escrever o que foi dito, poderá usar uma forma ou outra, entretanto, quando ele lê identifica prontamente a diferença).

As formas contraídas (short forms) também merecem uma atenção especial e, geralmente, o educando confunde os exemplos a seguir:

\begin{tabular}{|c|c|}
\hline She's working at IBM & She's played tennis for two years \\
\hline She's a good student & \multicolumn{1}{|c|}{ She's got a car } \\
\hline Her mother's car & She's at her mother's \\
\hline I'd like a coke, please & $\begin{array}{l}\text { I'd lost my passport I told the } \\
\text { police }\end{array}$ \\
\hline
\end{tabular}

Após alguns exercícios de observação e discriminação das estruturas gramaticais em uma frase, o educando passa a entender o motivo de sempre pedirmos que ele diga qual a função de um determinado termo em uma frase ou o porquê de pedirmos exercícios da gramática. Com espanto descobrem que nem sempre um lexema que tenha a terminação "ING" será necessariamente um verbo ou que a mesma palavra em contextos diferentes poderá assumir significados diferentes (polissemia) e que, dependendo da palavra, quando em posicionamentos diferentes dentro da frase, também assume uma outra classificação morfológica; diante disso, ele aprende que é o contexto de uso que determina a função e sentido da 
palavra. Quando o educando começa a perceber essas pequenas diferenças é que ele começará a aprender realmente, pois está mais consciente do sentido que as palavras vinculam. A compreensão desse educando com um texto qualquer é amplificada, sua leitura torna-se mais apurada e isso refletirá na expressão escrita, já que agora entende melhor as estruturas sintáticas, semânticas e morfológicas da L2.

Com relação ao discurso falado, notamos que desenvolve-se aos poucos e depende muito da personalidade do indivíduo. Pessoas mais extrovertidas são mais ousadas e arriscam-se mais, ao contrário de pessoas introvertidas, visto que é mais difícil fazê-los produzir um discurso falado. É interessante notar que, em ambos os casos, o desenvolvimento da compreensão de texto escrito é adquirida mais rapidamente, entretanto, a fala é um processo mais lento, pois demanda maior esforço da parte cognitiva. Como a L2 ainda está se desenvolvendo, é normal que eles pensem em português e depois vertam para o inglês, procurando expressar-se da mesma forma que na L1.

Com o tempo, o educando aprende que não é correto fazer essas traduções literais, pois provocam ruídos na comunicação, levando o sujeito-aluno a uma frustração. Assim, o educando adquire o hábito de expressar-se de forma simples e, aos poucos, começa a produzir períodos compostos, mesmo com algumas dificuldades.

O retardo na fala na fase inicial de aprendizagem deve-se a essa tradução que é buscada pelo sujeito constantemente; ele ainda não tem a preocupação de procurar entender o sentido que é articulado naquele contexto, pensando na idéia do que é construído. Apenas conscientizando o educando de simples exemplos em português e comparando-os ao inglês é que será possível um discernimento maior do educando quanto às palavras, expressões e convencionalismos da língua. 
Durante 0 desenvolvimento do listening/understanding, pudemos observar as seguintes dificuldades quanto à discriminação auditiva:

> Na emissão de sons do "TH", por exemplo: Think e that.

> Na emissão do "R" retroflexo, como em road.

> A diferença entre as emissões de vogais curtas e longas como o som do "i", por exemplo, em sheep e ship ou do "U", como em book e boot.

> O som de lexemas que iniciam com o "T", como em teacher, geralmente, produzido igual ao fonema $/ \mathrm{t} / \mathrm{f}$.

> Dificuldades em diferenciar os sons finais de lexemas, que possuem o gramema "ED" nos verbos regulares, visto que existem três sons, /d/, /t/ e /id/, como em played, watched e needed.

> Dificuldade em produzir o "H" aspirado, como em hen. O português não emite esse som que é produzido na laringe, comprometendo o entendimento do educando para começar a perceber e emitir, posteriormente.

> A diferença entre os sons do "SH" e do "CH", como em ship e chip ou chair e share. O educando tende a ler tanto um quanto outro da mesma forma que leria em português, ou seja, sempre com o som do " $\mathrm{CH}$ " / / / da língua portuguesa. É uma interferência da língua materna que provoca um ruído na comunicação e mudança de significado por causa da mudança de signo.

> Dificuldade em lembrar do " $\mathrm{S}$ " final na $3^{\circ}$ pessoa do singular no Present Tense, sobretudo nos estágios iniciais da aprendizagem da 
L2. Todavia, quando é indagado sobre a regra desse tempo verbal, o educando corrige prontamente.

As falhas na discriminação auditiva parecem advir da falta de percepção do som, já que o sujeito-aluno ainda não consegue discriminar corretamente os sons da L2 para poder emitir uma palavra. $\mathrm{O}$ fato de $\mathrm{O}$ educando não pronunciar corretamente um som, levará à mudança de signo ou a uma não identificação vocabular pelo destinatário. Nessas circunstâncias, precisaremos criar o hábito no educando de estudar a pronúncia, de voltar sua atenção não só para a articulação ou emissão dos sons, mas para a discriminação auditiva deles também. Essa prática deve ser uma ação consciente por parte do educando para que haja um melhor desempenho na L2, quanto mais ele treinar esses sons, melhor será sua memória fonológica. O estudo dos sons relacionados aos símbolos convencionados melhorou a acuidade auditiva do educando e a articulação.

Para aqueles educandos que tinham maior dificuldade nos listenings, foi pedido para fazer a transcrição de diálogos do livro do aluno para servir de treino na ampliação da acuidade auditiva. Notamos que esse procedimento ajudou a melhorar a percepção auditiva do educando, sendo que o filtro fonológico foi rebaixado e o encadeamento de palavras e frases melhorou também. Dessa forma, foi possível para o educando sincronizar uma idéia à palavra ou sentença mais prontamente, uma vez que existe um retardo na compreensão do que é emitido por alguém no início da aprendizagem, pois ainda há uma tradução mental do que é enunciado na $L 2$.

A leitura e textos suplementares auxiliaram na ampliação do léxico e na compreensão da carga semântica das palavras em um determinado contexto. A dificuldade maior é a discriminação auditiva que parece ser a 
última a ser adquirida, mesmo que o discente já consiga conversar um pouco na língua inglesa, contudo, o educando compreende bem a fala de seu educador, pois o conhece bem e comunica-se com ele constantemente.

Pudemos perceber que a atitude que o educando desenvolve durante a aprendizagem da nova língua refletirá diretamente em sua performance lingüística. Então, se ele tiver o hábito de fazer exercícios e empenhar-se por aprender de outras formas, ler mais e ouvir também, com certeza, teremos um sujeito mais desperto ao que será ensinado em aula, ou seja, uma pessoa pronta para interagir ao que lhe é ensinado em sala de aula e a responder ou, pelo menos, tentar responder ao que lhe é perguntado, pois ele põe em prática o que vem estudando por si mesmo. Assim sendo, poderá ser mais participativo em aula, colocando em questão o que percebeu ou não entendeu enquanto estava estudando e se exercitando.

Notamos que, em alguns casos, ocorre um hiato entre o docente e o discente no processo de ensino-aprendizagem. Esse hiato pode levar o educando a uma falta de motivação e envolvimento em seu percurso de aprendizagem. Sendo assim, esse hiato pode ocorrer quando o educador:

1. Não está atento às necessidades do sujeito-aluno;

2. Desconhece o perfil do sujeito-aluno (questão sócio-histórico-cultural e lingüística do sujeito);

3. Atitude corporal do docente (gestos corporais e faciais);

4. Tem sempre o mesmo formato de aula. Não é uma aula dinâmica. Os materiais didáticos são sempre os mesmos (lousa/Flip chart, livros didático e um aparelho de som). 
Por outro lado, esse hiato poderá ser instaurado pelo próprio educando quando:

1. O sujeito-aluno não tem seu Ov bem definido ou/e;

2. O educando não gosta do idioma ou/e;

3. O educando antipatiza com o docente ou/e;

4. Filtro afetivo muito alto e baixa auto-estima ou/e;

5. Não envolvimento ou comprometimento em lquerer-saberl e aprender, portanto não faz o que for necessário para sanar suas dificuldades e tentar ir além daquele ponto de inércia.

Portanto, podemos perceber que tanto o docente como o discente podem ter uma parcela considerável nesse hiato e, conseqüentemente, a falta de motivação de ambos. Todavia, cabe ao educador estar ciente desses fatores e conversar com o educando sobre o papel do educador no processo e o que ele espera desse sujeito-aluno durante o processo de ensino-aprendizagem. Contudo, se o hiato foi criado pelo próprio educando, o educador deverá levá-lo a sair de um estado de inércia, desmotivação ou mal-estar relacionados ao passado. Assim sendo, o discurso pedagógico pode influenciar diretamente na aprendizagem e afetar o educando de maneira positiva ou negativa. Quando estimulamos o educando, percebemos uma melhora no seu percurso de aprendizagem. Podemos construir um simulacro positivo para esse sujeito-aluno e fazê-lo trabalhar para alcançar um desenvolvimento cada vez melhor. Por outro lado, poderemos construir um simulacro negativo se não respeitarmos esse educando, seu histórico, crenças, valores e saberes. O ethos, que é 
construído pelo docente, manipula o discurso de maneira positiva ou negativa e acaba por influenciar o processo de aprendizagem do indivíduo.

Os fatores inibidores da aprendizagem, nesse processo de ensinoaprendizagem, configuram-se da seguinte forma:

1. Fatores emocionais relacionados ao passado (mal-estar com relação ao docente e aprendizagem);

2. Baixa auto-estima;

3. Pressão do mercado de trabalho;

4. Alto grau de ansiedade;

5. Déficit cognitivo ou intelectual rebaixado; e

6. cansaço.

Assim sendo, levantamos alguns dados sobre o papel do educador e do educando nesse processo de ensino-aprendizagem. Primeiramente, vamos discorrer sobre o que é necessário construir num discurso pedagógico em que o educador deveria prestar mais atenção durante 0 planejamento de uma aula:

> Propiciar ao educando condições de desenvolver sua competência e desempenho lexicais.

> Otimizar o tempo da aula para discussão de textos, portanto, um tempo maior para a interlocução entre educando e educador.

> Deixar o educando refletir sobre as suas dificuldades e erros cometidos em seus discursos, levando-o a criar uma atenção maior tanto na expressão escrita quanto na oral. 
> Fazer bom uso de um material didático condizente às necessidades do educando e utilizar uma metalinguagem adequada ao estágio do educando, ou seja, ao nível de aprendizagem dele.

> Dar instruções claras ao educando sobre os exercícios a serem desenvolvidos.

> As aulas em grupo devem conter apenas três pessoas, no máximo quatro, para que a produção oral não seja prejudicada e possa haver uma atenção mais personalizada a cada integrante desse grupo.

> O discurso pedagógico não deve ser autoritário e as tarefas são sempre negociadas com o educando.

> O educador desenvolve um plano metodológico partindo do histórico do indivíduo, que foi levantado na $1^{\text {a }}$ etapa, e, com o tempo, outros planos metodológicos devem ser (re)elaborados de acordo com as necessidades que vão se apresentando durante o processo de ensino-aprendizagem.

> O educador deve fazer com que o educando participe mais durante a aula, sobretudo no discurso oral.

> Deve haver mais diálogo entre educador e educando sobre questões relacionadas à aprendizagem da língua.

> Não limitar-se à lousa ou ao livro didático. Quanto mais diversificado for o material e a aplicação de diferentes métodos e técnicas, melhor será para a aprendizagem e o ritmo/dinâmica da aula serão sempre diferentes. 
> $\mathrm{O}$ educador precisa trabalhar as quatro habilidades (writing, speaking, listening and reading), sobretudo o significante oral, durante a aula. Contudo, o significante escrito é sempre pedido como tarefa a ser desenvolvida em casa. De qualquer forma, o educador precisa inculcar em seu educando a necessidade de sempre treinar essas habilidades, criando hábitos nesse sujeitoaluno.

> O feedback, tanto oral quanto escrito, é muito importante para o educando. As correções devem ser sempre discutidas com ele, observando se é capaz de corrigir e explicar o erro cometido em suas lições.

> Se a dimensão do olhar do educador for muito técnica e o educando for corrigido ou cobrado pelos seus estudos de uma maneira muito contundente, provavelmente o educador afastará o sujeito-aluno. Assim, o educador observa a maneira que o educando aprende e a maneira que ele se comporta para conseguir achar uma forma de fazer o educando Ifazerl o que for necessário para o desenvolvimento de sua aprendizagem, respeitando as dificuldades com que esse indivíduo se depara durante o seu percurso.

> Devemos usar métodos e técnicas mais condizentes com a época em que o educando se encontra, utilizando sobretudo os meios tecnológicos que estão no mercado. Entretanto, precisamos saber como transmitir um conhecimento lingüístico por meio de diferentes técnicas e métodos, já que é uma condição imprescindível para o bom desempenho do educando.

> Aulas com um ensino bem orientado e reflexivo, além do uso de materiais distintos, irão aumentar o interesse do sujeito-aluno, diminuindo o cansaço e a resistência ao novo, além de 
aperfeiçoarem o saber em diferentes contextos, levando o sujeito a uma prática mais ativa e engajada em seu próprio processo de aprendizagem.

>As aulas devem ser sempre criativas, dinâmicas e bem humoradas para que possamos despertar o interesse do educando. A diversidade ainda é a melhor forma de amplificarmos o conhecimento.

> Inculcar a necessidade de estar sempre em contato com a L2 durante o processo de aquisição.

> O educador deve ser sensível às necessidades de seu educando, orientando-o para um melhor aproveitamento das aulas e, sobretudo, trabalhando nas dificuldades e nos sintomas que ocorreram pela falta de qualidade no ensino de uma língua estrangeira.

> O discurso do educador deve produzir um /querer-fazer/ no outro.

> Prestar atenção no discurso oral/escrito do educando e, posteriormente, traçar um plano metodológico.

$>0$ educador deve fazer o educando ser mais reflexivo no seu processo de aprendizagem.

> É importante resgatar a confiança do educando que, em muitos casos, já está abalada. $\mathrm{O}$ educador precisa mostrar ao educando que a aprendizagem depende da disponibilidade dele para /quereraprenderl, de um desejar participar ativamente nesse processo.

> A desmotivação do educador leva à desmotivação do educando. Para tanto, o educador deve pensar na forma que está ministrando 
suas aulas e estar sempre atento ao educando, pois ele reflete o andamento da aula.

Quanto ao educando, pudemos levantar alguns problemas que impossibilitam ou retardam sua aprendizagem como:

> A preocupação quanto ao tempo de aprendizagem da L2 e a cobrança de si mesmo podem levar a um bloqueio ou retardamento no processo de aprendizagem.

> Falta de tempo e disponibilidade para estudar.

> Desmotivação pelo tipo de metodologia empregada.

> A tensão e o cansaço interferem na atenção e na memorização, conseqüentemente, na cognição do indivíduo, pois diminuem a capacidade cognitiva do educando.

> A baixa auto-estima (filtro afetivo alto) influencia no processo de aprendizagem.

> A falta de motivação faz o educando desistir de seu processo de aprendizagem.

> A falta de planejamento em seus estudos (= tempo para estudar) acarreta um retardo no seu processo de aquisição.

> A falta de comunicação com o educador também acarreta um retardo no processo de aprendizagem do educando, visto que ele não comenta as suas necessidades ou dificuldades. Além disso, há educandos que não fazem perguntas porque têm receio de exporem-se, de perguntar ou por serem introvertidos. 
> As cobranças da empresa ou do chefe levam o educando a se preocupar e, muitas vezes, seu desempenho acabará sendo comprometido, visto que tem medo de reprovar ou não conseguir suprir as suas próprias expectativas e as da companhia onde trabalha. Por outro lado, o fator exigência ou cobrança, por parte da companhia, pode acabar gerando um /fazer/ mais empenhado do educando.

> De maneira geral, o educando não sabe utilizar apropriadamente o dicionário, comprometendo a construção do sentido na L2.

> Interferência fono-morfológica e morfo-fonológica.

> Dificuldades tanto na percepção dos sons, que não fazem parte do inventário de sons do português, quanto na emissão desses mesmos sons, que, inicialmente, configuram-se como um problema, pois ocorrem ruídos na comunicação devido à interferência do sistema lingüístico da L1.

> A falta de inclusão do sujeito, em seu próprio processo de aprendizagem, acarreta problemas na aquisição.

> Dificuldade em perceber corretamente um lexema e/ou gramema.

Desse modo, o que provoca o distanciamento do educando com seu Ov, segundo os dados levantados nas entrevistas, são os seguintes itens:

1. O método e/ou docente;

2. A falta de motivação;

3. O fator tempo para dedicar-se aos estudos e;

4. As viagens de negócios (em alguns casos). 


\subsection{Análise semiótica dos dados levantados}

A análise está centrada nas figuras dos dois sujeitos (educador e educando) envolvidos no circuito de ensino-aprendizagem. Faz-se necessário que ambos trabalhem em seus próprios percursos, respaldados em seus objetivos; todavia, eles precisam, também, fazer um percurso juntos para que o processo de ensino-aprendizagem seja instaurado.

Sabemos que o ato de comunicar necessita de um emissor e um receptor para que ocorra a troca de informação (transmissão de um código, recepção e decodificação desse código), devemos considerar a estrutura de troca de dois enunciadores-interlocutores: educador e educando. Um tem a tarefa de fazer o outro entender uma língua estrangeira e esse outro, por sua vez, interpreta esse fazer segundo as crenças que foram construídas por meio de suas vivências (simulacros).

Dessa forma, a narrativa desse ato de comunicação será construída baseando-se nos sujeitos, anti-sujeitos e objetos de valor. O objetivo final do percurso dos sujeitos é o de chegar a uma sanção positiva (performance) e uma conjunção eufórica do Ov, que antes se encontrava disfórico no início de sua trajetória, chegando a um percurso final de sucesso, declarando-se competente, visto que o educando conseguiu uma transformação modal, ou seja, um /saber-fazerl, pois está de posse de um saber. Um contrato fiduciário ou de fidúcia instaura-se durante o processo de ensino-aprendizagem, sobretudo do ponto de vista do educando que outorga ao seu educador o papel de "sujeito suposto saber", detentor de um saber lingüístico, que ele quer ou necessita, pois constitui-se um sujeito em falta para o mercado de trabalho.

São muitos os motivos pelo qual o educando procura aprender a língua inglesa, seja por uma maior capacitação e formação para conseguir uma 
inserção no mercado de trabalho, por status ou por querer uma ascensão social e profissional em sua empresa, ou, até mesmo, por uma realização pessoal. Todavia, o que move a maioria desses educandos adultos para alcançar o seu objeto de valor é o mercado de trabalho, já que tanto o sujeito enunciador (a empresa ou o mercado de trabalho) quanto o enunciatário (educando) possuem uma visão de mundo apoiada nos recortes culturais (designata) de uma sociedade, num mundo globalizado, em que as negociações estão cada vez mais acirradas e agressivas e que a necessidade de uma linguagem comum faz-se presente para intermediar as negociações. Desse modo, o educando vai em busca desse saber, sua ação aciona o /fazerl de um segundo sujeito educador (S2) que, por sua vez, procura construir um saber e gerar uma competência no seu educando (S1) por meio de uma programação metodológica estabelecida a partir do que ele levantou desde o primeiro contato com seu educando e durante o curso (programas narrativos auxiliares). Contudo, esse educando deverá passar por alguns estágios para conseguir o seu Ov. Assim, as provas glorificantes irão the conferir uma competência e prepará-lo para chegar ao final de seu percurso em posse de seu objeto de valor. Temos, então, os seguintes modelos semióticos das relações actanciais e seus programas narrativos:

\section{Educando (S1)}
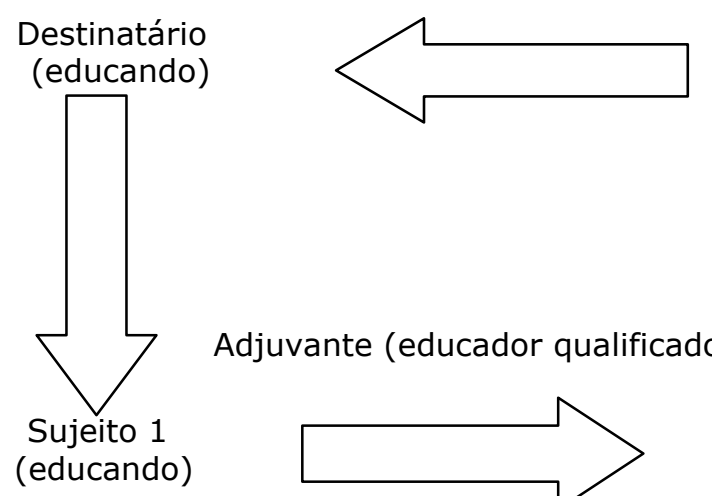

Destinador (educador)

Adjuvante (educador qualificado e sensível, metodologia)

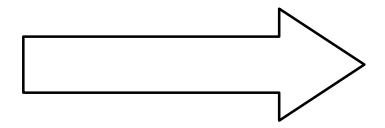

Oponente (docentes não qualificados, metodologias ultrapassadas, cansaço, falta de motivação, falta de tempo, custo) 


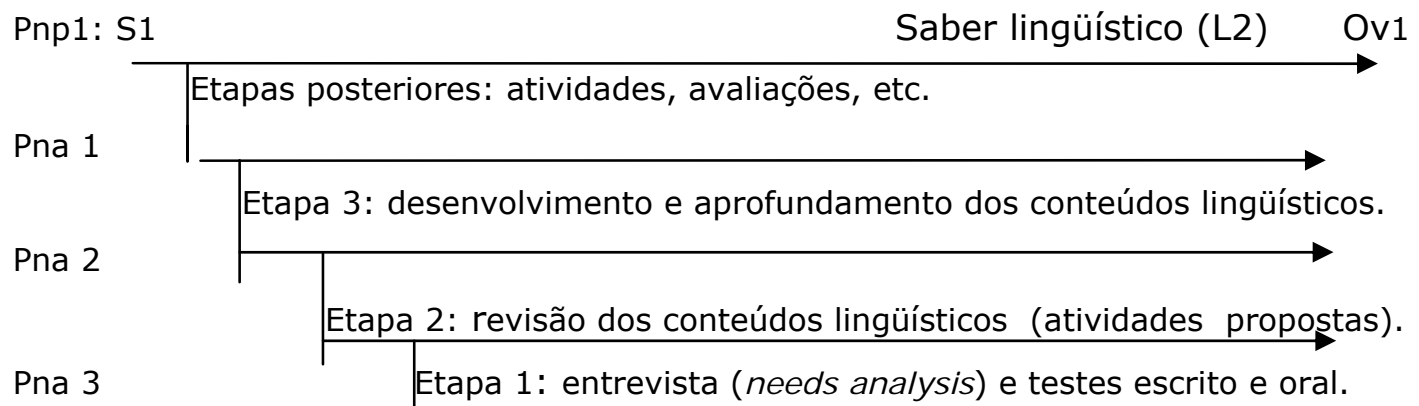

\section{Educador ( S2)}

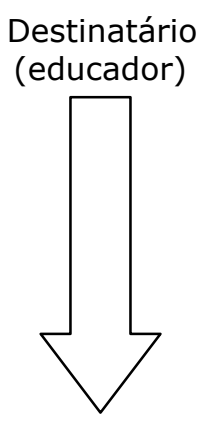

Sujeito 2 (educador)

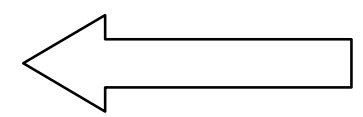

Destinador (educando)

\begin{abstract}
Adjuvante (formação/capacitação, metodologia eficaz, comprometimento do educando no processo de ensinoaprendizagem)
\end{abstract}

Oponente (falta de formação/capacitação, metodologias ultrapassadas falta de informação, falta de comprometimento do educando)

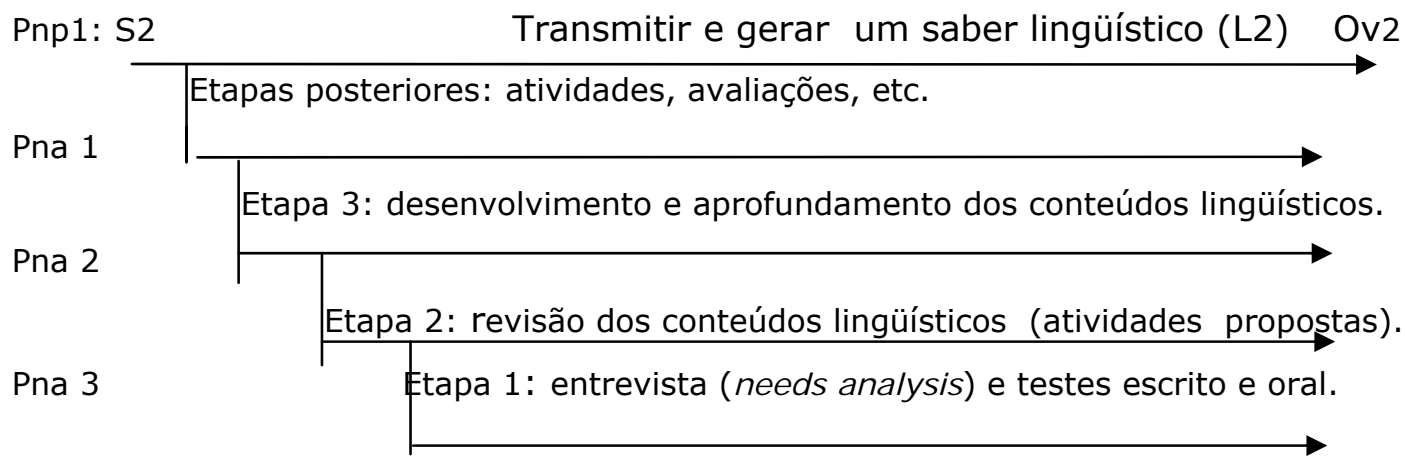


S1 - Educando

S2 - Educador

Ov - Objeto de Valor

L2 - Língua Inglesa

Pnp - Programa Narrativo Principal

Pna - Programa Narrativo Auxiliar

Onde S1 e S2 = Sujeitos Complementares/Destinação Recíproca.

Figura 11: Aspectos das estruturas narrativas nas relações entre destinadores e destinatários e programas narrativos (Educador/Educando)

EN1 (enunciado inicial) $=(S \cap O)-$ Enunciado de estado disjuntivo (no começo do percurso da narrativa).

EN2 (enunciado de transformação $)=(S \mathrm{U} / \cap \mathrm{O})-$ Enunciado de estado conjuntivo ou disjuntivo depende do percurso realizado pelo educando durante o curso.

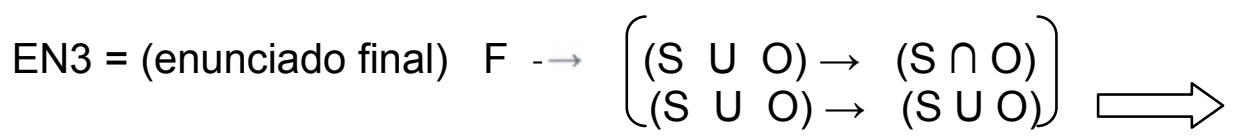

Enunciado da transformação

(Narrativa de vitória)

ou

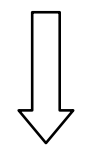

(Narrativa de fracasso)

Num primeiro momento (EN1), o educando não está em conjunção com seu Ov, pois ele irá iniciar seu percurso, que será instaurado a partir do momento que ele investir em seu saber lingüístico (querer/fazer e um dever/fazer). Num segundo momento (EN2), estabelece-se uma transformação que pode estar em conjunção ou disjunção com o Ov, dependendo da maneira que o educando vem trabalhando em seu percurso de aprendizagem. Finalmente, teremos um percurso final (EN3), que mostrará se o percurso feito pelo educando foi fadado ao sucesso ou ao fracasso. 
Temos, portanto, com relação às modalidades de competência o seguinte: o sujeito destinatário, o educando, após ter sido compelido pelo mercado de trabalho a ter de aprender a língua inglesa, busca uma escola de idiomas ou um professor particular, ou seja, um /dever-saberl comunicar-se na L2, mesmo que não queira saber ou não tenha vontade de aprender o idioma, mas precisará para poder comunicar-se com seus clientes nas negociações internacionais ou conseguir um cargo melhor na empresa, ou, ainda, preencher as exigências de um mercado de trabalho globalizado e competitivo. Assim sendo, o sujeito procura, num educador ou numa instituição de ensino, a possibilidade de estabelecer um contrato que possa ser capaz de transmitir e gerar um saber lingüístico nele, fazendo-o ser capaz, ou seja, competente na língua inglesa, desempenhando, desse modo, um requisito importantíssimo no mercado de trabalho e nessa era globalizada: ser capaz de comunicar-se na língua inglesa.

Durante o percurso de aprendizagem, o desempenho do sujeito enunciatário (educando) é avaliado pelo educador (enunciador de um saber lingüístico), assim, o próprio sujeito-aluno poderá mensurar o seu progresso e projetar perspectivas e metas para o futuro. Com o tempo dedicado aos estudos da L2, o indivíduo poderá se considerar qualificado para competir com mais vantagens no mercado de trabalho ou, então, não será qualificado, visto não ter conseguido desempenhar de maneira satisfatória seu percurso de aprendizagem, seja pela falta de tempo, de comprometimento ou vontade de /querer/, realmente, aprender.

A competência lingüística e sociocultural da L2 apenas será possível se houver um envolvimento real do educando nesse processo e um educador que possa transmitir e gerar um saber lingüístico no outro. Então, segundo o que o educando acredita, a instituição de ensino ou um educador delega 
um /saber/ a ele, diante disso, esse educando, ao final de um percurso, deverá /saber-fazer/ e /poder-fazer/ o que antes não dominava, no início de seu percurso narrativo. A competência lingüística dependerá de um bom desempenho nas quatro habilidades (ouvir, falar, ler e escrever), sobremaneira no discurso oral que, provavelmente, será mais requisitado. Nesse sentido, para o educando conseguir a fluência tão almejada, ele deverá /saber-fazer/ bem, se tiver um /querer-fazer/ bem o seu percurso de aquisição de uma nova língua. Ao final do programa, tanto o educador quanto o educando e, até mesmo, a empresa, para qual esse sujeito-aluno trabalha poderão avaliar o seu percurso narrativo, ou seja, se foi fadado ao sucesso ou ao fracasso.

O sujeito enunciador (educador) tem o conhecimento da língua inglesa, um /poder-fazer-saber/ e uma competência no ramo, ou seja, um /podersaber-fazerl, visto que o educador deve ter um discurso pedagógico voltado para a formação, informação e capacitação de um indivíduo. Ao mesmo tempo, o educador possui um discurso persuasivo, que leva o indivíduo a crer na necessidade de fazer um curso de línguas em um mundo globalizado, ditado por regras e visão hegemônica da língua inglesa, pois o mundo dos negócios requer um conhecimento desse idioma, daí a necessidade desse indivíduo procurar um curso de inglês para que ele possa fazer parte do mercado de trabalho, tendo mais oportunidades, prestígio e, até mesmo, uma situação financeira melhor. Diante dessa situação, o indivíduo não se encontra em posição de escolha, mesmo que para isso ele tenha de negar sua vontade e submeter-se a um /deverl e/ou /querer/ do Outro.

O educador tem em mente as necessidades de seu educando e o que deverá fazer para seu educando alcançar o seu Ov (programas narrativos auxiliares) e firma um contrato cooperativo com esse sujeito. Quando S2 diz /poder-fazer/ S1 aprender a L2 é instaurado um simulacro de 
possibilidades ( + prestígio, + status, + dinheiro, + ascensão social, + ascensão profissional). A necessidade de aprender inglês é fato para $\mathrm{S} 1$, e ele sabe que não terá um cargo melhor se não tiver uma certificação na língua inglesa e o mercado de trabalho corrobora para ele pensar dessa forma.

O educando espera do educador uma vocação, um /poder-fazerquerer/ e uma ética profissional /poder-fazer-dever/, assim, é estabelecido um sistema de crenças, um /poder-fazer-crerl, afinal convencer é /fazercrerl e persuadir é /fazer-fazerl. Nesse sentido, S1 espera de S2 (educador), um /poder-fazer-saber/, pois o educando busca uma competência lingüística que o leve a uma possibilidade de inserção no mercado de trabalho. Se o contrato for realmente cumprido por um profissional competente, que analisa as necessidades do educando, bem como suas fragilidades (olhar sensível), e, além disso, um educando que colabore com seu próprio desenvolvimento, teremos ao final dessa trajetória um sujeito que poderá se considerar competente e qualificado para o mercado.

A construção da narrativa de S1 é ir em busca de valores cognitivos e pragmáticos visto que esse curso levará o educando a ter uma competência maior e, conseqüentemente, um bom desempenho na sua vida profissional. Entretanto, o Ov apenas poderá ser alcançado se tanto o educador quanto o educando trabalharem adequadamente em seus percursos. Portanto, a narrativa principal do $\mathrm{S} 1$ só terá êxito se passar pelas etapas de construção do sentido da L2 (programas narrativos auxiliares) durante o processo de ensino-aprendizagem da língua inglesa, qualificando o educando pelo seu desempenho nesse processo, ao final de cada estágio e, com o passar do tempo, do curso. 
O tempo de aprendizagem de uma língua não pode ser medido em dias ou meses, é um processo contínuo. Levamos algum tempo para começar a compreender e pensar em um outro universo lingüístico e cultural, contudo essa aprendizagem nunca se esgota deve ser sempre (re)alimentada. Para chegarmos a um nível confortável de conhecimento da língua inglesa seriam necessárias 1.200 horas segundo alguns estudiosos no ensino dessa língua. Todavia, essas horas só acrescentarão algo ao sujeito-aluno se ele estiver realmente envolvido em seu próprio processo de aprendizagem, pois um lquerer-saberl a L2 depende do próprio sujeito-aluno. Diante disso, o tempo que ele mesmo irá criar para si mesmo e como fará para poder alcançar um conhecimento, ou seja, os esforços empreendidos para conquistar seu Ov serão coadjuvantes na formação desse educando. 


\subsection{Modelo semiótico da competência e capacitação do} Educando no mercado de trabalho

\section{CAPACITAÇÃO/ FORMAÇÃO}

(PRESTÍGIO E COLOCAÇÃO NO MERCADO)
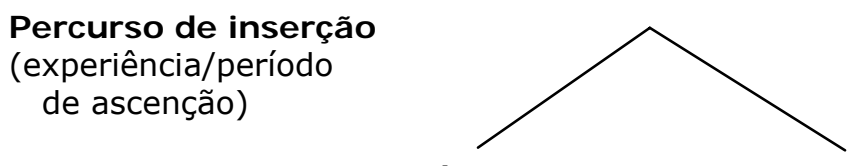

COMPETÊNCI A
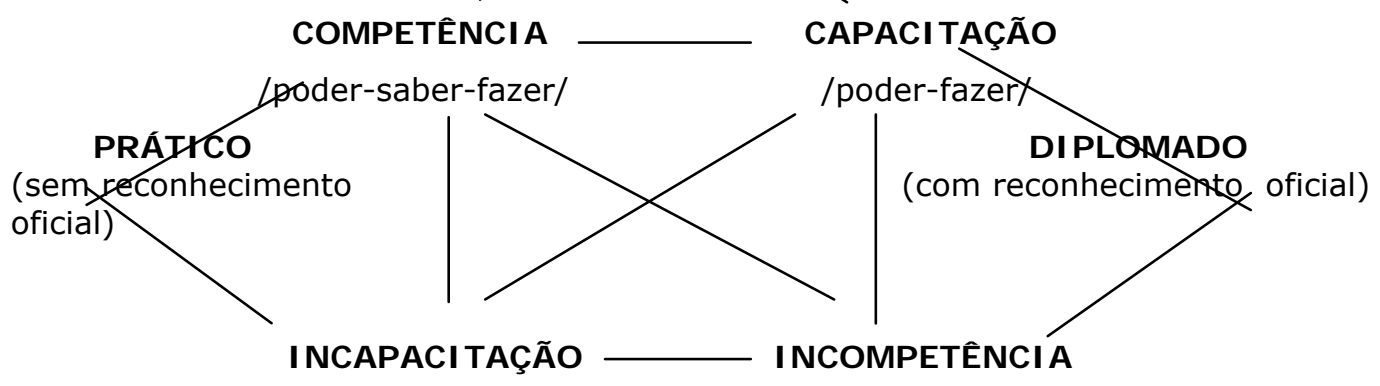

/ñ poder-ñ fazer/ / / / n poder-saber-fazer/

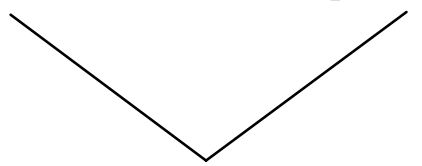

Percurso de exclusão (inexperiente)

$\varnothing$

MARGI NALI DADE

(NÃO CONSEGUIR UM TRABALHO NO MERCADO)

Figura 12: Octógono Semiótico da Competência e Capacitação de S1 no mercado de trabalho

Logo, quando temos capacidade e competência - perante nossa sociedade - teremos prestígio e colocação no mercado (inserção no mercado), contudo não haverá lugar para os que não têm capacidade e são incompetentes, esses estariam na marginalidade (exclusão do mercado). Todavia, existe uma outra situação que é muito comum no 
mercado de trabalho, aquele indivíduo que se graduou, mas não tem experiência e seria incompetente aos olhos do nosso mercado (percurso de exclusão). Finalmente, teríamos aquele indivíduo que o mercado não aceitaria por não ter um diploma, apesar da vasta experiência, bastaria uma capacitação diplomada para que ele tivesse o perfil desejado pelas empresas e, assim, ser inserido no mercado de trabalho (percurso de inserção).

O imediatismo do mercado de trabalho instaura sua própria lógica, a qual não leva em conta o fator humano, pois o indivíduo é apenas um agente econômico que está sob um olhar crítico e ameaçador de seu chefe ou do mercado de trabalho. A aquisição de uma língua demanda tempo, contudo Time is money, e, por causa desse dito popular, o educando sente-se mais ansioso e oprimido por essa lógica de mercado, que é uma lógica competitiva e visa lucros, portanto não pensa no indivíduo. Esse mercado quer resultados, sobretudo quando investe em seu funcionário, o que torna a aprendizagem ainda mais difícil para o educando, que se sente na obrigação de aprender o mais rápido possível, visto que poderá estar em jogo a sua posição na empresa. 


\title{
CAPÍTULO V
}

\section{V - PROPOSTA DE UM MODELO LINGÜÍSTICO-PEDAGÓGICO NO ENSINO DE LÍNGUA INGLESA}

\begin{abstract}
“... uma coisa é a ação educativa de um educador desesperançado e a outra é a prática educativa de um educador que se funde na interdisciplinariedade. $\mathrm{O}$ primeiro nega a essência de sua própria prática enquanto o segundo explicita uma certa opção metodológica e epistemológica. Em outras palavras, aquele contradiz o caráter natural da educação, o último a experiência de um certo ponto de vista."
\end{abstract}

Paulo Freire

O modelo lingüístico-pedagógico que será proposto a seguir é pautado na observação das aulas de ensino de língua inglesa para adultos, tendo como língua materna a língua portuguesa do Brasil.

Do ponto de vista lingüístico, o professor-educador irá gerar em seu aluno-educando um saber de ordem lingüística, ou seja, o saber de uma língua natural que precisará desenvolver quatro habilidades lingüísticas falar/escutar e escrever/ler para que uma comunicação efetiva seja instaurada.

Do ponto de vista pedagógico, o educador propõe-se a construir um discurso que faça o educando ser capaz de compreender uma língua natural, buscando por diferentes métodos e técnicas um /poder-fazerl o outro construir um sentido na língua inglesa, gerando, assim, uma 
competência e uma capacitação no sujeito-aluno para um mercado de trabalho.

Da relação entre os dois pontos de vista, teremos um modelo lingüísticopedagógico que será capaz de dialogar, dentro de uma relação de reciprocidade entre educador e educando durante o processo de ensinoaprendizagem da língua inglesa.

Para tanto, desenvolvemos três etapas:

$1^{a}$ etapa - entrevista (needs analysis) e testes escrito e oral;

$2^{\mathrm{a}}$ etapa - revisão dos conteúdos lingüísticos e exercícios escritos e orais e;

$3^{a}$ etapa - desenvolvimento e aprofundamento dos conteúdos lingüísticos.

Assim posto, primeiramente avaliamos e levantamos alguns aspectos da ordem do saber lingüístico e pessoal do sujeito-aluno chamada de needs analysis (ou análise das necessidades) ${ }^{49}$, sendo realizadas por meio de uma entrevista semi-dirigida. Cabe ressaltar que são feitos dois testes: oral e escrito para que o educador possa avaliar o saber lingüístico do educando. Após a entrevista e a avaliação, o educador estabelece seus objetivos com relação ao curso de língua inglesa, expondo ao educando a maneira com a qual ele deverá lidar com o novo saber lingüístico. Da mesma forma, o novo educando expressa seu objetivo quanto ao idioma, assim, um contrato de fidúcia é estabelecido por ambos os sujeitos envolvidos no processo de ensino-aprendizagem. Nessa primeira etapa, mapeamos o modo de agir e pensar do educando sobre a língua-objeto, assim como seus outros saberes, gostos, crenças e valores que nortearão o educador no planejamento das aulas.

$49 \quad$ Ver apêndice A: Needs Analysis 
A segunda etapa é o início do processo de ensino-aprendizagem. $O$ educador analisa os dados da primeira etapa, as avaliações e a entrevista, e, deste modo, estabelece alguns métodos e técnicas distintas para capacitar o educando a um saber lingüístico. É nesse segundo momento que uma relação entre educador e educando é instaurada, ou seja, uma forma de trabalhar diferenciada tanto com relação ao saber lingüístico quanto na relação com o saber do educando, visto que, anteriormente, o educando poderia estar em conjunção ou disjunção com o papel do educador nessa relação de ensino-aprendizagem e, conseqüentemente, da língua inglesa. Nessa segunda etapa, os contratos são reafirmados e temos como "objetos de valor" a aprendizagem de uma língua para o educando e, para o educador, transmitir e gerar um saber lingüístico. Nesse sentido, os percursos a serem percorridos pelos dois sujeitos do processo de ensino-aprendizagem são importantes, pois é a maneira pela qual esses percursos serão desenvolvidos que teremos uma sanção positiva ou negativa dos "objetos de valor" e, por conseqüência, uma trajetória de sucesso ou fracasso, dependendo da maneira que os sujeitos entram em conjunção ou disjunção com seus objetos.

Ainda nessa etapa, o educador apenas trabalha numa revisão com o educando, partindo das avaliações e do estágio que o educando se encontrava anteriormente. Dessa forma, o educador ainda não adota um livro didático, mas utiliza um material suplementar para preparar o educando adequadamente, sanando dúvidas remanescentes e trabalhando nas necessidades desse educando. Posteriormente, o educador adota um livro didático de acordo com o nível de conhecimento lingüístico do educando. Essa etapa tem a duração de dois ou três meses, dependendo da carga horária do educando e das necessidades encontradas durante o processo de aprendizagem. 
A terceira etapa avalia as anteriores, tanto do ponto de vista do educando quanto do educador, ou seja, é avaliada a performance de ambos até aquele momento, e se esses sujeitos estão cumprindo aqueles objetivos que foram estabelecidos no início do percurso de ensinoaprendizagem. Nessa etapa, o educador adota um livro didático e materiais suplementares, dando prosseguimento ao desenvolvimento lingüístico do educando. Durante esse percurso, as técnicas e métodos variam conforme a necessidade do educando. Cabe ressaltar que, desde o início, o educador tem uma postura sensível ('olhar sensível') às necessidades e dificuldades do educando, tentando apagar aquele mal-estar aludido por alguns educandos na entrevista. Nesse sentido, o objetivo do educador é propiciar um outro olhar sobre o processo de ensino-aprendizagem que se estabelece entre educador e educando.

Diante disso, esse modelo propõe-se a mostrar dois aspectos dos sujeitos envolvidos no processo de ensino-aprendizagem:

1. Os percursos de dois interlocutores - o papel do educador e do educando, trabalhando conjuntamente numa relação de ensinoaprendizagem da língua inglesa e;

2. A construção de um saber lingüístico, analisado por meio de um fazer pragmático do educando e de um modo de ensinar do educador, que levam o sujeito-aluno a construir um sentido para a língua inglesa.

Considerando o primeiro aspecto desse modelo, podemos observar o quanto a relação que se estabelece entre educador e educando é importante para a construção de um novo saber lingüístico, sendo que o educador auxilia o educando em seu percurso, propiciando meios para que ele desenvolva um saber na L2. Contudo, para que esse desenvolvimento 
lingüístico ocorra, o educando precisa comprometer-se com o seu processo de aprendizagem. Para tanto, deve cumprir algumas tarefas que são necessárias no desenvolvimento de seu processo de aprendizagem se ele tiver o intuito de conquistar o seu Ov.

Durante o processo de ensino-aprendizagem, o fator psicológico do discente é considerado, visto interferir na aprendizagem desse adulto; quanto mais resistente for o adulto, mais difícil será convencê-lo da possibilidade de aprendizagem da nova língua e a confiar, novamente, no papel de um professor-educador devido àqueles velhos simulacros instaurados anteriormente. Dessa forma, o educador precisa apagar esses simulacros e construir novos por meio de suas atitudes e comportamento nesse processo. Diante disso, ele conquista a confiança do educando, levando-o a ter uma outra postura também. Tanto as atitudes quanto $o$ comportamento do educador refletem na ação do discente e acabam por motivá-lo a ir em busca de seu Ov.

Quanto ao segundo aspecto, tanto os fatores sociocultural e histórico do indivíduo quanto o lingüístico são estudados, visto que esse educando possui algum conhecimento da L2. Diante disso, o educador tem sempre em mente o que foi observado na primeira e na segunda etapa e continua analisando o desenvolvimento lingüístico do educando, já que a aprendizagem é um processo contínuo (on going process). Assim, poderemos mensurar o desempenho do sujeito-aluno por meio de seus discursos falado e escrito comparados aos anteriores. Por essa razão, foram guardados tanto os documentos escritos (tarefas e avaliações) quanto as gravações do discurso oral do educando, bem como as observações do educador sobre as necessidades e dificuldades do sujeitoaluno. 
Após a análise dos dados, o educador deve estabelecer algumas metas no percurso do educando e pensar em abordagens diferenciadas para as quatro habilidades lingüísticas: speaking, listening, writing $e$ reading. Essas habilidades são necessárias para a competência lingüística do educando, assim ele poderá comunicar-se de forma eficiente. Portanto, - educando deve ser capaz de perceber os sons (discriminação auditiva/decodificação da mensagem) e emitir esses mesmos sons (articulação $=$ fala/codificação da mensagem), além de saber escrever os signos lingüísticos (expressão escrita/codificação) e ler os mesmos signos (decodificação da expressão escrita), visto que o sujeito-aluno ora estará se comunicando por meio de um discurso oral, ora estará utilizando um discurso escrito.

Diante desse quadro, o educador necessita de elementos metodológicos que amparem seu discurso pedagógico para que a construção de um saber lingüístico seja instaurada. Sendo assim, são utilizados os 'elementos correlatos' que são relevantes na mediação da aprendizagem (música, filme, CD-roms, jogos, atividades de e-basiclearning, role play, dentre outros), pois facilitam a aprendizagem da L2, auxiliando a construir um sentido. Além disso, o educador deve considerar o primeiro dia de aula, ou seja, a entrevista com o educando ( $1^{\text {a }}$ etapa), tendo em mente seu perfil, seus gostos, experiências, objetivos, etc., visto serem aspectos importantes para o planejamento de aulas do educador. Quando o educando visualiza ou aprende com uma aula mais dinâmica por meio de ações simuladas ou situações reais, a aprendizagem torna-se mais clara, divertida e fácil.

Para que o novo código lingüístico seja estruturado, é necessário que o educando faça exercícios nas quatro habilidades citadas anteriormente. Com relação aos exercícios orais/escritos, o educador conscientiza o educando das diferenças dos segmentos fônicos e seus segmentos 
gráficos na L2. Além disso, o educando deve manter mais contato com a língua estudada, pois o sistema lingüístico da L2 precisa ser continuamente alimentando e realimentando para que haja uma amplificação e manutenção do saber lingüístico. Para tanto, o educando utiliza materiais diversos, como por exemplo, livros, filmes, músicas, a internet, entre outros; esses meios vinculam idéias ou conceitos associados a situações diferentes e contextos, o que torna a aprendizagem mais eficaz e rápida.

Durante as aulas, o educador deve apenas utilizar a língua inglesa para que o educando comece a acostumar-se com o novo código lingüístico e , assim, a construção de sentido será otimizada mais rapidamente pelo educando. Além disso, o discurso oral é sempre incentivado pelo educador, porém durante o desenvolvimento desse discurso, o educador precisa intervir e corrigir as estruturas lingüísticas incorretas para que não ocorra o processo de fossilização. Além disso, é necessário que o educador faça revisões, de tempos em tempos, para que o educando recorde as estruturas lingüísticas ou vocábulos já estudados e, dessa forma, o educador poderá agregar outros elementos lingüísticos por meio de leituras e textos dados em sala de aula ou como tarefa. A participação do educand durante a aula e em seu próprio processo de aquisição é um dado importante, quanto mais dinâmica for a aula e maior for a participação do educando na aula, mais rápido ele constrói um sentido para a língua.

Quando o educando utiliza a L1 na aula, o procedimento adotado é verter para a L2 a mesma sentença e, logo em seguida, pedir para ele repetir na L2 a mesma frase. Com o passar do tempo, o educando perde a resistência, o medo ou a vergonha de expressar-se na língua inglesa e passa a usá-la durante as aulas. Com o aumento de seu repertório lingüístico, ou seja, do léxico e de construções sintáticas, semânticas, morfológicas e fonológicas, o educando participa mais da aula, produzindo 
pequenos discursos tanto orais quanto escritos que aumentam ao longo do curso, pois ele adquire mais confiança no seu repertório lingüístico, que se consolida com o tempo de estudo e dedicação.

As leituras complementares auxiliam na ampliação lexical e semântica de um mesmo vocábulo, visto que o hábito de ler ajuda a escrever e a pensar, conseqüentemente, expressar-se melhor, além de manter atualizados os conteúdos lingüísticos aprendidos anteriormente; nesse sentido, os educandos que lêem mais têm a expressão oral e escrita amplificada.

Foi estabelecido um procedimento a ser seguido pelo educando, que deveria não apenas ler, mas ser capaz de recontar por escrito e oralmente um artigo ou a leitura de um livro escolhido por ele. Dessa forma, o educador pode mensurar a compreensão textual de seu educando. Os erros levantados e as dificuldades são discutidos e o educando faz exercícios a partir desses erros ou dificuldades encontradas na produção oral ou escrita. Esse procedimento propicia ao educando uma segurança maior no discurso oral e escrito da L2.

Vejamos o procedimento de leitura que foi pedido ao educando durante o curso:

- Leitura de um livro no nível lingüístico do educando: O tema foi escolhido pelo educando e demos um prazo de um mês ou menos para que ele apresentasse uma parte escrita e a outra oral. Sendo que, na expressão escrita, ele teria de entregar um resumo do livro e entregar a ficha de leitura ${ }^{50}$, com especial atenção ao universo lexical e, após a leitura, fazer uma apresentação sobre o que foi lido. O feedback da expressão oral foi dado logo após a apresentação do educando sobre o livro. Foram feitas anotações dos erros e

$50 \quad$ Ver apêndice C: Vocabulary Sheet 
observadas as dificuldades. Depois, foram aplicados exercícios para corrigir esses erros e sedimentar algumas estruturas lingüísticas (exercícios do livro de gramática). Entretanto, o feedback da expressão escrita seria discutido somente na aula seguinte, pois devíamos corrigir $\mathrm{o}$ resumo e levantar as dificuldades $\mathrm{e}$ necessidades do educando para, posteriormente, aplicar alguns exercícios.

- Leitura de pequenos textos e/ou artigos em sala de aula: é proposto a leitura de um texto e, após essa leitura, são discutidos o vocabulário e pedimos a verificação do vocábulo desconhecido no dicionário (bilíngüe e/ou monolíngüe). Diante disso, discutimos sobre o léxico e frases que ele não tenha entendido e, após esse procedimento, o educando reconta o texto lido. Da mesma forma, anotamos os erros e dificuldades ou gravamos o educando e, posteriormente, são discutidos e aplicados alguns exercícios enfocados nos erros ou necessidades apresentadas pelo sujeitoaluno durante seu discurso oral. Algumas vezes, durante a expressão oral, são feitas perguntas, além de trabalharmos com as estruturas lexicais, morfológicas e sintáticas retiradas do mesmo texto. O vocabulário desconhecido é explicado e pedimos ao educando para construir frases (oralmente ou por escrito).

O léxico também é trabalhado em situações distintas para que o educando tenha a oportunidade de compreender e ampliar o campo semântico de uma mesma palavra. Nesse tipo de atividade, o educador trabalha com os dicionários, monolíngüe e bilíngüe, que auxiliam o educando a compreender o sentido da palavra pesquisada. Além disso, são retirados alguns parágrafos dos artigos selecionados pelo educador para explicar tópicos gramaticais, ou seja, a gramática é repensada em função do texto que a L2 nos apresenta. Nesses trechos, são realizadas 
perguntas de ordem lingüística para o educando como, por exemplo, se ele poderia explicar o motivo pelo qual foi usado aquele tempo verbal ou preposição, dentre outras questões. Essa foi a estratégia adotada para trabalhar com a compreensão textual visto que queríamos nos certificar se o educando lembrava das estruturas lingüísticas estudadas durante o curso ou para verificar se ele já havia adquirido consciência de uma determinada estrutura lingüística ou lexical que costumava errar.

A tradução de textos variados foi um procedimento utilizado para avaliar o entendimento do educando. Nesse sentido, foi pedido ao educando a tradução de algumas partes do texto, sobretudo expressões ou palavras que o educando tinha dificuldade para lembrar ou precisaria ser mais cuidadoso como, por exemplo, os falsos cognatos, phrasal verbs, expressões idiomáticas ou verbos e vocábulos com sentidos variados dentro de um mesmo texto.

Durante as aulas, o educando comete alguns erros quando se expressa verbalmente, assim, foram adotados alguns procedimentos de correção como, por exemplo, interromper o educando durante a produção oral ou anotar os erros e discutir com ele, ou ainda gravar o sujeito-aluno e, logo em seguida, ele escuta sua gravação e tenta corrigir sua fala. Esse exercício avalia o conhecimento lingüístico do educando sobre a L2. De tempos em tempos, são aplicados exercícios que contenham erros nas frases e o educando poderá corrigir e explicar a sua correção ao educador.

Devemos salientar que o princípio de uma construção de sentido é instaurada, primeiramente dentro de uma relação binária, educador e educando, em que ambos os sujeitos se empenham para atingir sua metas e o contrato firmado no início dessa relação será promovido pelo dialogismo entre eles. Em segundo lugar, essa construção de sentido apenas fará sentido se houver uma transformação de estados do sujeitoaluno para conseguir seu Ov. A maneira que o educador transmite 0 
conteúdo de seu objeto lingüístico é relevante nesse processo de construção de sentido, sem o qual pouco ou nada ajudará o educando a construir seu próprio percurso. Como já havíamos dito, um sujeito-aluno fará um percurso melhor se ele for dotado de algumas das competências modais (querer, dever, saber e poder) para que ele possa executar um Ifazerl. A competência modal só poderá ser operada e transformada se o educando permitir a sua própria transformação. 


\section{CONCLUSÃO}

Esta Tese pretendeu ser um instrumental pedagógico aos educadores de língua inglesa, propondo não somente um olhar diferenciado do que existe no mercado do ensino de línguas para adultos, mas também uma leitura do discurso pedagógico no processo de ensino-aprendizagem. Dessa forma, propusemo-nos a observar a lógica de conceptualização do outro (educando), a maneira que ele constrói um novo saber. Esse olhar é voltado ao sujeito cognitivo do sujeito-aluno dentro de uma relação de reciprocidade entre educador e educando, sendo que aquele possui um /saber-fazer/ de um discurso pedagógico, que pode e deve /fazer/ diferença na maneira de ensinar a língua inglesa. Nesse sentido, consideramos um 'olhar mais sensível' e analítico do professor-educador num processo de ensino-aprendizagem, além de despertar no aluno-educando um /fazerl mais consciente e participativo em seu processo de aquisição de um saber lingüístico.

Assim, analisamos o processo de aquisição de uma língua, tendo como atores desse processo, o educador e o educando. Para tanto, buscamos na semiótica Greimasiana a construção do sentido nesse processo de ensino-aprendizagem, analisando os percursos narrativos dos sujeitos envolvidos. Além disso, agregamos a essa análise alguns conceitos da psicanálise Lacaniana para que houvesse a possibilidade de compreender o aspecto psicológico de um indivíduo, de quem o educador precisa estar consciente para saber como lidar com o processo de aprendizagem do educando, respeitando o tempo desse outro e a maneira dele lidar com seu Ov. Essa forma de agir do educador acabará evitando o mal-estar aludido pelo educando no início de seu percurso ou, até mesmo, outros sintomas 
que acabam levando ao afastamento de seu objeto de valor, ou seja, a língua inglesa.

Quando falamos em ensino-aprendizagem vêm-nos à mente as figuras de dois atores: o papel do professor-educador e do aluno-educando nesse processo. Assim, a troca estabelecida entre esses sujeitos será de grande valia para o processo de ensino-aprendizagem. O êxito de um saber compartilhado só será possível quando ambas as partes cumprirem os seus papéis pautados nos contratos firmados para a obtenção de seus objetos de valor, que são estabelecidos desde o início do processo e vão se transformando com o passar do tempo (on going process). O sujeitoaluno que, inicialmente, está em disjunção com o seu objeto de valor, passará a uma conjunção, mas para que isso seja possível, a maneira pela qual o educador transmite um saber terá de ser muito bem planejada, com vistas às necessidades reais do mundo em que estamos inseridos e ao universo sócio-lingüístico-histórico e cultural do educando.

Ao professor-educador cabe observar essa lógica de significação no outro, utilizando-se da semiótica discursiva para auxiliar nessa trajetória de perceber e /saber-fazerl o outro produzir mesmo que o sentido geral desse outro escape-nos, sobretudo na maneira como recorta o mundo e o reelabora. A impossibilidade de captar o todo é fato, mas as estruturas narrativas e modais que sustentam o discurso produzido pelo educando estarão sempre nos mecanismos de comunicação desse ser humano, auto-regulando-se e auto-alimentando em suas relações com o mundo, com o que o cerca, produzindo sentidos e significações sobre seus valores e visão epistêmica de um mundo semioticamente construído.

O educador deverá preocupar-se em fazer com que o seu educando compreenda a L2 de forma agradável e envolvente, bem como ter conhecimento de materiais didáticos diversos que amparem o discurso pedagógico, fazendo que o educando construa um sentido para o novo 
saber lingüístico. Diante disso, comentamos sobre a necessidade de o educador considerar 0 processo de comunicação (processo onomasiológico e semasiológico) que ocorre numa relação entre educador e educando durante a transmissão e constituição de um saber lingüístico.

A experiência de aprender uma nova língua não precisa ser árdua, mas deve ser trabalhada conscientemente. O papel do educando é tão importante quanto o do educador visto que o educando precisa se comprometer com seu próprio processo de aprendizagem e, em contrapartida, o educador ampara esse processo, trabalhando conjuntamente com seu educando e fazendo que ele encontre meios de expressar-se cada vez melhor, provendo-lhe de autonomia para que continue, por si mesmo, em seu processo de aprendizagem. Assim, o educador deve sempre analisar seu papel nessa relação de ensinoaprendizagem e prestar atenção na forma que o outro constrói um saber lingüístico.

Os estudos lingüísticos e os cursos ou palestras sobre o ensino de idiomas serão imprescindíveis, durante e após a formação do educador, para que haja uma compreensão amplificada do processo de ensinoaprendizagem. Diante disso, o educador torna-se mais competente, sendo capaz de transmitir um saber ao outro e, assim, tornar o sujeito-aluno apto a desempenhar esse saber lingüístico no seu dia-a-dia.

Portanto, podemos dizer que a práxis educativa é um elemento importante para o desenvolvimento e formação de um bom profissional; quanto mais consciente for 0 educador do processo de ensinoaprendizagem, mais competente ele será, colocando em prática tudo o que vem aprendendo ou foi aprendido por meio de cursos ou leituras, podendo aplicar, conscientemente, as novas informações; todavia, o educador sempre estará pensando para quem se destina esse saber, adequando 
teorias, métodos e técnicas às necessidades individuais de cada sujeitoaluno.

Nesse sentido, propusemos um modelo lingüístico-pedagógico que pudesse viabilizar um percurso de aprendizagem mais adequado às necessidades do sujeito-aluno, visando sobretudo fazê-lo acreditar ser possível a construção de sentido de um outro universo lingüístico sem causar perplexidade diante do novo e distanciamento do seu Ov. Contudo, para que a proposta de um modelo lingüístico e pedagógico no ensino de língua inglesa seja viável, precisamos de um educador consciente do processo de ensino-aprendizagem e das interferências da L1, com especial atenção às dificuldades encontradas anteriormente pelo sujeito-aluno nesse processo, buscando compreender o que reverberou de negativo no inconsciente desse sujeito-aluno, e levou-o a criar barreiras, colocando-se como anti-sujeito em sua própria relação com a L2. Assim, dividimos esse modelo em 3 etapas:

$1^{\text {a }}$ etapa - entrevista (needs analysis), testes oral e escrito;

$2^{a}$ etapa - revisão dos conteúdos lingüísticos e exercícios escritos e orais; e $3^{a}$ etapa - desenvolvimento e aprofundamento dos conteúdos lingüísticos.

O educador que detém um saber e possui como Ov a transmissão de um saber lingüístico precisará avaliá-lo, em um primeiro momento, por meio de uma entrevista ( $1^{\text {a }}$ etapa), na qual teremos o perfil de nosso educando, analisando gostos, necessidades e objetivos, observando sobretudo o lado psicológico (relação entre o educando e a língua inglesa/educador) do discente. Além disso, na $1^{\text {a }}$ etapa, levantamos um histórico lingüístico por meio de uma avaliação escrita e oral. Esse sujeito busca como Ov o conhecimento de uma língua estrangeira para poder adaptar-se e inserir-se num mercado de trabalho, mesmo que isso não seja 
seu desejo inicial, mas a necessidade obriga-o e impulsiona esse indivíduo a ir em busca desse Ov.

Essa obrigatoriedade irá mostrar a forma pela qual o educando lida com a L2, entretanto haverá experiências anteriores com a aprendizagem da língua e teremos um indivíduo receoso em fracassar novamente, visto que, no passado, ele não conseguiu aprender, levando-o a construir bloqueios e, assim, qualquer tentativa de aprender o "novo". Apenas com muita paciência tanto do educador quanto do educando e de um comprometimento com o Ov é que o discente poderá ir ao encontro do saber lingüístico; fazendo um bom percurso, conseguirá chegar a uma sanção positiva e, finalmente, estará em conjunção com seu Ov.

$\mathrm{Na} 2^{\mathrm{a}}$ etapa, é realizada uma revisão das estruturas lingüísticas da L2 por meio de um material didático rico e variado, partindo do que 0 educando já estudou no passado, mesmo aquele indivíduo que tenha tido apenas o nível elementar na sua aprendizagem. Nessa fase, podemos detectar o que realmente foi aprendido pelo educando e quais as falhas e/ou lacunas que passaram despercebidas por avaliações anteriores. Além das estruturas gramaticais e lexicais, que são revisadas, a percepção auditiva do sujeito-aluno também é trabalhada para que ele adquira um pouco mais de conhecimento sobre os sons e tenha a oportunidade de reconhecer e distinguir novamente esses mesmos sons, bem como aprender outros. Após a revisão, elaboramos um material didático adequado às necessidades desse educando e outros materiais de seu interesse e, dessa forma, podemos discorrer melhor no processo de transmissão da língua inglesa.

$\mathrm{Na} 3^{\mathrm{a}}$ e última etapa, temos o desenvolvimento da L2 propriamente dito a partir do que foi levantado nas duas primeiras. É nessa etapa que podemos saber, de fato, o nível ou estágio de aprendizagem adequado ao desenvolvimento lingüístico do educando e poderemos prosseguir nele, 
sem que haja problemas que não foram bem resolvidos em estágios anteriores de sua aquisição lingüística da L2. A variedade de técnicas e métodos durante o processo de aprendizagem auxilia a formar um indivíduo muito mais preparado, eficiente e observador, com um desempenho lingüístico mais amplificado e apurado.

Durante o desenvolvimento desta pesquisa, comentamos sobre a necessidade de trabalhar com o educando as quatro habilidades (four skills) que levam a uma fluência na L2, a saber: expressão escrita, expressão oral, a percepção auditiva e a leitura para que o sujeito-aluno pudesse atender às necessidades de um mercado globalizado e muito competitivo. Cada uma dessas habilidades foi comentada e discutida por meio de métodos e técnicas diversificados para trabalhar com o educando. Para tanto, utilizamos os 'elementos correlatos' que foram importantes para o desenvolvimento lingüístico do idioma, visto serem elementos que amparavam uma explicação e, dessa maneira, ajudavam numa imagem mental do que estava sendo explicado, pois funcionavam como elementos mnemônicos de uma idéia, situação ou vocábulo.

Ainda durante o desenvolvimento desta Tese, percebemos que o educando se mostrava resistente em aprender a L2 devido a experiências desagradáveis do passado e/ou por Inão-querer/ aprender a língua, mas /dever-saberl para conseguir uma colocação no mercado de trabalho. Tendo esses sintomas em mente, trabalhamos a motivação e auto-estima do educando, procurando trabalhar de forma mais personalizada e sensível àqueles problemas aludidos por ele em sua entrevista com a finalidade de transformar o modo de pensar do sujeito e fazê-lo lidar de outra forma com sua aprendizagem, levando-o a desconstruir velhos simulacros e construir novos no que diz respeito ao papel do docente e sua relação com o novo saber lingüístico, dotando-o de um olhar mais amplo a respeito da 
necessidade de aprender a L2 e que não ficasse restrito apenas ao seu objeto de valor.

Acompanhamos o desenvolvimento lingüístico dos educandos durante 5 anos, tanto daqueles que seguiram todas as orientações pedidas quanto daqueles que racionalizavam desculpas para o seu não envolvimento com a língua ou a falta de tempo para estudar. Assim, obtiveram um melhor desempenho lingüístico na fala e na escrita aqueles educandos que, realmente, empenharam-se em seus estudos lingüísticos. Durante 0 processo, esses educandos perceberam que quanto maior fosse seu empenho em fazer o que era pedido e/ou sugerido, maior e mais rápido seria seu desenvolvimento cognitivo da língua, o que acabou por motivar o educando a continuar investindo em seu próprio processo de aprendizagem na sala de aula e, sobretudo, fora dela.

Diante desse quadro, pudemos responder a algumas questões levantadas durante o processo de elaboração dessa Tese. Uma delas foi a questão do papel do docente no processo de ensino-aprendizagem. Este precisa ter um discurso que construa um saber sem causar perplexidade no outro, ou seja, um discurso que respeite os limites do pequeno outro. Com toda certeza, o discurso do Grande Outro influencia nos hábitos do educando e o faz /querer/ ir em busca de mais informação ou o afasta de seu Ov. A outra questão levantada foi o papel do discente que também precisa /querer-saber/ e implicar-se mais nesse processo para que possa entrar em conjunção com seu Ov e, assim, conseguir se comunicar na L2; sem a participação ativa do educando seria impossível o desenvolvimento de um novo saber lingüístico.

Por conseguinte, somente um professor que escolha ser um educador no sentido que essa palavra traz consigo poderá fazer o outro pensar e agir diferente diante de uma saber. Por outro lado, a demanda vem desse outro 
que, também, precisa /querer-saber/ mais do que simplesmente /deversaberl, visto que aprenderá mais rapidamente quanto maior for seu desejo de aprender o novo saber lingüístico. Ambos os sujeitos estão em uma relação de reciprocidade e o trabalho de um interfere no trabalho do outro e todos ganham nesse processo, ou seja, um terá a possibilidade de adquirir uma competência e o Outro em ter podido gerar essa mesma competência - um novo saber - contribuindo na formação cultural e social do indivíduo para que ele tenha condições de lidar com o novo saber lingüístico, com uma nova forma de ler e construir um sentido em uma outra cultura.

Consideramos, também, a metodologia adotada nesse processo de ensino-aprendizagem da L2 e concluímos que tanto os métodos quanto as técnicas empregadas deveriam ser adequadas não só a cada educando, mas ao mundo em que estamos inseridos, visto que o sujeito-aluno possui necessidades específicas e o educador disponibiliza toda uma gama de novos materiais que podem ajudar no desenvolvimento lingüístico. Além disso, a diversidade de métodos e técnicas aplicadas às aulas permitem amplificar o conhecimento do educando, capacitando-o a um melhor desempenho com relação à língua inglesa, levando-o a estudá-la de formas diferentes e com maior propriedade. Podemos, assim, pensar em desenvolver outras idéias e agregar fatos novos às bases teóricas, já que o processo de ensino-aprendizagem está sempre se modificando devido a sua natureza movediça e às experiências observadas nos educandos.

Nessas circunstâncias, a forma de trabalhar com o educando deveria ser diferente, uma vez que partimos das experiências vividas por ele, assim sendo, o educando é a exata medida para podermos avançar no ensino da L2 ou retardar esse ensino quando necessário. O universo históricolingüístico-social e cultural do educando não deve ser desprezado, pois será possível levantar dados para o desenvolvimento de um percurso mais sensível às necessidades dele, facilitando, assim, a aquisição da L2. 
Nesta Tese, foram levantados os erros e dificuldades mais comuns do educando brasileiro que ocorrem no início de sua aprendizagem ou durante o processo de aquisição. Geralmente, esses problemas ocorriam pela interferência de um outro sistema lingüístico, nesse caso em particular, a língua portuguesa do Brasil. Contudo, os problemas ou dificuldades do educando foram resolvidos com exercícios específicos e atividades diversificadas dentro da sala de aula e fora dela. Diante das dificuldades encontradas pelo educando durante o seu processo de aprendizagem da L2, procuramos estratégias didáticas diversas que facilitassem a sua aprendizagem. O educador está sempre criando e desenvolvendo condições que levem o educando a aprender mais sobre a L2. A partir das condições que foram criadas e desenvolvidas pelo educador, serão estabelecidas metas para o educando, fazendo-o relembrar de seu objetivo inicial nos momentos de desânimo.

Quanto às estratégias didáticas, utilizamos os 'elementos correlatos' para que houvesse uma assimilação mais rápida dos novos signos lingüísticos. Assim, procuramos trabalhar três tipos de 'elementos correlatos': as imagens, sejam elas por meio de um vídeo ou de figuras (flash cards); as situações dramatizadas (role play) ou simulação de casos reais (simulation), abordando temas variados, situações do cotidiano e/ou de negócios; e o conhecimento do educando em outras semióticas-objeto que são comparadas às situações na $L 2$, ou seja, experiências que 0 educando já tenha vivido, as quais são comparadas e transpostas às situações de aprendizagem.

Sendo assim, quanto mais elaborada e desenvolvida forem as estratégicas metodológicas do educador, maior será a compreensão da L2 pelo educando. Com o tempo, o discurso do sujeito-aluno tornar-se-á mais claro e irá expandir-se cada vez mais, dependendo do tempo que ele se 
dispõe a estudar a L2 em seu percurso individual. Diante disso, a língua será estruturada e acabará por instaurar-se no discurso falado e escrito do educando, levando-o ao processo comunicacional pretendido.

O educador, por meio de seu discurso pedagógico, sugere procedimentos de estudo, levando o educando a criar algumas rotinas em seu processo de aprendizagem, ou seja, fazendo-o perceber a relevância de manter um contato com a L2, seja por meio de filmes, músicas ou internet, não só pelos exercícios e leituras que são solicitados durante o curso. Com o tempo, o próprio educando cria novos hábitos de estudo que amplificarão sua aprendizagem. Contudo, o educador não pode esquecer de explicar de forma clara a razão para algumas técnicas e exercícios que são desenvolvidos para o educando. Além disso, tanto as técnicas quanto os exercícios são sempre contextualizados, envolvendo atividades mais comunicativas e interativas nas situações propostas em sala de aula.

O discurso do Grande Outro, o interlocutor de um saber lingüístico, irá legitimar, ao pequeno outro, um lugar social que antes não existia. É esperado daquela alteridade um /poder-fazerl esse outro /saber-fazerl e esse saber autoriza o pequeno outro, ou seja, o interlocutário da nova língua, a um /saber-poder-fazerl, levando-o a uma comunicação em outro código lingüístico que ainda não é competente. No entanto, essa comunicação será efetivada com a orientação de um educador-interlocutor da L2. Esse grande Outro, que é uma figura de poder, detentor de um "saber", poderá construir ou destruir a motivação do sujeito-aluno e a autoestima do mesmo. É esse discurso que constrói um ensino melhor e eficaz ou o destrói e mantém o discente afastado de seu Ov, provocando um malestar.

Concluímos, assim, que o processo de ensino-aprendizagem de uma língua estrangeira requer rigor e comprometimento do educador e do 
educando, uma participação ativa nesse processo. Ambos trabalham conjuntamente para alcançarem seu Ov. Assim, a construção de sentido de uma língua passará a ter um significado para aquele outro, que carrega consigo toda sorte de bloqueios, dificuldades e receios e precisam ser respeitados pelo educador por meio de um 'olhar sensível'.

É uma proposta possível e vem mostrando-se eficaz, com ótimos resultados. Certamente esse modelo sofrerá mudanças ao longo do tempo, agregando outros conceitos metodológicos devido às pesquisas de ensino de línguas e ao perfil de indivíduos que, eventualmente, terão necessidades outras. Contudo, se o educador estiver sempre disposto a aprender com as novas tecnologias, com as novas propostas de métodos e técnicas, além de observar e analisar o perfil dos novos educandos, as aulas serão melhores, mais dinâmicas e, sobretudo, condizentes a uma realidade que será instaurada num determinado momento, adequando-se a um novo indivíduo e aproximando-o de seu "objeto de valor".

Ensinar é antes de tudo um ato ativo e criativo, de comunicabilidade, uma relação de reciprocidade entre educador e educando. Educar implica mais do que transmitir um saber, está além disso. Existe um comprometimento de todos os sujeitos envolvidos no processo de ensinoaprendizagem. Tanto o educando quanto o educador são sujeitos que se constituem pela falta, assim sendo, sempre haverá mais a aprender. $\mathrm{O}$ processo de aprendizagem não se esgota e o de ensinar também não. Nesse quadro de incompletude, tecemos relações com o saber que nos levam a outras e depois a outras e, assim, ad infinitum.

Não é tarefa fácil, mas possível tanto para o educador que se propõe a fazer o outro construir um novo saber lingüístico quanto para aquele educando que, realmente, quer aprender a se comunicar por meio de um outro universo lingüístico. Por conseguinte, esse conhecimento não só o 
levará a uma inserção no mercado de trabalho, mas também abrirá a possibilidade de compreender um outro universo lingüístico, ampliando sua visão de mundo e possibilitando, assim, o acesso a outras áreas de conhecimento na língua inglesa

We shall not cease from exploration... And the end of all our exploring Will be to arrive where we started And know the place for the first time.

T.S Eliot "Little Gidding” 


\section{REFERÊNCIAS}

AMOSSY, R (org.). Imagens de si no discurso - A construção do Ethos. São Paulo : Contexto, 2005.

ANDRADE, M. M DE. Como preparar trabalhos para cursos de pósgraduação. Noções práticas. 5. ed. São Paulo: Atlas, 2002.

AZANHA, J.M.P. "Uma reflexão sobre a didática". In: Educação: Alguns escritos. São Paulo: Nacional, 1987, p. 70-7.

BACHA, M. N. A arte de formar- O feminino, o infantil e o epistemológico. Petrópolis: Vozes, 2002.

BAKER, A. Ship or Sheep? An intermediate pronunciation course. New Edition. Cambridge : University Press, 2002.

BARBOSA, M.A. "Da constituição e transmissão do saber lexical: Um modelo lingüístico Pedagógico". In: Revista Brasileira de Lingüística, Vol. 7, no 1, Ano 7. 1984, p. 83-103.

. "O percurso da enunciação, a relação de equivalência lexical e ensino do léxico". In: Estudos lingüísticos XXI. Anais de seminários do GEL. Vol. 1. GEL/Fundação Educacional, 1992, p. 258-265.

. "Relações de significação nas unidades lexicais". In: Anais do

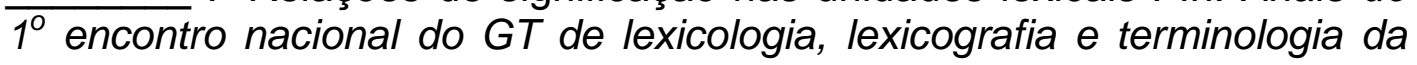
ANPOLL (faculdade de letras/UFRJ ), 1997.

BARROS, D. L. de. Teoria do Discurso - Fundamentos Semióticos. 3. ed. São Paulo: Humanitas, 2002.

BEIVIDAS, W. Inconsciente et Verbum. São Paulo: Humanitas, 2000.

BENVENISTE, E. "Os níveis da análise lingüística". In: Problemas de Lingüística Geral.São Paulo: Companhia Editora Nacional/EDUSP, 1976.

BETRÁN, R. R. e DELGADO, R.G. "La formación de formadores en el espíritu de tolerancia lingüística, cultural y metodologia". In: Revista Brasileira de Lingüística. VOL. 9, Ano 9, São Paulo: Plêide, 1997, p. 51178.

BIDERMAN, M.T.C. Teoria lingüística - lingüística quantitativa e computacional . Rio de Janeiro: LTC, 1978. 
BLACKBURN, S. Dicionário Oxford de Filosofia. São Paulo: Jorge Zahar Editor, 1994.

BLINKSTEIN, I. Técnicas de comunicação escrita. 3. ed. São Paulo: Ática, 1986.

Cultrix/Edusp, 1983.

BOURDIEU, P. Escritos de educação. Edição organizada por Maria Alice Nogueira e Afrânio Catani. 4. ed. Petrópolis : Rio de Janeiro, 2002.

BUYSSENS, E. Semiologia e comunicação lingüística. São Paulo : Cultrix, 1972.

CHARLOT, B. Da relação com o saber- Elementos para uma teoria. Porto Alegre : Artmed, 2000.

CITELLI, A. Linguagem e persuasão. 6. ed. São Paulo : Ática, 1991.

COUTO, M. J. B.E. Psicanálise e educação - A sedução e a tarefa de educar. São Paulo : Avercamp, 2003.

COSERIU, E. Teoria Del lenguage y linguistica general. Madrid : Gredos, 1969.

COUTO, M.J.B.E. Psicanálise e educação - A sedução e a tarefa de educar.São Paulo : Avercamp, 2003.

CULLER, J. As idéias de Saussure. São Paulo : Cultrix, 1976.

DUBOIS, J. et all. Dicionário de Lingüística. 8. ed. São Paulo : Cultrix, 2001

ELLIS, M e JOHSON, C. Teaching Business English. 3. ed. Oxford: Oxford University Press, 1996.

ELLIS, R. "Second Language Acquisition". In: Oxford Introductions to Language Study. 9. ed. Oxford : Oxford University Press, 2003.

EPSTEIN, I. O Signo. 4. ed. São Paulo : Ática, 1991.

FERREIRA, A. B. H. Novo Aurélio, século XXI - O dicionário da Língua Portuguesa. $5^{a}$ impressão. São Paulo : Nova Fronteira, 1999.

FIORIN, J.L. Linguagem e ideologia. São Paulo : Ática, 1988. 
FIORIN, J. L. (org.) Introdução à lingüística 1 - Objetos teóricos. São Paulo: Contexto, 2006.

FREIRE, P. Pedagogia da autonomia: saberes necessários. 22. ed. São Paulo : Paz e Terra, 1996.

- Pedagogia da indignação - cartas pedagógicas e outros

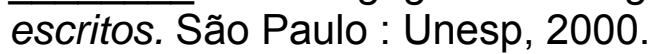

GENOUVRIER, e PEYTARD, J. Lingüística e ensino do português. Coimbra : Almedina, 1974.

GENTILHOMME, Y. O Processo Didático". In: Acta Semiótica et Lingüística. Vol 5. São Paulo : Global, 1984, p. 157-185.

GREIMAS, A. J. Semântica Estrutural. 2. ed. São Paulo : Cultrix, 1966. $\overline{\text { Fragua, } 1973 .}$

. Em torno al sentido - ensayos semióticos. Madrid : Editorial . Sobre o Sentido - ensaios semióticos. São Paulo : Vozes, 1975.

· Semiótica e Ciências Sociais. São Paulo : Cultrix, 1976a.

Semiótica do discurso Científico da Modalidade. Monografias de semiótica e lingüística. São Paulo : Difel, 1976 b.

. Introduction à L'analyse du Discours em Sciences Sociales. Paris: Hachette Universite, 1979.

1986.

. Análise do Discurso em Ciências Sociais. São Paulo : Global,

GREIMAS, A. J. e COURTÉS, J. Dicionário de Semiótica. 9. ed. São Paulo: Cultrix, 1979.

GRIGOLETTO, M. e CARMAGNANI, A.M.G. Inglês como língua estrangeira: identidade, práticas e textualidade. ed. Bilíngüe. São Paulo : Humanitas FFLCH/USP, 2001.

HARMER, J. The Practice of English Language Teaching. 3. ed. Cambridge: Longman, 2002. 
HÉNAULT, A. História concisa da semiótica. São Paulo: Parábola editorial, 2006.

HJELMSLEV, L. Prolegômenos a uma teoria da linguagem. São Paulo: Perspectiva, 1975.

JACOBS, M. A. Como não aprender inglês - erros comuns do aluno brasileiro. São Paulo, Vol. I e II, 2001.

JAKOBSON, R. Lingüística e comunicação. São Paulo : Cultrix, 1969.

KRAMSCH, C. "Language and Culture". In: Oxford Introductions to Language Study. 4 . ed. Oxford : Oxford University Press, 2003.

LA TAILLE, Y. D. Piaget, Vygotsky, Wallon: Teorias Psicogenéticas em discussão. São Paulo : Summus Editorial, 1992, p. 11-33.

LACAN, J. O Seminário - livro I. 2. ed. Rio de Janeiro: Zahar Ed.; 1983.

LOWES, R. e FRANCESCA, T. Helping Students to Learn - A guide to learner autonomy. Londres : Richmond Publishing, 1998.

LUFT, C. P. Língua e liberdade- O gigolô das palavras. Porto Alegre : L\&PM, 1985.

LURIA, A. R. O "desenvolvimento das palavras na ontogênese". In: Pensamento e Linguagem - As últimas conferências de Luria. Porto Alegre, 2001, p. 43-56.

MACHADO, I. Escola de Semiótica - A Experiência de Tártu-Moscou para o Estudo da Cultura. Ateliê Editorial, 2003.

MACMILLAN. English Dictionary for Advanced Learners of American English. 10. ed. London : Bloomsbury Publishuing PLC, 2006.

MARCUSCHI, L.A. A Formação de conceitos como questão Semântica. In: Revista Brasileira de Lingüística. VOL. 5, No 2, 1978.

MELO, L.E. (org.) Tópicos de Lingüística Aplicada. 2. ed. São Paulo : Humanitas, 1999.

MILLER, J.A. Percurso de Lacan - Uma introdução. 3. ed. Rio de Janeiro : Jorge Zahar Editor, 1992.

MILLOT, C. Freud antipedagogo. Rio de Janeiro: Jorge Zahar Editor, 2001. 
NASIO, J.D. 5 lições sobre a teoria de Jacques Lacan. Rio de Janeiro: Jorge Zahar Editor, 1993.

OLIVEIRA,M.O. Vygotsky - Aprendizagem e desenvolvimento. Um processo sócio-histórico. 4 ed. São Paulo : Scipione, 2002.

ORLANDI, E.P. A linguagem e seu funcionamento: As formas do discurso. 4. ed. Campinas : Pontes, 1996.

PALOMO, S. M. S. Análise Contrastiva do Sistema Fonológico do Armênio e do Português: Implicações Pedagógicas. 1989. 392 f. Tese (Doutorado em Lingüística Geral). Universidade de São Paulo, São Paulo.

PASSEL. F.V. Ensino de Línguas para Adultos. São Paulo : Pioneira, 1983.

PAIS, C. T. Ensaios Semiótico-lingüísticos. Petrópolis : Vozes, 1977.

- "Perspectiva e tarefas do trabalho terminológico: ensino da metalinguagem técnico-científico". In: Revista brasileira de lingüística. VOL.9, Ano 9. São Paulo: Plêiade, 1997, p. 23-41.

. Língua e literatura- Algumas reflexões sobre os modelos em lingüística, 1980, p. 89-113.

. "Conceptualisation, information, signification, production du sujet". In: Acta Semiótica et Lingüística (Asel). V. 5, São Paulo : Global, 1984, p. 41-60.

. "Sociossemiótica, semiótica da cultura e processo histórico: liberdade, civilização e desenvolvimento". In: Anais do $V$ Encontro Nacional da Anapoll. Porto Alegre, ANPOLL, 1991, p. 452-461.

. "Do processo de conceptualização, da produção lexical e da produtividade discursiva". In: IV Congresso Nacional de Lingüística e Filologia. Semântica e Lexicografia. Cadernos do CNLF, série IV, No 10, 2000, p. 105-119.

- "Atitudes e estruturas epistemológicas no processo dos estudos da linguagem". In: Revista Philologus. Rio de Janeiro, ano 8, No22, Janeiro/Abril. 2002 a, p. 7- 20.

"Conceptualização, interdiscursividade, arquitexto, arquidiscurso". In: Revista Philologus, Rio de Janeiro, Ano 8, No 23, Maio/Agosto, 2002 b. 
RAPPAPORT, C.R. e HASSAN S. E. e MOLLOY C. S. "Psicanálise Introdução à práxis Freud e Lacan”, São Paulo : E.P.U., 1992.

ROACH, P. "Phonetics". In: Oxford Introductions to Language Study. 2. ed. Oxford, Oxford University Press, 2002.

SANTAELLA, L. e Winfried, N. Semiótica. São Paulo : Experimento, 1999. . Semiótica Aplicada. São Paulo ; Thomson, 2002.

SAUSSURE, F. Curso de Lingüística Geral. 26. ed. São Paulo : Cultrix, 2004.

SCHLEIFER, R. A.J. Greimas and the nature of meaning: Linguistics, semiotics and discourse theory. Lincoln : University of Nebraska Press.

SCRIVENER, J. Learning Teaching. Oxford : Macmillian, 1994.

SINCLAIR, H. El Papel de Las Estructuras Cognitivas en la Adquisicion del lenguage. In: Fundamento Del desarrollo Del lenguage. Madrid, 1975, p. 221-237.

TAGNIN, S.O. Expressões idiomáticas e convencionais. São Paulo : Ática, 1989.

TARALLO, F. A pesquisa sociolingüística. São Paulo : Ática, 1986.

TATIT, L. "Semiótica, enunciação e polifonia". In: Revista Brasileira de Semiótica, No 11/12, setembro, São Paulo : Annablume, p. 44-60.

VILELA, M. Estruturas léxicas do português. Coimbra : Almedina, 1979.

VYGOTSKY, L.S. A formação social da mente. São Paulo: Martins Fontes, 2000.

1987. . Pensamento e linguagem. São Paulo: Martins Fontes,

WEIL, P. e TOMPALOW, R. - O corpo fala - A linguagem silenciosa da comunicação não verbal. 29. ed. Petrópolis : Vozes, 1991. 


\section{REFERÊNCIA DE MATERIAIS ESPECIAIS}

\section{FILME:}

O ENIGMA de Kaspar Hauser (Título Original: Jeder fur sich und gott gegen alle). Direção: Werner Herzog.Intérpretes:Bruno S. ; Eva Maltes; Clemens Scheitz; Walter Ladengest e outros. Estúdio: FJ Lucas. Alemanha, 1975. 1 filme (104 min), son., color., 35mm.

IKINGUT - Na Terra do Gelo (Título Original: Ikingut) Direção: Gisli Snaer Erlingsson. Intérpretes: Hjalti Runar Jonsson, Hans Tittus Nakinge, Magnus Ragnarsson e outros. Estúdio: Islandia, 2000. 1 filme (84 min.), son. , $35 \mathrm{~mm}$.

\section{VIDEO:}

Gravações de Aulas de Inglês ministradas por Paul Seligson et al. São Paulo, 2002. 1 fita de vídeo (60 min), VHS, son., color.

\section{REVISTA:}

Coleção Memória da Pedagogia, n. 4 : Paulo Freire: A Utopia do Saber/editor Manuel da Costa Pinto; colaboradores: Moacir Gadotti et al. São Paulo: Segmento-Duetto, 2005.

Coleção Memória da Psicanálise, n. 4 : A Lógica do Sujeito: Lacan/editor Manuel da Costa Pinto. São Paulo: Segmento-Duetto, 2005.

\section{REFERÊNCIA DE DOCUMENTOS ELETRÔNICOS}

CESTARO, S.A.M. O ensino de língua estrangeira: história e metodologia. Disponível em; < http:// www.hottopos.com/index.html. Acesso em 16 jun.2007

FIDALGO. A. Semiótica, a lógica da comunicação. Disponível em; < bocc.ubi.pt/pág/fidalgo-antonio-logica-cominicação.html $>$. Acesso em 28 fev. 2003. 
FORBES, J. Você é isto. Disponível em; < http:// educaoonline.pro. $\mathrm{Br}>$. Acesso em 19 jul. 2003.

GOMES, M. B. A cultura como dupla mediação social. Disponível em; < http://www.ufrnet.br/texto2.htm> . Acesso em 28 fev. 2003.

GREIMAS, A.J. The narrative frame of A.J. Greimas. Disponível em; < http:// www.swisscast.net/theory inst/greimas.htm > . Acesso em $28 \mathrm{fev}$. 2003.

Landowski,E. Foi Greimas semioticista?. Disponível em; $<$ http://www.pucsp.br/pos/cos/cps/entrevis.htm >. Acesso em $28 \mathrm{fev}$. 2003.

MRECH, L. M. Um sintoma na cultura: A falência da transmissão na relação professor-aluno. Disponível em; < http:// educaoonline.pro.br $>$. Acesso em 19 jul. 2003.

MORENTIN, J. M. Archivo de semiótica. 1. Manual de estudios semióticos. 1.1. Metodologia Disponível em; $<$ http://fortunecity.com/victorian/bacon/1244/metodologia.html > . Acesso em 27 fev. 2003. 


\section{APÊNDICE A- Needs Analysis}

\section{Needs Analysis \\ ( $1^{\circ}$ etapa)}

Sugestão para uma entrevista semi-dirigida:

1- Qual é seu objetivo com relação a língua inglesa?

2- Gosta do idioma?

3- Quantos anos você estudou inglês? Onde?

4- Poderia me explicar o método usado pelo professor?

5- Por que não continuou estudando nessas escolas (ou com o professor particular)?

6- Gostava do método?

7- O que achava de seu professor?

8- Ele Ihe orientava na maneira de estudar? Você estudava?

9- Você costuma dedicar algum tempo para estudar a língua inglesa? 0 que você estuda?

10- O que gosta de fazer no seu tempo livre?

11- O que gosta de ler?

12- Quais são suas dificuldades na língua inglesa? E necessidades?

13- Qual é a sua profissão e qual o cargo que ocupa na empresa? Em que situações você precisará utilizar a língua inglesa no seu trabalho?

14- Você precisa de um vocabulário mais específico na sua área de atuação?

15- O que você gostaria de estudar em suas aulas?

16- Que assuntos Ihe interessam?

17- O que você espera deste curso? E de seu professor? 


\section{F O L L O W U P}

Student:

Level:

Material:

Schedule:

Dear student,

Check your performance in the following itens:

\begin{tabular}{|c|c|c|c|c|c|c|}
\hline \multirow{2}{*}{$\begin{array}{c}\text { Evaluation Itens } \\
\text { (YEAR) }\end{array}$} & \multirow{2}{*}{ MONTH } & \multirow[b]{2}{*}{ MONTH } & \multirow[b]{2}{*}{ MONTH } & \multirow[b]{2}{*}{ MONTH } & \multirow[b]{2}{*}{ MONTH } & \multirow[b]{2}{*}{ MONTH } \\
\hline & & & & & & \\
\hline Reading & $A+$ & & & & & \\
\hline Writing & $\mathrm{B}+$ & & & & & \\
\hline Listening & $A+$ & & & & & \\
\hline Pronunciation & C - & & & & & \\
\hline Fluency & C - & & & & & \\
\hline Grammar & A - & & & & & \\
\hline Vocabulary & C - & & & & & \\
\hline Homework & $A+$ & & & & & \\
\hline $\begin{array}{c}\text { Written Test } \\
\text { Grade }\end{array}$ & $B+$ & & & & & \\
\hline $\begin{array}{c}\text { Oral Test } \\
\text { Grade }\end{array}$ & C - & & & & & \\
\hline $\begin{array}{l}\text { On Going } \\
\text { Process }\end{array}$ & $A+$ & & & & & \\
\hline Frequency \% & $75 \%$ & & & & & \\
\hline $\begin{array}{l}\text { General } \\
\text { Motivation }\end{array}$ & $\mathrm{B}+$ & $\begin{array}{l}\text { Needs: } \\
\text { Difficulties }\end{array}$ & & & & \\
\hline
\end{tabular}

Excellent

Good Pass

Pass

Could do Better

$$
\begin{gathered}
90-100 \%-\mathrm{A}+/- \\
75-89 \%-\mathrm{B}+/- \\
65-74 \%-\mathrm{C}+/- \\
<64 \%-\mathrm{D}+/-
\end{gathered}
$$




\section{APÊNDICE C Vocabulary Sheet}

Book:

Charpter:

Part I - Chart

\begin{tabular}{|l|l|l|l|l|l|}
\hline \multirow{2}{*}{ Nouns } & Verbs (R) or (i) & Phrsasal Verbs Adjetives Adverbs & \multicolumn{1}{l|}{ Expressions } \\
\hline & & & & & \\
\hline & & & & & \\
\hline & & & & & \\
\hline & & & & & \\
\hline & & & & & \\
\hline & & & & & \\
\hline & & & & & \\
\hline & & & & & \\
\hline & & & & & \\
\hline & & & & & \\
\hline & & & & & \\
\hline & & & & & \\
\hline & & & & & \\
\hline & & & & & \\
\hline & & & & & \\
\hline
\end{tabular}

Part II - Write about the book or article and make up sentences using the words from part I 


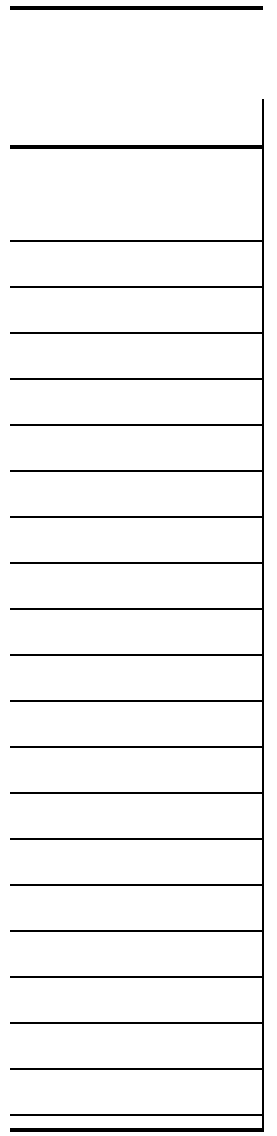


